


\title{
Effluenten van mestverwerkingsinstallaties
}

\author{
P. Hoeksma ${ }^{1}$ \\ H. Schmitt ${ }^{2}$ \\ S. de Rijk ${ }^{2}$ \\ F. de Buisonjé ${ }^{1}$ \\ P. Sefeedpari ${ }^{1}$
}

1 Wageningen Livestock Research (WLR)

2 Rijksinstituut voor Volksgezondheid en Milieu (RIVM)

Dit onderzoek is uitgevoerd door Wageningen Livestock Research (WLR) en Rijksinstituut voor Volksgezondheid en Milieu (RIVM), in opdracht van de werkgroep 'Harmonisatie lozingenbeleid mestverwerkingsinstallaties'.

Wageningen Livestock Research

Wageningen, april 2021

Rapport 1301 


\section{Samenvatting}

In dit rapport zijn de resultaten bijeengebracht van de meetcampagne die is uitgevoerd bij drie typen mestverwerkingsinstallaties (MVI's) voor varkensdrijfmest: omgekeerde osmose (OO), membraanbioreactor met ultrafiltratie (MBR-UF) en indampen, en bij biologische voorzuivering van kalvergier. Deze studie is uitgevoerd om beter zicht te krijgen op de aanwezigheid van algemene klassieke parameters en voorzorgparameters (antibiotica, (resistente) bacteriën en virussen) in het te lozen effluent en op de zuiveringsefficiëntie van technieken die als Best Beschikbare Technieken (BBT) of gelijkwaardig beschouwd kunnen worden. Daarnaast werd beoogd een referentieniveau vast te leggen voor de voorzorgparameters voor de BBT, indicatieve waarden voor de voorzorgparameters aan te geven om alternatieve technieken op gelijkwaardigheid te kunnen beoordelen, en parameters te selecteren die kunnen dienen als indicator voor het monitoren van de effectiviteit van de toegepaste zuiveringstechniek. Met de uitvoering van dit meetprogramma is een vervolgstap gezet naar harmonisatie van het lozingenbeleid voor mestverwerkingsinstallaties.

Abstract

This report presents the results of the measuring campaign that was carried out at three types of pig manure processing plants, including reverse osmosis (RO), membrane bioreactior with ultrafiltration (MBR-UF) and evaporation, and at veal manure pre-purification plants. The study was conducted to get a better view of the presence of general classic parameters and precaution parameters (antibiotics, (resistant) bacteria and viruses) in the effluents of the processing plants, and of the purification efficiency of technologies that can be considered as best available techniques (BAT) or equivalent. Additionally, the aim was to establish a reference level for precaution parameters for BAT, to present indicative values for precaution parameters to assess alternative purification techniques for equivalence, and to select indicator parameters for assessing the effectiveness of the applied technique. The implementation of this measuring campaign is a next step to harmonization of the discharge policy for effluents from manure processing plants.

Dit rapport is gratis te downloaden op https://doi.org/10.18174/543839 of op www.wur.nl/livestock-research (onder Wageningen Livestock Research publicaties).

\section{(cc) BY-NC}

Dit werk valt onder een Creative Commons Naamsvermelding-Niet Commercieel 4.0 Internationaallicentie.

(C) Wageningen Livestock Research, onderdeel van Stichting Wageningen Research, 2021

De gebruiker mag het werk kopiëren, verspreiden en doorgeven en afgeleide werken maken. Materiaal van derden waarvan in het werk gebruik is gemaakt en waarop intellectuele eigendomsrechten berusten, mogen niet zonder voorafgaande toestemming van derden gebruikt worden. De gebruiker dient bij het werk de door de maker of de licentiegever aangegeven naam te vermelden, maar niet zodanig dat de indruk gewekt wordt dat zij daarmee instemmen met het werk van de gebruiker of het gebruik van het werk. De gebruiker mag het werk niet voor commerciële doeleinden gebruiken.

Wageningen Livestock Research aanvaardt geen aansprakelijkheid voor eventuele schade voortvloeiend uit het gebruik van de resultaten van dit onderzoek of de toepassing van de adviezen.

Wageningen Livestock Research is NEN-EN-ISO 9001:2015 gecertificeerd.

Op al onze onderzoeksopdrachten zijn de Algemene Voorwaarden van de Animal Sciences Group van toepassing. Deze zijn gedeponeerd bij de Arrondissementsrechtbank Zwolle. 


\section{Inhoud}

\begin{tabular}{lr} 
Voorwoord & $\mathbf{5}$ \\
\hline
\end{tabular}

$\begin{array}{lr}\text { Samenvatting } & 7\end{array}$

$\begin{array}{lr}\text { Summary } & 11\end{array}$

$\begin{array}{lr}1 & 15\end{array}$

1.1 Achtergrond $\quad 15$

1.2 Doel 15

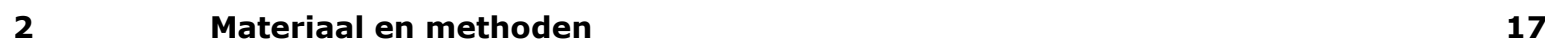

$\begin{array}{lll}2.1 & \text { Onderzochte MVI's } & 17\end{array}$

$\begin{array}{ll}2.1 .1 \text { Omgekeerde osmose } & 17\end{array}$

2.1.2 Membraanbioreactor + ultrafiltratie 18

2.1.3 Biologische voorzuivering klavergier $\quad 19$

2.1.4 Indampen 19

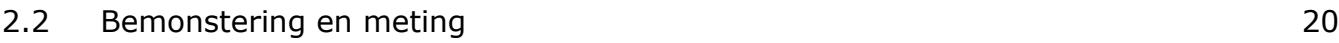

$\begin{array}{lll}2.3 & \text { Parameters } & 20\end{array}$

2.4 Analyse methoden $\quad 21$

2.4.1 Chemische parameters $\quad 21$

$\begin{array}{ll}2.4 .2 \text { Micro-organismen } & 25\end{array}$

$\begin{array}{lll}2.5 & \text { Dataverwerking } & 27\end{array}$

$\begin{array}{llr}3 & \text { Resultaten } & \mathbf{2 8}\end{array}$

3.1 Samenstelling van de ingangsmaterialen van MVI's 29

3.2 Samenstelling van effluenten van MVI's 38

$\begin{array}{lll}3.3 & \text { Samenstelling van processtromen OO } & 49\end{array}$

3.4 Samenstelling van processtromen MBR-UF 58

3.5 Samenstelling van processtromen Biologische voorzuivering van kalvergier 65

3.6 Samenstelling van processtromen Indampen 73

$\begin{array}{lll}3.7 & \text { Hormoonstoffen in processtromen } & 80\end{array}$

4

\section{Correlatie tussen parameters}

5

\section{Discussie}

$\begin{array}{lll}5.1 & \text { Algemeen } & 85\end{array}$

$\begin{array}{lll}5.2 & \text { Referentieniveaus } & 85\end{array}$

$\begin{array}{lll}5.3 & \text { Indicatieve waarden } & 88\end{array}$

$\begin{array}{lll}5.4 & \text { Indicatoren } & 88\end{array}$

$\begin{array}{lr}\text { Literatuur } & 90\end{array}$

$\begin{array}{lr}\text { Bijlage } 1 & 91\end{array}$

$\begin{array}{lr}\text { Addendum } & 107\end{array}$ 


\section{Voorwoord}

In dit rapport zijn de resultaten bijeengebracht van de meetcampagne die is uitgevoerd om beter zicht te krijgen op de aanwezigheid van algemene parameters en voorzorgparameters (antibiotica, (resistente) bacteriën en virussen) in het te lozen effluent van mestverwerkingsinstallaties en op de zuiveringsefficiëntie van technieken die als Best Beschikbare Technieken (BBT) of gelijkwaardig beschouwd kunnen worden.

Hiermee wordt invulling gegeven aan kennisleemtes die zijn geformuleerd in 'Achtergrond-document vergunningenbeleid voor lozingen van afvalwater uit mestverwerkingsinstallaties' dat in 2016 is opgesteld in het kader van harmonisatie van het lozingenbeleid voor mestverwerkingsinstallaties.

Het meetprogramma is uitgevoerd door Wageningen Livestock Research (WLR) en Rijksinstituut voor Volksgezondheid en Milieu (RIVM) in opdracht van de werkgroep 'Harmonisatie lozingenbeleid mestverwerkingsinstallaties'.

De werkgroep is als volgt samengesteld:

\begin{tabular}{|c|c|}
\hline Waterschap De Dommel & Minke Lagerwerf \\
\hline Waterschap Aa en Maas & Wim van der Hulst en Anne Wim Vonk \\
\hline Waterschap Vechtstromen & Renske Dortland-Grijpma \\
\hline Waterschap Vallei en Veluwe & Richard van Hoorn \\
\hline Waterschap Limburg & Kay Bouts \\
\hline Waterschap Rijn en IJssel & Maaike Ros en Marga Limbeek \\
\hline Provincie Brabant & Pascal Godrie \\
\hline Provincie Gelderland & Lucas van Eijsden \\
\hline Cumela & Hans Verkerk \\
\hline LTO & Michael van der Schoot \\
\hline NCM & Jan Roefs \\
\hline WUR & Oscar Schoumans/Inge Regelink \\
\hline Ministerie LNV & Harm Smit \\
\hline Ministerie IenW & Wilbert van Zeventer \\
\hline RWS WNZ & David Vroon \\
\hline RWS WVL & Gerard Rijs en Sandra Plette \\
\hline
\end{tabular}

Sandra, Gerard en David waren nauw betrokken bij de voorbereiding en uitvoering van het meetprogramma en leverden een waardevolle bijdrage aan deze rapportage, waarvoor dank.

Dank gaat ook uit naar de eigenaren en operateurs van de mestverwerkingsinstallaties waar de bemonsteringen hebben plaatsgevonden. Zonder hun welwillende medewerking had het meetprogramma niet uitgevoerd kunnen worden.

De auteurs 


\section{Samenvatting}

Het doel van dit onderzoek was door metingen aan mestverwerkingsinstallaties (MVI's) vast te stellen a) in welke mate nutriënten, toxische stoffen en pathogenen aanwezig zijn in te lozen effluent, en b) om een beter beeld te krijgen van de zuiveringsefficiëntie voor deze parameters bij toepassing van BBT (Best Beschikbare Techniek, hier omgekeerde osmose), alsmede c) van technieken die in potentie gelijkwaardig zijn. Voor nutriënten, toxische stoffen en pathogenen werden zowel voorzorgparameters als algemene parameters onderzocht. Dit onderzoek werd uitgevoerd in opdracht van de werkgroep 'Harmonisatie lozingenbeleid mestverwerkingsinstallaties', en uitgevoerd door WLR in samenwerking met RIVM.

Daarnaast werd beoogd een referentieniveau vast te leggen voor de voorzorgparameters voor BBT, d.w.z. indicatieve waarden voor de voorzorgparameters aan te geven om alternatieve technieken op gelijkwaardigheid te kunnen beoordelen, en parameters te selecteren die kunnen dienen als indicator voor het monitoren van de effectiviteit van de toegepaste zuiveringstechniek.

Met de uitvoering van dit meetprogramma is een vervolgstap gezet naar harmonisatie van het lozingenbeleid voor mestverwerkingsinstallaties.

\section{Installaties en ingangsmateriaal}

De metingen werden uitgevoerd bij drie typen MVI's voor varkensdrijfmest die gebruik maken van technieken die het effluent voldoende kunnen zuiveren, voor wat betreft algemene chemische parameters en voorzorgparameters, of die dat naar verwachting kunnen. Naast omgekeerde osmose (OO) waren dit een membraanbioreactor met ultrafiltratie (MBR-UF) en indampen. Verder was in het meetprogramma biologische voorzuivering van kalvergier opgenomen. Onderstaande tabel geeft een overzicht van de MVI's en de processtromen waaraan is gemeten.

\begin{tabular}{llll} 
OO (3-traps) & MBR-UF & Biologische & Indampen \\
$(n=2)$ & $(n=1)$ & $\begin{array}{l}\text { voorzuivering kalvergier } \\
(n=2)\end{array}$ & Digestaat co-vergisting \\
\hline Varkensdrijfmest & Varkensdrijfmest & Kalvergier & Invoer indamper \\
\hline Invoer OO & Invoer MBR & Invoer biologie & \\
\hline Concentraat OO & Invoer UF & & Effluent 1 en 2 \\
\hline $\begin{array}{l}\text { Effluent } \\
(=\text { permeaat OO na IW*) }\end{array}$ & $\begin{array}{l}\text { Effluent } \\
(=\text { afvoer UF })\end{array}$ & $\begin{array}{l}\text { Effluent } \\
(=\text { afvoer naar RWZI) }\end{array}$ & (= spuiwater vóór en na OO/IW) \\
\hline IW = ionenwisselaar & & &
\end{tabular}

De metingen waren gericht op algemene chemische parameters (zoals primaire en secundaire nutriënten, BZV, CZV en onopgeloste stoffen), zware metalen (waaronder koper, zink, lood en kwik) en de voorzorgparameters antibiotica (behorend tot tetracyclines, macroliden, sulfonamiden en chinolonen), micro-organismen en hormoonstoffen. De gemeten micro-organismen omvatten de bacteriën $E$. coli, enterokokken, sporen van sulfiet-reducerende Clostridia, sporen van Clostridium difficile en Campylobacter spp., de antibioticaresistente bacteriën ESBL- $E$. coli en MRSA (Methicilline resistente Staphylococcus aureus), alsook de virussen somatische colifagen en het Hepatitis E-virus.

Door meerdere keren te meten in de ingaande mest en in de processtromen werd een beeld verkregen van de verwijderingsefficiëntie van de belangrijkste processtappen voor deze parameters en van de aanwezigheid van deze parameters in de effluenten van de 4 typen MVI's.

Van MBR-UF en indampen kon slechts een beperkt aantal meetdata worden verzameld omdat van beide in Nederland slechts één installatie operationeel was. Van $\mathrm{OO}$ en biologische voorzuivering van kalvergier werden bij twee installaties meetdata verzameld.

De meetresultaten wijzen uit dat de ingaande varkensmest van de installaties met $\mathrm{OO}$ en MBR-UF en de ingaande kalvergier van de biologische voorzuivering op basis van de gehalten aan algemene parameters representatief waren voor deze mestsoorten. In de varkensmest werden zware metalen gemeten met de hoogste concentraties voor zink, koper, barium en nikkel. De antibiotica die het 
meest in de varkensmest werden aangetroffen waren oxytetracycline, doxycycline, sulfadiazine en flumequine, wat de verwachting is conform de gebruikte hoeveelheden van deze middelen in de varkenshouderij. De concentraties aan micro-organismen in de varkensmest waren vergelijkbaar met die in eerdere studies zijn gevonden.

De ingaande kalvergier van de biologische voorzuivering bevatte in vergelijking met de varkensmest lagere gehalten aan stikstof en fosfor. In kalvergier werden ongeveer dezelfde gehalten aan zware metalen gemeten als in varkensmest en werden dezelfde antibiotica aangetroffen, zij het in hogere concentraties. De concentraties enterokokken en ESBL-E. coli waren hoger en sporen van Clostridia lager in kalvergier dan in varkensmest.

Het ingangsmateriaal van de installatie met indampen bestond uit digestaat uit een co-vergister met varkensmest en bijproducten als substraat. Het digestaat bevatte hogere gehalten aan stikstof en fosfor dan de ingaande varkensmest van OO en MBR-UF. De gehalten aan zware metalen, antibiotica en micro-organismen in het digestaat waren vergelijkbaar met die in varkensmest. In het ingangsmateriaal van alle MVI's werden hormoonstoffen (wel of niet van natuurlijke oorsprong) aangetroffen.

\section{Processtappen en effectiviteit tussenstappen}

De eerste stap in de beschouwde verwerkingsprocessen bestond uit scheiding van de ruwe mest in een dikke en een dunne fractie. Bij OO, MBR-UF en indampen vond de scheiding plaats met een zeefbandpers, bij biologische voorzuivering met een decanteercentrifuge.

Een zeefbandpers blijkt zeer effectief voor de verwijdering van niet-opgeloste algemene parameters, zware metalen, antibiotica en hormoonstoffen. Deze stoffen komen in de dikke fractie terecht. Een zeefbandpers is minder effectief voor het verwijderen van micro-organismen.

Scheiding met een decanteercentrifuge met kalvergier als ingaande mest toonde voor vrijwel alle gemeten chemische parameters een lager verwijderingsrendement dan scheiding met een zeefbandpers met varkensmest of digestaat als ingangsmateriaal.

Bij OO werd na de scheiding de dunne fractie verder behandeld d.m.v. dissolved air flotation (DAF) alvorens omgekeerde osmose als laatste processtap werd toegepast. Het effect van de DAFbehandeling is niet gemeten.

Bij MBR-UF werd na scheiding de dunne fractie biologisch behandeld volgens het actief-slibproces met nitrificatie en denitrificatie waarna ultrafiltratie als laatste processtap werd toegepast.

Bij biologische voorzuivering van kalvergier werd de dunne fractie eveneens volgens het actiefslibproces met nitrificatie en denitrificatie behandeld met als laatste processtap slibbezinking. Bij indampen werd na scheiding de dunne fractie ingedampt met spuiwater als restvloeistof. In de loop van de meetcampagne werd omgekeerde osmose als laatste processtap toegevoegd.

Biologische behandeling van de dunne mestfractie laat een wisselend effect zien op de gehalten van de gemeten parameters. Bij MBR-UF is na de biologische behandeling het biologisch zuurstofverbruik (BZV) met de helft en het ammoniumgehalte met meer dan 95\% afgenomen. Het gemeten effect op zware metalen, antibiotica, hormoonstoffen en micro-organismen door de biologische behandeling was echter gering, met als kanttekening dat hier slechts enkele meetwaarden aan ten grondslag liggen. De verwijdering van deze stoffen vond met name plaats door middel van slib-water scheiding in de nageschakelde membraanfiltratie.

Biologische behandeling gevolgd door slibbezinking van de dunne fractie van kalvergier blijkt wat algemene parameters betreft effectief voor het verwijderen van het biologisch en chemisch zuurstofverbruik, stikstof en fosfor. Ook vindt effectieve verwijdering plaats van zware metalen en antibiotica. De concentratie aan pathogenen, met uitzondering van sporen van Clostridia, neemt door de biologische behandeling en slibbezinking met log 2-3 (of te wel 99-99.9\%) af - dit is duidelijk minder dan de afname in behandeling door OO en UF. De verwijderde stoffen komen in het slib terecht.

\section{Vergelijking van effluenten}

De effluenten van 00 en indampen (na OO) zijn wat betreft algemene parameters en voorzorgparameters gelijkwaardig, zoals verwacht mocht worden. In de OO-effluenten zijn lage gehalten van de meeste algemene parameters gemeten en zijn enkele zware metalen en antibiotica incidenteel aangetroffen. Ook werden bacteriën en virussen in zeer lage concentraties gemeten. In het effluent van indampen na OO werden hormoonstoffen slechts in lage concentraties aangetroffen. 
Doordat detectiegrenzen van de meeste zware metalen hoger waren dan de normwaarden voor oppervlaktewater (JG-MKN = jaargemiddelde concentratie voor langdurige blootstelling), was toetsing van de effluenten aan deze normwaarden niet goed mogelijk.

Het effluent van MBR-UF bevat hogere gehalten aan algemene parameters, zware metalen en hogere concentraties bacteriën en virussen dan effluent van 00 . Dit was te verwachten gezien het verschil in poriegrootte tussen een UF-membraan $(2-100 \mathrm{~nm})$ en een OO-membraan $(<1 \mathrm{~nm})$. Wat antibiotica betreft zijn deze effluenten gelijkwaardig. Hormoonstoffen werden in zeer lage concentraties in effluent van MBR-UF aangetroffen.

De gehalten van enkele antibiotica, te weten oxytetracycline, doxycycline en tilmicosine, die in de effluenten van $\mathrm{OO}$ en MBR-UF zijn aangetroffen lagen boven de PNEC-waarden (= Predicted No Effect Concentrations) voor oppervlaktewater.

Het effluent van biologische voorzuivering van kalvergier wordt gekenmerkt door hogere gehalten aan vrijwel alle gemeten parameters in vergelijking met de effluenten van OO en MBR-UF en is daarom niet geschikt om zonder verdere zuivering op oppervlaktewater geloosd te worden.

De kwaliteit van de effluenten van de 4 beschouwde MVI's kan samengevat als volgt worden weergegeven ( 0 geeft aan dat de groep stoffen niet is aangetroffen, + dat de groep stoffen is aangetroffen, ++ en +++ in steeds hogere concentraties):

\begin{tabular}{|c|c|c|c|c|}
\hline & 00 & MBR-UF & $\begin{array}{c}\text { Biologische } \\
\text { voorzuivering }\end{array}$ & $\begin{array}{c}\text { Indampen } \\
\text { (na 00) }\end{array}$ \\
\hline Algemene parameters & + & ++ & +++ & + \\
\hline Zware metalen & 0 & + & + & 0 \\
\hline Antibiotica & 0 & 0 & ++ & 0 \\
\hline Micro-organismen & + & ++ & +++ & + \\
\hline Hormoonstoffen & 0 & + & + & 0 \\
\hline
\end{tabular}

Over het algemeen is de kwaliteit van het effluent na OO beter dan na MBR-UF, zowel wat betreft de algemene parameters als zware metalen, pathogenen en hormoonstoffen. De verschillen zijn relatief klein en daarom kunnen beide typen zuiveringstechnieken als BBT worden aangemerkt. Voor beide technieken zal het bevoegd gezag op basis van de lozingssituatie (o.a. middels een immissietoets) beoordelen of en welke aanvullende behandeling vereist is om tot een aanvaardbare kwaliteit van het te lozen water te komen.

Aanbeveling: analyse van zware metalen in de effluenten met een analysemethode met een lagere detectiegrens zodat toetsing van effluenten aan normwaarden voor zware metalen in oppervlaktewater mogelijk wordt.

\section{Referentieniveaus}

Een referentieniveau wordt in het kader van dit onderzoek gedefinieerd als een waarde van indicatorparameters aan de hand waarvan kan worden beoordeeld of BBT op de juiste wijze op MVI-afvalwater is toegepast alvorens tot lozing van effluent wordt overgegaan. Referentieniveaus moeten beschouwd worden als prestatiekenmerken voor BBT en gelden niet als richtgetallen voor het vaststellen van grenswaarden in een lozingsvergunning.

De uitgevoerde meetcampagne heeft meetgegevens opgeleverd op basis waarvan een eerste indicatief beeld is verkregen van de prestatiekenmerken voor de BBT voor algemene chemische parameters, zware metalen, antibiotica en micro-organismen. De verkregen dataset is echter ontoereikend om daadwerkelijk de prestatiekenmerken voor de BBT te kunnen vaststellen. Op basis van de data uit deze meetcampagne kunnen slechts indicatieve 'door de oogharen' afgeleide prestatiekenmerken worden gegeven. Voor een meer gefundeerde afleiding is een groter gegevensbestand nodig. Mogelijk kan hiervoor gebruik gemaakt worden van data die verkregen zijn uit andere onderzoeken en gegevens die beschikbaar zijn bij het bevoegd gezag over MVI-effluenten met deze BBT. 
Aanbeveling: vaststellen van de samenstelling van effluenten van BBT op basis van een grotere dataset, waarbij gebruik gemaakt wordt van meetdata uit andere onderzoeken, zodat referentieniveaus en indicatoren gefundeerd kunnen worden afgeleid.

\section{Indicatieve waarden}

Omdat de zuiveringsprestaties van OO en MBR-UF van elkaar verschillen, is het niet mogelijk om voor beide technieken dezelfde indicatieve waarden te benoemen waarop alternatieve technieken op gelijkwaardigheid beoordeeld kunnen worden. Deze toetsing dient plaats te vinden per type techniek, waarin de beoogde lozingssituatie leidend zal zijn. De hierboven genoemde indicatieve prestatiekenmerken kunnen fungeren als indicatieve waarden waaraan alternatieve technieken getoetst kunnen worden.

\section{Indicatoren}

Als indicatoren voor het monitoren van de efficiëntie van de toegepaste zuiveringstechniek voor het vrijkomende water van een MVI kunnen de volgende parameters in aanmerking komen:

- $\quad B Z V$ : verstrekt informatie over het functioneren van het biologisch zuiveringsproces en de resulterende zuurstofvraag in ontvangend oppervlaktewater;

- $\quad P$-totaal: verstrekt informatie over de P-belasting voor ontvangend oppervlaktewater;

- $\quad \mathrm{N}-\mathrm{NH}_{4}$ : wordt in de huidige praktijk van waterkwaliteitsbeheer veelal gebruikt als sleutelparameter (vanwege de toxiciteit van ongedissocieerd $\mathrm{NH}_{3}$ ) die bepalend kan zijn voor de beoordeling van de waterkwaliteit voor het ontvangende oppervlaktewater;

- Onopgeloste bestanddelen: verstrekt informatie over de conditie van en het functioneren van membranen;

- $\quad E C, \mathrm{~K}_{\text {en }} \mathrm{Cl}^{-}$: verstrekken informatie over de conditie en het functioneren van OOmembranen;

- $\quad \mathrm{Cu}$ en $\mathrm{Zn}$ : komen algemeen voor in mest en zijn representatief voor verwijdering van overige metalen;

- Oxytetracycline en doxycycline: komen algemeen voor in mest en zijn representatief voor verwijdering van overige antibiotica;

- $\quad$ E. coli en intestinale enterokokken: komen algemeen in hoge aantallen voor in mest en zijn representatief voor de verwijdering van pathogene bacteriën en antibiotica-resistente bacteriën.

- Somatische colifagen (bacteriofagen die E. coli bacteriën infecteren): Deze komen algemeen voor in mest en zijn representatief voor de verwijdering van virussen.

Uit deze lijst zouden enkele indicatoren geselecteerd kunnen worden waarmee een goed beeld te krijgen is van het functioneren van het zuiveringsproces en de kwaliteit van het effluent.

Ter ondersteuning van de keuze van mogelijke indicatoren, die zouden kunnen dienen voor het monitoren van de efficiëntie van de toegepaste zuiveringstechniek en de kwaliteit van het effluent van een MVI, is de correlatie vastgesteld tussen de gemeten parameters in de effluenten van OO, MBR-UF en indampen. Van de algemene chemische parameters vertonen kalium, onopgeloste stoffen en CZV de sterkste correlatie met andere algemene parameters in de effluenten. De correlatie met zware metalen en antibiotica kon niet worden vastgesteld wegens gebrek aan voldoende meetdata. Het is aan te bevelen de correlatie tussen algemene parameters en voorzorgparameters beter in beeld te brengen op basis van een groter aantal meetdata.

Aanbeveling: vaststellen van de samenstelling van effluenten van BBT-technieken op basis van een grotere dataset, waarbij gebruik gemaakt wordt van meetdata uit andere onderzoeken, zodat correlaties tussen parameters voldoende betrouwbaar kunnen worden vastgesteld.

De geschiktheid van indicatoren hangt echter ook af van de praktische toepasbaarheid; ze moeten relatief makkelijk en met voldoende nauwkeurigheid te meten zijn en tegen zo laag mogelijke kosten. 


\section{Summary}

The purpose of this study was to determine by measurements of manure processing plants a) to what extent nutrients, toxic substances and microorganisms are present in effluents, and b) to get a better picture of the purification efficiency for these parameters when applying BAT (best available technique, i.c. reverse osmosis) and techniques that are potentially equivalent. The measuring campaign was carried out on behalf of the working group 'Harmonization of the policy for discharge from manure processing plants' and was done by Wageningen Livestock Research in cooperation with National Institute for Public Health and the Environment (RIVM).

In addition, the aim was to establish a reference level for the precautionary parameters for BAT, to indicate indicative values for the precautionary parameters in order to assess alternative techniques for equivalence, and to select parameters that could serve as an indicator of monitoring the effectiveness of the purification technique used.

The implementation of this measurement campaign is a further step towards harmonizing the discharge policy for manure processing plants.

\section{Processing plants and input}

The measurements were carried out on three types of processing plants for pig slurry that use techniques that can sufficiently purify the effluent, from both general chemical parameters and precautionary parameters, or which are expected to be able to do so. In addition to 3-stage reverse osmosis (RO), these were a membrane bioreactor with ultrafiltration (MBR-UF) and vaporization. Furthermore, the measuring program included biological pre-purification of veal calf slurry. The table below gives an overview of the processing plants and the process flows that have been measured.

\begin{tabular}{|c|c|c|c|}
\hline $\begin{array}{l}\text { RO (3-stage) } \\
(n=2)\end{array}$ & $\begin{array}{l}\text { MBR-UF } \\
(n=1)\end{array}$ & $\begin{array}{l}\text { Biological pre-purification } \\
(n=2)\end{array}$ & $\begin{array}{l}\text { Vaporization } \\
(n=1)\end{array}$ \\
\hline Input RO & Input MBR & Input biology & Input vaporator \\
\hline $\begin{array}{l}\text { Effluent } \\
(=\text { permeate RO after iex }+ \text { ) }\end{array}$ & $\begin{array}{l}\text { Effluent } \\
\text { (= output UF) }\end{array}$ & $\begin{array}{l}\text { Effluent } \\
\text { (= discharged to municipal } \\
\text { waste water purification } \\
\text { plant) }\end{array}$ & $\begin{array}{l}\text { Effluent } 1 \text { en } 2 \\
\text { (= flushing water before and } \\
\text { after RO and iex) }\end{array}$ \\
\hline
\end{tabular}

$*$ iex $=$ ion exchange

The measurements focused on general chemical parameters (such as primary and secondary nutrients, BOD, COD and undissolved substances), heavy metals (among which copper, zinc, lead and mercury) and precautionary parameters, which were antibiotics (tetracyclines, macrolides, sulfonamides and chinolones), microorganisms and hormone substances. The measured microorganisms included the bacteria E. coli, Enterococci, traces of sulfite-reducing Clostridia, traces of Clostridium difficile and Campylobacter spp., the antibiotic resistant bacteria ESBL- E. coli and MRSA (Methicillin resistant Staphylococcus aureus), as well as the viruses somatic coliphages and Hepatitis E virus.

By measuring these parameters multiple times in the incoming manure and in the process flows, an image was obtained of the removal efficiency of the main process steps for these parameters and of the presence of these parameters in the effluents.

Only a limited number of measurement data could be collected from MBR-UF and vaporization because only one installation was operational in the Netherlands. Measurement data were collected from 00 and biological pre-purification at two plants.

The results show that the incoming pig manure from the $\mathrm{OO}$ and MBR-UF plants and the veal calf slurry of the biological pre-purification on basis of general chemical parameters levels were representative for these manure species. Heavy metals were measured in pig manure with the highest 
concentrations for zinc, copper, barium and nickel. The antibiotics most commonly found in pig manure were oxytetracycline, doxycycline, sulfadiazine and flumequine, which is expected to be consistent with the quantities of these substances used in pig farming. The concentrations of microorganisms in the pig manure were similar to those found in previous studies.

The incoming calf slurry of the biological pre-purification plant contained lower levels of nitrogen and phosphorus compared to the pig manure. In calf slurry, roughly the same levels of heavy metals were measured as in pig manure and the same antibiotics were found, albeit in higher concentrations. The entrance material of the evaporation plant consisted of digestate of a co-digester with pig manure and by-products as a substrate. The digestate contained higher levels of nitrogen and phosphorus than the incoming pig manure of RO and MBR-UF. The levels of heavy metals, antibiotics and microorganisms in the digestate were similar to those in pig manure. Hormone substances (whether or not of natural origin) were found in the input material of all processing plants.

Process steps and their effectiveness

The first step of the treatment process consisted of separating the raw manure into a solid and a liquid fraction. In RO, MBR-UF and vaporization, the separation took place with a sieve-belt press, in biological pre-purification with a decanting centrifuge. A sieve-belt press proves very effective for the removal of undissolved general parameters, heavy metals, antibiotics and hormone substances. These components end up in the solid fraction. A sieve-band press is less effective for removing biological parameters. Separation with a decanting centrifuge with calf slurry as incoming manure showed a lower removal efficiency for almost all measured chemical parameters than separation with a sieve with pig manure or digestate as input material.

In the RO plant, after the separation, the liquid fraction was further treated by means of dissolved air flotation (DAF) and filtered before RO (and ion exchange) was finally applied, leaving RO-concentrate and RO-permeate (effluent to be discharged). The effect of the DAF treatment has not been measured.

In the MBR-UF plant the liquid fraction was biologically treated according to the active sludge process with nitrification and denitrification, after which ultrafiltration was applied as the final process step, leaving UF-permeate as the effluent to be discharged.

In the biological pre-purification plant the liquid fraction of calf slurry was also treated according to the active sludge process with nitrification and denitrification. After this process sludge was separated in a settler leaving an effluent to be further treated in a municipal waste water treatment plant.

In the evaporation plant water from the liquid fraction was removed in a low temperature evaporator leaving condensed water as the effluent to be discharged. RO treatment of this effluent was added in the course of the measurement campaign.

Biological treatment of the liquid fraction shows a varying effect on the content of the measured parameters. In MBR-UF, biological oxygen demand (BOD) decreased by more than $95 \%$ after biological treatment. However, the effect of biological treatment on heavy metals, antibiotics, hormones and microorganisms was small, where noted that this observation is based on only a few data. The removal of these substances took place mostly in the final UF filtration step.

Biological treatment followed by sludge settling is effective for the removal of general parameters BOD, COD, N-total and P-total and also of heavy metals and antibiotics. The concentration of microorganisms, with the exception of spores of Clostridia, decreases with log 2-3 (or 99-99.9\%), which is significantly less than the decrease by RO and UF. The removed substances end up in the sludge.

\section{Comparison of effluents}

The effluents of RO and evaporation (after RO) are equivalent in terms of general parameters and precautionary parameters, as might be expected. Low levels of most general parameters have been measured in the RO effluents and some heavy metals and antibiotics have been found incidentally. Bacteria and viruses were also measured in very low concentrations. In the effluent of evaporation after RO, hormone substances were found in a concentration below the threshold applicable to risks to aquatic life.

Due to the fact that detection limits of most heavy metals were higher than the standards (JG-MKN = annual average concentration for long-term exposure) for surface water, the test of effluents to these standards was not quite possible. The effluent of MBR-UF contains higher levels of general parameters, heavy metals and higher concentrations of bacteria and viruses than effluent of RO. This was to be expected given the difference in pore size between a UF membrane $(2-100 \mathrm{~nm})$ and an RO 
membrane $(<1 \mathrm{~nm})$. Hormone substances were found in very low concentrations in effluent of MBRUF.

The levels of some antibiotics found in the effluents of RO and evaporation were above the PNEC (Predicted No Effect Concentrations) for surface water. In RO these were oxytetracycline and doxycycline, in vaporization this was tilmicosine. The effluent of biological pre-purification of calf slurry is characterized by higher levels on almost all measured parameters compared to the effluents of RO and MBR-UF, and is therefore not suitable for discharge on surface water without further purification. Heavy metals were barely found in the effluent of biological pre-purification.

The quality of the effluents of the 4 treatment processes can be summarized as follows ( 0 indicates that the group of substances has not been found, + that the group of substances has been found, ++ and +++ in increasing concentrations):

\begin{tabular}{|c|c|c|c|c|}
\hline & RO & MBR-UF & $\begin{array}{c}\text { Biological } \\
\text { pre- } \\
\text { purification }\end{array}$ & Evaporation \\
\hline Heavy metals & 0 & + & + & 0 \\
\hline Microorganisms & + & ++ & +++ & + \\
\hline Hormone substances & 0 & + & + & 0 \\
\hline
\end{tabular}

In general, the quality of the effluent after $\mathrm{OO}$ is better than after MBR-UF, both in terms of general parameters and heavy metals as well as microorganisms and hormone substances. The differences are relatively small and therefore both types of purification techniques can be classified as BAT. For both techniques, the competent authority will assess on the basis of the discharge situation (e.g. by means of an input test) whether and what additional treatment is required in order to achieve an acceptable quality of the water to be discharged.

Recommendation: measure heavy metals in the effluents using an analysis method with a lower detection limit to allow testing of effluents to standard values for heavy metals in surface water.

\section{Reference levels}

A reference level is defined in the context of this study as a value of indicator parameters to assess whether BAT has been applied appropriately before effluent is discharged. Reference levels should be considered as performance characteristics for BAT and should not be considered as target values for setting standards in a discharge permit. The measurement campaign has produced data on the basis of which an indicative picture was obtained of the performance characteristics for BAT for general chemical parameters, heavy metals, antibiotics and micro-organisms. However, the dataset obtained was insufficient to actually establish the performance characteristics for BAT. Based on the data from this measurement campaign, only indicative performance characteristics can be given. A more informed distraction requires a larger database. Data obtained from other studies and data available from the competent authority on manure processing plant effluents may be used for this purpose.

Recommendation: determine the composition of BAT effluents based on a larger dataset, using measurement data from other studies to deduce reference levels and indicators

\section{Indicative values}

Because the purification performance of RO and MBR-UF differ from each other, it is not possible to identify the same indicative values for both techniques on which alternative techniques can be assessed for equivalence. This review should be carried out by the technique, in which the intended discharge situation will be leading. The above-mentioned indicative performance characteristics can act as indicative values to which alternative techniques can be tested. 


\section{Indicators}

As indicators for monitoring the efficiency of the purification technique used for the effluent of a manure processing plant, the following parameters may be considered:

- $B O D$ : provides information on the functioning of the biological purification process and the resulting oxygen demand in the receiving surface water;

- $\quad$-total: provides information on the impact of $\mathrm{P}$ for the receiving surface water;

- $\quad \mathrm{N}-\mathrm{NH}_{4}$ : is currently used as key parameter in water quality management which can be decisive for quality assessment of the receiving surface water;

- Non-soluble substances: provides information on the condition and functioning of membranes;

- $\quad E C, K$ and $\mathrm{Cl}^{-}$: provide information on the condition and functioning of RO membranes;

- $\quad \mathrm{Cu}$ and $\mathrm{Zn}$ : are generally present in manure and are representative for removal of other metals;

- Oxytetracycline and doxycycline: are generally present in (solid fraction of) manure and are representative for removal of other antibiotics;

- $\quad$ E. coli and intestinal enterococci: are generally present in manure and are representative for removal of bacteria and antibiotic resistant bacteria;

- Somatic coliphages (bacteriophages that infect E. coli): are generally present in manure and are representative for removal of viruses.

From this list, some indicators could be selected to get a good picture of the functioning of the purification process and the quality of the effluent.

In order to support the choice of possible indicators, which could be used to monitor the efficiency of the purification technique applied and the quality of the effluent of a manure processing plant, the correlation has been established between the measured parameters in the effluents of RO, MBR-UF and evaporation. Of the general chemical parameters, potassium, undissolved substances and COD show the strongest correlation with other general parameters. The correlation with heavy metals, antibiotics and microorganisms could not be established due to lack of sufficient measurement data. It is recommended to better identify the correlation between general parameters and precautionary parameters based on a larger number of data.

Recommendation: determine the composition of effluents from BAT techniques based on a larger dataset, using data from other studies, so correlations between general parameters and precautionary parameters can be reliably established

The suitability of indicators also depends on the practical applicability; they should be relatively easy to measure, with sufficient accuracy and at the lowest possible cost. 


\section{$1 \quad$ Inleiding}

\section{$1.1 \quad$ Achtergrond}

Sinds 2014 zijn veeteeltbedrijven met een mestoverschot verplicht om een deel van het mestoverschot te (laten) verwerken. De verplichte mestverwerking heeft geresulteerd in een toename van de mestverwerkingscapaciteit en initiatieven voor nieuwe mestverwerkingsinstallaties (MVI's). Dit heeft geleid tot meer aanvragen voor lozingsvergunningen op oppervlaktewater of het gemeentelijk rioolstelsel van restwater dat vrijkomt uit MVI's. Dit te lozen water ontstaat bij het type mestverwerking waar de mest (al dan niet na (co-)vergisting) wordt gescheiden in een dikke en dunne fractie, waarna de dunne fractie vervolgens wordt gezuiverd tot een loosbare waterstroom. Afvoer van deze waterstroom kan plaatsvinden direct op oppervlaktewater of op het vuilwaterriool van gemeenten. Directe lozing zal aan scherpere lozingseisen moeten voldoen dan indirecte lozing omdat de vuilwaterriolering is aangesloten op een rioolwaterzuiveringsinstallatie in beheer bij een waterschap.

Om te komen tot loosbaar water is het door de hoge concentraties aan stoffen in dierlijke mest vereist gebruik te maken van geavanceerde zuiveringstechnieken of combinaties daarvan. Per stof/parameter zijn verschillende zuiveringstechnieken mogelijk, maar vooralsnog zuiveren alleen combinaties met omgekeerde osmose (OO) het water vergaand. Dit geldt zowel voor de klassieke parameters als voor zogenaamde voorzorgparameters, zoals pathogenen, waaronder antibioticaresistente bacteriën, en medicijnresten. Op basis van 'expert-judgement' is in 2012 bepaald dat omgekeerde osmose vooralsnog de (enige) techniek is die voorzorgparameters volledig uit het vrijkomende water bij mestverwerking kan verwijderen. $\mathrm{Er}$ is een voorstel om omgekeerde osmose (OO) voor te schrijven als Best Beschikbare Techniek (BBT).

De keuze om OO als BBT aan te merken bij MVI-lozingen op oppervlaktewater is voortgekomen uit de voorzorg om gezondheidsrisico's ten gevolge van de verspreiding van pathogenen, waaronder virussen en antibioticaresistente bacteriën in het watermilieu zo veel mogelijk te beperken en de aquatische leefgemeenschappen te beschermen. Van de membraanfiltratietechnieken houdt 00 deze voorzorgparameters het meest effectief tegen met als resultaat een 'schoon' op oppervlaktewater loosbaar effluent en een concentraatstroom met de achtergehouden stoffen. Door voortschrijdend inzicht is nu de verwachting dat naast 00 ook andere technieken zoals indampen en de combinatie membraanbioreactor-ultrafiltratie (MBR-UF) de voorzorgparameters vergaand uit het restwater kunnen verwijderen waardoor de gezondheidsrisico's tot een minimum worden beperkt.

Er zijn wat betreft de voorzorgparameters nog (te) weinig betrouwbare meetgegevens beschikbaar van de zuiveringsefficiëntie door OO, MBR-UF en indampen bij MVI-afvalwater en de uiteindelijk resulterende concentraties in het te lozen water. In het 'Achtergronddocument vergunningenbeleid voor lozingen van afvalwater uit mestverwerkingsinstallaties' wordt aanbevolen deze kennisleemte op te vullen (Voorthuizen et al , 2016). Tevens bestaat er geen goed beeld van de zuiveringsprestaties voor de voorzorgparameters bij kalvergierbewerking, die bestaat uit biologische voorzuivering van de dunne fractie in een kalvergierbewerkingsinstallatie (KGBI) gevolgd door een nabehandeling in een rioolwaterzuiveringsinstallatie (RWZI). In dit rapport worden alleen de prestaties van de biologische voorzuivering weergegeven.

\subsection{Doel}

Van september 2019 tot juni 2020 is een meetprogramma uitgevoerd met als oogmerk vast te stellen of voorzorgparameters en algemene parameters in milieubezwaarlijke mate in te lozen water uit MVI's aanwezig zijn en een beter beeld te krijgen van de zuiveringsefficiëntie van deze parameters bij toepassing van OO, MBR-UF en indampen, en bij de huidige kalvergierverwerking. 
Daarnaast beoogt de werkgroep 'Harmonisatie lozingenbeleid mestverwerkingsinstallaties' met deze meetcampagne het volgende te bereiken:

1. Het vastleggen van referentieniveaus voor de voorzorgparameters aanwezig in effluenten van MVI's bij technieken die in aanmerking komen voor BBT;

2. Het benoemen van indicatieve waarden voor de voorzorgparameters om alternatieve technieken op gelijkwaardigheid te kunnen beoordelen;

3. Een selectie te maken van mogelijke parameters die als indicator kunnen dienen voor het eenvoudig/betaalbaar monitoren van de efficiëntie van de toegepaste zuiveringstechniek voor het vrijkomende water van een MVI. 


\section{Materiaal en methoden}

\section{$2.1 \quad$ Onderzochte MVI's}

Om een goed beeld te krijgen van de zuiveringsefficiëntie van algemene parameters en voorzorgparameters bij toepassing van OO, MBR-UF en indampen werden metingen gedaan aan de behandelingstechnieken die representatief zijn voor de huidige mestverwerkingspraktijk en waarbij vooral varkensdrijfmest was betrokken. Daarnaast werden metingen uitgevoerd aan kalvergierbewerkingsinstallaties. Teneinde de zuiveringsefficiëntie van de verschillende behandelingstechnieken te kunnen vaststellen, werden metingen gedaan aan de belangrijkste vloeibare processtromen. Vaste fracties bleven buiten beschouwing omdat die uit waterkwaliteitsoogpunt niet van belang zijn. Tabel $1 \mathrm{geeft}$ de typen MVI's en de deelstromen per type installatie die werden bemonsterd en geanalyseerd op algemene en voorzorgparameters. Bij de opzet van de meetcampagne werd uitgegaan van twee installaties per type MVI. Echter, van de typen MBRUF en indampen was slechts één representatieve full scale installatie operationeel waarbij de metingen konden worden uitgevoerd.

Tabel 1 De MVI's en de processtromen waaraan is gemeten.

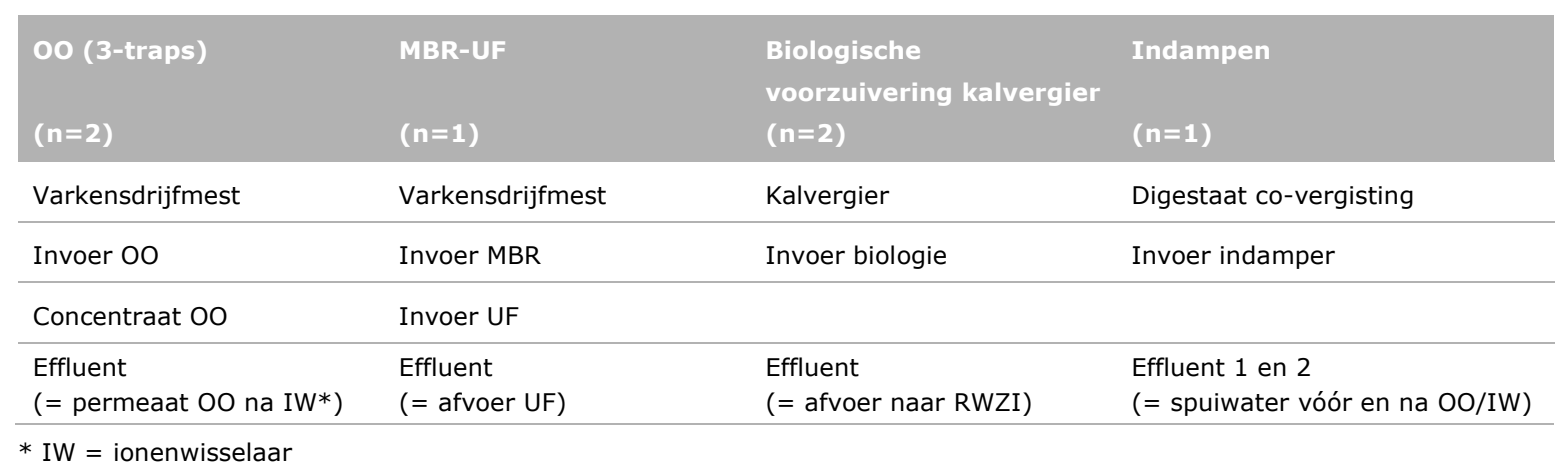

\subsubsection{Omgekeerde osmose}

Omgekeerde osmose $(\mathrm{OO})$ wordt bij mestverwerking als laatste behandelingsstap toegepast om dunne mestfracties te zuiveren tot op oppervlaktewater loosbaar water en een geconcentreerde zoutoplossing, het z.g. mineralenconcentraat. Bij de verwerking van varkensmest wordt vaak een meertraps OO-systeem toegepast teneinde een hoge afscheidingsgraad van permeaat te bereiken. Voor lozingen op oppervlaktewater wordt doorgaans een ionenwisselaar (IW) nageschakeld. Het behandelingsproces begint met mechanische scheiding van de ruwe mest in een vaste en een vloeibare dunne fractie (zie Figuur 2.1). Hierbij wordt gebruik gemaakt van een zeefbandpers (zbp) onder toevoeging van een vlokmiddel in de vorm van een organisch polymeer (poly-acrylamide). De dunne mestfractie dient verder geschikt gemaakt te worden voor oo: vaste organische en anorganische delen dienen zoveel mogelijk te worden verwijderd om vervuiling en beschadiging van de OO-membranen te voorkomen. Dissolved air flotation (DAF) is de techniek die hiervoor wordt toegepast. Hierbij worden zwevende mestdeeltjes aan fijne luchtbelletjes naar de oppervlakte gedreven en vervolgens afgeschraapt. Mechanische scheiding en DAF worden in de praktijk ook in omgekeerde volgorde toegepast. Om de kans op vervuiling en beschadiging van de membranen verder te verkleinen zijn vóór de $\mathrm{OO}$ een of twee papierfilters $(40 \mu \mathrm{m})$ geplaatst. Ondanks deze grondige voorzuivering is regelmatig, vaak dagelijks, reinigen van de membranen met zuur en loog noodzakelijk. De massaverhouding tussen de eindproducten dikke fractie, concentraat oO en effluent (permeaat OO) bedraagt typisch ca. 20:30:50. 


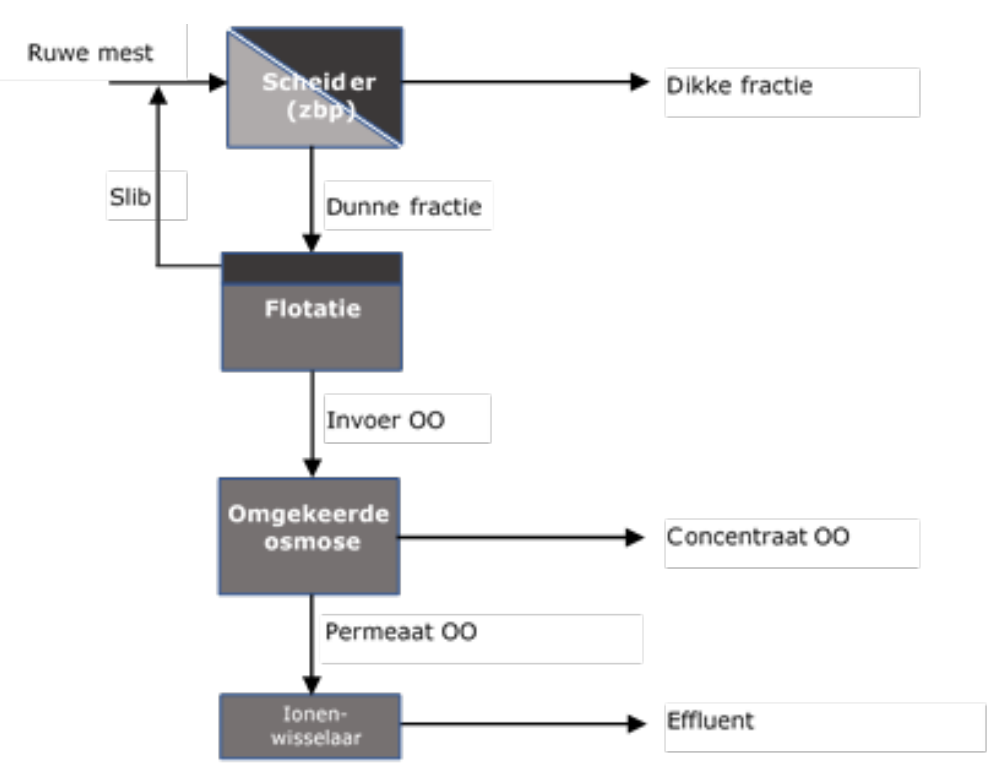

Figuur 2.1 Schematische weergave van het mestverwerkingsproces met omgekeerde osmose.

\subsubsection{Membraanbioreactor + ultrafiltratie}

Een membraanbioreactor is een koppeling van een biologisch actief slib systeem, vergelijkbaar met de voorzuivering van kalvergier met de processen nitrificatie en denitrificatie, aan een vorm van membraanfiltratie. Verschillende filtratietechnieken zijn mogelijk zoals microfiltratie en ultrafiltratie. Een membraanbioreactor in combinatie met ultrafiltratie (MBR-UF) wordt bij slechts enkele mestverwerkingsinstallaties in Nederland toegepast. MBR-UF heeft ten opzichte van OO als voordeel dat er geen resterende concentraatstroom is en de investeringskosten (mogelijk) lager zijn. Ook de energiebehoefte is geringer, vooral omdat de druk waarbij wordt gewerkt bij UF (2-10 bar) aanmerkelijk lager is dan bij OO (10-100 bar). Een UF-membraan (max. 0,1 $\mu \mathrm{m}$ ) is minder fijnmazig dan een OO-membraan (max. $1 \mathrm{~nm}$ ). Een MBR-UF zou, eventueel in combinatie met aanvullende zuiveringstechnieken, net als bij OO een op oppervlaktewater loosbaar effluent op kunnen leveren. De installatie waaraan in het kader van deze studie metingen zijn gedaan was voorzien van een submerged UF filter, zoals schematisch weergegeven in Figuur 2.2.

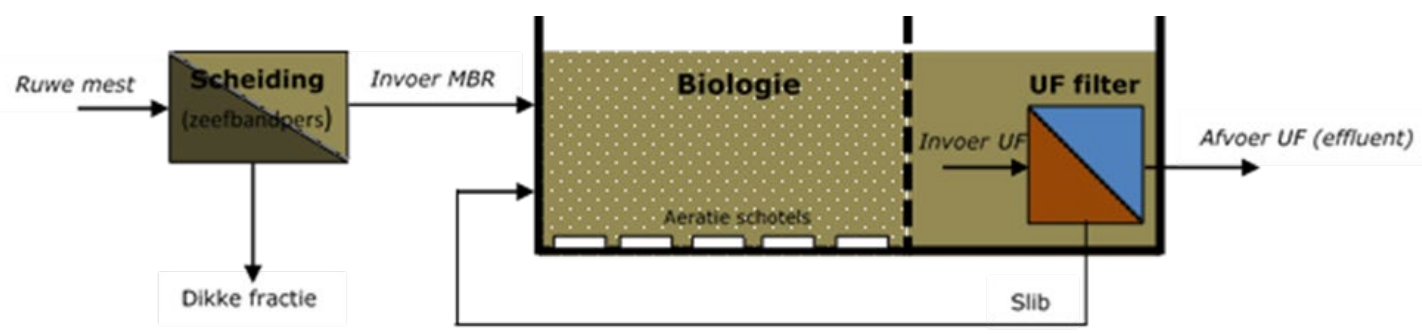

Figuur 2.2 Schematische weergave van het mestverwerkingsproces met MBR-UF. 


\subsubsection{Biologische voorzuivering klavergier}

In een kalvergierbehandelingsinstallatie (KGBI) wordt de dunne fractie, die vrijkomt na mechanische scheiding, verder behandeld waarbij gebruik wordt gemaakt van biologische behandeling met de processen van nitrificatie en denitrificatie. Met de toename van het aantal kalveren dat ruwvoer krijgt verstrekt is het organische stofgehalte in kalvergier zodanig toegenomen dat voorscheiding van de gier noodzakelijk is. Door middel van een decanteercentrifuge worden de grove vaste delen afgescheiden. De dunne fractie gaat naar een bioreactor waarin zuurstof wordt toegevoerd (beluchting) en in een aeroob milieu organische stof microbiologisch wordt afgebroken en stikstof wordt omgezet in nitraat. Vervolgens vindt in een tweede reactor (zonder beluchting) onder anaerobe omstandigheden denitrificatie plaats waarbij nitraat wordt omgezet in stikstofgas. Op deze wijze wordt een groot deel van het organisch materiaal en de stikstof uit de kalvergier verwijderd. Na biologische behandeling wordt de dunne fractie overgepompt naar een bezinktank waar slibafscheiding plaatsvindt. Het effluent wordt op het vuilwaterriool geloosd en afgevoerd naar een RWZI. In deze MVI is dus sprake van voorzuivering. De belangrijkste procesonderdelen van de biologische voorzuiveringsinstallatie zijn schematisch weergegeven in Figuur 2.3.

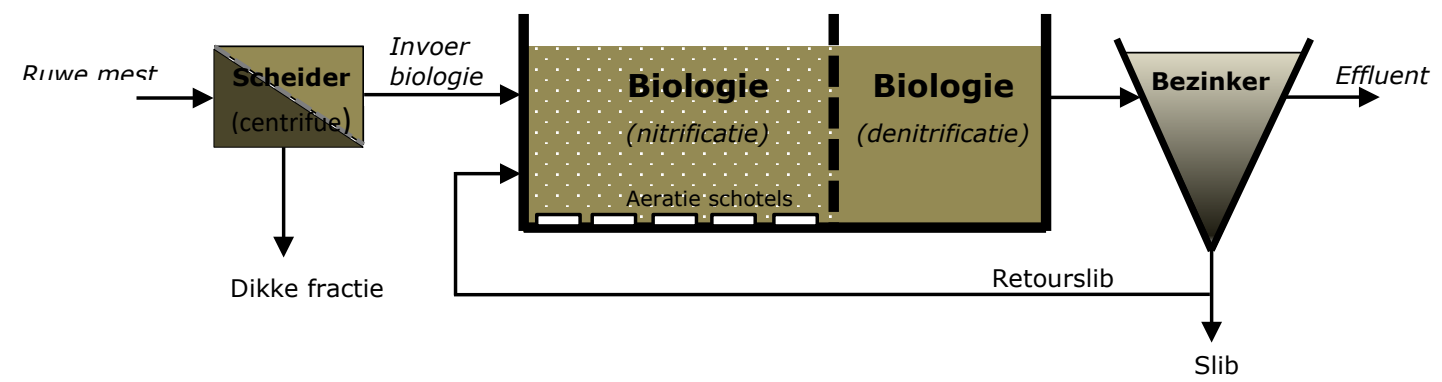

Figuur 2.3 Schematische weergave van het kalvergierverwerkingsproces met biologische voorzuivering.

\subsubsection{Indampen}

In de hier beschouwde mestverwerkingsinstallatie wordt indampen onder verlaagde druk toegepast voor het indikken van de dunne mestfractie. De dunne fractie ontstaat na mechanische scheiding van digestaat (uit co-vergisting van varkensmest en bijproducten) d.m.v. een zeefbandpers gevolgd door flotatie. Bij indampen wordt warmte aan de vloeistof toegevoegd, waardoor water verdampt (door koken) en de dunne mestfractie indikt. Door het verlagen van de druk in de indamper wordt de kooktemperatuur verminderd zodat laagwaardige warmte kan worden gebruikt, in dit geval is de warmte afkomstig van de warmtekrachtkoppeling (WKK) die gevoed wordt door biogas uit de vergister. Er wordt in meerdere trappen gewerkt waarbij de damp van de eerste trap wordt gebruikt als warmtebron voor de tweede trap enzovoort. Door afkoeling van de waterdamp ontstaat een condensaat dat nog vluchtige verbindingen, met name ammoniak, bevat. Ammoniak wordt uit het condensaat gestript in een geïntegreerde stripper onder toevoeging van zwavelzuur met als product ammoniumsulfaat. De ingedampte reststroom, het K-concentraat, bestaat uit een vloeibare stroom met een gehalte aan kalium dat een factor $6-7$ hoger is dan van het oorspronkelijke digestaat. Uit het indampproces ontstaan een $\mathrm{K}$-concentraat, een $\mathrm{N}$-concentraat en spuiwater als eindproducten. Van elke 1000 I digestaat die de MVI ingaat ontstaat grofweg 50 I N-concentraat, 100 I K-concentraat en 600 I spuiwater. De rest is dikke fractie, die van het bedrijf wordt afgevoerd. Het spuiwater wordt in een omgekeerde osmose installatie en een ionenwisselaar gezuiverd alvorens het als effluent wordt geloosd op het oppervlaktewater. De OO en IW zijn in 2020 in gebruik genomen. Er zijn zowel vóór als ná $\mathrm{OO}$ en IW monsters genomen. Het processchema van de MVI met indamping wordt schematisch weergegeven in Figuur 2.4. 


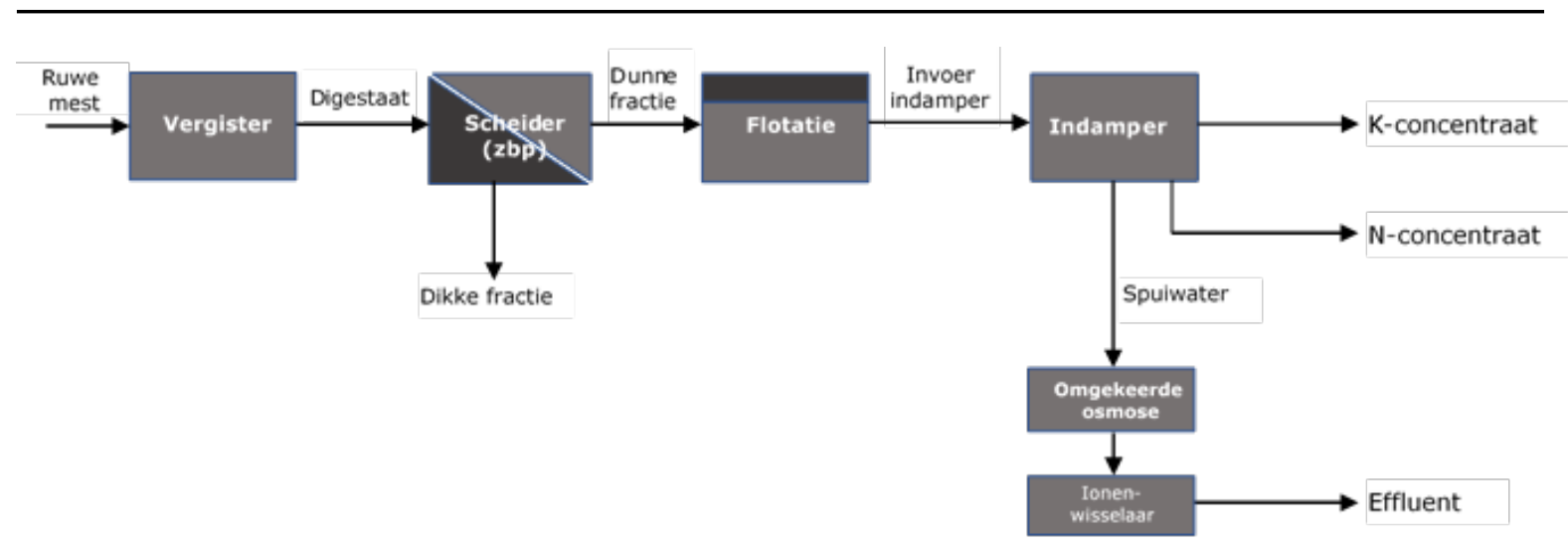

Figuur 2.4 Schematische weergave van het mestverwerkingsproces met indamping.

\subsection{Bemonstering en meting}

Bij elk van de MVI's werden meerdere bemonsteringen uitgevoerd, met een frequentie van eens per 4 tot 8 weken. De tijd tussen de laatste twee bemonsteringen bij de MBR-UF installatie bedroeg één week. De eerste twee bemonsteringen waren beperkt wat betreft het aantal processtromen; ruwe mest werd niet bemonsterd. In het tweede deel van de meetcampagne werden alle genoemde processtromen bemonsterd.

Bij elke bemonstering werd per processtroom een steekmonster van ca. 1 I genomen via een daarvoor bestemde aftapkraan. Uitzondering hierop waren ruwe mest, die werd bemonsterd uit een opslag waaruit de scheider werd gevoed, en de invoer van de UF, die werd bemonsterd uit de denitrificatietank. Voor meting van micro-organismen in de effluenten bedroeg het monstervolume 5 I voor bacteriën en 20 I voor virussen.

Onopgeloste bestanddelen werden uitsluitend gemeten in de effluenten van de MVI's, omdat deze in de andere processtromen niet voldoende nauwkeurig te bepalen zijn. Kobalt en seleen (later aan het meetprogramma toegevoegd) werden uitsluitend gemeten in ruwe mest en in effluenten. In de andere processtromen werden alle parameters gemeten, waarvan hormoonstoffen alleen in de tweede helft van de meetcampagne.

\subsection{Parameters}

De zuiveringsefficiëntie van de 4 typen MVI's werd vastgesteld voor algemene chemische parameters en de voorzorgparameters zware metalen, antibiotica, hormoonstoffen en micro-organismen.

Algemene chemische parameters

De volgende algemene chemische parameters werden gemeten:

- $\quad B Z V, C Z V$

- P-totaal, $\mathrm{P}-\mathrm{PO}_{4}$

- $\quad \mathrm{N}$-totaal, $\mathrm{NH}_{4}-\mathrm{N}, \mathrm{NO}_{3}-\mathrm{N}, \mathrm{NO}_{2}-\mathrm{N}$

- $\quad \mathrm{pH}$, geleidbaarheid (EC)

- $\mathrm{Cl}^{-}, \mathrm{S}, \mathrm{K}$

- Onopgeloste bestanddelen

Analyse van BZV en CZV werd uitgevoerd door Aqualysis in Zwolle evenals onopgeloste bestanddelen. De andere algemene chemische parameters werden gemeten door Centraal Bodemkundig Laboratorium (CBLB) in Wageningen.

Zware metalen

De volgende zware metalen werden gemeten:

- As, Ba, Cd, Co, Cr, Cu, Hg, Ni, Pb, Zn, U en $\mathrm{V}$ en daarnaast Se 
Deze metalen behoren tot de probleemstoffen of prioritaire stoffen waarvoor Europese normen zijn opgesteld voor oppervlaktewater in het kader van de Kaderrichtlijn water (Richtlijn 2000/60/EG ${ }^{1}$ ). De meting van zware metalen werd uitgevoerd door Wageningen Food Safety Research (WFSR).

\section{Antibiotica}

In dit onderzoek werden antibiotica, die (veel) in de varkens- en kalverhouderij worden gebruikt, gemeten volgens een gestandaardiseerd analyseprotocol waarin 55 verschillende stoffen waren opgenomen. De metingen werden uitgevoerd door Wageningen Food Safety Research (WFSR).

\section{Hormoonstoffen}

In de tweede helft van het onderzoek werden in de processtromen eveneens hormoonstoffen (oestrogene activiteit) gemeten. Deze metingen werden uitgevoerd door Bio Detection Systems (BDS) in Amsterdam.

\section{Micro-organismen}

De volgende bacteriën en virussen, die voor kunnen komen in varkensmest en kalvergier, werden gemeten:

- $\quad$ E. coli (indicator voor Gram negatieve bacteriën)

- Enterokokken (indicator voor Gram positieve bacteriën)

- Sporen van sulfiet-reducerende Clostridia (bacteriën die sporen vormen en daardoor vergelijkbaar gedrag vertonen als parasieten/protozoa. Indicator voor sporevormende bacteriën)

- $\quad$ ESBL-of AmpC producerende E. coli (E. coli resistent voor derde generatie cefalosporin antibiotica, onder ander door de productie van het enzym extended-spectrum-beta-lactamase of AmpC cephalosporinase. ESBL worden door de WHO als hoog prioritair gezien.)

- $\quad$ Sporen van Clostridium difficile (pathogeen)

- $\quad$ MRSA (Methicilline resistente Staphylococcus aureus. Antibioticaresistente bacterie die o.a. voorkomt bij varkens en mensen)

- Campylobacter spp. (pathogeen)

- Somatische colifagen (bacterievirus die veel voorkomt in feces en hetzelfde gedrag vertoont als andere virussen. Indicator voor virussen)

- Hepatitis E-virus (darmvirus die vrij algemeen bij varkens en in varkensmest voorkomt en ziekte kan veroorzaken bij de mens. De gebruikte methode geeft alleen info over aanwezigheid; niet over het infectierisico).

De metingen van micro-organismen werden uitgevoerd door RIVM.

\subsection{Analyse methoden}

\subsubsection{Chemische parameters}

De in dit onderzoek toegepaste analysemethoden en daarbij geldende detectielimieten voor gemeten chemische parameters zijn gegeven in Tabel 2.

Tabel 2 Toegepaste analysemethoden en detectielimieten voor chemische parameters.

$\begin{array}{llr}\text { Parameter } & \text { Analyse methode } & \text { Detectie limiet } \\ \text { Algemene parameters } & & 1 \text { mg (bandbreedte 20,4\%) } \\ \text { BZV } & \text { Conform NEN-EN 1899-1 } & 5 \text { mg (bandbreedte 10,1\%) } \\ \text { CZV } & \text { Conform NEN 6633 (2006) } & 5 \text { mg (bandbreedte 8,6\%) } \\ \text { Onopgeloste } & \text { Conform NEN-EN } 872 \text { en NEN 6499 } & \\ \text { :anddelen } & \mathrm{H}_{2} \mathrm{SO}_{4} \text {-Se destructie; gemeten met segmented flow analyser } & \\ \text { N-totaal, P-totaal } & \text { bij } 660 \mathrm{~nm}(\mathrm{~N}) \text { en } 880 \mathrm{~nm}(\mathrm{P}) & \end{array}$

\footnotetext{
${ }^{1}$ RICHTLIJN 2000/60/EG VAN HET EUROPEES PARLEMENT EN DE RAAD van 23 oktober 2000 tot vaststelling van een kader voor communautaire maatregelen betreffende het waterbeleid (PB L 327 van 22.12.2000, blz. 1)
} 
$\mathrm{K}, \mathrm{S}$

$\mathrm{NH}_{4}-\mathrm{N}, \mathrm{NO}_{2}-\mathrm{N}, \mathrm{NO}_{3}-\mathrm{N}$

$\mathrm{Cl}, \mathrm{P}-\mathrm{PO}_{4}$

$\mathrm{EC}, \mathrm{pH}$
Magnetron ontsluiting; gemeten met ICP-OES

$1 \mathrm{M} \mathrm{KCl}$ extractie: $3 \mathrm{~g}$ ruw materiaal met $30 \mathrm{ml} 1 \mathrm{M} \mathrm{KCl} 1 \mathrm{~h}$ geschud, gefilterd over $0,45 \mu$ en $10 x$ verdund met water; gemeten met spectrofotometer

Water extractie: $3 \mathrm{~g}$ ruw materiaal met $30 \mathrm{ml}$ demi water $1 \mathrm{~h}$ geschud, gefilterd over $0,45 \mu$ en $10 x$ verdund met water; gemeten met spectrofotometer

Vloeistoffen direct in monster; vaste fractie na extractie, $5 \mathrm{~g}$ verdund met $25 \mathrm{ml}$ demi water $1 \mathrm{~h}$ geschud

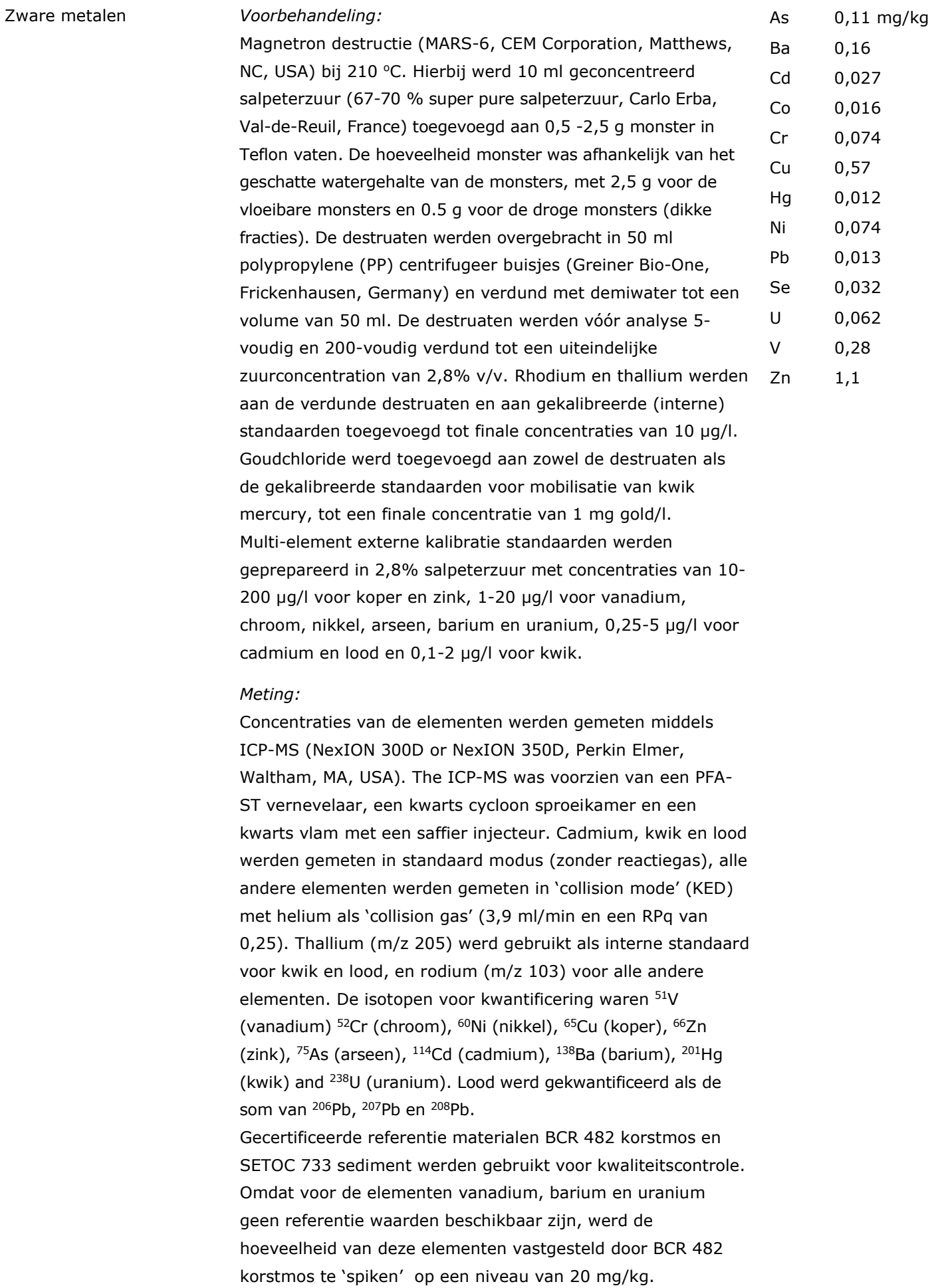

\section{Voorbehandeling:}

Magnetron destructie (MARS-6, CEM Corporation, Matthews, $\mathrm{NC}$, USA) bij $210^{\circ} \mathrm{C}$. Hierbij werd $10 \mathrm{ml}$ geconcentreerd salpeterzuur (67-70 \% super pure salpeterzuur, Carlo Erba, Val-de-Reuil, France) toegevoegd aan 0,5 -2,5 g monster in Teflon vaten. De hoeveelheid monster was afhankelijk van het geschatte watergehalte van de monsters, met $2,5 \mathrm{~g}$ voor de vloeibare monsters en $0.5 \mathrm{~g}$ voor de droge monsters (dikke fracties). De destruaten werden overgebracht in $50 \mathrm{ml}$ polypropylene (PP) centrifugeer buisjes (Greiner Bio-One, Frickenhausen, Germany) en verdund met demiwater tot een volume van $50 \mathrm{ml}$. De destruaten werden vóór analyse 5voudig en 200 -voudig verdund tot een uiteindelijke zuurconcentration van $2,8 \% \mathrm{v} / \mathrm{v}$. Rhodium en thallium werden aan de verdunde destruaten en aan gekalibreerde (interne) standaarden toegevoegd tot finale concentraties van $10 \mu \mathrm{g} / \mathrm{l}$. Goudchloride werd toegevoegd aan zowel de destruaten als de gekalibreerde standaarden voor mobilisatie van kwik mercury, tot een finale concentratie van $1 \mathrm{mg}$ gold/l. Multi-element externe kalibratie standaarden werden geprepareerd in $2,8 \%$ salpeterzuur met concentraties van 10 $200 \mu \mathrm{g} / \mathrm{l}$ voor koper en zink, 1-20 $\mu \mathrm{g} / \mathrm{l}$ voor vanadium, chroom, nikkel, arseen, barium en uranium, 0,25-5 $\mu \mathrm{g} / \mathrm{l}$ voor cadmium en lood en 0,1-2 $\mu \mathrm{g} / \mathrm{l}$ voor kwik.

Meting:

Concentraties van de elementen werden gemeten middels ICP-MS (NexION 300D or NexION 350D, Perkin Elmer, Waltham, MA, USA). The ICP-MS was voorzien van een PFAST vernevelaar, een kwarts cycloon sproeikamer en een kwarts vlam met een saffier injecteur. Cadmium, kwik en lood werden gemeten in standaard modus (zonder reactiegas), alle andere elementen werden gemeten in 'collision mode' (KED) met helium als 'collision gas' (3,9 ml/min en een RPq van $0,25)$. Thallium ( $\mathrm{m} / \mathrm{z} 205)$ werd gebruikt als interne standaard voor kwik en lood, en rodium ( $\mathrm{m} / \mathrm{z} 103$ ) voor alle andere elementen. De isotopen voor kwantificering waren ${ }^{51} \mathrm{~V}$ (vanadium) ${ }^{52} \mathrm{Cr}$ (chroom), ${ }^{60} \mathrm{Ni}$ (nikkel), ${ }^{65} \mathrm{Cu}$ (koper), ${ }^{66} \mathrm{Zn}$ (zink), ${ }^{75} \mathrm{As}$ (arseen), ${ }^{114} \mathrm{Cd}$ (cadmium), ${ }^{138} \mathrm{Ba}$ (barium), ${ }^{201} \mathrm{Hg}$ (kwik) and ${ }^{238} \mathrm{U}$ (uranium). Lood werd gekwantificeerd als de som van ${ }^{206} \mathrm{~Pb}$, ${ }^{207} \mathrm{~Pb}$ en ${ }^{208} \mathrm{~Pb}$.

Gecertificeerde referentie materialen BCR 482 korstmos en SETOC 733 sediment werden gebruikt voor kwaliteitscontrole. Omdat voor de elementen vanadium, barium en uranium geen referentie waarden beschikbaar zijn, werd de hoeveelheid van deze elementen vastgesteld door BCR 482 korstmos te 'spiken' op een niveau van $20 \mathrm{mg} / \mathrm{kg}$.

$\begin{array}{ll}\mathrm{As} & 0,11 \mathrm{mg} / \mathrm{kg} \\ \mathrm{Ba} & 0,16 \\ \mathrm{Cd} & 0,027 \\ \mathrm{Co} & 0,016 \\ \mathrm{Cr} & 0,074 \\ \mathrm{Cu} & 0,57 \\ \mathrm{Hg} & 0,012 \\ \mathrm{Ni} & 0,074 \\ \mathrm{~Pb} & 0,013 \\ \mathrm{Se} & 0,032 \\ \mathrm{U} & 0,062 \\ \mathrm{~V} & 0,28 \\ \mathrm{Zn} & 1,1\end{array}$




\begin{tabular}{|c|c|c|}
\hline Parameter & Analyse methode & Detectie limiet \\
\hline Antibiotica & 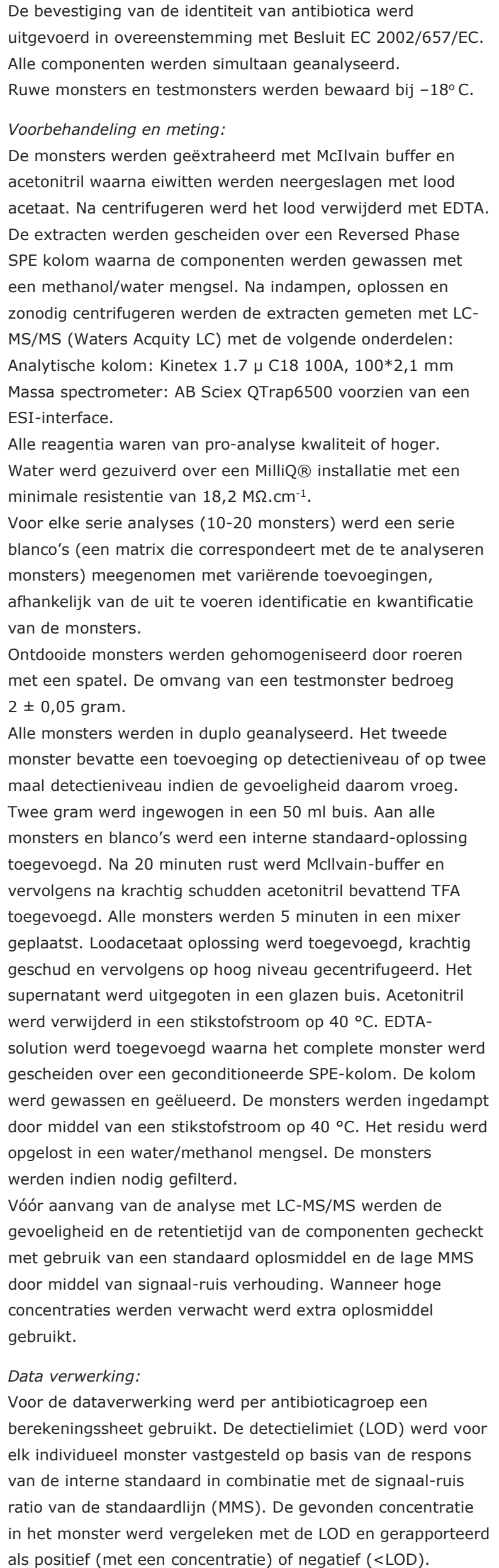 & $\begin{array}{l}\text { De detectielimieten voor } \\
\text { sulfadimidine, sulfadiazine } \\
\text { en trimethoprim werden } \\
\text { ingesteld op } 5 \mu \mathrm{g} / \mathrm{kg} \text { en voor } \\
\text { de andere componenten op } \\
20 \mu \mathrm{g} / \mathrm{kg} \text {. }\end{array}$ \\
\hline
\end{tabular}




\section{Voorbehandeling:}

Ruwe monsters zijn geëxtraheerd ( $3 x$ ) met ethylacetaat. Het extract is opgelost in dimethylsulfoxide (DMSO).

Hoeveelheid gebruikt materiaal was afhankelijk van de concentratie van het monster en varieerde van $10,2 \mathrm{~g}$ (digestaat) tot $254 \mathrm{~g}$ (OO effluent).

Bepaling hormonale activiteit:

De hormonale activiteit is bepaald met een CALUX (Chemical Activated Luciferase gene eXpression) assay. CALUX assays stellen de hormonale activiteit vast van de stoffen in het aangeleverde monster en maken gebruik van een aangepaste cellijn, in dit geval een humane borstkankercellijn, waar een receptor is ingebouwd die gevoelig is voor een bepaalde groep van hormonen of stoffen met een hormonale werking. Als stoffen binden aan deze receptor vindt een serie reacties plaats, met als uiteindelijk effect het uitzenden van licht. Hoe meer licht wordt uitgezonden hoe meer hormonale activiteit het monster bevat. De geselecteerde receptor voor dit onderzoek is de oestrogene receptor (ERalpha-CALUX). Als substraat werd gebruik gemaakt van BDS illuminate mix die luciferine bevat. De luminescentie werd gemeten met een Mithras LB 940 (Berthold Technologies).

Het effect wordt uitgedrukt in equivalenten van een referentie-stof, in dit onderzoek in equivalenten van het vrouwelijke hormoon $17 \beta$-oestradiol (ng 17ß EEQ/g).
De detectielimiet (LOQ) verschilde per monster en was afhankelijk van de hoeveelheid ingewogen materiaal; hoe kleiner de ingewogen hoeveelheid, hoe hoger de detectielimiet. 


\subsubsection{Micro-organismen}

\section{Monstervoorbehandeling}

Alle monsters werden ingezet binnen 24 uur na ontvangst, dit was over het algemeen binnen 24 uur na bemonstering en maximaal binnen 29 uur na bemonstering.

\section{Bacteriën}

Voor de bepaling van E. coli, Enterokokken en sulfietreducerende Clostridia werden vloeibare fracties, dikke fracties en effluent $O O$ voorbehandeld.

Van de vloeibare fracties (= ruwe mest, invoer 00 , concentraat 00 ) werd 50 gram 1:1 verdund in peptone-fysiologisch zout (PFZ) en dit werd gehomogeniseerd met behulp van een pulsifier (Microgen Bioproducts Ltd). Van de gehomogeniseerde suspensies werd een verdunningsreeks gemaakt in PFZ $\left(10^{-1} \mathrm{t} / \mathrm{m}^{10^{-4}}\right)$.

Van de droge fracties werd 15 gram 1:1 verdund in PFZ. $20 \mathrm{ml}$ uit de 1:1 verdunning werd 1:5 verdund in PFZ en dit werd gehomogeniseerd met behulp van een pulsifier (Microgen Bioproducts Ltd). Van de gehomogeniseerde suspensies werd een verdere verdunningsreeks gemaakt in PFZ $\left(10^{-2} \mathrm{t} / \mathrm{m} \mathrm{10}^{-4}\right)$.Van het effluent 00 werd twee keer $500 \mathrm{ml}$ gefiltreerd door een 0,45 $\mu \mathrm{m}$ membraanfilter (47 $\mathrm{mm}$ mixed cellulose ester, Merck millipore). De filters werden vervolgens geplaatst op vaste voedingsbodems.

\section{Virussen}

Voor de bepaling van somatische colifagen en hepatitis $\mathrm{E}$ virus werd het effluent $\mathrm{OO}$ eerst geconcentreerd. . Hiervoor werd aan circa 20 liter effluent $\mathrm{OO} \mathrm{MgCl} 2$ (4,17 mol/L, Sartorius) toegevoegd tot een concentratie van $0,05 \mathrm{M}$, en de $\mathrm{pH}$ werd verlaagd tot 3,8 met $1 \mathrm{M} \mathrm{HCl}$. $\mathrm{Na}$ filtratie van dit concentraat over een negatief geladen kaarsfilter $(1,2 \mu \mathrm{m}, 4$ inch cellulose acetaat, Milligard cartridge filter, Millipore) zijn virussen en bacteriofagen van het filter geëlueerd met circa $600 \mathrm{ml} 3 \%$ beefextractoplossing $(\mathrm{pH}>9,0)$ (Gibco). Het eluaat werd geneutraliseerd door toevoeging van $55 \mathrm{ml}$ azijnzuuracetaatbuffer $(\mathrm{pH} 5,0)$ en verder geconcentreerd door middel van ultrafiltratie (Cellulose triacetaat, MWCO 10 kD, ø100 mm, Sartorius) onder hoge druk (3 bar). Het geconcentreerde monster werd van het filter afgespoeld met 3\%-beefextractoplossing $(\mathrm{pH}>9,0)$ tot een hoeveelheid variërend van 10 tot $30 \mathrm{gram}$. Het resterende concentraat is geanalyseerd op aantallen somatische colifagen en hepatitis $\mathrm{E}$ virussen.

\section{Bacterie- en virusbepalingen}

E. coli

De bepaling van $E$. coli is gebaseerd op de voorschriften beschreven in ISO 9308-1 (voor wat betreft membraanfiltratie, geldt alleen voor effluenten) en ISO 16649-2 (voor wat betreft de media en incubatiecondities). Voor de bepalingen in mestfracties werd $100 \mu \mathrm{l}$ van de $1: 1 \mathrm{t} / \mathrm{m} 10^{-4}$ verdunningen

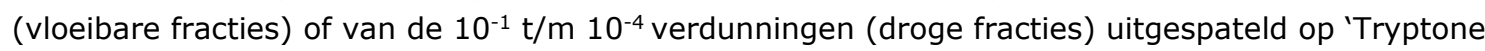
bile X-glucuronide agar' (TBX) (in totaal respectievelijk 0,06111 en 0,01111 gram mest). De filters met gefiltreerd effluent (maximaal $2 \times 1000 \mathrm{ml}$ ) werden ook op TBX agar geplaatst. Alle kweken werden 4-5 uur bij $37^{\circ} \mathrm{C}$ geïncubeerd, gevolgd door $18-22$ uur bij $44^{\circ} \mathrm{C}$. De kolonies met een groenblauwe kleur werden geteld.

\section{Intestinale enterokokken}

De bepaling van intestinale enterokokken is gebaseerd op de methode voorgeschreven in ISO 7899-2. De in deze norm beschreven methode voor membraanfiltratie werd alleen voor de effluenten uitgevoerd; de media werden voor alle fracties toegepast. Voor de bepalingen in mestfracties werd

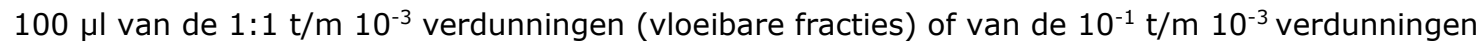
(droge fracties) uitgespateld op 'Slanetz en Bartley agar' (S\&B) (in totaal respectievelijk 0,0611 en 0,0111 gram mest). De filters met gefiltreerd effluent (maximaal 2x1000 ml) werden ook op S\&B agar geplaatst. Alle kweken werden 4-5 uur bij $37^{\circ} \mathrm{C}$ geïncubeerd, gevolgd door $40-44$ uur bij $44^{\circ} \mathrm{C}$, zoals voorgeschreven door de fabrikant (Oxoid). Na incubatie werden de (donker)rode kolonies geteld en 10 verdachte kolonies per monster ter bevestiging afgeënt op 'Bile Aesculin agar' (BAA) gevolgd door 1824 uur incubatie bij $44^{\circ} \mathrm{C}$. Voor de telling werd het percentage kolonies dat bevestigd werd als intestinale enterokokken (zwarte kolonies met zwarte hof) vermenigvuldigd met het aantal kolonies dat was geteld op S\&B. 


\section{Sporen van sulfiet reducerende Clostridia}

De bepaling van sporen van sulfiet reducerende Clostridia is gebaseerd op de methode voorgeschreven in ISO 6461-2. De in deze norm beschreven methode voor membraanfiltratie werd alleen voor de effluenten uitgevoerd; de media werden voor alle fracties toegepast. Voor de bepalingen werden alle samples 15 minuten verhit bij $75 \pm 5^{\circ} \mathrm{C}$. Van de mestfracties werd $100 \mu \mathrm{l}$ van

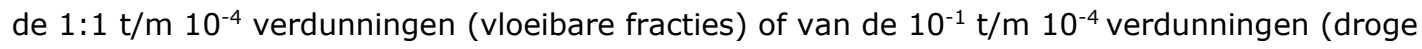
fracties) uitgespateld op 'Iron Sulfite agar' (ISA, Condalab) (in totaal respectievelijk 0,06111 en 0,01111 gram mest). De filters met gefiltreerd effluent (maximaal $2 \times 1000 \mathrm{ml}$ ) werden ook op ISA agar geplaatst. Alle kweken werden onder anaerobe omstandigheden geïncubeerd bij $37^{\circ} \mathrm{C}$ voor 18 24 uur en 40-48 uur, en de zwarte kolonies werden geteld.

\section{Clostridium difficile}

Voor de bepaling van $C$. difficile werden alle samples 15 minuten verhit bij $75 \pm 5{ }^{\circ} \mathrm{C}$. Van de mestfracties werd $100 \mu \mathrm{l}$ of $1 \mathrm{ml}$ (in drie porties van $333 \mu \mathrm{l}$ ) van verschillende verdunningen uitgespateld op CHROMID C. difficile (Biomerieux). De filters met gefiltreerd OO effluent (2×1000 ml) werden ook op CHROMID C. difficile geplaatst. Alle kweken werden $18-24$ uur bij $37^{\circ} \mathrm{C}$ geïncubeerd onder anaerobe omstandigheden. Indien nodig werden de platen nogmaals $18-24$ uur bij $37^{\circ} \mathrm{C}$ geïncubeerd onder anaerobe omstandigheden. De zwarte, onregelmatige kolonies werden geteld.

\section{Campylobacter}

Voor de bepalingen in mestfracties werd 10 gram opgehoopt in $90 \mathrm{ml}$ Preston medium. De filters met gefiltreerd effluent (maximaal $2 \times 1000 \mathrm{ml}$ ) werden ook in $90 \mathrm{ml}$ Preston medium opgehoopt. Alle ophopingen werden $40-48$ uur bij $37^{\circ} \mathrm{C}$ geïncubeerd onder microaerofiele omstandigheden. Van elke ophoping werd $10 \mu \mathrm{l}$ afgeënt op een modified CCDA plaat (mCCDA, Oxoid). Alle platen werden 40-48 uur bij $42,5^{\circ} \mathrm{C}$ geïncubeerd onder microaerofiele omstandigheden. De kolonies met een glanzend oppervlak werden microscopisch bevestigd.

ESBL-producerende E. coli (3e-generatie cephalosporine resistente E. coli) Voor de bepalingen in mestfracties werd $100 \mu \mathrm{l}$ of $1 \mathrm{ml}$ (in drie porties van $333 \mu \mathrm{l}$ ) van verschillende verdunningen uitgespateld op 'Tryptone bile X-glucuronide agar' (TBX) aangevuld met $1 \mu \mathrm{g} / \mathrm{ml}$ CTX. De filters met gefiltreerd effluentt (maximaal $2 \times 1000 \mathrm{ml}$ ) werden ook op TBX agar + CTX geplaatst. Alle kweken werden 4-5 uur bij $37^{\circ} \mathrm{C}$ geïncubeerd, gevolgd door $18-22$ uur bij $44^{\circ} \mathrm{C}$. De kolonies met een groenblauwe kleur werden geteld. De resulterende kolonies zijn resistent voor derde generatie cefalosporin antibiotica. Dit kan zowel door productie van extended-spectrum beta-lactamase enzymen (ESBLs) alsook van AmpC cephalosporinasen veroorzaakt kunnen zijn.

\section{MRSA (Methicilline-resistente Staphylococcus aureus)}

Voor de bepalingen in mestfracties werd 0,1, 10 en 100 gram opgehoopt in 0,9, 9 en 90 ml Mueller Hinton broth (Carl Roth). Alle ophopingen werden 18-24 uur bij $37^{\circ} \mathrm{C}$ schuddend geïncubeerd. Van elke ophoping werd $1 \mathrm{ml}$ toegevoegd aan $9 \mathrm{ml}$ CASO broth (Carl Roth) $+3,5 \mathrm{mg} / \mathrm{L}$ Cefoxitin (Merck) + $50 \mathrm{mg} / \mathrm{L}$ Aztreonam (MP Biomedicals). De nieuwe ophopingen werden 18-24 uur bij $37^{\circ} \mathrm{C}$ schuddend geïncubeerd. Van elke ophoping in CASO werd $10 \mu \mathrm{l}$ afgeënt op CHROMagar MRSA (Biotrading). Alle platen werden $18-24$ uur bij $37^{\circ} \mathrm{C}$ geïncubeerd. De roze kolonies werden geteld.

Voor de bepaling in effluent werd $2 \times 1000 \mathrm{ml}$ gefiltreerd. De filters werden op CHROMagar MRSA (Biotrading) geplaatst en $18-24$ uur bij $37^{\circ} \mathrm{C}$ geïncubeerd. De roze kolonies werden geteld.

\section{Somatische colifagen}

De bepaling van het aantal somatische colifagen werd uitgevoerd zoals voorgeschreven in ISO 10705-

2. Van de mest fracties (alle fracties behalve de effluenten) werd als voorbewerking 10 gram 1:10 verdund in PFZ en gehomogeniseerd. Van de gehomogeniseerde suspensies werd een verdunningsreeks gemaakt in PFZ $\left(10^{-2} \mathrm{t} / \mathrm{m} 10^{-5}\right)$. Voor de enumeratie van somatische colifagen is een mengsel van $1 \mathrm{ml}$ van de nalidixinezuur resistente mutant Escherichia coli CN (WG5), $1 \mathrm{ml}$ monster of van de tienvoudige verdunningen van het monster en $2,5 \mathrm{ml}$ gesmolten voedingsbodem (Scholtens' agar, Oxoid) over een vaste voedingsbodem (Scholtens' agar, Oxoid) in een petrischaal gegoten. Alle platen werden $16-20$ uur bij $37^{\circ} \mathrm{C}$ geïncubeerd, waarna de plaques geteld werden.

\section{Hepatitis $E$ virus}

Van de monsters werd een $10 \%$ suspensie gemaakt door $900 \mu \mathrm{l} \mathrm{Hanks'} \mathrm{Balanced} \mathrm{Salt} \mathrm{Solution}$ (HBSS, calcium, magnesium (Gibco, ThermoFischer scientific) met $0,05 \mathrm{mg} / \mathrm{ml}$ gentamycine toe te 
voegen aan $100 \mathrm{mg}$ van de mest fractie en 30 seconden te vortexen. Na 15 minuten te centrifugeren bij 3000xg werd het supernatant gebruikt voor analyse.

Voor de RNA isolatie uit de mestsuspensies en effluent concentraten (verkregen door middel van voorbehandeling van effluent) werd gebruikt gemaakt van een fast spin-column kit met silica membraan (QIAmp Viral RNA Mini Kit, Qiagen).

De aanwezigheid van Hepatitis $E$ virus werd onderzocht in onverdunde en 10x verdunde RNA extracten m.b.v real-time RT-PCR. Er werd gebruik gemaakt van primers en probe beschreven door Bouwknegt et al (2009). In plaats van de hierin beschreven QueantiTect probe RT-PCR Master kit (Qiagen) werd gebruikt gemaakt van de TaqMan Fast Virus 1-step kit (Invitrogen).

\section{$2.5 \quad$ Dataverwerking}

De samenstelling van de processtromen (ingangsmateriaal, tussenproducten en eindproducten) zijn per type mestverwerkingsinstallatie beschreven door presentatie van gemiddelden en standaarddeviaties van alle gemeten parameters. Verschil in samenstelling tussen de processtromen per bedrijf en tussen de effluenten van de MVI's werden vastgesteld. Per parameter werd vastgesteld of de verschillen tussen de processtromen/effluenten wel of niet significant waren, met een betrouwbaarheid van 95\% (P 0,05). Regressie- en variantieanalyses werden uitgevoerd met de laatste editie van Genstat, of, voor micro-organismen, met R.

De gerapporteerde gemiddelde concentraties zware metalen en antibiotica werden berekend als som van de gemeten reële waarden gedeeld door het aantal reële waarden. De gerapporteerde waarden < detectiegrens geven de gemiddelde detectiegrens weer. 


\section{Resultaten}

De resultaten worden gepresenteerd in tabellen en figuren.

De tabellen geven per type MVI de gemiddelde waarden van de gemeten parameters in de verschillende processtromen. Tussen haakjes staat achtereenvolgens het aantal monsters met meetwaarden boven de detectiegrens en het aantal geanalyseerde monsters (waarnemingen) waaruit het gemiddelde is berekend. Bij elke waarde in de tabellen wordt een letter in superschrift gegeven waaraan de volgende betekenis wordt toegekend: als in een regel overeenkomende letters staan dan is het verschil in waarde van de betreffende parameter tussen de processtromen van een type MVI of tussen de vier typen MVI's niet significant, als de letters niet overeenkomen dan is er een significant verschil $(P<0,05)$ in waarde tussen de betreffende processtromen. Zo worden in Tabel 3 bij de BZV, $\mathrm{CZV}$ en $\mathrm{Cl}^{-}$gehalten van de ingangsmaterialen van de vier typen MVI's overeenkomstige letters ( ${ }^{\mathrm{a}}$ ) gegeven. Dit betekent dat de vier ingangsmaterialen wat deze parameters betreft niet significant van elkaar verschillen.

Bij de P-totaal gehalten van de ingangsmaterialen worden voor OO, MBR-UF en biologische voorzuivering verschillende letters $\left({ }^{a}\right),\left({ }^{b}\right)$ en $\left({ }^{c}\right)$ gegeven. Dit betekent dat de P-totaal gehalten van deze drie ingangsmaterialen significant van elkaar verschillen. Bij de gehalten van $\mathrm{N}$-totaal van de ingangsmaterialen voor $\mathrm{OO}$ en MBR-UF worden overeenkomstige letters $\left({ }^{\mathrm{a}}\right)$ gegeven en van biologische voorzuivering een andere letter $\left(^{(}\right)$. Dit betekent dat het $\mathrm{N}$-totaal gehalte van het ingangsmateriaal van biologische voorzuivering significant verschilt van die van $O O$ en MBR-UF en de $\mathrm{N}$-totaal gehalten van de ingangsmaterialen van $\mathrm{OO}$ en MBR-UF onderling niet significant verschillen. Tabel 3 laat nog een variant zien, $\mathrm{nl}$. bij de parameters $\mathrm{NO}_{2}-\mathrm{N}+\mathrm{NO}_{3}-\mathrm{N}$ en $\mathrm{K}$ waar bij MBR-UF twee letters $\left({ }^{a b}\right)$ worden gegeven en bij $\mathrm{OO}$ en biologische voorzuivering één letter $\left(^{\mathrm{a}}\right)$ resp. $\left.{ }^{\mathrm{b}}\right)$. De verschillen in de gehalten van $\mathrm{NO}_{2}-\mathrm{N}+\mathrm{NO}_{3}-\mathrm{N}$ en $\mathrm{K}$ moeten als volgt geïnterpreteerd worden: De gehalten van $\mathrm{OO}$ en MBR-UF verschillen niet significant van elkaar. Ook van biologische voorzuivering en MBR-UF verschillen de gehalten niet significant van elkaar. De gehalten van $\mathrm{NO}_{2}-\mathrm{N}+\mathrm{NO}_{3}-\mathrm{N}$ en $\mathrm{K}$ van $\mathrm{OO}$ en biologische voorzuivering zijn onderling wel significant verschillend.

De figuren tonen eveneens per type MVI de gemiddelde waarden van de gemeten parameters in de verschillende processtromen. In de figuren wordt bovendien de variatie in de waarden (plus en min 1 $x$ de standaarddeviatie) aangegeven. 


\subsection{Samenstelling van de ingangsmaterialen van MVI's}

Tabel 3 Gemiddelde gehalten van algemene chemische parameters in het ingangsmateriaal van de 4 typen MVI's. Betekenis van de letters in superscript: verschillende letters per regel betekent dat voor de betreffende parameter het verschil in gehalte in vergelijking met het ingangsmateriaal van 00 significant is $(P<0,05)$. Tussen haakjes staat het aantal warnemingen boven de detectiegrens gevolgd door het totale aantal waarnemingen.

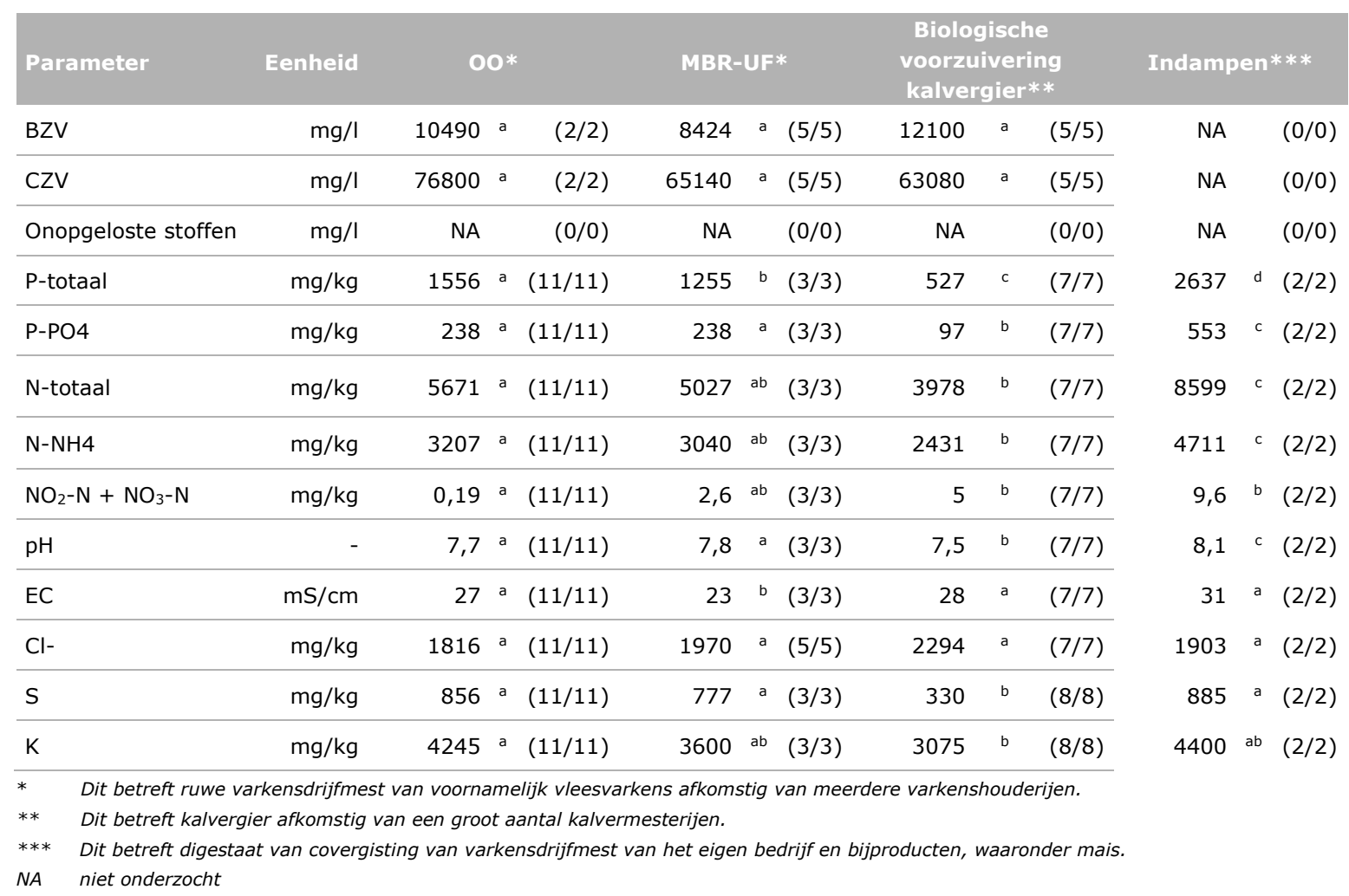



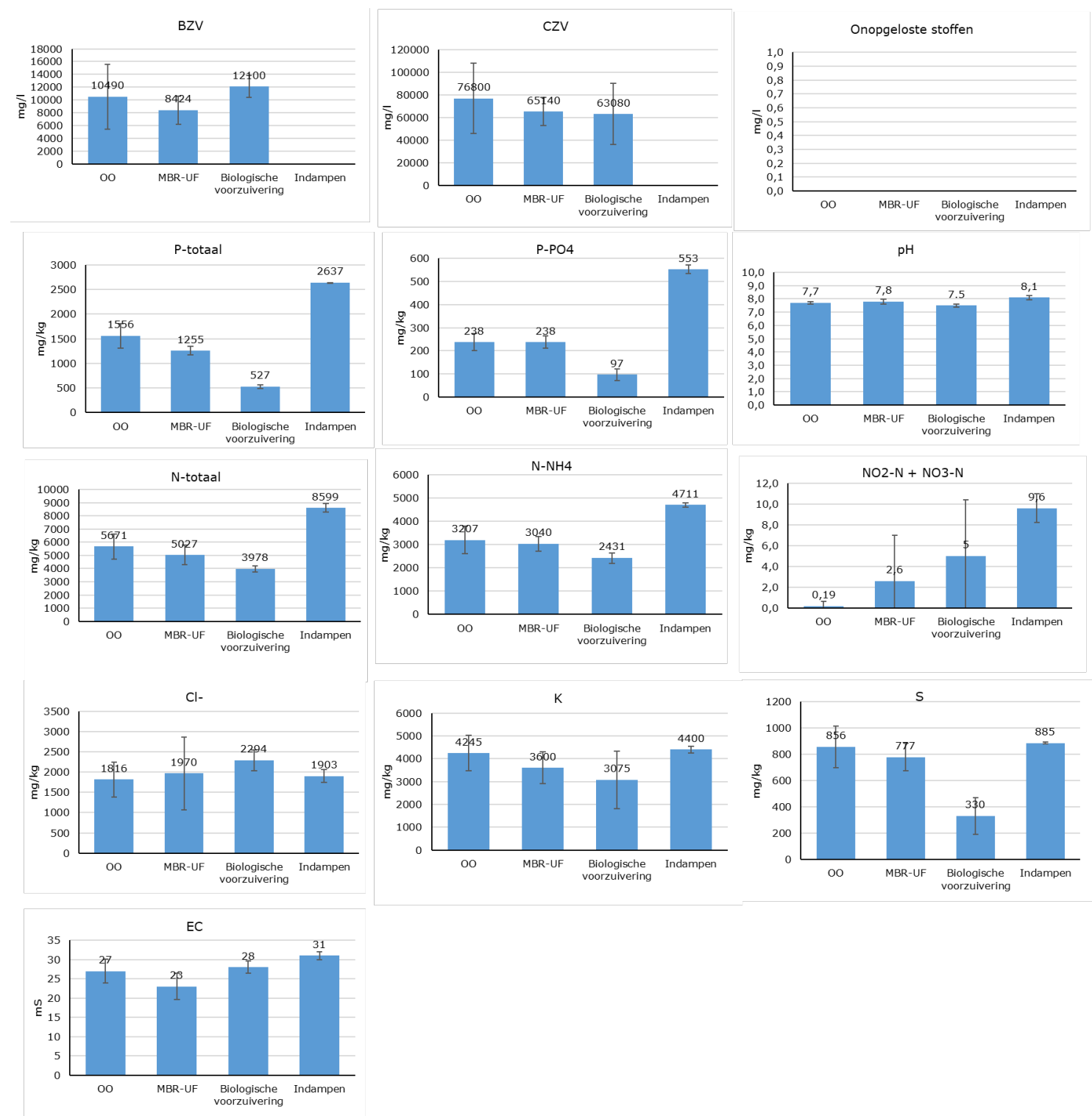

Figur 3.1 Gemiddelde gehalten en variaties (plus en min 1 x standaarddeviatie) van algemene chemische parameters in het ingangsmateriaal van vier verschillende mvi's.

De ingaande ruwe varkensdrijfmest van de OO- en MBR-UF installaties is wat betreft de algemene chemische parameters gelijkwaardig; de gevonden gehalten komen goed overeen met de gehalten die in eerdere onderzoeken zijn gemeten (Hoeksma et al, 2011; Hoeksma \& de Buisonjé, 2015). De ingaande mest van $\mathrm{OO}$ en MBR-UF verschilt van het ingangsmateriaal van de kalvergiervoorzuiveringsinstallatie; kalvergier toont met name lagere gehalten aan P-totaal, N-totaal, $\mathrm{N}-\mathrm{NH}_{4}$ en $\mathrm{S}$. De gemiddelde P-totaal en $\mathrm{N}$-totaal gehalten van de kalvergier zijn vergelijkbaar met de forfaitaire waarden die in het kader van de mestwetgeving worden gehanteerd voor mestcode 18/19 (RVO.nl, 2019). Voor BZV en CZV gehalten in varkensdrijfmest en kalvergier zijn geen referentiewaarden gevonden.

Het ingangsmateriaal (digestaat na co-vergisting van varkensmest) van indampen bevat hogere gehalten van de meeste algemene chemische parameters dan de ingangsmaterialen van OO, MBR-UF en biologische voorzuivering. Met name de gehalten aan fosfor- en stikstofcomponenten zijn substantieel hoger. Dit is mede toe te schrijven aan het gebruik van bijproducten, zoals mais, naast varkensmest als voeding van de vergistingsinstallatie. 
Tabel 4 Gemiddelde concentraties van zware metalen in het ingangsmateriaal van de 4 typen MVI's. Betekenis van de letters in superscript: verschillende letters per regel betekent dat voor de betreffende parameter het verschil in concentratie in vergelijking met het ingangsmateriaal van 00 significant is $(P<0,05)$. Tussen haakjes staat het aantal waarnemingen boven de detectiegrens gevolgd door het totale aantal waarnemingen.

\begin{tabular}{|c|c|c|c|c|c|c|c|c|c|c|c|c|c|}
\hline \multirow{2}{*}{$\begin{array}{l}\text { Parameter } \\
\mathrm{Cd}\end{array}$} & \multirow{2}{*}{$\begin{array}{l}\text { Eenheid } \\
\text { mg/kg }\end{array}$} & \multicolumn{3}{|c|}{$00 *$} & \multicolumn{3}{|c|}{ MBR-UF* } & \multicolumn{3}{|c|}{$\begin{array}{c}\text { Biologische } \\
\text { voorzuivering } \\
\text { kalvergier** }\end{array}$} & \multicolumn{3}{|c|}{ Indampen $* * *$} \\
\hline & & 0,05 & a & $(11 / 11)$ & 0,03 & a & $(3 / 3)$ & $<0,027$ & $\mathrm{~b}$ & $(0 / 4)$ & 0,03 & a & $(1 / 1)$ \\
\hline $\mathrm{Hg}$ & $\mathrm{mg} / \mathrm{kg}$ & $<0,01$ & a & $(0 / 11)$ & $<0,012$ & a & $(0 / 3)$ & $<0,012$ & a & $(0 / 4)$ & $<0,012$ & a & $(0 / 1)$ \\
\hline $\mathrm{Pb}$ & $\mathrm{mg} / \mathrm{kg}$ & 0,19 & $\mathrm{a}$ & $(11 / 11)$ & 0,08 & $\mathrm{a}$ & $(3 / 3)$ & 0,02 & a & $(3 / 4)$ & 0,18 & $\mathrm{a}$ & $(1 / 1)$ \\
\hline As & $\mathrm{mg} / \mathrm{kg}$ & $<0,13$ & a & $(0 / 11)$ & $<0,11$ & a & $(0 / 3)$ & $<0,11$ & a & $(0 / 4)$ & $<0,11$ & a & $(0 / 1)$ \\
\hline $\mathrm{Cr}$ & $\mathrm{mg} / \mathrm{kg}$ & 0,93 & a & $(11 / 11)$ & 0,58 & $\mathrm{ab}$ & $(3 / 3)$ & 0,05 & $\mathrm{~b}$ & $(2 / 4)$ & 0,68 & $\mathrm{ab}$ & $(1 / 1)$ \\
\hline $\mathrm{Ni}$ & $\mathrm{mg} / \mathrm{kg}$ & 1 & a & $(11 / 11)$ & 0,64 & a & $(3 / 3)$ & 0,11 & a & $(3 / 4)$ & 0,79 & a & $(1 / 1)$ \\
\hline $\mathrm{Cu}$ & $\mathrm{mg} / \mathrm{kg}$ & 26 & $a$ & $(11 / 11)$ & 12 & $\mathrm{ab}$ & $(3 / 3)$ & 2,2 & $\mathrm{~b}$ & $(3 / 4)$ & 9 & $\mathrm{ab}$ & $(1 / 1)$ \\
\hline $\mathrm{Zn}$ & $\mathrm{mg} / \mathrm{kg}$ & 95 & a & $(11 / 11)$ & 46 & $\mathrm{a}$ & $(3 / 3)$ & 24 & a & $(4 / 4)$ & 37 & a & $(1 / 1)$ \\
\hline $\mathrm{Ba}$ & $\mathrm{mg} / \mathrm{kg}$ & 5 & a & $(11 / 11)$ & 2,4 & $a$ & $(3 / 3)$ & 0,47 & a & $(3 / 4)$ & 2,8 & a & $(1 / 1)$ \\
\hline V & $\mathrm{mg} / \mathrm{kg}$ & 0,35 & $\mathrm{a}$ & $(5 / 9)$ & 0,32 & $\mathrm{a}$ & $(1 / 1)$ & $<0,28$ & a & $(0 / 4)$ & $<0,28$ & $\mathrm{a}$ & $(0 / 1)$ \\
\hline$U$ & $\mathrm{mg} / \mathrm{kg}$ & 0,04 & $a$ & $(3 / 9)$ & $<0,062$ & a & $(0 / 1)$ & $<0,062$ & a & $(0 / 4)$ & $<0,062$ & a & $(0 / 1)$ \\
\hline Co & $\mathrm{mg} / \mathrm{kg}$ & 0,12 & $\mathrm{a}$ & $(8 / 8)$ & 0,15 & $\mathrm{~b}$ & $(3 / 3)$ & NA & & $(0 / 0)$ & NA & & $(0 / 0)$ \\
\hline $\mathrm{Se}$ & $\mathrm{mg} / \mathrm{kg}$ & 0,26 & a & $(8 / 8)$ & 0,3 & $\mathrm{a}$ & $(3 / 3)$ & NA & & $(0 / 0)$ & NA & & $(0 / 0)$ \\
\hline $\begin{array}{ll}* & D \\
* * & D \\
* * * & D \\
N A & n\end{array}$ & $\begin{array}{l}\text { Dit betreft varke } \\
\text { Dit betreft kalve } \\
\text { Dit betreft diges } \\
\text { niet onderzocht }\end{array}$ & $\begin{array}{l}\text { jifmest va } \\
\text { afkomstic } \\
\text { van cover }\end{array}$ & 9 & $\begin{array}{l}\text { ornamelijk } \\
\text { meerdere } \\
\text { ig van vark }\end{array}$ & $\begin{array}{l}\text { svarkens } \\
\text { mest en bi }\end{array}$ & fkon & nstig var & erdere $b$ & & & & & \\
\hline
\end{tabular}



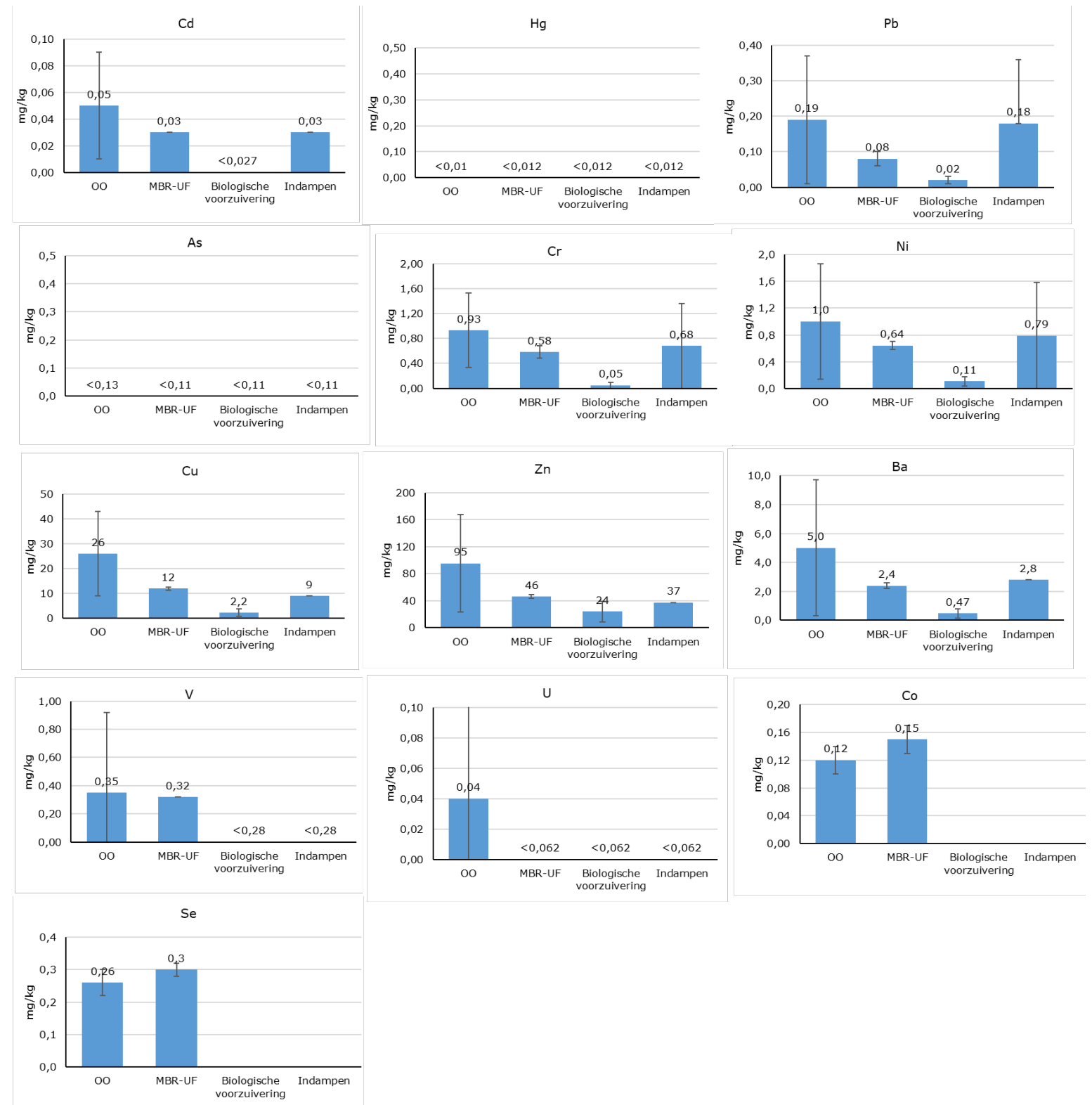

Figuur 3.2 Gemiddelde concentraties en variaties (plus en min 1 x standaarddeviatie) van zware metalen in het ingangsmateriaal van vier verschillende mvi's.

De ingangsmaterialen van de OO-, MBR-UF en indampinstallaties zijn wat betreft de concentraties zware metalen nagenoeg aan elkaar gelijk. In de ruwe varkensmest zijn de meeste zware metalen in meetbare concentraties aangetroffen. De drie hoogste gehalten zijn gevonden voor zink, koper en barium. De gemeten concentraties aan metalen in de ruwe varkensmest komen goed overeen met de concentraties die in eerder onderzoek zijn gemeten (Hoeksma et al, 2011).

Het ingangsmateriaal van de kalvergiervoorzuiveringsinstallaties verschilt wat zware metalen betreft over het algemeen niet significant van dat van de OO- en MBR-UF-installaties; in de kalvergier zijn de gehalten van de gedetecteerde metalen in het algemeen wel een fractie lager dan in de varkensdrijfmest en het digestaat. Referentiewaarden voor zware metalen in kalvergier zijn niet beschikbaar. 
Gemiddelde concentraties van antibiotica en hormoonstoffen in het ingangsmateriaal van de 4 typen MVI's. De waarden boven de detectiegrens zijn vet gedrukt. Betekenis van de letters in superscript: verschillende letters per regel betekent dat voor de betreffende parameter het verschil in concentratie in vergelijking met het ingangsmateriaal van oO significant is ( $P$ $<0,05)$. Tussen haakjes staat het aantal waarnemingen boven de detectiegrens gevolgd door het totale aantal waarnemingen.

\begin{tabular}{|c|c|c|c|c|c|c|c|c|c|c|c|c|}
\hline \multirow[b]{2}{*}{ Hormoonstoffen } & \multirow[t]{2}{*}{ Eenheid } & \multicolumn{3}{|c|}{ ००* } & \multicolumn{2}{|c|}{ MBR-UF* } & \multicolumn{3}{|c|}{$\begin{array}{l}\text { Biologische } \\
\text { voorzuivering } \\
\text { kalvergier** }\end{array}$} & \multicolumn{3}{|c|}{ Indampen $* * *$} \\
\hline & & & & & & & & & & & & \\
\hline ER-CALUX & ng $17 ß \mathrm{EEQ} / \mathrm{g}$ & 16 & a & $(2 / 2)$ & 9,5 & ab $(4 / 4)$ & 0,37 & $\mathrm{~b}$ & $(4 / 4)$ & 1,8 & $\mathrm{~b}$ & $(2 / 2)$ \\
\hline \multicolumn{13}{|l|}{ Antibiotica } \\
\hline Oxytetracycline & $\mu \mathrm{g} / \mathrm{kg}$ & 217 & a & $(12 / 12)$ & 89 & a $(5 / 5)$ & 1954 & $\mathrm{~b}$ & $(13 / 13)$ & $<10$ & c & $(0 / 2)$ \\
\hline Doxycycline & $\mu \mathrm{g} / \mathrm{kg}$ & 345 & a & $(11 / 12)$ & 155 & a $(5 / 5)$ & 1379 & $\mathrm{~b}$ & $(13 / 13)$ & 75 & a & $(2 / 2)$ \\
\hline Sulfadiazine & $\mu \mathrm{g} / \mathrm{kg}$ & 5,8 & a & $(6 / 12)$ & 15 & a $(4 / 5)$ & 61 & $\mathrm{~b}$ & $(13 / 13)$ & 21 & ba & $(2 / 2)$ \\
\hline Sulfadimidine & $\mu \mathrm{g} / \mathrm{kg}$ & $<1$ & a & $(0 / 12)$ & $<1$ & ${ }^{a} \quad(0 / 5)$ & 43 & b & $(13 / 13)$ & $<1$ & a & $(0 / 2)$ \\
\hline Trimethoprim & $\mu \mathrm{g} / \mathrm{kg}$ & $<1,5$ & a & $(0 / 12)$ & $<1,4$ & a $(0 / 5)$ & $<1,8$ & $\mathrm{a}$ & $(0 / 13)$ & $<2$ & a & $(0 / 2)$ \\
\hline Ciprofloxacine & $\mu \mathrm{g} / \mathrm{kg}$ & $<5,7$ & a & $(0 / 12)$ & $<5,4$ & a $(0 / 5)$ & 0,77 & $\mathrm{~b}$ & $(4 / 13)$ & $<13$ & a & $(0 / 2)$ \\
\hline Enrofloxacine & $\mu \mathrm{g} / \mathrm{kg}$ & $<8,4$ & a & $(0 / 12)$ & $<6,6$ & a $(0 / 5)$ & $<5,6$ & $\mathrm{a}$ & $(0 / 13)$ & $<30$ & a & $(0 / 2)$ \\
\hline Flumequine & $\mu \mathrm{g} / \mathrm{kg}$ & 6,3 & a & $(3 / 12)$ & $<1,2$ & b $(0 / 5)$ & 412 & c & $(13 / 13)$ & 3,5 & a & $(2 / 2)$ \\
\hline Lincomycine & $\mu \mathrm{g} / \mathrm{kg}$ & $<1,75$ & a & $(0 / 12)$ & $<1,8$ & a $(0 / 5)$ & $<2,2$ & a & $(0 / 13)$ & $<7,5$ & $\mathrm{a}$ & $(0 / 2)$ \\
\hline Tilmicosine & $\mu \mathrm{g} / \mathrm{kg}$ & 1,3 & a & $(4 / 12)$ & 0,6 & a $(1 / 5)$ & 135 & $\mathrm{~b}$ & $(13 / 13)$ & $<2,5$ & c & $(0 / 2)$ \\
\hline Florfenicol & $\mu \mathrm{g} / \mathrm{kg}$ & $<1,7$ & a & $(0 / 12)$ & $<1,8$ & a $(0 / 5)$ & $<1,1$ & a & $(0 / 13)$ & $<1$ & a & $(0 / 2)$ \\
\hline Chloortetracycline & $\mu \mathrm{g} / \mathrm{kg}$ & 3,7 & a & $(1 / 7)$ & $<7,5$ & a $(0 / 2)$ & 24 & a & $(4 / 9)$ & $<15$ & a & $(0 / 2)$ \\
\hline Tetracycline & $\mu \mathrm{g} / \mathrm{kg}$ & 1 & a & $(1 / 7)$ & $<5$ & b $(0 / 2)$ & 16 & $a$ & $(8 / 9)$ & $<13$ & $\mathrm{~b}$ & $(0 / 2)$ \\
\hline Minocycline & $\mu \mathrm{g} / \mathrm{kg}$ & $<30$ & a & $(0 / 7)$ & $<25$ & a $(0 / 2)$ & $<23$ & a & $(0 / 9)$ & $<45$ & a & $(0 / 2)$ \\
\hline Methacycline & $\mu \mathrm{g} / \mathrm{kg}$ & $<22$ & a & $(0 / 7)$ & $<10$ & a $(0 / 2)$ & $<10$ & a & $(0 / 9)$ & $<18$ & a & $(0 / 2)$ \\
\hline Sulfathiazol & $\mu \mathrm{g} / \mathrm{kg}$ & $<4$ & a & $(0 / 7)$ & $<7,5$ & ${ }^{a} \quad(0 / 2)$ & $<3,2$ & a & $(0 / 9)$ & $<5$ & a & $(0 / 2)$ \\
\hline Sulfapyridine & $\mu \mathrm{g} / \mathrm{kg}$ & $<1,4$ & a & $(0 / 7)$ & $<3$ & a $(0 / 2)$ & $<2,3$ & a & $(0 / 9)$ & $<3$ & a & $(0 / 2)$ \\
\hline Sulfamerazine & $\mu \mathrm{g} / \mathrm{kg}$ & $<1,1$ & a & $(0 / 7)$ & $<1$ & a $(0 / 2)$ & $<1$ & $\mathrm{a}$ & $(0 / 9)$ & $<1$ & a & $(0 / 2)$ \\
\hline Sulfamoxol & $\mu \mathrm{g} / \mathrm{kg}$ & $<1,4$ & a & $(0 / 7)$ & $<1$ & ${ }^{a}(0 / 2)$ & $<1,1$ & a & $(0 / 9)$ & $<1,5$ & a & $(0 / 2)$ \\
\hline Sulfamethizol & $\mu \mathrm{g} / \mathrm{kg}$ & $<2$ & a & $(0 / 7)$ & $<1$ & a $(0 / 2)$ & $<1,2$ & a & $(0 / 9)$ & $<1,5$ & a & $(0 / 2)$ \\
\hline Sulfamethoxypyridazine & $\mu \mathrm{g} / \mathrm{kg}$ & $<1$ & a & $(0 / 7)$ & $<1$ & a $(0 / 2)$ & $<1$ & a & $(0 / 9)$ & $<1$ & a & $(0 / 2)$ \\
\hline Sulfamonomethoxine & $\mu \mathrm{g} / \mathrm{kg}$ & $<2,3$ & a & $(0 / 7)$ & $<1$ & a $(0 / 2)$ & $<1,2$ & a & $(0 / 9)$ & $<1,5$ & a & $(0 / 2)$ \\
\hline Sulfachloorpyridazine & $\mu \mathrm{g} / \mathrm{kg}$ & $<2,7$ & a & $(0 / 7)$ & $<2$ & a $(0 / 2)$ & $<2,3$ & $\mathrm{a}$ & $(0 / 9)$ & $<3$ & a & $(0 / 2)$ \\
\hline Sulfadoxine & $\mu \mathrm{g} / \mathrm{kg}$ & $<1,1$ & a & $(0 / 7)$ & $<1$ & a $(0 / 2)$ & $<1$ & a & $(0 / 9)$ & $<1$ & a & $(0 / 2)$ \\
\hline Sulfamethoxazol & $\mu \mathrm{g} / \mathrm{kg}$ & $<1,4$ & a & $(0 / 7)$ & $<1$ & ${ }^{a} \quad(0 / 2)$ & $<1,3$ & a & $(0 / 9)$ & $<1,5$ & a & $(0 / 2)$ \\
\hline Sulfisoxazol & $\mu \mathrm{g} / \mathrm{kg}$ & $<2,4$ & a & $(0 / 7)$ & $<2$ & a $(0 / 2)$ & $<1,7$ & $\mathrm{a}$ & $(0 / 9)$ & $<2,5$ & a & $(0 / 2)$ \\
\hline Sulfadimethoxine & $\mu \mathrm{g} / \mathrm{kg}$ & $<1,3$ & a & $(0 / 7)$ & $<1$ & ${ }^{a} \quad(0 / 2)$ & $<1,2$ & a & $(0 / 9)$ & $<1$ & a & $(0 / 2)$ \\
\hline Sulfaquinoxaline & $\mu \mathrm{g} / \mathrm{kg}$ & $<3,6$ & a & $(0 / 7)$ & $<2$ & a $(0 / 2)$ & $<1,4$ & $\mathrm{a}$ & $(0 / 9)$ & $<2,5$ & a & $(0 / 2)$ \\
\hline Sulfacetamide & $\mu \mathrm{g} / \mathrm{kg}$ & $<1,1$ & a & $(0 / 7)$ & $<1$ & a $(0 / 2)$ & $<1$ & a & $(0 / 9)$ & $<1$ & a & $(0 / 2)$ \\
\hline Sulfaphenazol & $\mu \mathrm{g} / \mathrm{kg}$ & $<12$ & a & $(0 / 7)$ & $<10$ & ${ }^{a}(0 / 2)$ & $<10$ & a & $(0 / 9)$ & $<13$ & a & $(0 / 2)$ \\
\hline Dapson & $\mu \mathrm{g} / \mathrm{kg}$ & $<1,1$ & a & $(0 / 7)$ & $<1$ & a $(0 / 2)$ & $<1$ & a & $(0 / 9)$ & $<1$ & a & $(0 / 2)$ \\
\hline Marbofloxacine & $\mu \mathrm{g} / \mathrm{kg}$ & $<7,8$ & a & $(0 / 7)$ & $<7,5$ & a $(0 / 2)$ & 1 & a & $(2 / 9)$ & $<10$ & a & $(0 / 2)$ \\
\hline Norfloxacine & $\mu \mathrm{g} / \mathrm{kg}$ & $<21$ & a & $(0 / 7)$ & $<12,5$ & a $(0 / 2)$ & $<12$ & a & $(0 / 9)$ & $<23$ & a & $(0 / 2)$ \\
\hline Danofloxacine & $\mu \mathrm{g} / \mathrm{kg}$ & $<16$ & a & $(0 / 7)$ & $<12,5$ & a $(0 / 2)$ & $<8,8$ & a & $(0 / 9)$ & $<28$ & a & $(0 / 2)$ \\
\hline Sarafloxacine & $\mu \mathrm{g} / \mathrm{kg}$ & $<20$ & a & $(0 / 7)$ & $<25$ & ${ }^{a} \quad(0 / 2)$ & $<12$ & a & $(0 / 9)$ & $<50$ & a & $(0 / 2)$ \\
\hline Difloxacine & $\mu \mathrm{g} / \mathrm{kg}$ & $<11$ & a & $(0 / 7)$ & $<10$ & a $(0 / 2)$ & $<5,3$ & a & $(0 / 9)$ & $<25$ & a & $(0 / 2)$ \\
\hline Oxolinezuur & $\mu \mathrm{g} / \mathrm{kg}$ & $<7$ & a & $(0 / 7)$ & $<4$ & a $(0 / 2)$ & $<3,9$ & a & $(0 / 9)$ & $<10$ & a & $(0 / 2)$ \\
\hline Nalidixinezuur & $\mu \mathrm{g} / \mathrm{kg}$ & $<8,4$ & a & $(0 / 7)$ & $<2$ & a $(0 / 2)$ & $<3,8$ & a & $(0 / 9)$ & $<5$ & a & $(0 / 2)$ \\
\hline Levofloxacin/ofloxacin & $\mu \mathrm{g} / \mathrm{kg}$ & $<8,6$ & a & $(0 / 7)$ & $<5$ & a $(0 / 2)$ & $<4,3$ & a & $(0 / 9)$ & $<10$ & a & $(0 / 2)$ \\
\hline
\end{tabular}




\begin{tabular}{|c|c|c|c|c|c|c|c|c|c|c|c|c|}
\hline \multirow{2}{*}{$\begin{array}{l}\text { Parameter } \\
\text { Trovafloxacin }\end{array}$} & \multirow{2}{*}{$\begin{array}{l}\text { Eenheid } \\
\qquad \mu \mathrm{g} / \mathrm{kg}\end{array}$} & \multicolumn{3}{|c|}{ ००* } & \multicolumn{2}{|c|}{ MBR-UF* } & \multicolumn{3}{|c|}{$\begin{array}{l}\text { Biologische } \\
\text { voorzuivering } \\
\text { kalvergier** }\end{array}$} & \multicolumn{3}{|c|}{ Indampen $* * *$} \\
\hline & & $<4,9$ & $\mathrm{a}$ & $(0 / 7)$ & $<4$ & a $(0 / 2)$ & $<1,8$ & a & $(0 / 9)$ & $<10$ & $a$ & $(0 / 2)$ \\
\hline Erythromycine & $\mu \mathrm{g} / \mathrm{kg}$ & $<24$ & $\mathrm{a}$ & $(0 / 7)$ & $<5$ & a $(0 / 2)$ & $<16$ & a & $(0 / 9)$ & $<4$ & $\mathrm{a}$ & $(0 / 2)$ \\
\hline Tylosine & $\mu \mathrm{g} / \mathrm{kg}$ & 4,7 & a & $(6 / 7)$ & 5,5 & a $(2 / 2)$ & $<22$ & $\mathrm{~b}$ & $(0 / 9)$ & $<2$ & $\mathrm{~b}$ & $(0 / 2)$ \\
\hline Josamycine & $\mu \mathrm{g} / \mathrm{kg}$ & $<2,4$ & $\mathrm{a}$ & $(0 / 7)$ & $<1$ & a $(0 / 2)$ & $<12$ & a & $(0 / 9)$ & $<1$ & $\mathrm{a}$ & $(0 / 2)$ \\
\hline Spiramycine & $\mu \mathrm{g} / \mathrm{kg}$ & $<9,3$ & $\mathrm{a}$ & $(0 / 7)$ & $<5$ & ${ }^{a}(0 / 2)$ & $<9,4$ & a & $(0 / 9)$ & $<10$ & a & $(0 / 2)$ \\
\hline Neospiramycine 1 & $\mu \mathrm{g} / \mathrm{kg}$ & $<8$ & $\mathrm{a}$ & $(0 / 7)$ & $<2,5$ & a $(0 / 2)$ & $<6,4$ & a & $(0 / 9)$ & $<3,5$ & $\mathrm{a}$ & $(0 / 2)$ \\
\hline Tiamulin & $\mu \mathrm{g} / \mathrm{kg}$ & 12 & $\mathrm{a}$ & $(2 / 7)$ & $<2$ & b $(0 / 2)$ & $<3,5$ & $\mathrm{~b}$ & $(0 / 9)$ & $<5$ & $\mathrm{~b}$ & $(0 / 2)$ \\
\hline Tulathromycine & $\mu \mathrm{g} / \mathrm{kg}$ & $<11$ & $\mathrm{a}$ & $(0 / 7)$ & $<1$ & a $(0 / 2)$ & 1,1 & a & $(6 / 9)$ & $<1$ & $a$ & $(0 / 2)$ \\
\hline Pirlimycine & $\mu \mathrm{g} / \mathrm{kg}$ & $<2$ & $\mathrm{a}$ & $(0 / 7)$ & $<1$ & a $(0 / 2)$ & $<2,7$ & a & $(0 / 9)$ & $<1$ & $\mathrm{a}$ & $(0 / 2)$ \\
\hline Valnemulin & $\mu \mathrm{g} / \mathrm{kg}$ & $<2,4$ & $\mathrm{a}$ & $(0 / 7)$ & $<1$ & a $(0 / 2)$ & $<1,4$ & a & $(0 / 9)$ & $<2$ & $a$ & $(0 / 2)$ \\
\hline Tylvalosine & $\mu \mathrm{g} / \mathrm{kg}$ & $<2,7$ & $\mathrm{a}$ & $(0 / 7)$ & $<1$ & a $(0 / 2)$ & $<2,8$ & a & $(0 / 9)$ & $<2$ & a & $(0 / 2)$ \\
\hline Natamycin & $\mu \mathrm{g} / \mathrm{kg}$ & $<12$ & a & $(0 / 7)$ & $<2$ & a $(0 / 2)$ & $<11$ & a & $(0 / 9)$ & $<1,5$ & a & $(0 / 2)$ \\
\hline Gamithromycine & $\mu \mathrm{g} / \mathrm{kg}$ & $<2,1$ & a & $(0 / 7)$ & $<1$ & a $(0 / 2)$ & $<2,4$ & a & $(0 / 9)$ & $<1,5$ & a & $(0 / 2)$ \\
\hline Tildipirosine & $\mu \mathrm{g} / \mathrm{kg}$ & $<7,3$ & $\mathrm{a}$ & $(0 / 7)$ & $<5$ & a $(0 / 2)$ & $<1$ & a & $(0 / 9)$ & $<3$ & a & $(0 / 2)$ \\
\hline Vancomycine & $\mu \mathrm{g} / \mathrm{kg}$ & $<14$ & $\mathrm{a}$ & $(0 / 7)$ & $<4$ & a $(0 / 2)$ & $<18$ & a & $(0 / 9)$ & $<4$ & a & $(0 / 2)$ \\
\hline Azithromycine & $\mu \mathrm{g} / \mathrm{kg}$ & $<2,6$ & $\mathrm{a}$ & $(0 / 7)$ & $<1$ & a $(0 / 2)$ & $<1,3$ & a & $(0 / 9)$ & $<1$ & a & $(0 / 2)$ \\
\hline Clarithromycine & $\mu \mathrm{g} / \mathrm{kg}$ & $<2,6$ & $\mathrm{a}$ & $(0 / 7)$ & $<1$ & a $(0 / 2)$ & $<4,1$ & a & $(0 / 9)$ & $<1$ & a & $(0 / 2)$ \\
\hline Dit betreft va & t van voornam & lee & 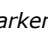 & 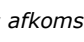 & & & & & & & & \\
\hline Dit betreft kal & mstia van mee & hed & & & & & & & & & & \\
\hline
\end{tabular}



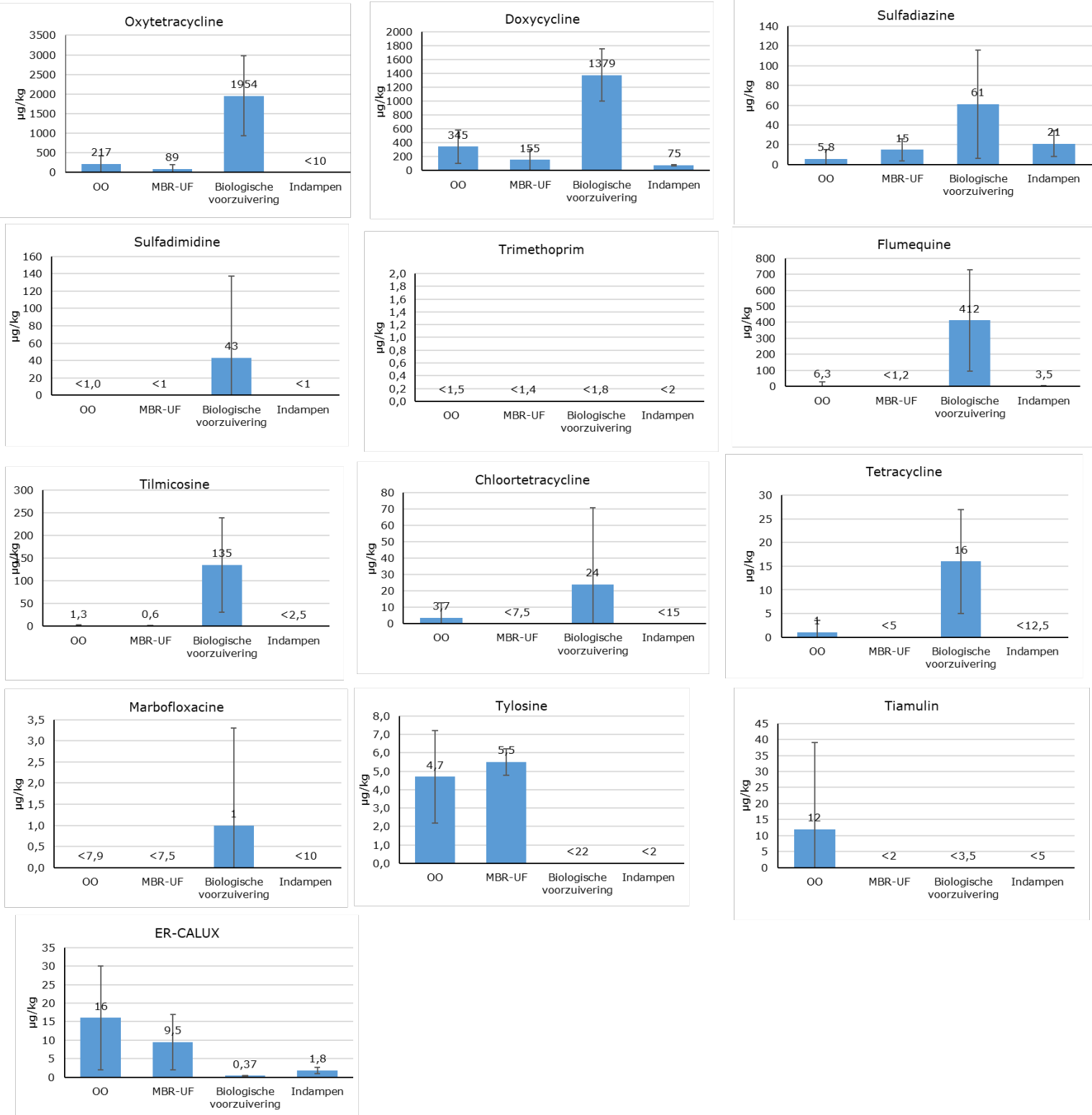

Figuur 3.3 Gemiddelde concentraties en variaties (plus en min 1 x standaarddeviatie) van antibiotica en hormoonstoffen (ER-CALUX) in het ingangsmateriaal van vier verschillende mvi's. Alleen parameters met minimaal één reële waarde zijn in de figuur weergegeven.

De ingangsmaterialen van de OO- en MBR-UF installaties lijken wat betreft de aangetroffen antibiotica sterk op elkaar. In beide zijn in volgorde van toenemende concentratie doxycycline, oxytetracycline, sulfadiazine, tylosine en tilmicosine gevonden. In één monster van het ingangsmateriaal van 00 werden daarnaast nog chloortetracycline, tiamulin en tetracycline in meetbare concentraties aangetroffen. In het ingangsmateriaal van indampen (digestaat) werden uitsluitend doxycycline, sulfadiazine en flumequine gedetecteerd.

De gevonden gemiddelde concentraties oxytetracycline, sulfadiazine en flumequine liggen in dezelfde range als de waarden die Lahr et al (2014) hebben gemeten in ruwe varkensmest van 4 OOinstallaties. De door deze onderzoekers gerapporteerde concentraties voor doxycycline waren grofweg een factor 10 hoger dan de gemiddelde concentratie in dit onderzoek.

De aangetroffen antibiotica in de ruwe varkensmest mochten worden verwacht gezien de gebruikte hoeveelheden van deze middelen in de varkenshouderij. Behalve tiamulin zijn genoemde antibiotica ook in de ruwe kalvergier gevonden, en wel in aanzienlijk hogere concentraties dan in de ruwe varkensmest. De kalvergier bevat daarnaast een relatief hoge concentratie flumequine, wat gezien het veelvuldig gebruik van dit antibioticum in de kalverhouderij te verwachten was (Lahr et al, 2019). 
Gemiddelde concentraties en standardafwijking van micro-organismen in het ingangsmateriaal van de 4 typen MVI's. Tussen haakjes staat het aantal positieve waarnemingen en het totale aantal waarnemingen. Voor berekening van de gemiddelde concentratie is voor monsters met waarnemingen onder de detectielimiet deze limiet aangenomen. De eenheid is de decadische logaritme van de concentratie in $\mathrm{KVE} / \mathrm{g}(\log 10(\mathrm{KVE} / \mathrm{g}))$, de gemiddelden zijn dus geometrisch gemiddelden van de concentraties op niet-logaritmische schaal. Enkele voorbeelden: Een waarde van +4 staat gelijk aan $10^{4}$ of te wel $10.000 \mathrm{KVE} / \mathrm{g}$, een waarde van 0 staat gelijk aan $10^{\circ}$ of te wel $1 \mathrm{KVE} / \mathrm{g}$. Betekenis van de letters in superscript: verschillende letters per regel betekent dat het verschil in concentratie in vergelijking met het ingangsmateriaal van 00 significant is $(p<0,05)$.

\begin{tabular}{|c|c|c|c|c|c|c|c|c|c|c|}
\hline \multirow[b]{2}{*}{ E. coli } & \multirow{2}{*}{$\begin{array}{c}00 \\
4,65\end{array}$} & \multicolumn{5}{|c|}{ MBR-UF } & \multicolumn{2}{|c|}{$\begin{array}{l}\text { Biologische voorzuivering } \\
\text { kalvergier }\end{array}$} & \multicolumn{2}{|c|}{ Indampen* } \\
\hline & & 0,22 & a $(5 / 5)$ & 4,07 & 0,03 & a $(3 / 3)$ & 4,79 & $0,21 \times(4 / 4)$ & 5,72 & $(1 / 1)$ \\
\hline Enterokokken & 4,59 & 0,14 & a $(5 / 5)$ & 4,33 & 0,19 & a $(3 / 3)$ & 6,54 & 0,31 b $(4 / 4)$ & 4,94 & $(1 / 1)$ \\
\hline Sporen van sulfietreducerende Clostridia & 4,85 & 0,14 & a $(5 / 5)$ & 5,00 & 0,12 & a $(3 / 3)$ & 4,20 & 0,18 b $(4 / 4)$ & 4,97 & $(1 / 1)$ \\
\hline Sporen van C. difficile & 1,97 & 0,20 & a $(5 / 5)$ & 1,49 & 0,29 & a $(3 / 3)$ & 1,48 & 0,16 a $(4 / 4)$ & 2,65 & $(1 / 1)$ \\
\hline ESBL E. coli & 0,62 & 0,39 & a $(1 / 5)$ & 1,29 & 0,33 & a $(1 / 3)$ & 2,31 & 0,09 b $(1 / 4)$ & 3,68 & $(1 / 1)$ \\
\hline Bacteriofagen & 5,44 & 0,08 & a $(3 / 3)$ & 4,69 & 0,08 & b $(2 / 2)$ & NA & & NA & \\
\hline Campylobacter & Aanwezig & & $(3 / 3)$ & Aanwezig & & $(1 / 1)$ & Afwezig & $(0 / 4)$ & Aanwezig & $(1 / 1)$ \\
\hline MRSA & Afwezig & & $(0 / 3)$ & Afwezig & & $(0 / 2)$ & Aanwezig & $(1 / 4)$ & Aanwezig & $(1 / 1)$ \\
\hline Hepatitis E virus & Aanwezig & & $(3 / 3)$ & Aanwezig & & $(1 / 2)$ & NA & & NA & \\
\hline
\end{tabular}

* Dit ingangsmateriaal betreft ruwe mest, vóór vergisting

NA niet onderzocht 

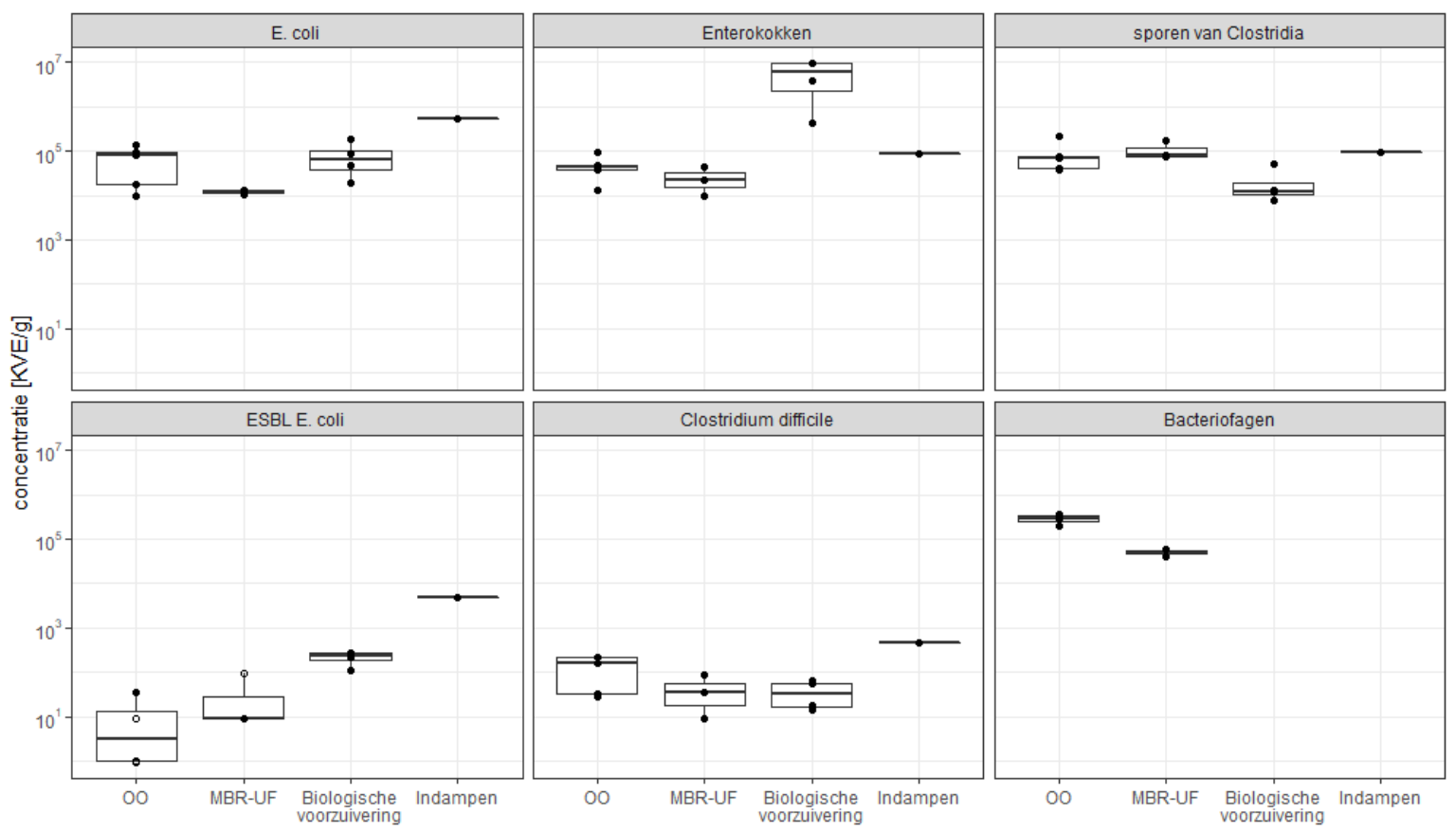

Figuur 3.4 Concentraties en hun variatie (mediaan als horizontale lijn, 25-75 percentiel als box, uitschieters als punten met een verticale verbinding naar de box) van micro-organismen in de ruwe mest van vier typen MVI's. Waarden onder de detectielimiet zijn vervangen door de detectielimiet en met open symbolen aangeduid, waarden boven de detectielimiet zijn door gevulde symbolen aangeduid.

Tabel 6 en Figuur 3.4 tonen dat de concentraties van de micro-organismen in de ruwe varkensmest (van OO, MBR-UF en indampen) over het algemeen redelijk overeenkomen. Hoeksma et al (2015) vonden vergelijkbare concentraties $E$. coli, enterokokken, ESBL E. coli en bacteriofagen. Kalvergier laat significant hogere concentraties zien van enterokokken en ESBL $E$. coli en lagere concentraties van sporen van Clostridia. ESBL $E$. coli werden alleen in enkele monsters in het ingaande materiaal gevonden (de significantie geeft dus vooral het verschil tussen de detectielimieten in de verschillende installaties aan). 


\subsection{Samenstelling van effluenten van MVI's}

Tabel 7 Gemiddelde gehalten van algemene chemische parameters in effluenten van de 4 typen MVI's. Betekenis van de letters in superscript: verschillende letters per regel betekent dat voor de betreffende parameter het verschil in gehalte in vergelijking met effluent van 00 significant is $(P<0,05)$. Tussen haakjes staat het aantal waarnemingen boven de detectiegrens gevolgd door het totale aantal waarnemingen.

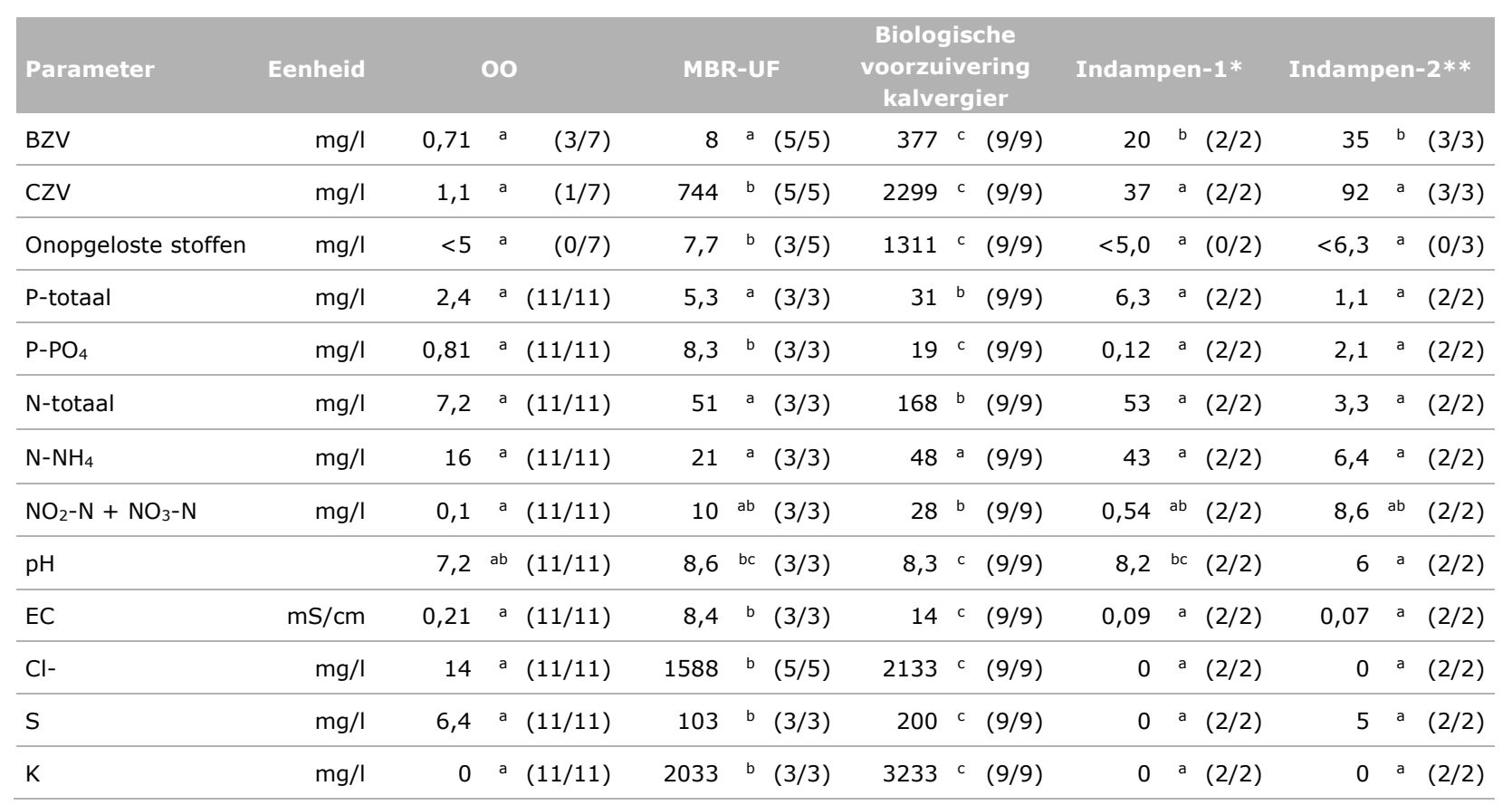

* Spuiwater, gemeten vóór OO en IW

** Gemeten ná OO en IW 

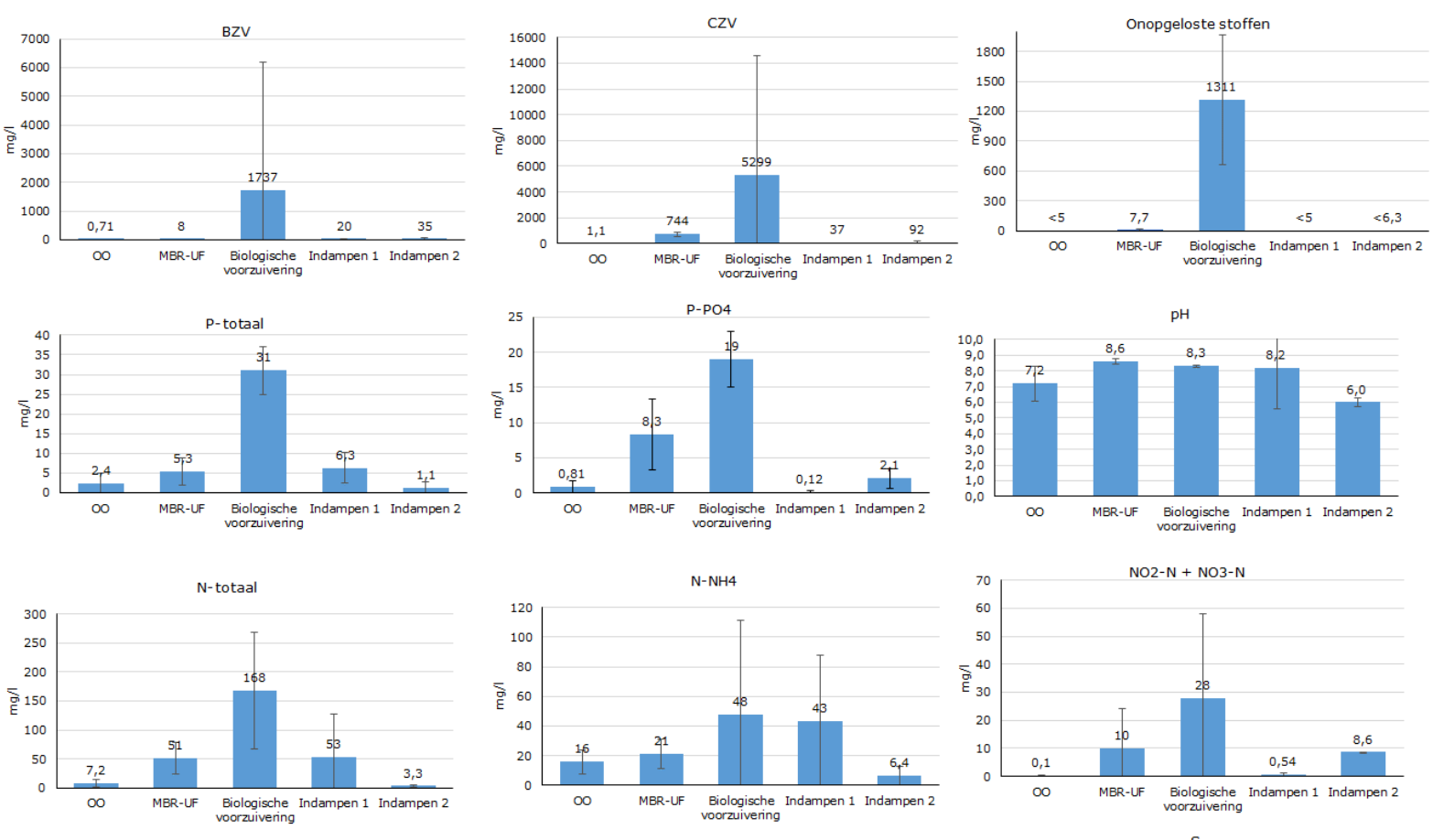

Cl-
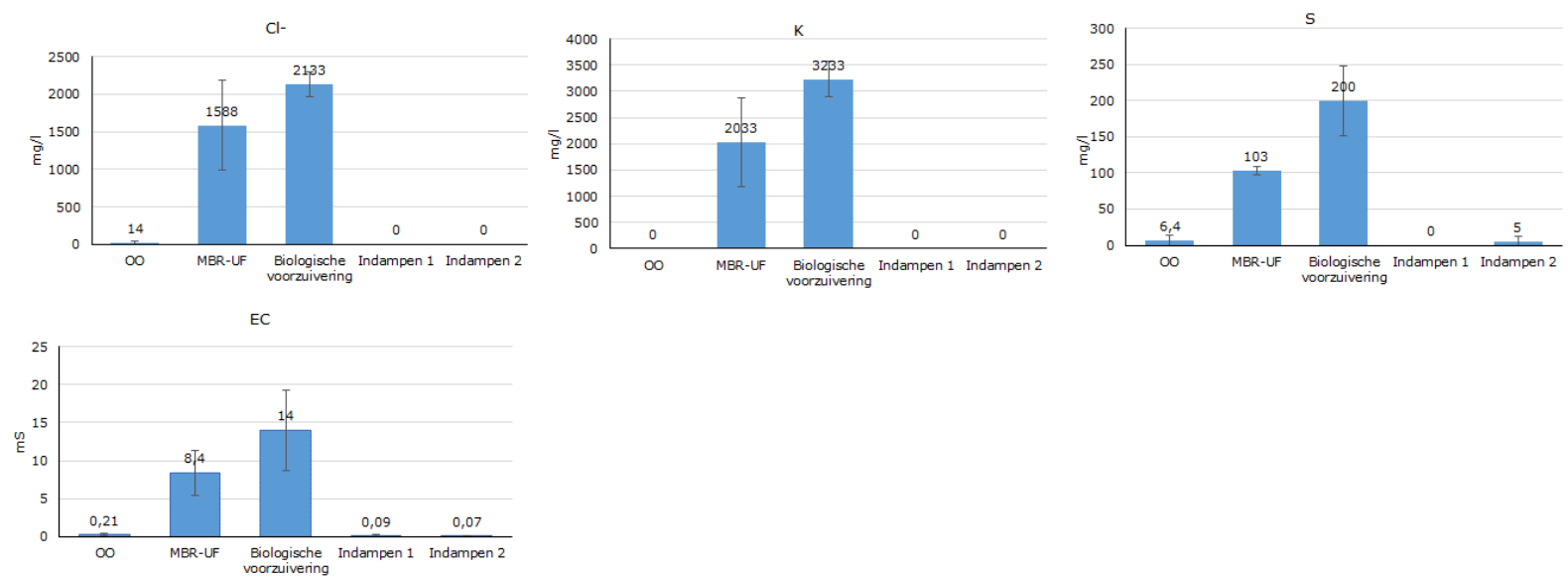

Figuur 3.5 Gemiddelde gehalten en variaties (plus en min 1 x standaarddeviatie) van algemene chemische parameters in het effluent van vier typen MVI's. Indampen-1 is gemeten vóór, indampen-2 ná OO en IW.

Tabel 7 en Figuur 3.5 laten zien dat de effluenten van indampen vóór en ná 00 en IW geen grote verschillen vertonen. Het grootste reducerend effect van $\mathrm{OO}$ en IW wordt, zoals verwacht, gevonden voor $\mathrm{N}$-totaal en $\mathrm{N}-\mathrm{NH}_{4}$. Ook de $\mathrm{pH}$ van het effluent is na deze behandeling duidelijk lager.

De effluenten van $\mathrm{OO}$ en indampen-2 zijn grosso modo gelijkwaardig wat betreft de algemene chemische parameters. In de effluenten van $O O$ en indampen- 2 zijn de gehalten van vrijwel alle parameters (niet BZV) lager dan in de effluenten van MBR-UF en biologische voorzuivering. De verschillen in gehalten tussen de effluenten van 00 en indampen- 2 enerzijds en die van MBR-UF anderzijds was te verwachten gezien het feit dat de eerste twee effluenten een uiterst fijn 00 filter $(0,1-1,0 \mathrm{~nm})$ en bovendien een ionenwisselaar hebben gepasseerd. Ze bevatten desondanks meetbare gehalten van de meeste algemene chemische parameters. In het effluent van $\mathrm{OO}$ is het gemiddelde $\mathrm{N}-\mathrm{NH}_{4}$ gehalte hoger dan het gemiddelde $\mathrm{N}$-totaal gehalte, wat opmerkelijk is. De verklaring hiervoor is dat bij enkele effluentmonsters bij de $\mathrm{N}$-totaal bepaling tegen de detectiegrens werd aangelopen terwijl dezelfde monsters een reële meetwaarde voor ammonium opleverden. Meetwaarden lager dan de rapportagegrens werden als nul beschouwd en meegenomen in de berekening van het gemiddelde gehalte. Opgemerkt wordt dat hierdoor mogelijk te lage gemiddelde $\mathrm{N}$-totaal gehalten worden gerapporteerd.

Het effluent van de biologische voorzuivering laat aanzienlijk hogere waarden van de algemene parameters zien dan de effluenten van de andere drie typen MVI's. Ook dit was te verwachten omdat 
de bewerking van kalvergier in een KGBI niet bedoeld is om een effluent te produceren dat op het oppervlaktewater kan worden geloosd, maar dat verder wordt gezuiverd in een RWZI.

Een OO membraan laat normaal gesproken geen ionen door, hooguit kleine vluchtige componenten zoals ammoniak. Dat er in het effluent van de betrokken 00 installaties toch een aantal stoffen in meetbare concentraties zijn aangetroffen kan mogelijk worden verklaard door slijtage of beschadiging van de membranen. Voorbehandeling van de ingaande mestvloeistof, reiniging en onderhoud verdienen daarom veel aandacht. De aangetroffen gehalten in het effluent van 00 zijn overigens vergelijkbaar met de gehalten die eerdere en recente onderzoeken laten zien (Hoeksma et al, 2011; Hoeksma en de Buisonjé, 2015; Hoeksma et al, 2021).

Tabel 8 Gemiddelde concentraties van zware metalen in effluenten van de 4 typen MVI's. Betekenis van de letters in superscript: verschillende letters per regel betekent dat het verschil in concentratie in vergelijking met effluent van OO significant is $(P<0,05)$. Tussen haakjes staat het aantal waarnemingen boven de detectiegrens gevolgd door het totale aantal waarnemingen.

\begin{tabular}{|c|c|c|c|c|c|c|c|}
\hline Parameter & Eenheid & or & 10 & MBR-UF & $\begin{array}{l}\text { Biologische } \\
\text { voorzuivering } \\
\text { kalvergier }\end{array}$ & Indampen-1* & Indampen-2** \\
\hline $\mathrm{Cd}$ & $\mathrm{mg} / \mathrm{l}$ & $<0,027$ & a $(0 / 11)$ & $<0,027$ a $(0 / 3)$ & $<0,027$ a $(0 / 6)$ & $<0,03$ a $(0 / 3)$ & $<0,03$ a $(0 / 1)$ \\
\hline $\mathrm{Hg}$ & $\mathrm{mg} / \mathrm{l}$ & $<0,012$ & a $(0 / 11)$ & $<0,012$ a $(0 / 3)$ & $<0,012$ a $(0 / 6)$ & 0,02 b $\quad(1 / 3)$ & $<0,01$ a $(0 / 1)$ \\
\hline $\mathrm{Pb}$ & $\mathrm{mg} / \mathrm{l}$ & $<0,013$ & a $(0 / 11)$ & $<0,013$ a $(0 / 3)$ & $<0,013$ a $(0 / 6)$ & 0,01 b $\quad(1 / 3)$ & $<0,01$ a $(0 / 1)$ \\
\hline As & $\mathrm{mg} / \mathrm{l}$ & $<0,11$ & a $(0 / 11)$ & $<0,11$ a $(0 / 3)$ & $<0,11$ a $(0 / 6)$ & $<0,11$ a $(0 / 3)$ & $<0,11$ a $(0 / 1)$ \\
\hline $\mathrm{Cr}$ & $\mathrm{mg} / \mathrm{l}$ & $<0,074$ & a $(0 / 11)$ & $<0,074$ a $(0 / 3)$ & $<0,074$ a $(0 / 6)$ & 1,9 b $(1 / 3)$ & $<0,07$ a $(0 / 1)$ \\
\hline $\mathrm{Ni}$ & $\mathrm{mg} / \mathrm{l}$ & 0,01 & a $(1 / 11)$ & 0,04 a $(1 / 3)$ & $0,02{ }^{a}(1 / 6)$ & 1,6 b $(1 / 3)$ & $<0,07 \quad$ c $(0 / 1)$ \\
\hline $\mathrm{Cu}$ & $\mathrm{mg} / \mathrm{l}$ & $<0,57$ & a $(0 / 11)$ & $<0,57$ a $(0 / 3)$ & 0,3 b $(1 / 6)$ & $<0,57$ a $(0 / 3)$ & $<0,57$ a $(0 / 1)$ \\
\hline $\mathrm{Zn}$ & $\mathrm{mg} / \mathrm{l}$ & $<1,1$ & a $(0 / 11)$ & $<1,1$ a $(0 / 3)$ & 4,0 b $(3 / 6)$ & 0,63 b $(1 / 3)$ & $<1,1$ a $(0 / 1)$ \\
\hline $\mathrm{Ba}$ & $\mathrm{mg} / \mathrm{l}$ & $<0,16$ & a $(0 / 11)$ & $<0,16$ a $(0 / 3)$ & 0,05 b $(1 / 6)$ & $<0,16$ a $(0 / 3)$ & $<0,16$ a $(0 / 1)$ \\
\hline v & $\mathrm{mg} / \mathrm{l}$ & $<0,28$ & a $\quad(0 / 9)$ & $<0,28$ a $(0 / 1)$ & $<0,28$ a $(0 / 6)$ & $<0,28$ a $(0 / 3)$ & $<0,28$ a $(0 / 1)$ \\
\hline U & $\mathrm{mg} / \mathrm{l}$ & $<0,06$ & a $\quad(0 / 9)$ & $<0,06$ a $(0 / 1)$ & $<0,06$ a $(0 / 6)$ & $<0,06$ a $(0 / 3)$ & $<0,06$ a $(0 / 1)$ \\
\hline Co & $\mathrm{mg} / \mathrm{l}$ & $<0,016$ & a $\quad(0 / 8)$ & $0,02 \quad b \quad(3 / 3)$ & $(0 / 0)$ & $(0 / 0)$ & $(0 / 0)$ \\
\hline $\mathrm{Se}$ & $\mathrm{mg} / \mathrm{l}$ & $<0,032$ & a $\quad(0 / 8)$ & $<0,032$ a $(0 / 3)$ & $(0 / 0)$ & $(0 / 0)$ & $(0 / 0)$ \\
\hline $\begin{array}{ll}* & \text { Spuiwa } \\
* * & \text { Gemete } \\
\text { NA } & \text { niet on }\end{array}$ & $\begin{array}{l}\text { jemeten vó } \\
\text { OO en IW } \\
\text { cht }\end{array}$ & DO en IW & & & & & \\
\hline
\end{tabular}



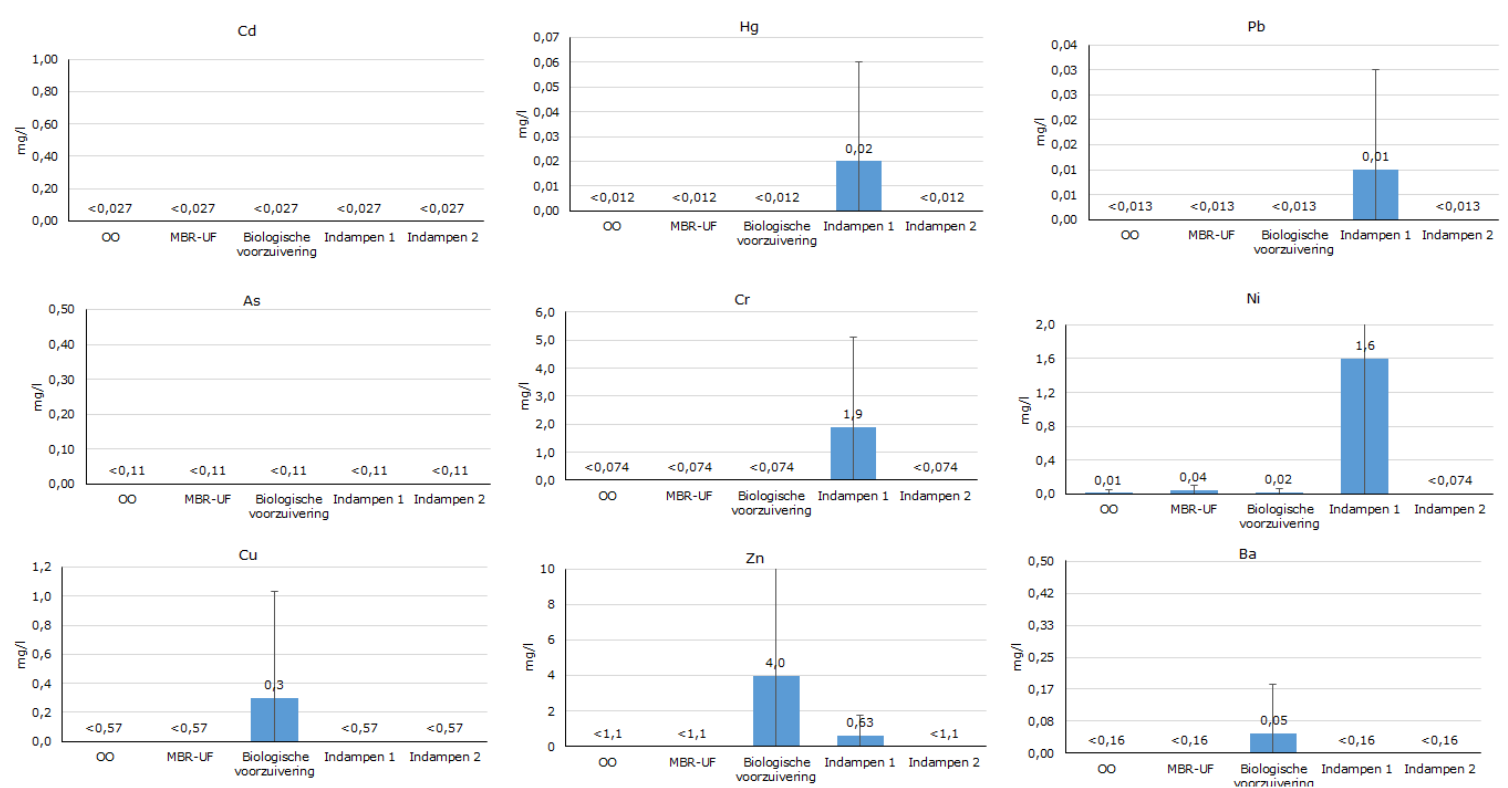

$\mathrm{v}$
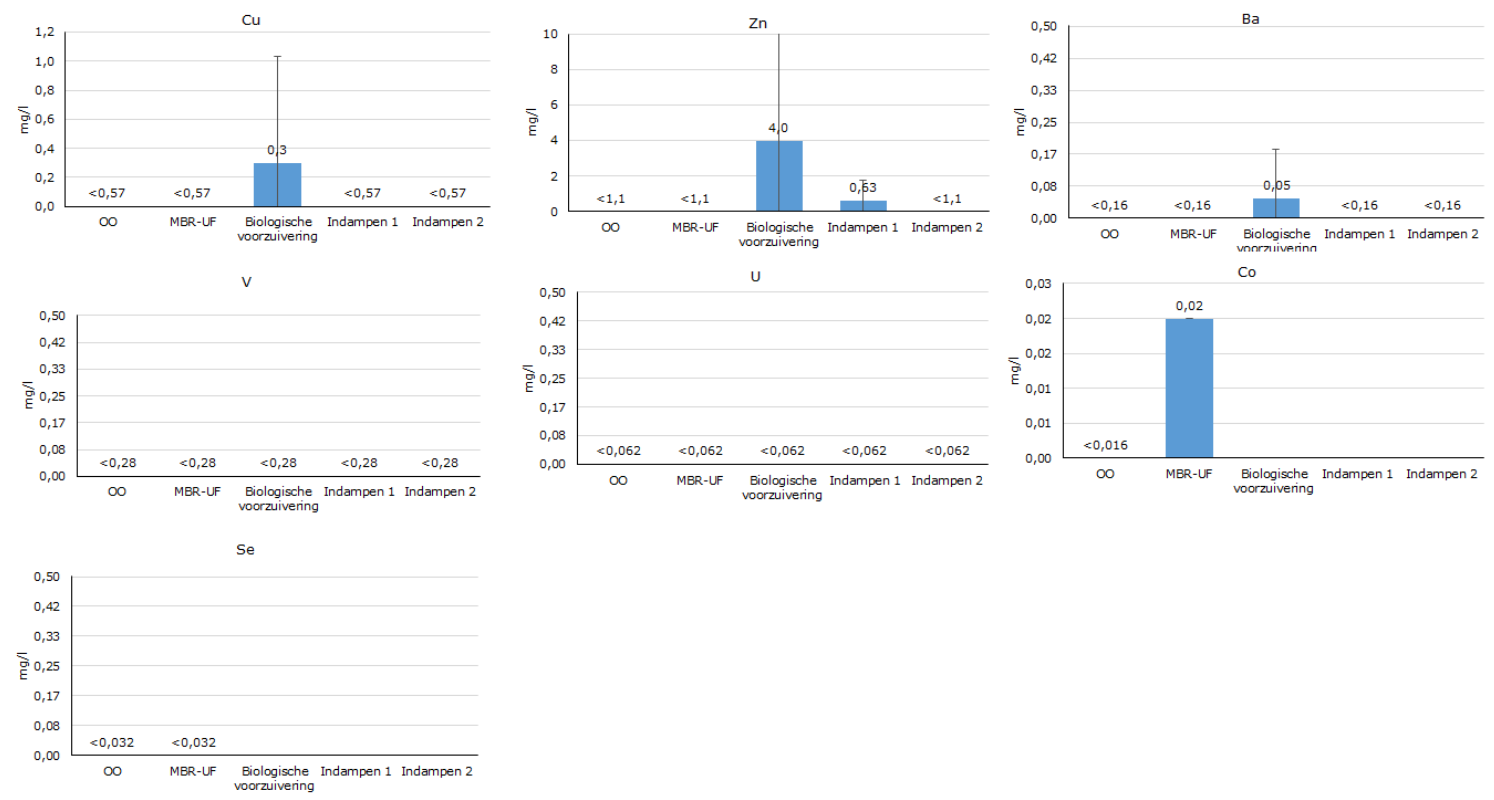

Figuur 3.6 Gemiddelde concentraties en variaties (plus en min 1 x standaarddeviatie) van zware metalen in het effluent van vier typen MVI's. Indampen-1 is gemeten vóór, indampen-2 ná OO en IW.

Veel van de meetwaarden van zware metalen zijn lager dan de detectiegrens van de toegepaste analysemethode. Deze was afgeleid van de methode die wordt toegepast bij gewasonderzoek, waarvan de detectiegrenzen hoger zijn dan van de methode voor wateronderzoek. Desondanks zijn in alle effluenten enkele meetbare gehalten van één of meer zware metalen aangetroffen, de meeste in het effluent van indampen-1, gemeten vóór 00 en IW. Opvallend in dit effluent zijn de relatief hoge concentraties van chroom en nikkel die evenals kwik, lood en zink in één enkel monster werden aangetroffen. In het monster van het effluent van indampen-2, gemeten ná OO en IW, kon geen van de zware metalen worden aangetoond.

In de effluenten van OO werden nikkel, van MBR-UF nikkel en kobalt en van de biologische voorzuivering nikkel, kobalt, koper en zink in meetbare concentraties aangetroffen. Deze metalen werden bij elke MVI in slechts één effluentmonster aangetroffen, met uitzondering van zink dat in 3 van de 6 monsters werd aangetoond.

De metaalgehalten in het effluent van MBR-UF (slechts 3 metingen) zijn vergelijkbaar met die in het effluent van $\mathrm{OO}$, terwijl in het effluent van MBR-UF hogere gehalten werden verwacht gezien de poriegrootte van een UF filter. Dit wijst erop dat zware metalen in sterke mate gebonden zijn aan slibdeeltjes. De meetresultaten voor zware metalen in het effluent van OO zijn vergelijkbaar met de resultaten van de monitoring die werd uitgevoerd in het kader van de pilot mineralenconcentraten (Hoeksma et al, 2011).

De conclusie kan zijn dat het effluent van MBR-UF wat zware metalen betreft gelijkwaardig is aan het effluent van 00 . 
De concentraties van de aangetroffen zware metalen in de effluenten van de 4 MVI's liggen alle boven de normwaarden voor oppervlaktewater, waarbij opgemerkt wordt dat een toets van de gemeten waarden aan de normwaarden voor oppervlaktewater niet goed mogelijk was, omdat de detectie- en rapportagegrenzen voor zware metalen aanzienlijk hoger waren dan de normwaarden.

Normwaarden voor zware metalen voor oppervlaktewater (jaargemiddelde concentratie voor langdurige blootstelling zijn gegeven in onderstaande tabel ${ }^{2}$ :

\begin{tabular}{lll} 
& $j \mathrm{G}-\mathrm{MKN}$ & Opmerking \\
$\mathrm{Cd}$ & $\mu \mathrm{g} / \mathrm{l}$ & Afhankelijk van waterhardheidsklasse \\
\hline $\mathrm{Hg}$ & 3,4 & $0,08-0,25$ \\
\hline $\mathrm{Pb}$ & 1,2 & 0,5 \\
\hline $\mathrm{As}$ & 3,4 & 4 \\
\hline $\mathrm{Cr}$ & 2,4 & 7,8 \\
\hline $\mathrm{Ni}$ & 73 & \\
\hline $\mathrm{Cu}$ & 3,5 & 0,17 \\
\hline $\mathrm{Bn}$ & 0,2 \\
\hline $\mathrm{V}$ & 0,052 \\
\hline $\mathrm{Co}$ &
\end{tabular}

\footnotetext{
${ }^{2}$ https://rvs.rivm.nl
} 
Gemiddelde concentraties van antibiotica en hormoonstoffen in de effluenten van de 4 typen MVI's. Waarden boven de detectiegrens zijn vetgedrukt. Betekenis van de letters in superscript: verschillende letters per regel betekent dat het verschil in concentratie in vergelijking met effluent van 00 significant is $(P<0,05)$. Tussen haakjes staat het aantal waarnemingen boven de detectiegrens gevolgd door het totale aantal waarnemingen.

\begin{tabular}{|c|c|c|c|c|c|c|c|c|c|c|c|c|c|}
\hline \multirow{2}{*}{ Parameter } & \multirow[t]{2}{*}{ Eenheid } & \multicolumn{2}{|c|}{ O० } & \multicolumn{2}{|c|}{ MBR-UF } & \multicolumn{2}{|c|}{$\begin{array}{l}\text { Biologische } \\
\text { voorzuivering } \\
\text { kalvergier }\end{array}$} & \multicolumn{3}{|c|}{ Indampen-1 $*$} & \multicolumn{3}{|c|}{$\begin{array}{c}\text { Indampen- } \\
\qquad 2 * *\end{array}$} \\
\hline & & & & & & & & & & & & & \\
\hline ER-CALUX & $g$ 17ß EEQ/g & $<0,000010$ & a $\quad(0 / 2)$ & 0,00028 & b $(2 / 4)$ & 0,00118 & $(3 / 4)$ & NA & & $(0 / 0)$ & 0,02 & b ( & $(2 / 2)$ \\
\hline \multicolumn{14}{|l|}{ Antibiotica } \\
\hline Oxytetracycline & $\mu g / l$ & 2,9 & a $(1 / 15)$ & $<1,6$ & b $(0 / 5)$ & 479 b & b $(15 / 15)$ & 1,3 & a & $(1 / 3)$ & $<8,0$ & b ( & $(0 / 3)$ \\
\hline Doxycycline & $\mu \mathrm{g} / \mathrm{l}$ & 4,5 & a $(1 / 15)$ & 1,2 & a $(2 / 5)$ & $312 b$ & b $(15 / 15)$ & 1 & a & $(1 / 3)$ & $<4,0$ & c ( & $(0 / 3)$ \\
\hline Sulfadiazine & $\mu g / l$ & 0,33 & a $(1 / 15)$ & $<1$ & b $(0 / 5)$ & 5,3 a & a $\quad(5 / 15)$ & $<1,0$ & $\mathrm{~b}$ & $(0 / 3)$ & $<1,0$ & b ( & $(0 / 3)$ \\
\hline Sulfadimidine & $\mu g / l$ & $<1$ & a $(0 / 15)$ & $<1$ & a $(0 / 5)$ & 2,8 & b $\quad(2 / 15)$ & $<1,0$ & a & $(0 / 3)$ & $<1,0$ & a ( & $(0 / 3)$ \\
\hline Trimethoprim & $\mu \mathrm{g} / \mathrm{l}$ & $<1,1$ & a $(0 / 15)$ & $<1$ & a $(0 / 5)$ & $<1 \quad a$ & a $\quad(0 / 15)$ & $<1,0$ & a & $(0 / 3)$ & $<1,0$ & ${ }^{\mathrm{a}}($ & $(0 / 3)$ \\
\hline Ciprofloxacine & $\mu \mathrm{g} / \mathrm{l}$ & $<2,1$ & a $(0 / 15)$ & $<1$ & a $(0 / 5)$ & $<1,1$ a & a $\quad(0 / 15)$ & 0,67 & $\mathrm{~b}$ & $(1 / 3)$ & $<1,0$ & a ( & $(0 / 3)$ \\
\hline Enrofloxacine & $\mu \mathrm{g} / \mathrm{l}$ & 0,13 & a $(2 / 15)$ & $<1,2$ & b $(0 / 5)$ & 0,13 & b $\quad(1 / 15)$ & 0,67 & a & $(1 / 3)$ & $<1,0$ & b ( & $(0 / 3)$ \\
\hline Flumequine & $\mu \mathrm{g} / \mathrm{l}$ & $<1$ & a $(0 / 15)$ & $<1$ & a $(0 / 5)$ & $195^{c}$ & c $(15 / 15)$ & 0,33 & $\mathrm{~b}$ & $(1 / 3)$ & $<1,0$ & a ( & $(0 / 3)$ \\
\hline Lincomycine & $\mu \mathrm{g} / \mathrm{l}$ & $<1,3$ & a $(0 / 15)$ & $<1$ & a $(0 / 5)$ & $<1,2$ a & a $\quad(0 / 15)$ & $<1,3$ & a & $(0 / 3)$ & $<1,0$ & a ( & $(0 / 3)$ \\
\hline Tilmicosine & $\mu g / l$ & $<26$ & a $(0 / 15)$ & $<20$ & a $(0 / 5)$ & $15 \mathrm{~b}$ & b $(14 / 15)$ & 0,67 & c & $(1 / 3)$ & 2,5 & $\mathrm{bc}($ & $(1 / 3)$ \\
\hline Florfenicol & $\mu \mathrm{g} / \mathrm{l}$ & $<1$ & a $(0 / 15)$ & $<1,2$ & a $(0 / 5)$ & $<1,1$ a & a $\quad(0 / 15)$ & $<1,0$ & a & $(0 / 3)$ & $<1,0$ & a ( & $(0 / 3)$ \\
\hline Chloortetracycline & $\mu \mathrm{g} / \mathrm{l}$ & $<7,5$ & a $(0 / 10)$ & $<1$ & a $(0 / 2)$ & 1,4 & b $\quad(1 / 10)$ & $<5,3$ & a & $(0 / 3)$ & $<6,7$ & & $(0 / 3)$ \\
\hline Tetracycline & $\mu \mathrm{g} / \mathrm{l}$ & $<3,1$ & a $(0 / 10)$ & $<1$ & a $(0 / 2)$ & $4,7 b$ & b $\quad(2 / 10)$ & $<2,0$ & a & $(0 / 3)$ & $<3,3$ & a ( & $(0 / 3)$ \\
\hline Minocycline & $\mu \mathrm{g} / \mathrm{l}$ & $<12$ & a $(0 / 10)$ & $<4$ & a $(0 / 2)$ & $<11$ a & a $\quad(0 / 10)$ & $<4,7$ & a & $(0 / 3)$ & $<12$ & a ( & $(0 / 3)$ \\
\hline Methacycline & $\mu \mathrm{g} / \mathrm{l}$ & $<5,9$ & a $(0 / 10)$ & $<1$ & a $(0 / 2)$ & $<4,2$ a & a $\quad(0 / 10)$ & $<2,7$ & a & $(0 / 3)$ & $<10$ & a ( & $(0 / 3)$ \\
\hline Sulfathiazol & $\mu \mathrm{g} / \mathrm{l}$ & $<1,4$ & a $(0 / 10)$ & $<2$ & a $(0 / 2)$ & $<1,8$ a & a $\quad(0 / 10)$ & $<1,0$ & a & $(0 / 3)$ & $<1,3$ & a ( & $(0 / 3)$ \\
\hline Sulfapyridine & $\mu g / l$ & $<1,2$ & a $(0 / 10)$ & $<1$ & a $(0 / 2)$ & $<1,1$ a & a $\quad(0 / 10)$ & $<1,0$ & a & $(0 / 3)$ & $<1,0$ & & $(0 / 3)$ \\
\hline Sulfamerazine & $\mu \mathrm{g} / \mathrm{l}$ & $<1$ & a $(0 / 10)$ & $<1$ & a $(0 / 2)$ & $<1{ }^{a}$ & a $\quad(0 / 10)$ & $<1,0$ & a & $(0 / 3)$ & $<1,0$ & a ( & $(0 / 3)$ \\
\hline Sulfamoxol & $\mu \mathrm{g} / \mathrm{l}$ & $<1,2$ & a $(0 / 10)$ & $<1$ & a $(0 / 2)$ & $<1 \quad a$ & a $\quad(0 / 10)$ & $<1,3$ & a & $(0 / 3)$ & $<1,0$ & & $(0 / 3)$ \\
\hline Sulfamethizol & $\mu \mathrm{g} / \mathrm{l}$ & $<1$ & a $(0 / 10)$ & $<1$ & a $(0 / 2)$ & $<1,1$ a & a $\quad(0 / 10)$ & $<1,0$ & a & $(0 / 3)$ & $<1,0$ & a ( & $(0 / 3)$ \\
\hline Sulfamethoxy-pyridazine & $\mu \mathrm{g} / \mathrm{l}$ & $<1$ & a $(0 / 10)$ & $<1$ & a $(0 / 2)$ & $<1 \quad a$ & a $\quad(0 / 10)$ & $<1,0$ & a & $(0 / 3)$ & $<1,0$ & a ( & $(0 / 3)$ \\
\hline Sulfamonomethoxine & $\mu \mathrm{g} / \mathrm{l}$ & $<1,1$ & a $(0 / 10)$ & $<1$ & a $(0 / 2)$ & $<1,1$ a & a $\quad(0 / 10)$ & $<1,0$ & a & $(0 / 3)$ & $<1,3$ & & $(0 / 3)$ \\
\hline Sulfachloorpyridazine & $\mu \mathrm{g} / \mathrm{l}$ & $<1,2$ & a $(0 / 10)$ & $<1$ & a $(0 / 2)$ & $<1,3$ a & a $\quad(0 / 10)$ & $<1,0$ & a & $(0 / 3)$ & $<1,0$ & a ( & $(0 / 3)$ \\
\hline Sulfadoxine & $\mu \mathrm{g} / \mathrm{l}$ & $<1$ & a $(0 / 10)$ & $<1$ & a $(0 / 2)$ & $<1 \quad a$ & a $\quad(0 / 10)$ & $<1,0$ & a & $(0 / 3)$ & $<1,0$ & & $(0 / 3)$ \\
\hline Sulfamethoxazol & $\mu \mathrm{g} / \mathrm{l}$ & 0,1 & a $(1 / 10)$ & $<1$ & a $(0 / 2)$ & $<1,1$ a & a $\quad(0 / 10)$ & $<1,0$ & a & $(0 / 3)$ & $<1,0$ & a ( & $(0 / 3)$ \\
\hline Sulfisoxazol & $\mu \mathrm{g} / \mathrm{l}$ & $<1,1$ & a $(0 / 10)$ & $<1$ & a $(0 / 2)$ & $<1,1$ a & a $\quad(0 / 10)$ & $<1,0$ & a & $(0 / 3)$ & $<1,3$ & a ( & $(0 / 3)$ \\
\hline Sulfadimethoxine & $\mu \mathrm{g} / \mathrm{l}$ & $<1$ & a $(0 / 10)$ & $<1$ & a $(0 / 2)$ & $<1^{a}$ & a $\quad(0 / 10)$ & $<1,0$ & a & $(0 / 3)$ & $<1,0$ & a ( & $(0 / 3)$ \\
\hline Sulfaquinoxaline & $\mu \mathrm{g} / \mathrm{l}$ & $<1,2$ & a $(0 / 10)$ & $<1$ & a $(0 / 2)$ & $<1,1$ a & a $\quad(0 / 10)$ & $<1,0$ & a & $(0 / 3)$ & $<1,3$ & a ( & $(0 / 3)$ \\
\hline Sulfacetamide & $\mu \mathrm{g} / \mathrm{l}$ & $<1$ & a $(0 / 10)$ & $<1$ & a $(0 / 2)$ & $<1^{a}$ & a $\quad(0 / 10)$ & $<1,0$ & a & $(0 / 3)$ & $<1,0$ & & $(0 / 3)$ \\
\hline Sulfaphenazol & $\mu g / l$ & $<4,6$ & a $(0 / 10)$ & $<2$ & a $(0 / 2)$ & $<3,9$ a & a $\quad(0 / 10)$ & $<4,0$ & a & $(0 / 3)$ & $<4,0$ & a ( & $(0 / 3)$ \\
\hline Dapson & $\mu g / l$ & $<1$ & a $(0 / 10)$ & $<1$ & a $(0 / 2)$ & $<1^{a}$ & a $\quad(0 / 10)$ & $<1,0$ & a & $(0 / 3)$ & $<1,0$ & a ( & $(0 / 3)$ \\
\hline Marbofloxacine & $\mu g / l$ & 0,1 & a $(1 / 10)$ & $<1$ & b $(0 / 2)$ & $0,4^{a}$ & a $\quad(2 / 10)$ & $<1,0$ & b & $(0 / 3)$ & $<1,0$ & b ( & $(0 / 3)$ \\
\hline Norfloxacine & $\mu \mathrm{g} / \mathrm{l}$ & $<3,2$ & a $(0 / 10)$ & $<1,5$ & a $(0 / 2)$ & $<3,8$ a & a $\quad(0 / 10)$ & $<4,3$ & a & $(0 / 3)$ & $<1,3$ & a ( & $(0 / 3)$ \\
\hline Danofloxacine & $\mu g / l$ & $<2,4$ & a $(0 / 10)$ & $<1,5$ & a $(0 / 2)$ & $<2$ a & a $\quad(0 / 10)$ & $<1,0$ & a & $(0 / 3)$ & $<1,0$ & a ( & $(0 / 3)$ \\
\hline Sarafloxacine & $\mu \mathrm{g} / \mathrm{l}$ & $<5,9$ & a $(0 / 10)$ & $<5$ & a $(0 / 2)$ & $<6,3$ a & a $\quad(0 / 10)$ & $<6,3$ & a & $(0 / 3)$ & $<3,7$ & a ( & $(0 / 3)$ \\
\hline Difloxacine & $\mu \mathrm{g} / \mathrm{l}$ & $<1,9$ & a $(0 / 10)$ & $<1$ & a $(0 / 2)$ & $<1,9$ a & a $\quad(0 / 10)$ & $<1,0$ & a & $(0 / 3)$ & $<1,0$ & a ( & $(0 / 3)$ \\
\hline Oxolinezuur & $\mu \mathrm{g} / \mathrm{l}$ & $<1,5$ & a $(0 / 10)$ & $<1$ & a $(0 / 2)$ & $<1,5 \quad a$ & a $\quad(0 / 10)$ & $<1,0$ & a & $(0 / 3)$ & $<1,3$ & a ( & $(0 / 3)$ \\
\hline Nalidixinezuur & $\mu \mathrm{g} / \mathrm{l}$ & $<1,1$ & a $(0 / 10)$ & $<1$ & a $(0 / 2)$ & $<1,2^{a}$ & a $\quad(0 / 10)$ & $<1,0$ & a & $(0 / 3)$ & $<1,0$ & a ( & $(0 / 3)$ \\
\hline Levofloxacin/ofloxacin & $\mu g / l$ & $<3,9$ & a $(0 / 10)$ & $<5$ & a $(0 / 2)$ & $<3,7$ a & a $\quad(0 / 10)$ & $<2,3$ & a & $(0 / 3)$ & $<4,0$ & a ( & $(0 / 3)$ \\
\hline Trovafloxacin & $\mu g / l$ & $<1,5$ & a $(0 / 10)$ & $<1$ & a $(0 / 2)$ & $<1,1$ a & a $\quad(0 / 10)$ & $<1,7$ & a & $(0 / 3)$ & $<1,0$ & & $(0 / 3)$ \\
\hline
\end{tabular}




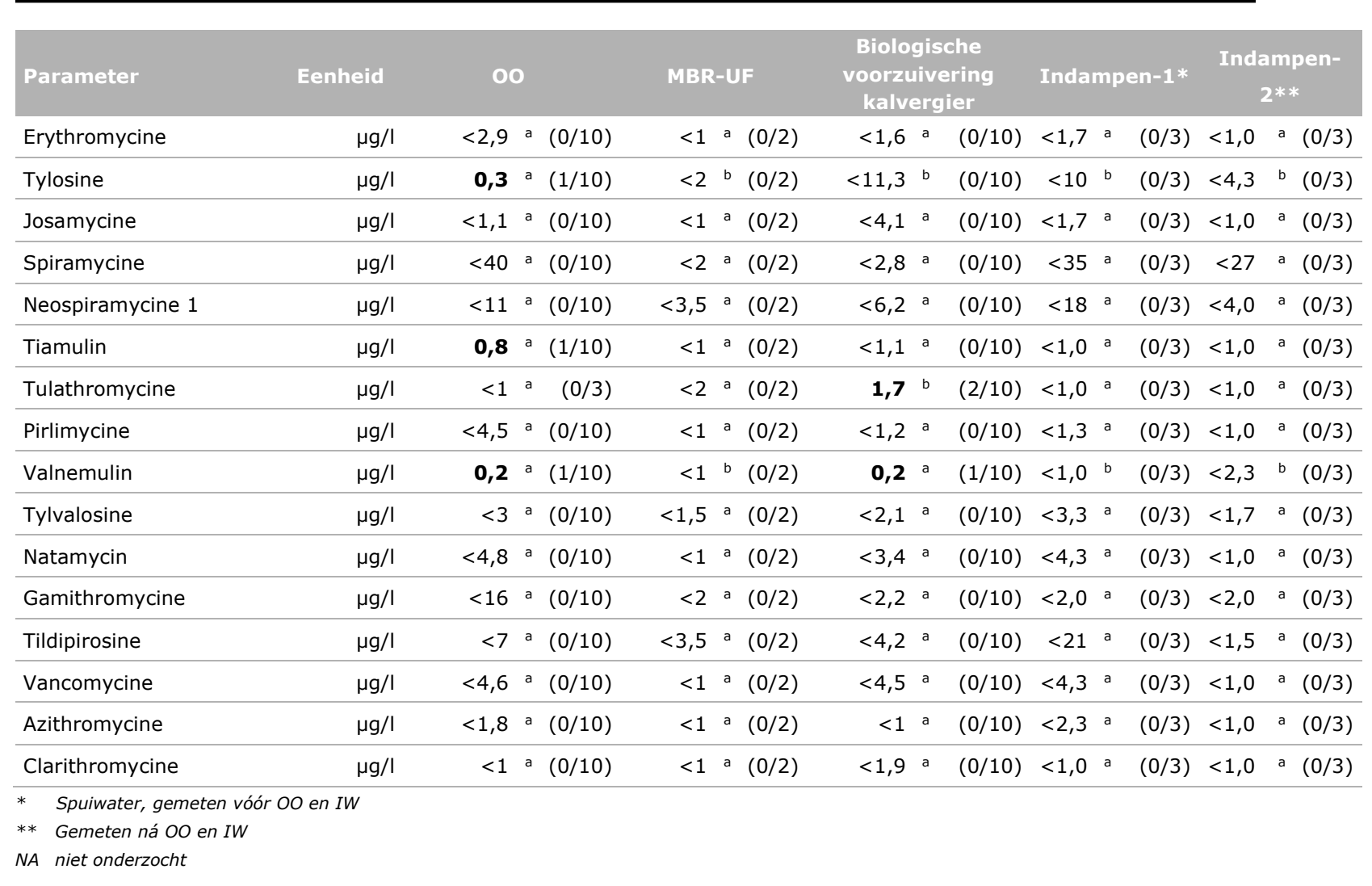



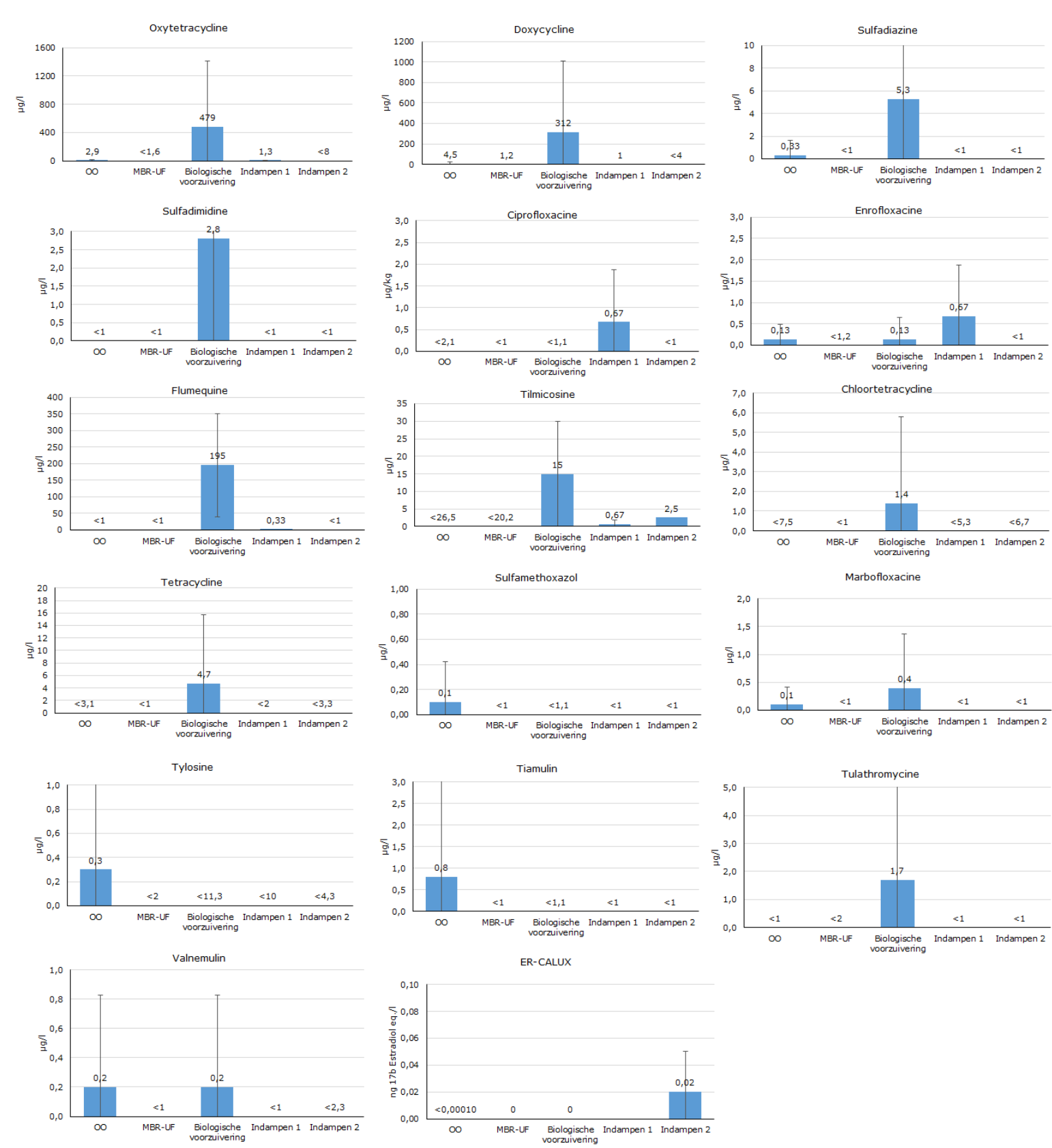

Figuur 3.7 Gemiddelde concentraties en variaties (plus en min 1 x standaarddeviatie) van antibiotica en hormoonstoffen in het effluent van vier typen MVI's. Alleen de parameters met minimaal één waarde boven de detectiegrens zijn in de figuur weergegeven. Indampen-1 is gemeten vóór, indampen-2 ná OO en IW.

Tabel 9 en Figuur 3.7 laten zien dat antibiotica in meetbare concentraties zijn aangetroffen in de effluenten van alle 4 typen MVI's, in één of meerdere monsters. In één monster van OO effluent werd een aantal antibiotica gedetecteerd, met relatief hoge meetwaarden voor oxytetracycline en doxycycline. In het effluent van MBR-UF werd alleen doxycycline in meetbare concentraties aangetroffen. De hoogste antibioticaconcentraties, van met name oxytetracycline, doxycycline en flumequine, zijn gemeten in het effluent van biologische voorzuivering bij kalvergierbewerking. Deze drie antibiotica werden in alle monsters teruggevonden. Van de 6 in het effluent van indampen-1 aangetroffen antibiotica, werd in indampen-2 (na behandeling met $\mathrm{OO}$ en IW) alleen tilmicosine in een meetbare concentratie teruggevonden. Oxytetracycline en doxycycline konden in het effluent van alle in dit onderzoek betrokken typen MVI's worden aangetoond. 
Zowel bij $\mathrm{OO}$ als bij MBR-UF en in mindere mate bij indampen zijn nog een aantal antibioticaresiduen in het effluent aanwezig. De conclusie kan zijn dat de effluenten van OO en MBR-UF wat de aanwezigheid van antibiotica betreft gelijkwaardig zijn. In tegenstelling tot het effluent van $0 O$ zijn in het effluent van MBR-UF wel hormoonstoffen aangetroffen.

Van de volgende antibiotica zijn risicogrenzen (PNEC's = Predicted No Effect Concentrations) gevonden voor water (Lahr et al, 2019):

\begin{tabular}{ll} 
Antibiotica & $\mu \mathrm{g} / \mathrm{l}$ \\
Oxytetracycline & 0,31 \\
\hline Doxycycline & 1,39 \\
\hline Sulfadiazine & 50 \\
\hline Sulfamethoxine & 0,12 \\
\hline Trimethoprim & 16 \\
\hline Tilmicosine & 0,16 \\
\hline Florfenicol & 4,81
\end{tabular}

In de effluenten van de vier MVI's zijn alleen voor oxytetracycline (OO, biologische voorzuivering en indampen-1) en doxycycline (OO en biologische voorzuivering) en tilmicosine (indampen-1 en indampen-2) hogere waarden gemeten dan de voor deze stoffen geldende PNEC's. Afhankelijk van de verdunning en de resulterende concentraties in het ontvangende water kan het lozen van deze effluenten schadelijke effecten voor het watermilieu opleveren.

Hormoonstoffen werden in meetbare concentraties aangetroffen in de effluenten van MBR-UF, biologische voorzuivering en indampen-2 (hoogste waarde!). 
Gemiddelde concentraties en standaardafwijking van micro-organismen in effluenten van de 4 typen MVI's. Tussen haakjes staat het aantal positieve waarnemingen aan het totale aantal waarnemingen. Voor berekening van de gemiddelde concentratie is voor monsters met waarnemingen onder de detectielimiet de waarde van de detectielimiet aangenomen. De eenheid is de decadische logaritme van de concentratie in $\mathrm{KVE} / \mathrm{g}(\log 10(\mathrm{KVE} / \mathrm{g}))$. Enkele voorbeelden: Een waarde van +2 staat gelijk aan $10^{2}$ of te wel $100 \mathrm{KVE} / \mathrm{g}$, een waarde van -2 staat gelijk aan $10^{-2}$ of te wel $0.01 \mathrm{KVE} / \mathrm{g}$. Betekenis van de letters in superscript: verschillende letters per regel betekent dat het verschil in concentratie t.o.v. OO effluent significant is $(p<0.05)$. Indien per locatie minder dan $30 \%$ van de waarnemingen boven de detectielimiet liggen, werd geen statistiek toegepast.

\begin{tabular}{|c|c|c|c|c|c|c|c|c|c|c|c|c|}
\hline \multirow[b]{2}{*}{ E. coli } & \multicolumn{3}{|l|}{ O० } & \multicolumn{3}{|l|}{ MBR-UF } & \multicolumn{2}{|c|}{$\begin{array}{l}\text { Biologische } \\
\text { voorzuivering } \\
\text { kalvergier }\end{array}$} & \multicolumn{4}{|c|}{ Indampen } \\
\hline & $-2,73$ & 0,20 & a $(4 / 9)$ & $-1,36$ & 0,27 & b $(3 / 3)$ & 2,22 & 0,20 & b $(7 / 8)$ & $<-2,66$ & & $(0 / 3)$ \\
\hline Enterokokken & $-2,78$ & 0,21 & a $(3 / 9)$ & $-0,84$ & 0,36 & b $(3 / 3)$ & 2,91 & 0,56 & b $(6 / 8)$ & $<-2,67$ & & $(0 / 3)$ \\
\hline Sporen van sulfietreducerende Clostridia & $-2,30$ & 0,26 & a $(7 / 9)$ & $-0,02$ & 0,15 & b $(3 / 3)$ & 3,24 & 0,13 & b $(8 / 8)$ & $-1,46$ & 0,80 a & a $\quad(3 / 3)$ \\
\hline Sporen van C. difficile & $-3,03$ & 0,06 & a $(2 / 9)$ & $-2,07$ & 0,33 & b $(3 / 3)$ & 0,84 & 0,26 & b $(7 / 8)$ & $<-2,67$ & & $(0 / 3)$ \\
\hline ESBL E. coli & $<-3,20$ & & $(0 / 6)$ & $<-2,48$ & & b $(0 / 3)$ & 0,20 & 0,15 & $(7 / 8)$ & $<-2,67$ & & $(0 / 3)$ \\
\hline Bacteriofagen & $-3,29$ & 0,43 & a $(4 / 4)$ & 0,08 & 0,12 & b $(3 / 3)$ & NA & & & NA & & \\
\hline Campylobacter & Afwezig & & $(0 / 4)$ & Afwezig & & $(0 / 1)$ & Aanwezig & & $(2 / 4)$ & Afwezig & & $(0 / 2)$ \\
\hline MRSA & Afwezig & & $(0 / 5)$ & Afwezig & & $(0 / 1)$ & Afwezig & & $(0 / 7)$ & Afwezig & & $(0 / 3)$ \\
\hline Hepatitis E virus & Afwezig & & $(0 / 4)$ & Afwezig & & $(0 / 2)$ & NA & & & NA & & \\
\hline
\end{tabular}
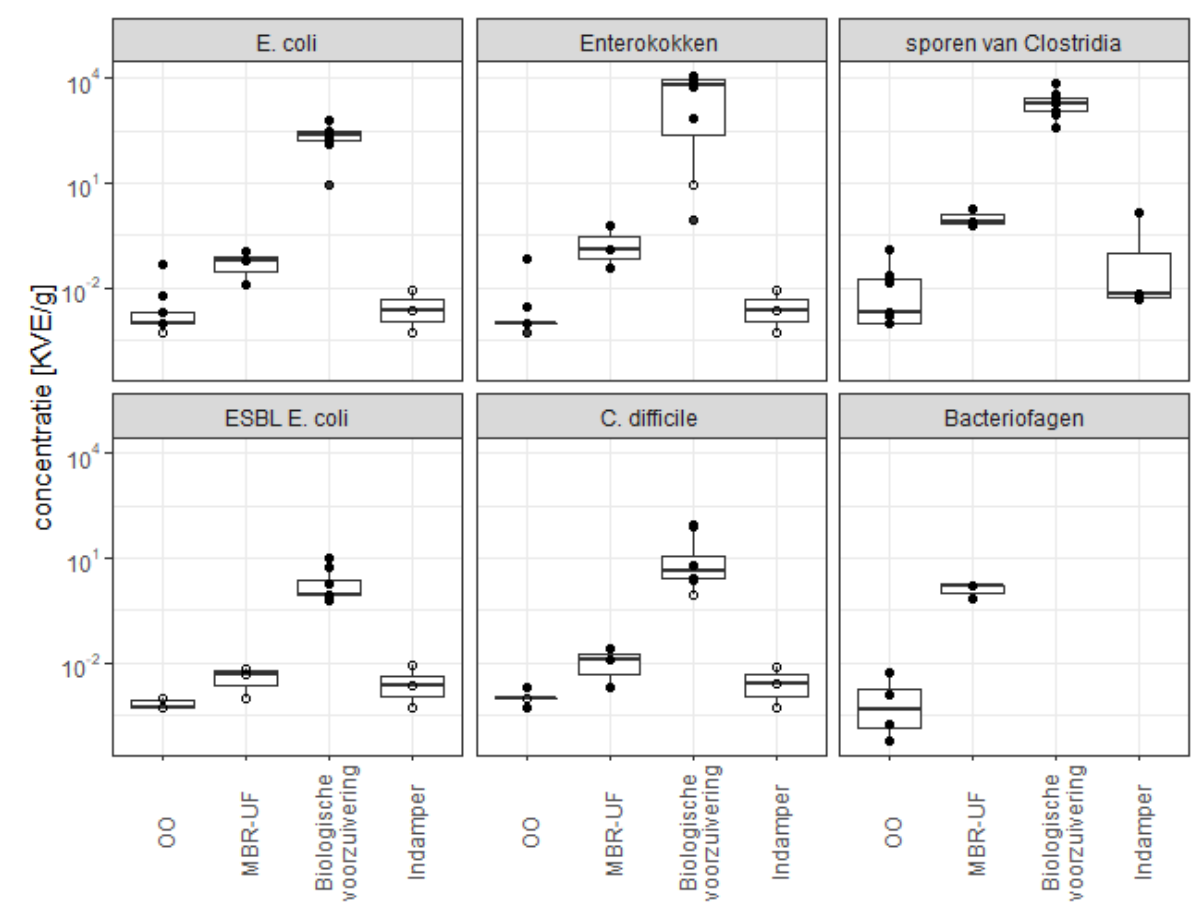

Figuur 3.8 Concentraties en hun variatie (mediaan als horizontale lijn, 25-75 percentiel als box, uitschieters als punten met een verticale verbinding naar de box) van micro-organismen in het effluent van vier typen MVI's. Waarden onder de detectielimiet zijn vervangen door de detectielimiet en met open symbolen aangeduid, waarden boven de detectielimiet zijn door gevulde symbolen aangeduid. 
Tabel 10 en Figuur 3.8 tonen dat de effluenten van 00 en indampen lagere concentraties van de indicatorbacteriën $E$. coli en enterokokken bevatten dan het effluent van MBR-UF en deze laatste weer aanzienlijk lagere concentraties bevatten dan biologische voorzuivering van kalvergier. Ook voor de indicator voor virussen, de somatische colifagen, en de indicator voor sporevormende bacteriën, Clostridia, zijn de concentraties in effluent OO significant lager dan in effluent MBR-UF. Wat betreft het effluent van de indamper, liggen alle metingen behalve die van sporen van sulfietreducerende Clostridia beneden de detectielimiet. De concentraties van sporen van Clostridia, die in het effluent van de indamper werden gemeten, waren significant hoger dan in effluent van OO. Clostridium difficile werd in de effluenten van OO, MBR-UF aangetoond.

In het effluent van biologische voorzuivering van kalvergier liggen de concentraties van alle microorganismen significant hoger dan in het effluent van de verwerkingstechnieken van varkensmest; zelfs 10.000 keer hoger dan in het effluent van OO. Resistente ESBL E. coli bacteriën werden uitsluitend in het effluent van biologische voorzuivering van kalvergier aangetoond.

De lage concentraties bacteriën en virussen in de effluenten van OO en MBR-UF komen overeen met de poriegrootte van de $O O(0,1-1,0 \mathrm{~nm})$ en de MBR-UF ( $\max 100 \mathrm{~nm})$ membranen. Intacte $O O$ membranen en MBR-UF membranen kunnen geen enterokokken, $E$. coli (al dan niet resistent) en MRSA laten passeren, omdat deze soorten groter zijn dan $200 \mathrm{~nm}$. De concentraties van indicatorbacteriën in het effluent van zowel OO als MBR-UF waren dan ook heel laag (ter vergelijking: effluent van rwzi bevat gemiddeld rond $3 * 10^{2} \mathrm{kve} / \mathrm{ml}$ E. coli (Schmitt et al. 2017), ongeveer 1000x hogere concentraties dan hier gemeten). Beschadiging van membranen of na-contaminatie kan een oorzaak zijn dat er toch micro-organismen in het effluent van 00 micro-organismen werden gevonden. In overeenstemming met de grotere poriegrootte werden wel significant hogere concentraties bacteriën in het effluent van MBR-UF gevonden dan in het effluent van OO. In tegenstelling tot de meeste bacteriën kunnen virussen wel intacte MBR-UF filters passeren (maar niet OO filters) omdat virussen meestal een grootte hebben van tussen de $20 \mathrm{~nm}$ tot enkele $100 \mathrm{~nm}$. Dit komt overeen met de duidelijk hogere concentraties somatische colifagen in het effluent van MBR-UF. Het effluent van indampen bestaat uit gecondenseerde waterdamp. Te verwachten zou zijn dat dit vrij van bacteriën en virussen is. Mogelijk was hier sprake van na-contaminatie. 


\subsection{Samenstelling van processtromen OO}

Tabel 11 Gemiddelde gehalten van algemene chemische parameters in processtromen van de OOinstallaties. Betekenis van de letters in superscript: verschillende letters per regel betekent dat het verschil in gehalte tussen processtromen significant is $(P<0.05)$. Tussen haakjes staat het aantal waarnemingen < detectiegrens en totale aantal waarnemingen.

\begin{tabular}{|c|c|c|c|c|c|c|c|c|c|c|c|c|c|}
\hline \multirow{2}{*}{$\begin{array}{l}\text { Parameter } \\
\text { BZV }\end{array}$} & \multirow{2}{*}{$\begin{array}{l}\text { Eenheid } \\
\text { mg/l }\end{array}$} & \multicolumn{3}{|c|}{ Ruwe mest } & \multicolumn{3}{|c|}{ Invoer Oo } & \multicolumn{3}{|c|}{ Concentraat $० ०$} & \multicolumn{3}{|c|}{ Effluent } \\
\hline & & 10490 & a & $(2 / 2)$ & 3147 & $\mathrm{~b}$ & $(7 / 7)$ & 6146 & $\mathrm{a}$ & $(7 / 7)$ & 0,71 & c & $(3 / 7)$ \\
\hline CZV & $\mathrm{mg} / \mathrm{l}$ & 76800 & a & $(2 / 2)$ & 8507 & $\mathrm{~b}$ & $(7 / 7)$ & 17596 & 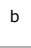 & $(7 / 7)$ & 1,1 & 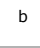 & $(1 / 7)$ \\
\hline Onopgeloste stoffen & $\mathrm{mg} / \mathrm{l}$ & NA & & $(0 / 0)$ & 1150 & ab & $(2 / 2)$ & 2400 & b & $(2 / 2)$ & $<5$ & ac & $(0 / 7)$ \\
\hline P-totaal & $\mathrm{mg} / \mathrm{kg}$ & 1556 & a & $(11 / 11)$ & 52 & $\mathrm{~b}$ & $(11 / 11)$ & 90 & 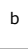 & $(11 / 11)$ & 2,4 & $\mathrm{~b}$ & $(11 / 11)$ \\
\hline $\mathrm{P}-\mathrm{PO}_{4}$ & $\mathrm{mg} / \mathrm{kg}$ & 238 & a & $(11 / 11)$ & 29 & bc & $(11 / 11)$ & 54 & b & $(11 / 11)$ & 0,81 & c & $(11 / 11)$ \\
\hline $\mathrm{N}$-totaal & $\mathrm{mg} / \mathrm{kg}$ & 5671 & a & $(11 / 11)$ & 3124 & $\mathrm{~b}$ & $(11 / 11)$ & 7605 & $d^{d}$ & $(11 / 11)$ & 7,2 & c & $(11 / 11)$ \\
\hline $\mathrm{N}-\mathrm{NH}_{4}$ & $\mathrm{mg} / \mathrm{kg}$ & 3207 & a & $(11 / 11)$ & 2618 & b & $(11 / 11)$ & 6332 & $d$ & $(11 / 11)$ & 16 & c & $(11 / 11)$ \\
\hline $\mathrm{NO}_{2}-\mathrm{N}+\mathrm{NO}_{3}-\mathrm{N}$ & $\mathrm{mg} / \mathrm{kg}$ & 0,19 & a & $(11 / 11)$ & 0,37 & a & $(11 / 11)$ & 1,6 & & $(11 / 11)$ & 0,1 & a & $(11 / 11)$ \\
\hline $\mathrm{pH}$ & - & 7,7 & ab & $(11 / 11)$ & 7,8 & ab & $(11 / 11)$ & 8 & & $(11 / 11)$ & 7,2 & b & $(11 / 11)$ \\
\hline EC & $\mathrm{mS} / \mathrm{cm}$ & 27 & a & $(11 / 11)$ & 29 & $\mathrm{ab}$ & $(11 / 11)$ & 62 & & $(11 / 11)$ & 0,21 & d & $(11 / 11)$ \\
\hline $\mathrm{Cl}-$ & $\mathrm{mg} / \mathrm{kg}$ & 1816 & a & $(11 / 11)$ & 1618 & a & $(11 / 11)$ & 3769 & & $(11 / 11)$ & 14 & c & $(11 / 11)$ \\
\hline $\mathrm{s}$ & $\mathrm{mg} / \mathrm{kg}$ & 856 & a & $(11 / 11)$ & 1745 & $\mathrm{~b}$ & $(11 / 11)$ & 4816 & & $(11 / 11)$ & 6,4 & d & $(11 / 11)$ \\
\hline K & $\mathrm{mg} / \mathrm{kg}$ & 4245 & a & $(11 / 11)$ & 3300 & a & $(11 / 11)$ & 8091 & 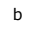 & $(11 / 11)$ & 0 & b & $(11 / 11)$ \\
\hline
\end{tabular}

NA niet onderzocht 

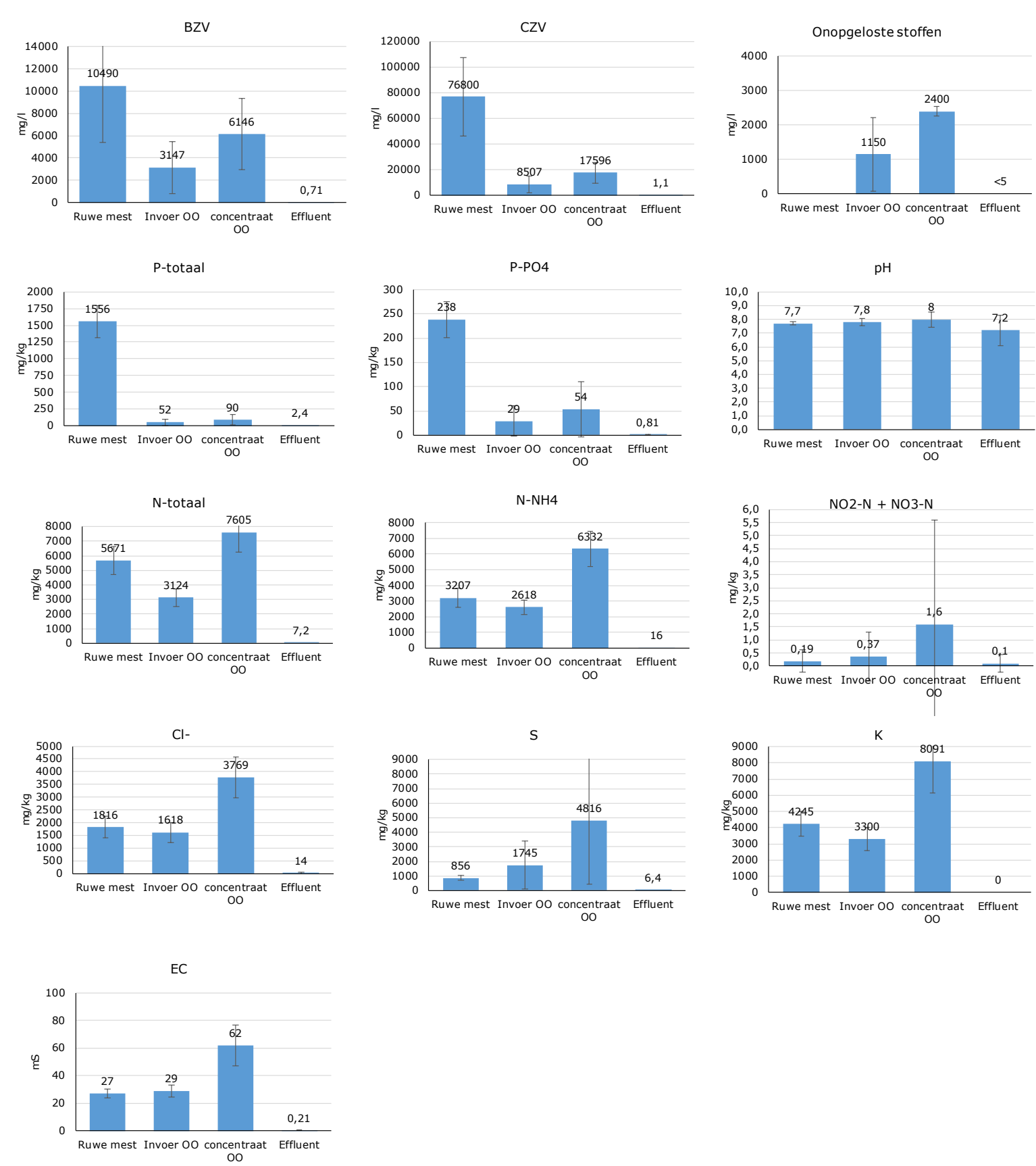

Figuur 3.9 Gemiddelde concentraties en variaties (plus en min 1 x standaarddeviatie) van algemene chemische parameters in processtromen van de OO-installaties.

Tabel 11 en Figuur 3.9 tonen dat scheiding van de ruwe mest door middel van een zeefbandpers gevolgd door dissolved air flotation als voorzuivering voor omgekeerde osmose zeer effectief is voor het verwijderen van BZV, CZV, P-totaal en $\mathrm{P}_{-} \mathrm{PO}_{4}$; de gehalten in de invoer $\mathrm{OO}$ zijn resp. 58\%, 92\%, $96 \%$ en $87 \%$ lager dan in de ruwe mest. Het effect op de opgeloste en gedeeltelijk opgeloste

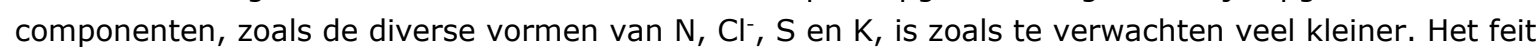
dat de invoer $\mathrm{OO}$ een hoger gehalte aan $\mathrm{S}$ laat zien dan de ruwe mest kan worden verklaard door het gebruik van zwavelzuur als hulpstof (coagulant) bij flotatie.

De gehalten in het concentraat OO zijn globaal een factor 2 hoger dan in de invoer OO. Dit is wat bij vleesvarkensmest als ingangsmateriaal verwacht mag worden en in overeenstemming met de resultaten van Hoeksma et al (2011). Als het ingangsmateriaal meer water bevat, dus dunner is zoals zeugenmest, dan is er sprake van een hogere concentratiefactor en zijn dus hogere concentraties van algemene chemische parameters mogelijk (Hoeksma en de Buisonjé, 2015).

Omgekeerde osmose gevolgd door ionenwisseling resulteert in een helder effluent waarin een aantal opgeloste stoffen in lage concentraties wordt aangetroffen. Het effluent is nagenoeg vrij van organische stof, maar bevat nog lage gehalten aan N-totaal en P-totaal. Daarnaast bevat het effluent, 
ondanks een nageschakelde ionenwisselaar, ammonium in een concentratie die hoger is dan de waterkwaliteitsnorm voor oppervlaktewater.

Tabel 12 Gemiddelde concentraties van zware metalen in processtromen van de OO-installaties.

Betekenis van de letters in superscript: verschillende letters per regel betekent dat het verschil in concentratie tussen processtromen significant is $(P<0,05)$. Tussen haakjes staat het aantal waarnemingen > detectiegrens en het totale aantal waarnemingen.

\begin{tabular}{|c|c|c|c|c|c|c|c|c|c|c|c|}
\hline \multirow{2}{*}{$\begin{array}{l}\text { Parameter } \\
\mathrm{Cd}\end{array}$} & \multirow{2}{*}{$\begin{array}{l}\text { Eenheid } \\
\mathrm{mg} / \mathrm{kg}\end{array}$} & \multicolumn{2}{|c|}{ Ruwe mest } & \multicolumn{3}{|c|}{ Invoer oo } & \multicolumn{2}{|c|}{ Concentraat 00} & \multicolumn{3}{|c|}{ Effluent } \\
\hline & & 0,05 & a $(11 / 11)$ & $<0,027$ & a & $(0 / 11)$ & $<0,027$ & $(0 / 11)$ & $<0,027$ & a & $(0 / 11)$ \\
\hline $\mathrm{Hg}$ & $\mathrm{mg} / \mathrm{kg}$ & $<0,01$ & a $\quad(0 / 11)$ & $<0,012$ & a & $(0 / 11)$ & $<0,012$ & a $\quad(0 / 11)$ & $<0,012$ & a & $(0 / 11)$ \\
\hline $\mathrm{Pb}$ & $\mathrm{mg} / \mathrm{kg}$ & 0,19 & a $(11 / 11)$ & $<0,013$ & b & $(0 / 11)$ & $<0,013$ & $(0 / 11)$ & $<0,013$ & b & $(0 / 11)$ \\
\hline As & $\mathrm{mg} / \mathrm{kg}$ & $<0,13$ & a $\quad(0 / 11)$ & $<0,11$ & a & $(0 / 11)$ & $<0,11$ & a $\quad(0 / 11)$ & $<0,11$ & a & $(0 / 11)$ \\
\hline $\mathrm{Cr}$ & $\mathrm{mg} / \mathrm{kg}$ & 0,93 & a $(11 / 11)$ & 0,01 & b & $(1 / 11)$ & 0,05 & b $\quad(6 / 11)$ & $<0,074$ & a & $(0 / 11)$ \\
\hline $\mathrm{Ni}$ & $\mathrm{mg} / \mathrm{kg}$ & 1 & a $(11 / 11)$ & 0,27 & a & $(11 / 11)$ & 0,46 & a $(10 / 11)$ & 0,01 & a & $(1 / 11)$ \\
\hline $\mathrm{Cu}$ & $\mathrm{mg} / \mathrm{kg}$ & 26 & a $(11 / 11)$ & $<0,57$ & a & $(0 / 11)$ & 0,32 & a $\quad(5 / 11)$ & $<0,57$ & $\mathrm{~b}$ & $(0 / 11)$ \\
\hline $\mathrm{Zn}$ & $\mathrm{mg} / \mathrm{kg}$ & 95 & a $(11 / 11)$ & 0,37 & $\mathrm{~b}$ & $(3 / 11)$ & 0,81 & b $\quad(5 / 11)$ & $<1,1$ & a & $(0 / 11)$ \\
\hline $\mathrm{Ba}$ & $\mathrm{mg} / \mathrm{kg}$ & 5 & a $(11 / 11)$ & 0,03 & b & $(2 / 11)$ & 0,09 & $(4 / 11)$ & $<0,16$ & a & $(0 / 11)$ \\
\hline v & $\mathrm{mg} / \mathrm{kg}$ & 0,35 & $(5 / 9)$ & $<0,28$ & a & $(0 / 9)$ & $<0,28$ & $(0 / 9)$ & $<0,28$ & a & $(0 / 9)$ \\
\hline U & $\mathrm{mg} / \mathrm{kg}$ & 0,04 & $(3 / 9)$ & $<0,062$ & a & $(0 / 9)$ & $<0,062$ & $(0 / 9)$ & $<0,062$ & a & $(0 / 9)$ \\
\hline Co & $\mathrm{mg} / \mathrm{kg}$ & 0,12 & $(8 / 8)$ & NA & & $(0 / 0)$ & NA & $(0 / 0)$ & $<0,016$ & a & $(0 / 8)$ \\
\hline $\mathrm{Se}$ & $\mathrm{mg} / \mathrm{kg}$ & 0,26 & $(8 / 8)$ & NA & & $(0 / 0)$ & NA & $(0 / 0)$ & $<0,032$ & a & $(0 / 8)$ \\
\hline
\end{tabular}



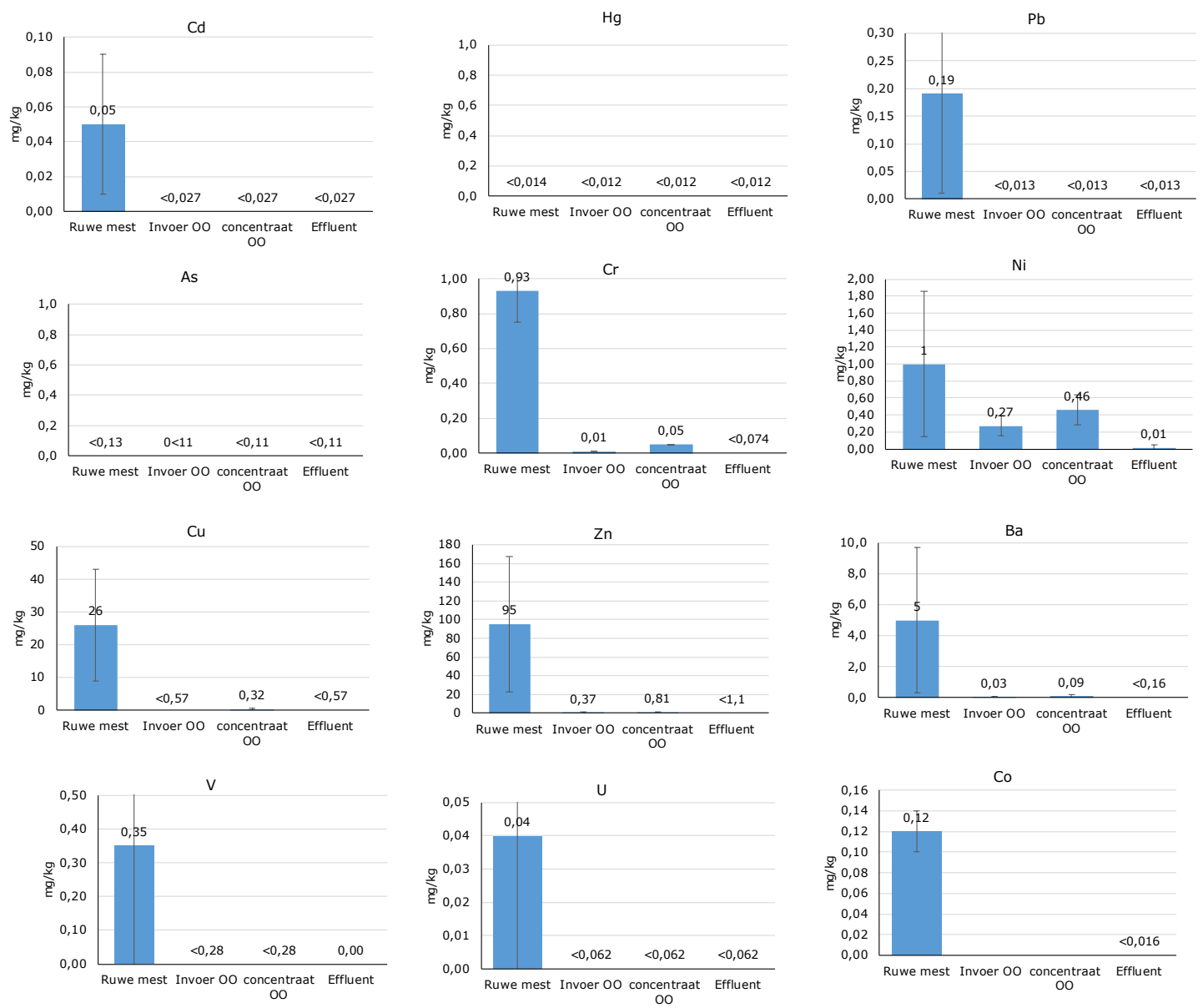

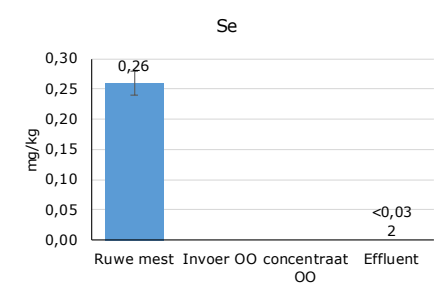

Figuur 3.10 Gemiddelde concentraties en variaties (plus en min 1 x standaarddeviatie) van zware metalen in processtromen van de OO-installaties.

$\mathrm{Na}$ mechanische scheiding door middel van een zeefbandpers en vervolgens een behandeling middels dissolved air flotation (DAF) vindt 90-100 \% reductie plaats van de zware metalen, wat erin resulteert dat in de invoer 00 nog slechts enkele metalen (chroom, nikkel, zink en barium) in meetbare concentraties aanwezig zijn. Dit duidt erop dat zware metalen hechten aan vaste stof en na scheiding vrijwel volledig in de dikke fractie achterblijven.

$\mathrm{Na}$ omgekeerde osmose worden in het concentraat $\mathrm{OO}$ dezelfde 4 metalen aangetroffen, in hogere concentraties dan in de invoer $\mathrm{OO}$ zoals te verwachten was. Het concentraat $\mathrm{OO}$ bevat tevens een gering gehalte aan koper; in ongeveer de helft van de monsters werd koper aangetoond.

Wegens de hoge detectiegrenzen van de toegepaste analysemethode kan de zuiveringsefficiëntie van OO voor zware metalen onvoldoende in beeld worden gebracht. Toetsing van de meetwaarden van zware metalen in het effluent aan de normen voor oppervlaktewater is gebaseerd op de huidige metingen niet mogelijk. 
Tabel 13 Gemiddelde concentraties van hormoonstoffen en antibiotica in processtromen van de OOinstallaties. Waarden boven de detectiegrens zijn vetgedrukt. Betekenis van de letters in superscript: verschillende letters per regel betekent dat het verschil in concentratie tussen processtromen significant is $(P<0,05)$. Tussen haakjes staat het aantal waarnemingen $>$ detectiegrens en het totale aantal waarnemingen.

\begin{tabular}{|c|c|c|c|c|c|c|c|c|c|c|c|c|}
\hline \multirow{2}{*}{$\begin{array}{l}\text { Parameter } \\
\text { Hormoonstoffen }\end{array}$} & \multirow[t]{2}{*}{ Eenheid } & \multicolumn{3}{|c|}{ Ruwe mest } & \multicolumn{3}{|c|}{ Invoer 00} & \multicolumn{3}{|c|}{ Concentraat 00} & \multicolumn{2}{|c|}{ Effluent } \\
\hline & & & & & & & & & & & & \\
\hline ER-CALUX & $\mathrm{ng} 17 \mathrm{BEQ} / \mathrm{g}$ & 16 & $\mathrm{a}$ & $(2 / 2)$ & 0,66 & $\mathrm{~b}$ & $(2 / 2)$ & 1,2 & $\mathrm{~b}$ & $(2 / 2)$ & $<0,00010$ & b $\quad(0 / 2)$ \\
\hline \multicolumn{13}{|l|}{ Antibiotica } \\
\hline Oxytetracycline & $\mu \mathrm{g} / \mathrm{kg}$ & 217 & a & $(12 / 12)$ & 67 & $\mathrm{~b}$ & $(9 / 15)$ & 41 & $\mathrm{~b}$ & $(10 / 15)$ & 2,9 & b $(1 / 15)$ \\
\hline Doxycycline & $\mu \mathrm{g} / \mathrm{kg}$ & 345 & a & $(11 / 12)$ & 131 & b & $(10 / 15)$ & 57 & $\mathrm{~b}$ & $(11 / 15)$ & 4,5 & b $\quad(1 / 15)$ \\
\hline Sulfadiazine & $\mu g / k g$ & 5,8 & a & $(6 / 12)$ & 3,3 & ab & $(11 / 15)$ & 7,2 & $\mathrm{a}$ & $(13 / 15)$ & 0,33 & b $\quad(1 / 15)$ \\
\hline Sulfadimidine & $\mu \mathrm{g} / \mathrm{kg}$ & $<1$ & a & $(0 / 12)$ & $<1$ & a & $(0 / 15)$ & $<1,1$ & $\mathrm{a}$ & $(0 / 15)$ & $<1$ & a $(0 / 15)$ \\
\hline Trimethoprim & $\mu \mathrm{g} / \mathrm{kg}$ & $<1,5$ & $\mathrm{a}$ & $(0 / 12)$ & $<1,4$ & $\mathrm{a}$ & $(0 / 15)$ & $<1,7$ & $\mathrm{a}$ & $(0 / 15)$ & $<1,1$ & a $(0 / 15)$ \\
\hline Ciprofloxacine & $\mu \mathrm{g} / \mathrm{kg}$ & $<5,7$ & $\mathrm{a}$ & $(0 / 12)$ & $<3,7$ & $\mathrm{a}$ & $(0 / 15)$ & $<4,3$ & $\mathrm{a}$ & $(0 / 15)$ & $<21$ & a $(0 / 15)$ \\
\hline Enrofloxacine & $\mu \mathrm{g} / \mathrm{kg}$ & $<8,4$ & a & $(0 / 12)$ & $<5,9$ & a & $(0 / 15)$ & $<6,1$ & a & $(0 / 15)$ & 0,13 & a $(2 / 15)$ \\
\hline Flumequine & $\mu \mathrm{g} / \mathrm{kg}$ & 6,3 & a & $(3 / 12)$ & 0,13 & $\mathrm{a}$ & $(1 / 15)$ & 0,13 & a & $(1 / 15)$ & $<1$ & b $(0 / 15)$ \\
\hline Lincomycine & $\mu g / k g$ & $<1,8$ & $\mathrm{a}$ & $(0 / 12)$ & 0,13 & $\mathrm{~b}$ & $(1 / 15)$ & 0,13 & $\mathrm{a}$ & $(1 / 15)$ & $<1,3$ & a $(0 / 15)$ \\
\hline Tilmicosine & $\mu \mathrm{g} / \mathrm{kg}$ & 1,3 & a & $(4 / 12)$ & 0,4 & a & $(2 / 15)$ & 0,6 & $\mathrm{a}$ & $(3 / 15)$ & $<26$ & b $\quad(0 / 15)$ \\
\hline Florfenicol & $\mu \mathrm{g} / \mathrm{kg}$ & $<1,7$ & & $(0 / 12)$ & $<1,4$ & & $(0 / 15)$ & $<1,9$ & & $(0 / 15)$ & $<1$ & $(0 / 15)$ \\
\hline Chloortetracycline & $\mu \mathrm{g} / \mathrm{kg}$ & 3,7 & a & $(1 / 6)$ & $<10$ & a & $(0 / 10)$ & $<15$ & a & $(0 / 10)$ & $<7,5$ & a $(0 / 10)$ \\
\hline Tetracycline & $\mu g / k g$ & 1 & $\mathrm{a}$ & $(1 / 7)$ & $<5,4$ & a & $(0 / 10)$ & $<9,1$ & a & $(0 / 10)$ & $<3,1$ & a $(0 / 10)$ \\
\hline Minocycline & $\mu \mathrm{g} / \mathrm{kg}$ & $<30$ & a & $(0 / 6)$ & $<17$ & a & $(0 / 10)$ & $<26$ & $\mathrm{a}$ & $(0 / 10)$ & $<12$ & a $(0 / 10)$ \\
\hline Methacycline & $\mu \mathrm{g} / \mathrm{kg}$ & $<22$ & a & $(0 / 7)$ & $<11,8$ & $\mathrm{a}$ & $(0 / 10)$ & $<19$ & $\mathrm{a}$ & $(0 / 10)$ & $<5,9$ & a $(0 / 10)$ \\
\hline Sulfathiazol & $\mu \mathrm{g} / \mathrm{kg}$ & $<4$ & a & $(0 / 7)$ & $<3,1$ & a & $(0 / 10)$ & $<4$ & a & $(0 / 10)$ & $<1,4$ & a $(0 / 10)$ \\
\hline Sulfapyridine & $\mu \mathrm{g} / \mathrm{kg}$ & $<1,4$ & a & $(0 / 7)$ & $<1,7$ & a & $(0 / 10)$ & $<1,6$ & $\mathrm{a}$ & $(0 / 10)$ & $<1,2$ & a $(0 / 10)$ \\
\hline Sulfamerazine & $\mu \mathrm{g} / \mathrm{kg}$ & $<1,1$ & a & $(0 / 7)$ & $<1$ & $\mathrm{a}$ & $(0 / 10)$ & $<1,4$ & $\mathrm{a}$ & $(0 / 10)$ & $<1$ & a $(0 / 10)$ \\
\hline Sulfamoxol & $\mu \mathrm{g} / \mathrm{kg}$ & $<1,4$ & a & $(0 / 7)$ & $<1,5$ & a & $(0 / 10)$ & $<1,4$ & $\mathrm{a}$ & $(0 / 10)$ & $<1,2$ & a $(0 / 10)$ \\
\hline Sulfamethizol & $\mu \mathrm{g} / \mathrm{kg}$ & $<2$ & a & $(0 / 7)$ & $<1,4$ & a & $(0 / 10)$ & $<2,3$ & a & $(0 / 10)$ & $<1$ & a $(0 / 10)$ \\
\hline Sulfamethoxypyridazine & $\mu \mathrm{g} / \mathrm{kg}$ & $<1$ & a & $(0 / 7)$ & $<1$ & a & $(0 / 10)$ & $<1,2$ & $\mathrm{a}$ & $(0 / 10)$ & $<1$ & a $(0 / 10)$ \\
\hline Sulfamonomethoxine & $\mu \mathrm{g} / \mathrm{kg}$ & $<2,3$ & a & $(0 / 7)$ & $<1,4$ & a & $(0 / 10)$ & $<2,1$ & $\mathrm{a}$ & $(0 / 10)$ & $<1,1$ & a $(0 / 10)$ \\
\hline Sulfachloorpyridazine & $\mu \mathrm{g} / \mathrm{kg}$ & $<2,7$ & a & $(0 / 7)$ & $<2,4$ & a & $(0 / 10)$ & $<3,5$ & a & $(0 / 10)$ & $<1,2$ & a $(0 / 10)$ \\
\hline Sulfadoxine & $\mu \mathrm{g} / \mathrm{kg}$ & $<1,1$ & a & $(0 / 7)$ & $<1$ & a & $(0 / 10)$ & $<1,1$ & $\mathrm{a}$ & $(0 / 10)$ & $<1$ & a $(0 / 10)$ \\
\hline Sulfamethoxazol & $\mu \mathrm{g} / \mathrm{kg}$ & $<1,4$ & & $(0 / 7)$ & 0,8 & ab & $(1 / 10)$ & 2,3 & $\mathrm{~b}$ & $(3 / 10)$ & 0,1 & a $(1 / 10)$ \\
\hline Sulfisoxazol & $\mu g / k g$ & $<2,4$ & & $(0 / 7)$ & $<1,6$ & & $(0 / 10)$ & $<2$ & $\mathrm{a}$ & $(0 / 10)$ & $<1,1$ & a $(0 / 10)$ \\
\hline Sulfadimetho & $\mu \mathrm{g} / \mathrm{kg}$ & $<1,3$ & a & $(0 / 7)$ & $<1$ & $\mathrm{a}$ & $(0 / 10)$ & $<1,4$ & $\mathrm{a}$ & $(0 / 10)$ & $<1$ & a $(0 / 10)$ \\
\hline Sulfaquinoxaline & $\mu \mathrm{g} / \mathrm{kg}$ & $<3,6$ & a & $(0 / 7)$ & $<2,1$ & a & $(0 / 10)$ & $<3,7$ & $\mathrm{a}$ & $(0 / 10)$ & $<1,2$ & a $(0 / 10)$ \\
\hline Sulfacetamide & $\mu \mathrm{g} / \mathrm{kg}$ & $<1,1$ & a & $(0 / 7)$ & $<1,4$ & $\mathrm{a}$ & $(0 / 10)$ & $<1,9$ & $\mathrm{a}$ & $(0 / 10)$ & $<1$ & a $(0 / 10)$ \\
\hline Sulfaphenazol & $\mu \mathrm{g} / \mathrm{kg}$ & $<12$ & a & $(0 / 7)$ & $<8,3$ & a & $(0 / 10)$ & $<13$ & a & $(0 / 10)$ & $<4,6$ & a $(0 / 10)$ \\
\hline Dapson & $\mu \mathrm{g} / \mathrm{kg}$ & $<1,1$ & a & $(0 / 7)$ & $<1$ & a & $(0 / 10)$ & $<1,6$ & a & $(0 / 10)$ & $<1$ & a $(0 / 10)$ \\
\hline Marbofloxacine & $\mu \mathrm{g} / \mathrm{kg}$ & $<7,8$ & a & $(0 / 7)$ & $<4,4$ & a & $(0 / 10)$ & $<4,7$ & a & $(0 / 10)$ & 0,1 & a $(1 / 10)$ \\
\hline Norfloxacine & $\mu \mathrm{g} / \mathrm{kg}$ & $<21$ & $\mathrm{a}$ & $(0 / 7)$ & $<13$ & $\mathrm{a}$ & $(0 / 10)$ & $<16$ & a & $(0 / 10)$ & $<3,2$ & a $(0 / 10)$ \\
\hline Danofloxacine & $\mu g / k g$ & $<16$ & a & $(0 / 7)$ & $<11$ & a & $(0 / 10)$ & $<12$ & a & $(0 / 10)$ & $<2,4$ & a $(0 / 10)$ \\
\hline Sarafloxacine & $\mu \mathrm{g} / \mathrm{kg}$ & $<20$ & a & $(0 / 7)$ & $<9,9$ & a & $(0 / 10)$ & $<16$ & a & $(0 / 10)$ & $<5,9$ & a $(0 / 10)$ \\
\hline Difloxacine & $\mu \mathrm{g} / \mathrm{kg}$ & $<11$ & $\mathrm{a}$ & $(0 / 7)$ & $<7,3$ & $\mathrm{a}$ & $(0 / 10)$ & $<12$ & a & $(0 / 10)$ & $<1,9$ & a $(0 / 10)$ \\
\hline Oxolinezuur & $\mu \mathrm{g} / \mathrm{kg}$ & $<7$ & a & $(0 / 7)$ & $<3,7$ & a & $(0 / 10)$ & $<5,1$ & a & $(0 / 10)$ & $<1,5$ & a $(0 / 10)$ \\
\hline Nalidixinezuur & $\mu \mathrm{g} / \mathrm{kg}$ & $<8$ & $\mathrm{a}$ & $(0 / 7)$ & $<4,9$ & $\mathrm{a}$ & $(0 / 10)$ & $<5,7$ & a & $(0 / 10)$ & $<1,1$ & a $(0 / 10)$ \\
\hline Levofloxacin/ofloxacin & $\mu g / k g$ & $<8$ & a & $(0 / 7)$ & $<5,3$ & a & $(0 / 10)$ & $<6,3$ & a & $(0 / 10)$ & $<3,9$ & a $(0 / 10)$ \\
\hline Trovafloxacin & $\mu \mathrm{g} / \mathrm{kg}$ & $<4,8$ & a & $(0 / 7)$ & $<2,8$ & a & $(0 / 10)$ & $<3,6$ & a & $(0 / 10)$ & $<1,5$ & a $(0 / 10)$ \\
\hline Erythromycine & $\mu \mathrm{g} / \mathrm{kg}$ & $<24$ & $\mathrm{a}$ & $(0 / 7)$ & $<17$ & $\mathrm{a}$ & $(0 / 10)$ & $<28$ & a & $(0 / 10)$ & $<2,9$ & a $(0 / 10)$ \\
\hline
\end{tabular}




\begin{tabular}{|c|c|c|c|c|c|c|c|c|c|c|c|c|}
\hline \multirow{2}{*}{$\begin{array}{l}\text { Parameter } \\
\text { Tylosine }\end{array}$} & \multirow{2}{*}{$\begin{array}{l}\text { Eenheid } \\
\qquad \mu \mathrm{g} / \mathrm{kg}\end{array}$} & \multicolumn{3}{|c|}{ Ruwe mest } & \multicolumn{3}{|c|}{ Invoer oo } & \multicolumn{3}{|c|}{ Concentraat 00} & \multicolumn{2}{|c|}{ Effluent } \\
\hline & & 4,7 & a & $(6 / 7)$ & 1,7 & ab & $(1 / 10)$ & 0,7 & $\mathrm{~b}$ & $(2 / 10)$ & 0,3 & b $(1 / 10)$ \\
\hline Josamycine & $\mu \mathrm{g} / \mathrm{kg}$ & $<2,4$ & a & $(0 / 7)$ & $<5,5$ & a & $(0 / 10)$ & $<7,1$ & a & $(0 / 10)$ & $<1,1$ & a $(0 / 10)$ \\
\hline Spiramycine & $\mu \mathrm{g} / \mathrm{kg}$ & $<9,3$ & a & $(0 / 7)$ & $<7,1$ & a & $(0 / 10)$ & $<11$ & a & $(0 / 10)$ & $<40$ & a $(0 / 10)$ \\
\hline Neospiramycine 1 & $\mu \mathrm{g} / \mathrm{kg}$ & $<8$ & a & $(0 / 7)$ & $<5,8$ & a & $(0 / 10)$ & $<7,6$ & a & $(0 / 10)$ & $<11$ & a $(0 / 10)$ \\
\hline Tiamulin & $\mu \mathrm{g} / \mathrm{kg}$ & 12 & a & $(2 / 7)$ & 19 & a & $(3 / 10)$ & 1,1 & a & $(3 / 10)$ & 0,8 & a $(1 / 10)$ \\
\hline Tulathromycine & $\mu \mathrm{g} / \mathrm{kg}$ & $<11$ & a & $(0 / 7)$ & $<4,1$ & a & $(0 / 10)$ & $<4$ & a & $(0 / 10)$ & $<1$ & a $(0 / 10)$ \\
\hline Pirlimycine & $\mu \mathrm{g} / \mathrm{kg}$ & $<2$ & a & $(0 / 7)$ & $<1,9$ & a & $(0 / 10)$ & $<2,7$ & a & $(0 / 10)$ & $<4,5$ & a $(0 / 10)$ \\
\hline Valnemulin & $\mu \mathrm{g} / \mathrm{kg}$ & $<2,4$ & a & $(0 / 7)$ & $<2$ & a & $(0 / 10)$ & $<2,1$ & a & $(0 / 10)$ & 0,2 & a $(1 / 10)$ \\
\hline Tylvalosine & $\mu \mathrm{g} / \mathrm{kg}$ & $<2,7$ & a & $(0 / 7)$ & $<1,5$ & a & $(0 / 10)$ & $<3,6$ & a & $(0 / 10)$ & $<3$ & a $(0 / 10)$ \\
\hline Natamycin & $\mu \mathrm{g} / \mathrm{kg}$ & $<12$ & a & $(0 / 7)$ & $<8,8$ & a & $(0 / 10)$ & $<12$ & a & $(0 / 10)$ & $<4,8$ & a $(0 / 10)$ \\
\hline Gamithromycine & $\mu \mathrm{g} / \mathrm{kg}$ & $<2,1$ & a & $(0 / 7)$ & $<2,1$ & a & $(0 / 10)$ & $<2,8$ & a & $(0 / 10)$ & $<16$ & a $(0 / 10)$ \\
\hline Tildipirosine & $\mu \mathrm{g} / \mathrm{kg}$ & $<7,3$ & a & $(0 / 7)$ & $<5,3$ & a & $(0 / 10)$ & $<1,8$ & a & $(0 / 10)$ & $<7$ & a $(0 / 10)$ \\
\hline Vancomycine & $\mu \mathrm{g} / \mathrm{kg}$ & $<14$ & a & $(0 / 7)$ & $<14$ & a & $(0 / 10)$ & $<26$ & a & $(0 / 10)$ & $<4,6$ & a $(0 / 10)$ \\
\hline Azithromycine & $\mu \mathrm{g} / \mathrm{kg}$ & $<2,6$ & a & $(0 / 7)$ & $<2,1$ & a & $(0 / 10)$ & $<2,7$ & a & $(0 / 10)$ & $<1,8$ & a $(0 / 10)$ \\
\hline Clarithromycine & $\mu \mathrm{g} / \mathrm{kg}$ & $<2,6$ & a & $(0 / 7)$ & $<2,7$ & a & $(0 / 10)$ & $<3,6$ & a & $(0 / 10)$ & $<1$ & a $(0 / 10)$ \\
\hline
\end{tabular}



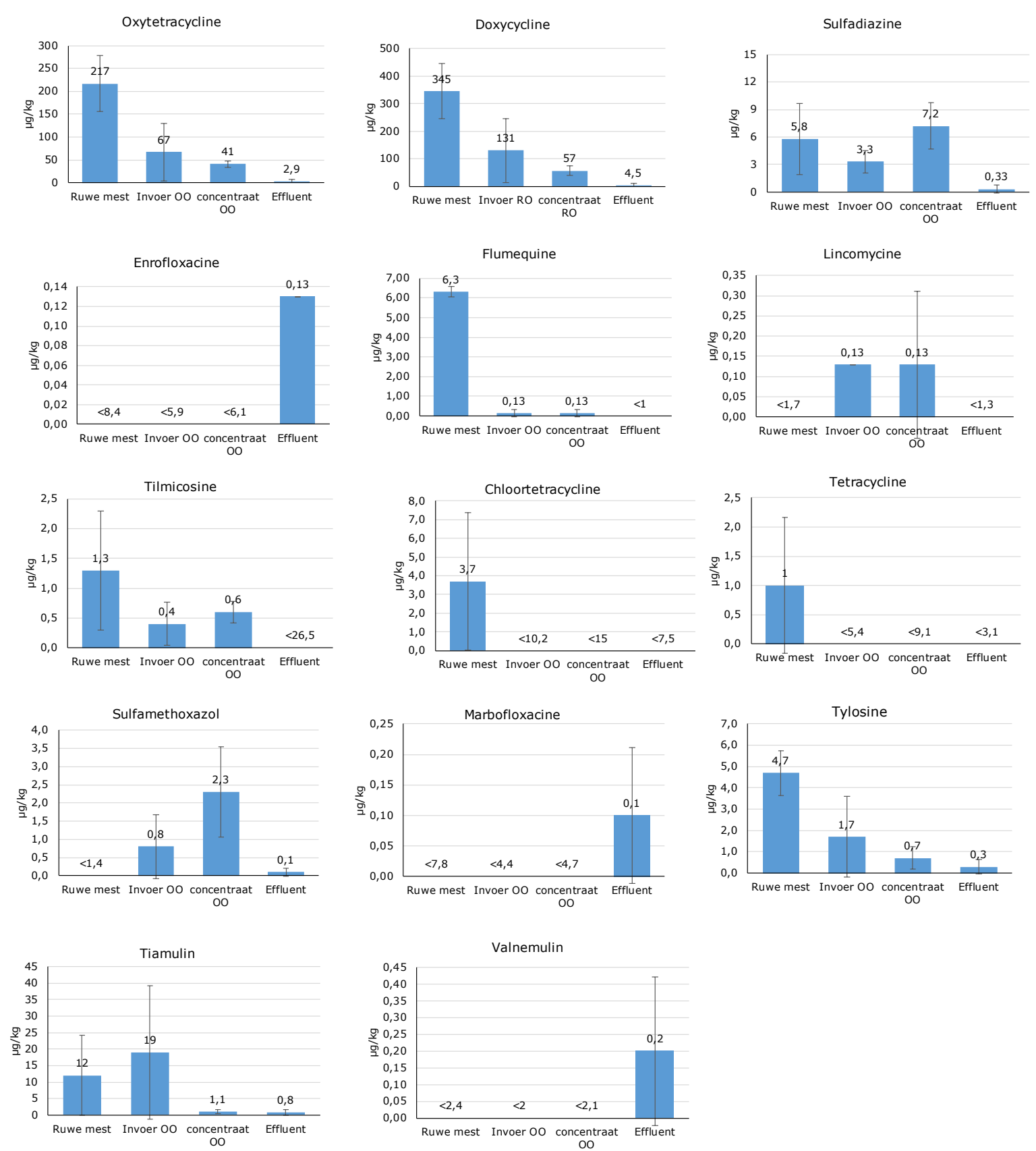

Figuur 3.11 Gemiddelde concentraties en variaties (plus en min 1 x standaarddeviatie) van antibiotica in processtromen van de OO-installaties. Alleen de parameters met ten minste één reële meetwaarde zijn in de figuur weergegeven.

Tabel 13 en Figuur 3.11 laten zien dat van de antibiotica die in meetbare concentraties in de ruwe mest aanwezig zijn na scheiding een gering deel wordt teruggevonden in de invoer van OO; het grootste deel blijft achter in de dikke fractie. De gehalten aan oxytetracycline en doxycycline in de invoer 00 zijn 70 resp. 60\% lager dan in de ruwe mest. Van deze stoffen, behorend tot de antibioticagroep tetracyclines, is bekend dat ze sterk aan vaste deeltjes binden (Sukul et al, 2007; Spielmeyer, 2018; Berendsen et al, 2018) waardoor ze bij scheiding grotendeels in de vaste fractie terechtkomen. Dit geldt ook voor de antibioticagroep quinolonen waartoe flumequine behoort.

Anders dan verwacht zijn de gehalten van een aantal antibiotica (oxytetracycline, doxycycline, tylosine en tiamuline) in het concentraat 00 in lagere concentraties aanwezig dan in de invoer OO. Dit duidt erop dat deze antibiotica niet goed bestand zijn tegen de bijzondere fysische condities (verhoogde druk en temperatuur) tijdens het omgekeerde osmose proces. Sulfadiazine en sulfamethoxazol lijken hier beter tegen bestand te zijn.

Tabel 13 laat zien dat slechts incidenteel (één van de 15 monsters) een aantal antibiotica in het effluent van $\mathrm{OO}$ is aangetroffen. In dit ene monster werd voor oxytetracycline en doxycycline een concentratie gemeten van 43 resp. $67 \mu \mathrm{g} / \mathrm{l}$. Deze incidentele piekwaarden overschrijden de PNEC 
waarden. Lahr et al (2014) hebben in het effluent van vier OO-installaties oxytetracycline niet in meetbare concentraties aangetroffen maar rapporteren voor doxycycline concentraties tussen 6 en 45 $\mu \mathrm{g} / \mathrm{kg}$.

Op grond van de in deze meetcampagne verkregen resultaten zouden oxytetracycline en doxycycline aangemerkt kunnen worden als indicatorstoffen voor effluent van MVI's met omgekeerde osmose als laatste behandelingsstap.

Tabel 14 Gemiddelde concentraties en standardafwijking van micro-organismen in processtromen van de OO-installaties. Tussen haakjes staat het aantal positieve waarnemingen en het totale aantal waarnemingen. Voor berekening van de gemiddelde concentratie is voor monsters met waarnemingen onder de detectielimiet deze limiet aangenomen. De eenheid is de decadische logaritme van de concentratie in KVE/g $(\log 10(\mathrm{KVE} / \mathrm{g})$. Betekenis van de letters in superscript: verschillende letters per regel betekent dat het verschil in concentratie in vergelijking met de ruwe mest significant is $(p<0,05)$.

\begin{tabular}{|c|c|c|c|c|c|c|c|c|c|c|c|c|c|}
\hline \multirow[b]{2}{*}{ E. coli } & \multicolumn{3}{|c|}{ Ruwe mest } & \multicolumn{2}{|l|}{ Invoer OO } & \multicolumn{3}{|c|}{ Concentraat OO } & \multicolumn{4}{|c|}{ Effluent } & \multirow[b]{2}{*}{ b $\quad(4 / 9)$} \\
\hline & 4,65 & $0,22 \quad a$ & $a \quad(5 / 5)$ & 3,98 & 0,13 & $\mathrm{~b}$ & $(8 / 8)$ & 3,95 & 0,25 & b $\quad(8 / 8)$ & $-2,73$ & 0,20 & \\
\hline Enterokokken & 4,59 & 0,14 a & $a \quad(5 / 5)$ & 3,39 & 0,23 & $\mathrm{~b}$ & $(8 / 8)$ & 3,54 & 0,30 & b $\quad(8 / 8)$ & $-2,78$ & 0,21 & b $(3 / 9)$ \\
\hline $\begin{array}{l}\text { Sporen van } \\
\text { sulfietreducerende } \\
\text { Clostridia }\end{array}$ & 4,85 & $0,14^{a}$ & a $(5 / 5)$ & 3,05 & 0,23 & $\mathrm{~b}$ & $(8 / 8)$ & 3,61 & 0,32 & b $(8 / 8)$ & $-2,30$ & 0,26 & b $(7 / 9)$ \\
\hline $\begin{array}{l}\text { Sporen van } C \text {. } \\
\text { difficile }\end{array}$ & 1,97 & $0,20 \quad a$ & a $(5 / 5)$ & 1,07 & 0,10 & $\mathrm{~b}$ & $(5 / 8)$ & 1,21 & 0,08 & b $(4 / 8)$ & $-3,03$ & 0,06 & b $(2 / 9)$ \\
\hline ESBL E. coli & 0,62 & 0,39 a & a $(1 / 4)$ & 0,32 & 0,19 & a & $(4 / 5)$ & 0,34 & 0,19 & a $(3 / 5)$ & $-3,20$ & & b $(0 / 6)$ \\
\hline Bacteriofagen & 5,44 & 0,08 a & a $(3 / 3)$ & 4,73 & 0,15 & a & $(4 / 4)$ & 4,95 & 0,05 & a $(4 / 4)$ & $-3,29$ & 0,43 & b $(4 / 4)$ \\
\hline Campylobacter & Aanwezig & & $(3 / 3)$ & Aanwezig & & & $(4 / 4)$ & Aanwezig & & $(2 / 4)$ & Afwezig & & $(0 / 4)$ \\
\hline MRSA & Afwezig & & $(0 / 3)$ & Afwezig & & & $(0 / 5)$ & Afwezig & & $(0 / 4)$ & Afwezig & & $(0 / 5)$ \\
\hline Hepatitis E virus & Aanwezig & & $(3 / 3)$ & Aanwezig & & & $(3 / 4)$ & Aanwezig & & $(4 / 4)$ & Afwezig & & $(0 / 4)$ \\
\hline
\end{tabular}

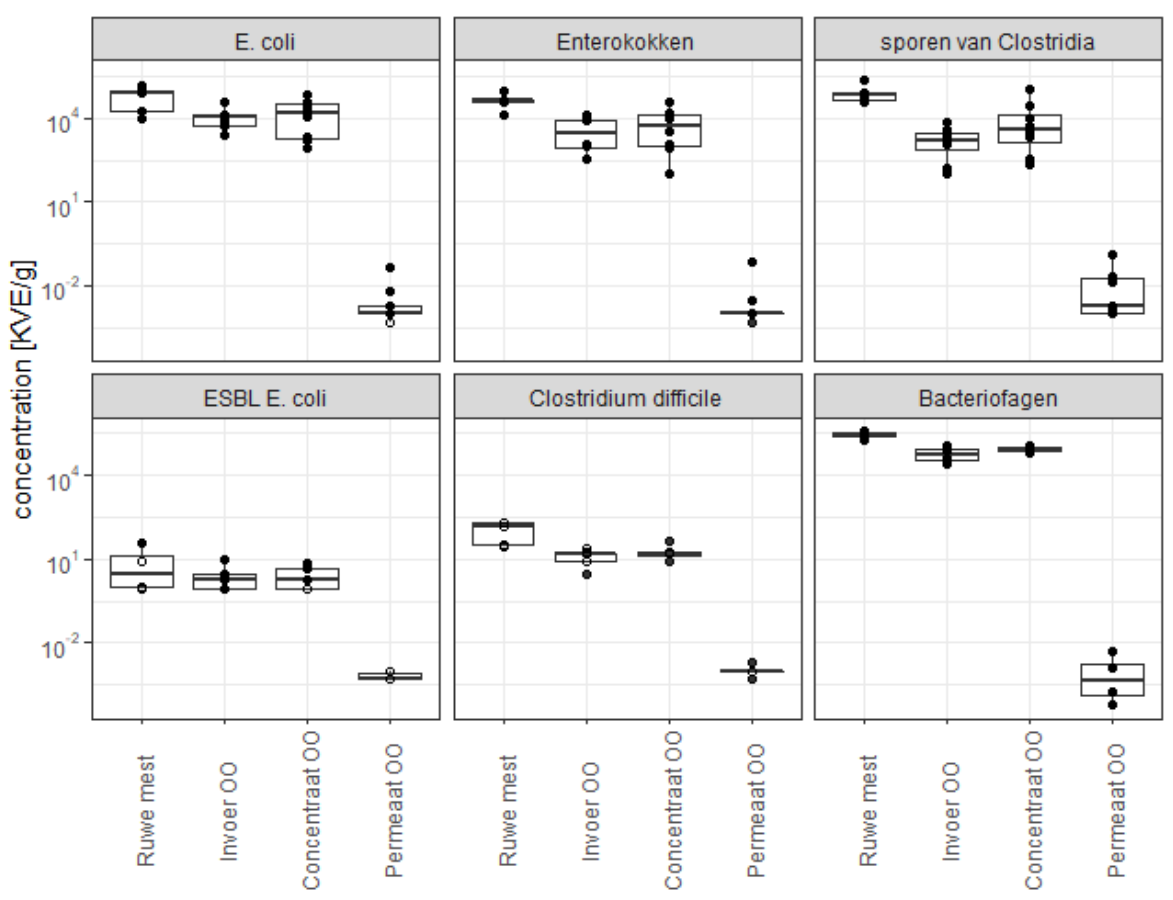

Figuur 3.12 Concentraties en hun variatie (mediaan als horizontale lijn, 25-75 percentiel als box, uitschieters als punten met een verticale verbinding naar de box) van micro-organismen in processtromen van de OO-installaties. Waarden onder de detectielimiet zijn vervangen door de detectielimiet en met open symbolen aangeduid, waarden boven de detectielimiet zijn door gevulde symbolen aangeduid. 
Tabel 14 en Figuur 3.12 tonen dat scheiding van ruwe mest een dunne fractie oplevert met hoge concentraties aan micro-organismen. Deze worden voor het overgrote deel afgevangen door oo en komen in het concentraat terecht. Het effluent bevat slechts lage concentraties micro-organismen. De vooraf aangemerkte indicatoren voor bacteriën, sporevormende bacteriën en virussen blijken daarmee inderdaad allemaal geschikt te zijn als indicator organisme. Hepatitis E virus en Campylobacter waren beide aantoonbaar in de ruwe mest, in invoer en concentraat van 00 , maar niet in het effluent. MRSA is in geen van de monsters aangetroffen, waaruit blijkt dat omgekeerde osmose zeer effectief is voor het verwijderen van bacteriën en virussen. 


\subsection{Samenstelling van processtromen MBR-UF}

Tabel 15 Gemiddelde gehalten van algemene chemische parameters in processtromen van de MBR-UFinstallatie. Betekenis van de letters in superscript: verschillende letters per regel betekent dat het verschil in gehalte tussen processtromen significant is $(P<0,05)$. Tussen haakjes staat het aantal waarnemingen $>$ detectiegrens en het totale aantal waarnemingen.

\begin{tabular}{|c|c|c|c|c|c|c|c|c|c|}
\hline \multirow{2}{*}{$\begin{array}{l}\text { Parameter } \\
\text { BZV }\end{array}$} & \multirow{2}{*}{$\begin{array}{l}\text { Eenheid } \\
\text { mg/l }\end{array}$} & \multicolumn{2}{|c|}{ Ruwe mest } & \multicolumn{2}{|c|}{ Invoer MBR } & \multicolumn{2}{|c|}{ Invoer UF } & \multicolumn{2}{|c|}{ Effluent } \\
\hline & & 8424 & a $(5 / 5)$ & 4218 & b $\quad(5 / 5)$ & 1818 & c $(5 / 5)$ & 8 & d $(5 / 5)$ \\
\hline $\mathrm{CZV}$ & $\mathrm{mg} / \mathrm{l}$ & 65140 & a $(5 / 5)$ & 11290 & b $\quad(5 / 5)$ & 18560 & b $\quad(5 / 5)$ & 744 & c $(5 / 5)$ \\
\hline Onopgeloste stoffen & $\mathrm{mg} / \mathrm{l}$ & NA & $(0 / 0)$ & 1500 & a $(1 / 1)$ & 19000 & b $\quad(1 / 1)$ & 7,7 & c $(3 / 5)$ \\
\hline P-totaal & $\mathrm{mg} / \mathrm{kg}$ & 1255 & a $(3 / 3)$ & 133 & b $(3 / 3)$ & 493 & c $(3 / 3)$ & 5,3 & d $(3 / 3)$ \\
\hline $\mathrm{P}-\mathrm{PO}_{4}$ & $\mathrm{mg} / \mathrm{kg}$ & 238 & a $(3 / 3)$ & 101 & b $(3 / 3)$ & 51 & c $(3 / 3)$ & 8,3 & d $(3 / 3)$ \\
\hline $\mathrm{N}$-totaal & $\mathrm{mg} / \mathrm{kg}$ & 5027 & a $(3 / 3)$ & 3222 & b $(3 / 3)$ & 1271 & c $(3 / 3)$ & 51 & d $(3 / 3)$ \\
\hline $\mathrm{N}-\mathrm{NH}_{4}$ & $\mathrm{mg} / \mathrm{kg}$ & 3040 & a $(3 / 3)$ & 2766 & a $(3 / 3)$ & 91 & b $(3 / 3)$ & 21 & b $(3 / 3)$ \\
\hline $\mathrm{NO}_{2}-\mathrm{N}+\mathrm{NO}_{3}-\mathrm{N}$ & $\mathrm{mg} / \mathrm{kg}$ & 2,6 & a $(3 / 3)$ & 2,1 & a $(3 / 3)$ & 29 & a $(3 / 3)$ & 10 & a $(3 / 3)$ \\
\hline $\mathrm{pH}$ & - & 7,8 & a $(3 / 3)$ & 8 & b $(3 / 3)$ & 7,9 & b $(3 / 3)$ & 8,6 & c $(3 / 3)$ \\
\hline EC & $\mathrm{mS} / \mathrm{cm}$ & 23 & a $(3 / 3)$ & 28 & b $(3 / 3)$ & 11 & c $(3 / 3)$ & 8,4 & c $(3 / 3)$ \\
\hline $\mathrm{Cl}-$ & $\mathrm{mg} / \mathrm{kg}$ & 1970 & a $(5 / 5)$ & 1617 & a $(5 / 5)$ & 1862 & a $(5 / 5)$ & 1588 & a $(5 / 5)$ \\
\hline $\mathrm{S}$ & $\mathrm{mg} / \mathrm{kg}$ & 777 & a $(3 / 3)$ & 250 & b $\quad(3 / 3)$ & 430 & c $(3 / 3)$ & 103 & d $(3 / 3)$ \\
\hline $\mathrm{K}$ & $\mathrm{mg} / \mathrm{kg}$ & 3600 & a $(3 / 3)$ & 3367 & a $(3 / 3)$ & 3267 & a $(3 / 3)$ & 2033 & b $(3 / 3)$ \\
\hline
\end{tabular}



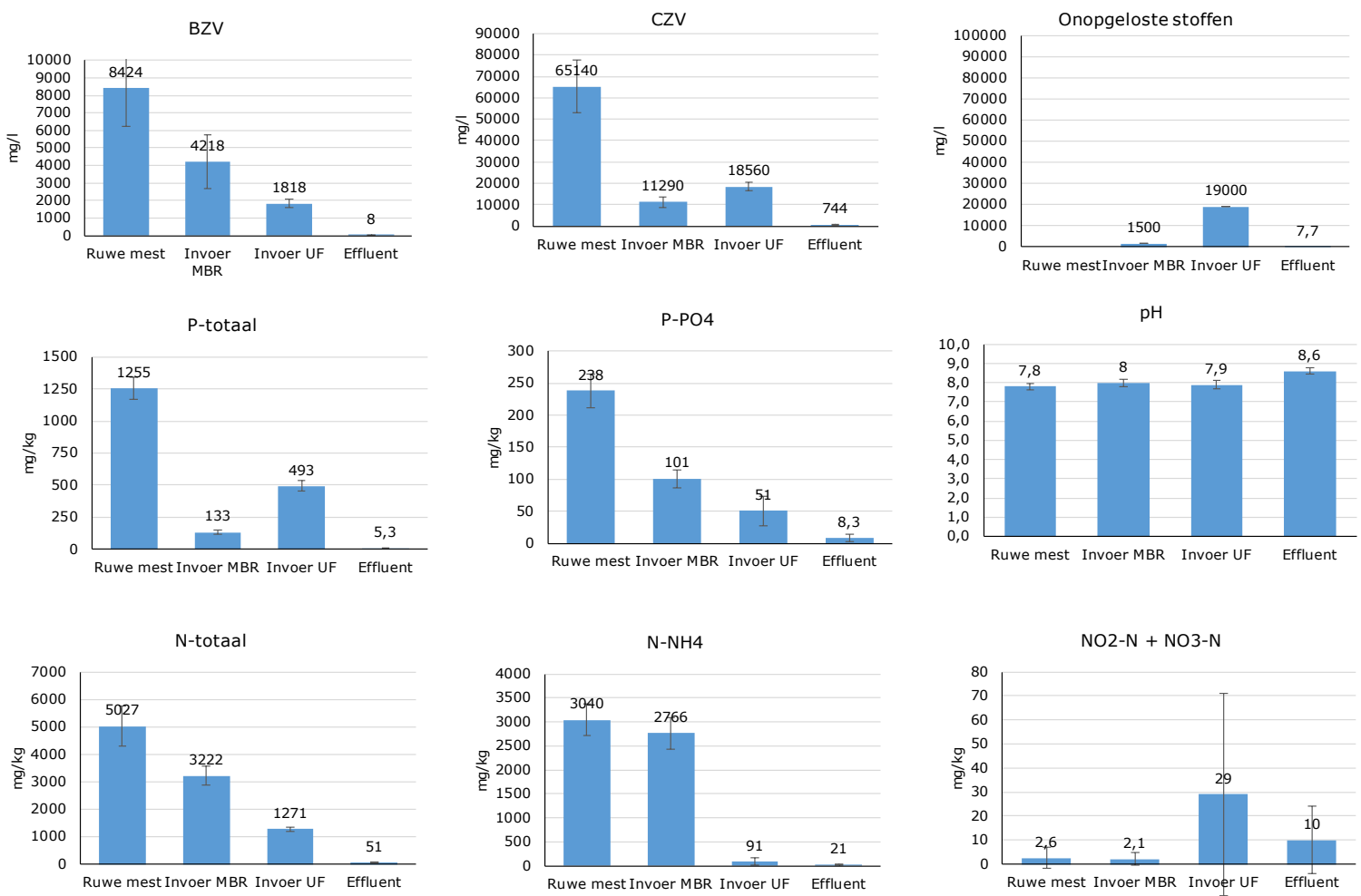

$\mathrm{S}$
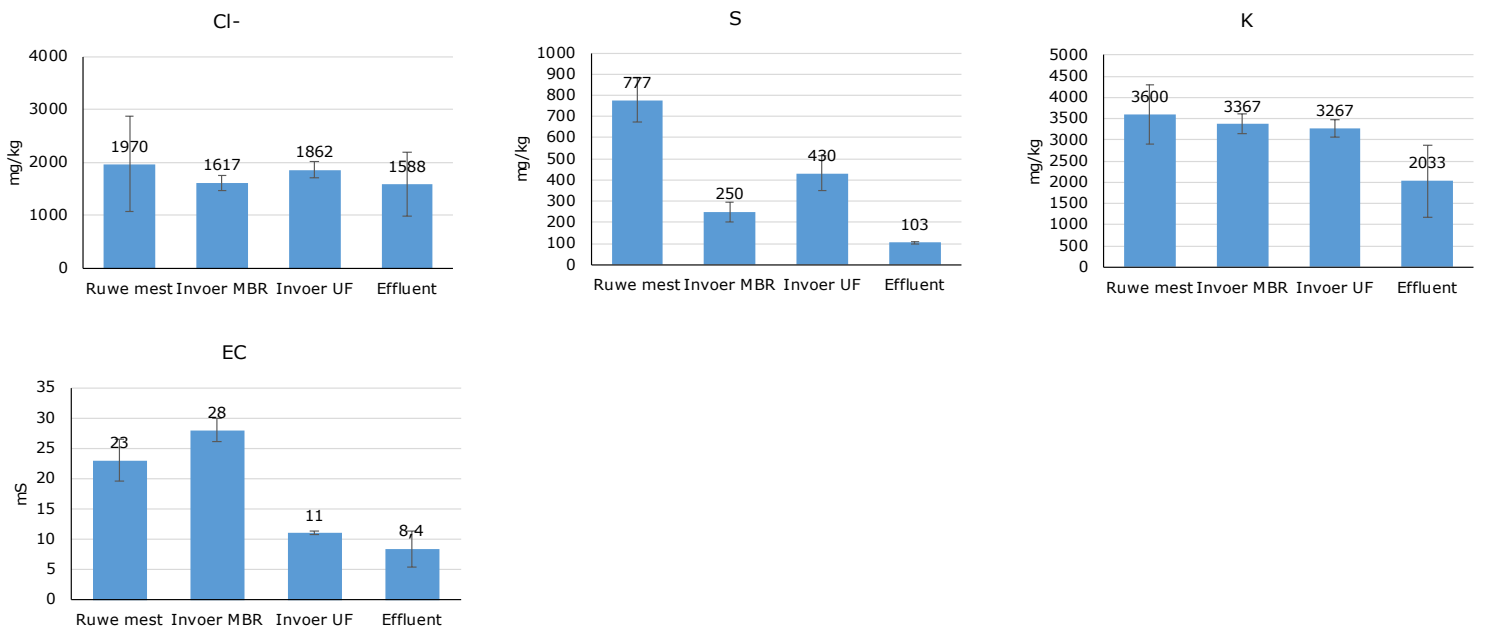

Figuur 3.13 Gemiddelde gehalten en variaties (plus en min 1 x standaarddeviatie) van algemene chemische parameters in processtromen van de MBR-UF installatie.

Scheiding van de ruwe mest door middel van de zeefbandpers resulteert in lagere gehalten van de algemene chemische parameters. Het effect van biologische behandeling is wisselend; BZV neemt evenals $\mathrm{P}_{-} \mathrm{PO}_{4}$ met de helft af, van $\mathrm{N}$-totaal resteert $40 \%$ en van de aanwezige ammonium blijft $3 \%$ over. Van de andere (niet biologisch afbreekbare) parameters zijn de gehalten in de invoer UF hoger dan in de invoer MBR. Dit kan worden verklaard door het gegeven dat het monster van de invoer UF is genomen uit de denitrificatietank waarin de UF-unit zich bevindt. Het monster kan daardoor een relatief grote hoeveelheid slib bevatten. Lagere gehalten in het effluent waren te verwachten. Het effluent bevat nog een aanzienlijke hoeveelheid CZV (door o.a. humuszuren), chloride en kalium. 
Tabel 16 Gemiddelde concentraties van zware metalen in processtromen van de MBR-UF-installatie. Betekenis van de letters in superscript: verschillende letters per regel betekent dat het verschil in concentratie tussen processtromen significant is $(P<0,05)$. Tussen haakjes staat het aantal waarnemingen $>$ detectiegrens en het totale aantal waarnemingen.

\begin{tabular}{|c|c|c|c|c|c|c|c|c|c|}
\hline Parameter & Eenheid & Ruwe mest & Invoer & MBR & Invoer & UF & & Effluen & \\
\hline $\mathrm{Cd}$ & $\mathrm{mg} / \mathrm{kg}$ & 0,03 a $(3 / 3)$ & $<0,027$ & b $(0 / 3)$ & $<0,027$ & $\mathrm{~b}$ & $(0 / 3)$ & $<0,027$ & b $\quad(0 / 3)$ \\
\hline $\mathrm{Hg}$ & $\mathrm{mg} / \mathrm{kg}$ & $<0,012$ a $(0 / 3)$ & $<0,012$ & a $(0 / 3)$ & $<0,012$ & a & $(0 / 3)$ & $<0,012$ & a $(0 / 3)$ \\
\hline $\mathrm{Pb}$ & $\mathrm{mg} / \mathrm{kg}$ & 0,08 a $(3 / 3)$ & $<0,013$ & b $(0 / 3)$ & $<0,013$ & $\mathrm{~b}$ & $(0 / 3)$ & $<0,013$ & b $\quad(0 / 3)$ \\
\hline As & $\mathrm{mg} / \mathrm{kg}$ & $<0,11$ a $(0 / 3)$ & $<0,11$ & a $(0 / 3)$ & $<0,11$ & a & $(0 / 3)$ & $<0,11$ a & a $(0 / 3)$ \\
\hline $\mathrm{Cr}$ & $\mathrm{mg} / \mathrm{kg}$ & 0,58 a $(3 / 3)$ & 0,03 & b $(1 / 3)$ & 0,41 & c & $(3 / 3)$ & $<0,074$ & b $\quad(0 / 3)$ \\
\hline $\mathrm{Ni}$ & $\mathrm{mg} / \mathrm{kg}$ & 0,64 a $(3 / 3)$ & 0,25 & b $(3 / 3)$ & 0,61 & a & $(3 / 3)$ & 0,04 & c $(1 / 3)$ \\
\hline $\mathrm{Cu}$ & $\mathrm{mg} / \mathrm{kg}$ & 12 a $(3 / 3)$ & $<0,57$ & b $(0 / 3)$ & 1 & c & $(3 / 3)$ & $<0,57$ b & b $\quad(0 / 3)$ \\
\hline$Z n$ & $\mathrm{mg} / \mathrm{kg}$ & 46 a $(3 / 3)$ & 1,2 & bc $(2 / 3)$ & 3,8 & c & $(3 / 3)$ & $<1,1$ & b $\quad(0 / 3)$ \\
\hline $\mathrm{Ba}$ & $\mathrm{mg} / \mathrm{kg}$ & 2,4 a $(3 / 3)$ & 0,07 & b $(1 / 3)$ & 0,53 & c & $(3 / 3)$ & $<0,16$ & b $\quad(0 / 3)$ \\
\hline v & $\mathrm{mg} / \mathrm{kg}$ & 0,32 a $(1 / 1)$ & $<0,28$ & b $(0 / 1)$ & 0,54 & $\mathrm{a}$ & $(1 / 1)$ & $<0,28$ b & b $\quad(0 / 1)$ \\
\hline U & $\mathrm{mg} / \mathrm{kg}$ & $<0,062$ a $(0 / 1)$ & $<0,062$ & a $(0 / 1)$ & $<0,062$ & $\mathrm{a}$ & $(0 / 1)$ & $<0,062$ & a $\quad(0 / 1)$ \\
\hline Co & $\mathrm{mg} / \mathrm{kg}$ & 0,15 a $(3 / 3)$ & NA & $(0 / 0)$ & NA & & $(0 / 0)$ & 0,02 b & b $(3 / 3)$ \\
\hline $\mathrm{Se}$ & $\mathrm{mg} / \mathrm{kg}$ & 0,3 a $(3 / 3)$ & NA & $(0 / 0)$ & NA & & $(0 / 0)$ & $<0,032$ & b $\quad(0 / 3)$ \\
\hline
\end{tabular}



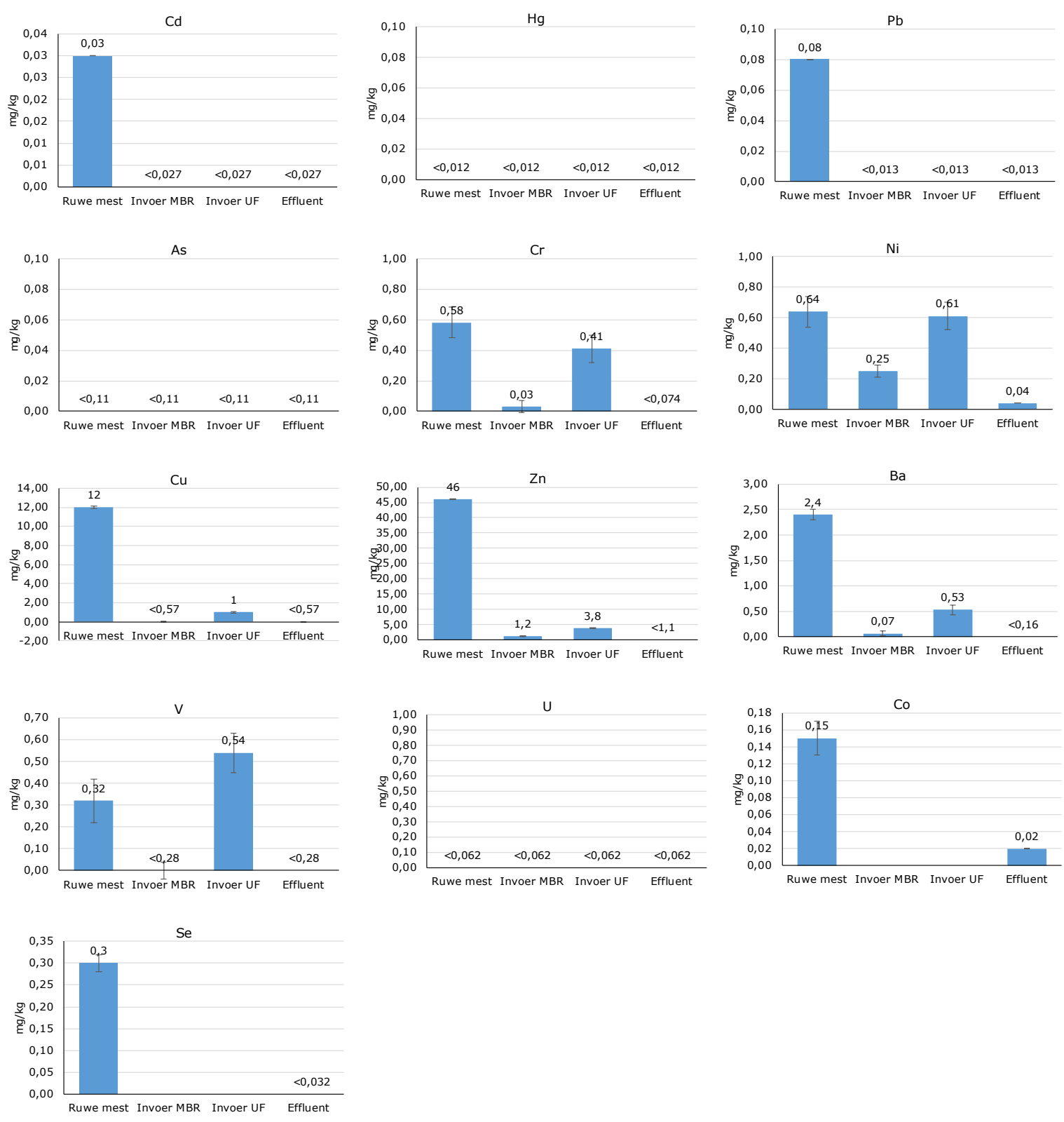

Figuur 3.14 Gemiddelde concentraties en variaties (plus en min 1 x standaarddeviatie) van zware metalen in processtromen van de MBR-UF-installatie.

De meeste in de ruwe mest aanwezige zware metalen worden door de voorscheiding met de zeefbandpers vergaand verwijderd. Dit is overeenkomstig de bevindingen bij 00 . Evenals een aantal algemene parameters zijn de metalen chroom, nikkel, koper, zink, barium en vanadium in de invoer UF in hogere concentraties aanwezig dan in de invoer MBR, waarvoor dezelfde verklaring kan worden gegeven. In het effluent van de MBR-UF installatie zijn nog nikkel en kobalt aangetroffen. De andere metalen zijn niet aangetoond, wat mede te maken heeft met de relatief hoge detectiegrens van de toegepaste analysemethode. 
Tabel 17 Gemiddelde concentraties van hormoonstoffen en antibiotica in processtromen van de MBRUF-installatie. Waarden boven de detectiegrens zijn vetgedrukt. Betekenis van de letters in superscript: verschillende letters per regel betekent dat het verschil in concentratie tussen processtromen significant is $(P<0,05)$. Tussen haakjes staat het aantal waarnemingen $>$ detectiegrens en het totale aantal waarnemingen.

\begin{tabular}{|c|c|c|c|c|c|c|c|c|c|c|c|}
\hline \multirow{2}{*}{$\begin{array}{r}\text { Parameter } \\
\text { Hormoonstoffen }\end{array}$} & Eenheid & \multicolumn{3}{|c|}{ Ruwe mest } & \multicolumn{3}{|c|}{ Invoer MBR } & \multicolumn{2}{|c|}{ Invoer UF } & \multicolumn{2}{|c|}{ Effluent } \\
\hline & & & & & & & & & & & \\
\hline ER-CALUX & $17 B \mathrm{EEQ} / \mathrm{g}$ & 9,5 & a & $(4 / 4)$ & 0,5 & $\mathrm{~b}$ & $(4 / 4)$ & 0,01 & b $\quad(4 / 4)$ & 0,00028 & b $(2 / 4)$ \\
\hline \multicolumn{12}{|l|}{ Antibiotica } \\
\hline Oxytetracycline & $\mu \mathrm{g} / \mathrm{kg}$ & 89 & $a$ & $(5 / 5)$ & 7,4 & $\mathrm{~b}$ & $(3 / 5)$ & 5,2 & b $\quad(5 / 5)$ & $<1,6$ & b $(0 / 5)$ \\
\hline Doxycycline & $\mu \mathrm{g} / \mathrm{kg}$ & 155 & $\mathrm{a}$ & $(5 / 5)$ & 15 & $\mathrm{~b}$ & $(5 / 5)$ & 15 & b $\quad(5 / 5)$ & 1,2 & b $(2 / 5)$ \\
\hline Sulfadiazine & $\mu \mathrm{g} / \mathrm{kg}$ & 15 & a & $(4 / 5)$ & 12 & a & $(4 / 5)$ & 0,2 & b $\quad(1 / 5)$ & $<1$ & b $(0 / 5)$ \\
\hline Sulfadimidine & $\mu \mathrm{g} / \mathrm{kg}$ & $<1$ & $\mathrm{a}$ & $(0 / 5)$ & $<1$ & $\mathrm{a}$ & $(0 / 5)$ & $<1$ & a $(0 / 5)$ & $<1$ & a $(0 / 5)$ \\
\hline Trimethoprim & $\mu \mathrm{g} / \mathrm{kg}$ & $<1,4$ & $\mathrm{a}$ & $(0 / 5)$ & $<1$ & $\mathrm{a}$ & $(0 / 5)$ & $<1$ & a $(0 / 5)$ & $<1$ & a $(0 / 5)$ \\
\hline Ciprofloxacine & $\mu \mathrm{g} / \mathrm{kg}$ & $<5,4$ & $\mathrm{a}$ & $(0 / 5)$ & $<2$ & $\mathrm{a}$ & $(0 / 5)$ & $<1$ & a $(0 / 5)$ & $<1$ & a $(0 / 5)$ \\
\hline Enrofloxacine & $\mu \mathrm{g} / \mathrm{kg}$ & $<6,6$ & a & $(0 / 5)$ & $<3$ & a & $(0 / 5)$ & $<1,6$ & a $(0 / 5)$ & $<1,2$ & a $(0 / 5)$ \\
\hline Flumequine & $\mu \mathrm{g} / \mathrm{kg}$ & $<1,2$ & $\mathrm{a}$ & $(0 / 5)$ & $<1$ & $\mathrm{a}$ & $(0 / 5)$ & $<1$ & a $(0 / 5)$ & $<1$ & a $(0 / 5)$ \\
\hline Lincomycine & $\mu \mathrm{g} / \mathrm{kg}$ & $<1,8$ & a & $(0 / 5)$ & $<1,6$ & a & $(0 / 5)$ & $<1,2$ & a $(0 / 5)$ & $<1$ & a $(0 / 5)$ \\
\hline Tilmicosine & $\mu \mathrm{g} / \mathrm{kg}$ & 0,6 & $\mathrm{a}$ & $(1 / 5)$ & $<1,8$ & $\mathrm{~b}$ & $(0 / 5)$ & $<3$ & b $\quad(0 / 5)$ & $<20$ & b $(0 / 5)$ \\
\hline Florfenicol & $\mu \mathrm{g} / \mathrm{kg}$ & $<1,8$ & $\mathrm{a}$ & $(0 / 5)$ & $<1,4$ & a & $(0 / 5)$ & $<1,2$ & a $(0 / 5)$ & $<1,2$ & a $(0 / 5)$ \\
\hline Chloortetracycline & $\mu \mathrm{g} / \mathrm{kg}$ & $<7,5$ & $\mathrm{a}$ & $(0 / 2)$ & $<4$ & a & $(0 / 2)$ & $<1$ & $(0 / 2)$ & $<1$ & a $(0 / 2)$ \\
\hline Tetracycline & $\mu \mathrm{g} / \mathrm{kg}$ & $<5$ & a & $(0 / 2)$ & $<5$ & $\mathrm{a}$ & $(0 / 2)$ & $<1,5$ & a $(0 / 2)$ & $<1$ & a $(0 / 2)$ \\
\hline Minocycline & $\mu \mathrm{g} / \mathrm{kg}$ & $<25$ & $a$ & $(0 / 2)$ & $<18$ & a & $(0 / 2)$ & $<5$ & a $(0 / 2)$ & $<4$ & a $(0 / 2)$ \\
\hline Methacycline & $\mu \mathrm{g} / \mathrm{kg}$ & $<10$ & a & $(0 / 2)$ & $<5$ & $a$ & $(0 / 2)$ & $<1,5$ & a $(0 / 2)$ & $<1$ & a $(0 / 2)$ \\
\hline Sulfathiazol & $\mu \mathrm{g} / \mathrm{kg}$ & $<7,5$ & $\mathrm{a}$ & $(0 / 2)$ & $<4$ & a & $(0 / 2)$ & $<2$ & a $(0 / 2)$ & $<2$ & a $(0 / 2)$ \\
\hline Sulfapyridine & $\mu \mathrm{g} / \mathrm{kg}$ & $<3$ & $\mathrm{a}$ & $(0 / 2)$ & $<2,5$ & a & $(0 / 2)$ & $<1$ & a $(0 / 2)$ & $<1$ & ${ }^{a}(0 / 2)$ \\
\hline Sulfamerazine & $\mu \mathrm{g} / \mathrm{kg}$ & $<1$ & a & $(0 / 2)$ & $<1$ & a & $(0 / 2)$ & $<1$ & a $(0 / 2)$ & $<1$ & a $(0 / 2)$ \\
\hline Sulfamoxol & $\mu \mathrm{g} / \mathrm{kg}$ & $<1$ & a & $(0 / 2)$ & $<1$ & $\mathrm{a}$ & $(0 / 2)$ & $<1$ & a $(0 / 2)$ & $<1$ & a $(0 / 2)$ \\
\hline Sulfamethizol & $\mu \mathrm{g} / \mathrm{kg}$ & $<1$ & a & $(0 / 2)$ & $<1$ & a & $(0 / 2)$ & $<1$ & a $(0 / 2)$ & $<1$ & a $(0 / 2)$ \\
\hline Sulfamethoxypyridazine & $\mu \mathrm{g} / \mathrm{kg}$ & $<1$ & $a$ & $(0 / 2)$ & $<1$ & a & $(0 / 2)$ & $<1$ & a $(0 / 2)$ & $<1$ & a $(0 / 2)$ \\
\hline Sulfamonomethoxine & $\mu \mathrm{g} / \mathrm{kg}$ & $<1$ & a & $(0 / 2)$ & $<1$ & a & $(0 / 2)$ & $<1$ & a $(0 / 2)$ & $<1$ & a $(0 / 2)$ \\
\hline Sulfachloorpyridazine & $\mu \mathrm{g} / \mathrm{kg}$ & $<2$ & a & $(0 / 2)$ & $<2$ & $\mathrm{a}$ & $(0 / 2)$ & $<1$ & a $(0 / 2)$ & $<1$ & a $(0 / 2)$ \\
\hline Sulfadoxine & $\mu \mathrm{g} / \mathrm{kg}$ & $<1$ & a & $(0 / 2)$ & $<1$ & $\mathrm{a}$ & $(0 / 2)$ & $<1$ & a $(0 / 2)$ & $<1$ & a $(0 / 2)$ \\
\hline Sulfamethoxazol & $\mu \mathrm{g} / \mathrm{kg}$ & $<1$ & $\mathrm{a}$ & $(0 / 2)$ & $<1$ & $\mathrm{a}$ & $(0 / 2)$ & $<1$ & a $(0 / 2)$ & $<1$ & a $(0 / 2)$ \\
\hline Sulfisoxazol & $\mu \mathrm{g} / \mathrm{kg}$ & $<2$ & $a$ & $(0 / 2)$ & $<2$ & $\mathrm{a}$ & $(0 / 2)$ & $<1$ & a $(0 / 2)$ & $<1$ & a $(0 / 2)$ \\
\hline Sulfadimethoxine & $\mu \mathrm{g} / \mathrm{kg}$ & $<1$ & $a$ & $(0 / 2)$ & $<1$ & $\mathrm{a}$ & $(0 / 2)$ & $<1$ & a $(0 / 2)$ & $<1$ & a $(0 / 2)$ \\
\hline Sulfaquinoxaline & $\mu \mathrm{g} / \mathrm{kg}$ & $<2$ & a & $(0 / 2)$ & $<1$ & a & $(0 / 2)$ & $<1$ & a $(0 / 2)$ & $<1$ & a $(0 / 2)$ \\
\hline Sulfacetamide & $\mu \mathrm{g} / \mathrm{kg}$ & $<1$ & $a$ & $(0 / 2)$ & $<1$ & $\mathrm{a}$ & $(0 / 2)$ & $<1$ & a $(0 / 2)$ & $<1$ & a $(0 / 2)$ \\
\hline Sulfaphenazol & $\mu \mathrm{g} / \mathrm{kg}$ & $<10$ & $a$ & $(0 / 2)$ & $<7,5$ & a & $(0 / 2)$ & $<2$ & a $(0 / 2)$ & $<2$ & ${ }^{a}(0 / 2)$ \\
\hline Dapson & $\mu \mathrm{g} / \mathrm{kg}$ & $<1$ & $\mathrm{a}$ & $(0 / 2)$ & $<1$ & a & $(0 / 2)$ & $<1$ & a $(0 / 2)$ & $<1$ & a $(0 / 2)$ \\
\hline Marbofloxacine & $\mu \mathrm{g} / \mathrm{kg}$ & $<7,5$ & $\mathrm{a}$ & $(0 / 2)$ & $<4$ & a & $(0 / 2)$ & $<1,5$ & a $(0 / 2)$ & $<1$ & a $(0 / 2)$ \\
\hline Norfloxacine & $\mu \mathrm{g} / \mathrm{kg}$ & $<12$ & $\mathrm{a}$ & $(0 / 2)$ & $<7,5$ & a & $(0 / 2)$ & $<2$ & a $(0 / 2)$ & $<1,5$ & a $(0 / 2)$ \\
\hline Danofloxacine & $\mu \mathrm{g} / \mathrm{kg}$ & $<12$ & a & $(0 / 2)$ & $<5$ & a & $(0 / 2)$ & $<2$ & a $(0 / 2)$ & $<1,5$ & a $(0 / 2)$ \\
\hline Sarafloxacine & $\mu \mathrm{g} / \mathrm{kg}$ & $<25$ & a & $(0 / 2)$ & $<10$ & a & $(0 / 2)$ & $<5$ & a $(0 / 2)$ & $<5$ & a $(0 / 2)$ \\
\hline Difloxacine & $\mu \mathrm{g} / \mathrm{kg}$ & $<10$ & a & $(0 / 2)$ & $<3$ & $a$ & $(0 / 2)$ & $<1,5$ & a $(0 / 2)$ & $<1$ & a $(0 / 2)$ \\
\hline Oxolinezuur & $\mu \mathrm{g} / \mathrm{kg}$ & $<4$ & $\mathrm{a}$ & $(0 / 2)$ & $<3$ & a & $(0 / 2)$ & $<1$ & a $(0 / 2)$ & $<1$ & a $(0 / 2)$ \\
\hline Nalidixinezuur & $\mu \mathrm{g} / \mathrm{kg}$ & $<2$ & $\mathrm{a}$ & $(0 / 2)$ & $<2$ & a & $(0 / 2)$ & $<1$ & a $(0 / 2)$ & $<1$ & a $(0 / 2)$ \\
\hline Levofloxacin/ofloxacin & $\mu \mathrm{g} / \mathrm{kg}$ & $<5$ & $\mathrm{a}$ & $(0 / 2)$ & $<5$ & a & $(0 / 2)$ & $<5$ & a $(0 / 2)$ & $<5$ & a $(0 / 2)$ \\
\hline Trovafloxacin & $\mu \mathrm{g} / \mathrm{kg}$ & $<4$ & a & $(0 / 2)$ & $<1,5$ & a & $(0 / 2)$ & $<1$ & a $(0 / 2)$ & $<1$ & a $(0 / 2)$ \\
\hline Erythromycine & $\mu \mathrm{g} / \mathrm{kg}$ & $<5$ & $\mathrm{a}$ & $(0 / 2)$ & $<5$ & $\mathrm{a}$ & $(0 / 2)$ & $<1$ & a $(0 / 2)$ & $<1$ & a $(0 / 2)$ \\
\hline
\end{tabular}




\begin{tabular}{|c|c|c|c|c|c|c|c|c|c|c|c|c|}
\hline Tylosine & $\mu \mathrm{g} / \mathrm{kg}$ & 5,5 & a & $(2 / 2)$ & $<2,5$ & a & $(0 / 2)$ & $<1,5$ & a & $(0 / 2)$ & $<2$ & a $(0 / 2)$ \\
\hline Josamycine & $\mu \mathrm{g} / \mathrm{kg}$ & $<1$ & a & $(0 / 2)$ & $<1$ & a & $(0 / 2)$ & $<1$ & a & $(0 / 2)$ & $<1$ & a $(0 / 2)$ \\
\hline Spiramycine & $\mu \mathrm{g} / \mathrm{kg}$ & $<5$ & a & $(0 / 2)$ & $<5$ & $\mathrm{a}$ & $(0 / 2)$ & $<1,5$ & $\mathrm{a}$ & $(0 / 2)$ & $<2$ & a $(0 / 2)$ \\
\hline Neospiramycine 1 & $\mu \mathrm{g} / \mathrm{kg}$ & $<2,5$ & a & $(0 / 2)$ & $<2,5$ & $\mathrm{a}$ & $(0 / 2)$ & $<2,5$ & $\mathrm{a}$ & $(0 / 2)$ & $<3,5$ & a $(0 / 2)$ \\
\hline Tiamulin & $\mu \mathrm{g} / \mathrm{kg}$ & $<2$ & a & $(0 / 2)$ & $<2$ & a & $(0 / 2)$ & $<1$ & $\mathrm{a}$ & $(0 / 2)$ & $<1$ & a $(0 / 2)$ \\
\hline Tulathromycine & $\mu \mathrm{g} / \mathrm{kg}$ & $<1$ & a & $(0 / 2)$ & $<1$ & a & $(0 / 2)$ & $<1$ & $a$ & $(0 / 2)$ & $<2$ & a $(0 / 2)$ \\
\hline Pirlimycine & $\mu \mathrm{g} / \mathrm{kg}$ & $<1$ & a & $(0 / 2)$ & $<1$ & a & $(0 / 2)$ & $<1$ & a & $(0 / 2)$ & $<1$ & a $(0 / 2)$ \\
\hline Valnemulin & $\mu \mathrm{g} / \mathrm{kg}$ & $<1$ & a & $(0 / 2)$ & $<1$ & a & $(0 / 2)$ & $<1$ & a & $(0 / 2)$ & $<1$ & a $(0 / 2)$ \\
\hline Tylvalosine & $\mu \mathrm{g} / \mathrm{kg}$ & $<1$ & a & $(0 / 2)$ & $<1$ & a & $(0 / 2)$ & $<1$ & $\mathrm{a}$ & $(0 / 2)$ & $<1,5$ & a $(0 / 2)$ \\
\hline Natamycin & $\mu \mathrm{g} / \mathrm{kg}$ & $<2$ & a & $(0 / 2)$ & $<2$ & a & $(0 / 2)$ & $<1$ & a & $(0 / 2)$ & $<1$ & a $(0 / 2)$ \\
\hline Gamithromycine & $\mu \mathrm{g} / \mathrm{kg}$ & $<1$ & $a$ & $(0 / 2)$ & $<1$ & a & $(0 / 2)$ & $<1$ & $\mathrm{a}$ & $(0 / 2)$ & $<2$ & a $(0 / 2)$ \\
\hline Tildipirosine & $\mu \mathrm{g} / \mathrm{kg}$ & $<5$ & a & $(0 / 2)$ & $<1$ & a & $(0 / 2)$ & $<1,5$ & $\mathrm{a}$ & $(0 / 2)$ & $<3,5$ & a $(0 / 2)$ \\
\hline Vancomycine & $\mu \mathrm{g} / \mathrm{kg}$ & $<4$ & $\mathrm{a}$ & $(0 / 2)$ & $<3$ & a & $(0 / 2)$ & $<1$ & a & $(0 / 2)$ & $<1$ & a $(0 / 2)$ \\
\hline Azithromycine & $\mu \mathrm{g} / \mathrm{kg}$ & $<1$ & $\mathrm{a}$ & $(0 / 2)$ & $<1$ & a & $(0 / 2)$ & $<1$ & $\mathrm{a}$ & $(0 / 2)$ & $<1$ & a $(0 / 2)$ \\
\hline Clarithromycine & $\mu \mathrm{g} / \mathrm{kg}$ & $<1$ & $\mathrm{a}$ & $(0 / 2)$ & $<1$ & a & $(0 / 2)$ & $<1$ & $\mathrm{a}$ & $(0 / 2)$ & $<1$ & a $(0 / 2)$ \\
\hline
\end{tabular}
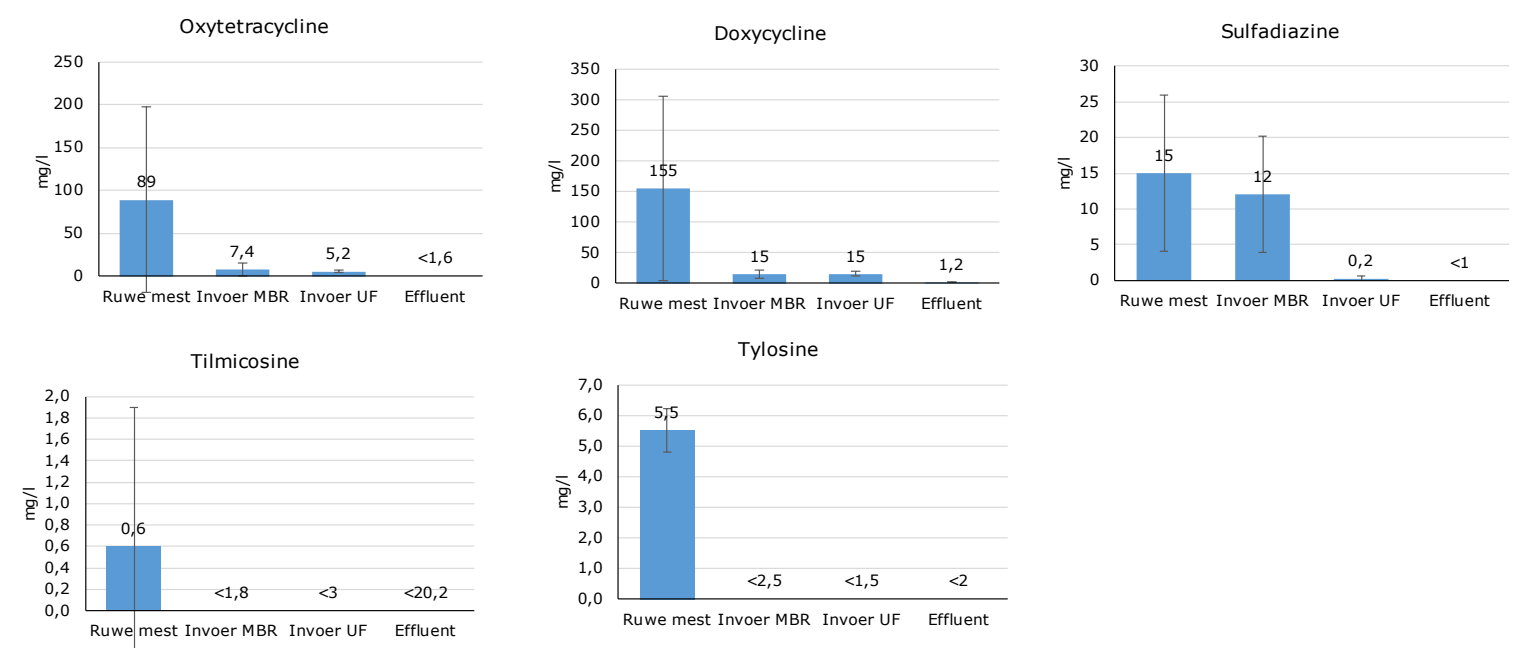

Figuur 3.15 Concentraties van antibiotica die werden aangetroffen in processtromen van de MBR-UF installatie. Alleen parameters met ten minste één reële meetwaarde zijn in de figuur weergegeven.

Van de aangetoonde antibiotica en hormoonstoffen in de ruwe mest wordt in de eerste scheidingsstap met een zeefbandpers een groot deel verwijderd. Dit deel komt in de vaste fractie terecht. De rest wordt door ultrafiltratie uitgefilterd; in het effluent zijn geen antibiotica aangetroffen. 
Tabel 18 Gemiddelde concentraties van micro-organismen in processtromen van de MBR-UF-installaties. Tussen haakjes staat het aantal positieve waarnemingen en het totale aantal waarnemingen. Voor berekening van de gemiddelde concentratie is voor monsters met waarnemingen onder de detectielimiet deze limiet aangenomen. De eenheid is de decadische logaritme van de concentratie in $\mathrm{KVE} / \mathrm{g}(\log 10(\mathrm{KVE} / \mathrm{g})$. Betekenis van de letters in superscript: verschillende letters per regel betekent dat het verschil in concentratie in vergelijking met de ruwe mest significant is $(p<0,05)$

\begin{tabular}{|c|c|c|c|c|c|c|c|c|c|c|c|c|c|c|c|c|}
\hline \multirow[b]{2}{*}{ E. coli } & \multicolumn{4}{|c|}{ Ruwe mest } & \multicolumn{4}{|c|}{ Invoer MBR } & \multicolumn{4}{|c|}{ Invoer UF } & \multicolumn{4}{|c|}{ Effluent } \\
\hline & 4,07 & 0,03 & a & $(3 / 3)$ & 3,56 & 0,07 & b & $(3 / 3)$ & 2,04 & 0,12 & $\mathrm{~b}$ & $(3 / 3)$ & $-1,36$ & 0,27 & $\mathrm{~b}$ & $(3 / 3)$ \\
\hline Enterokokken & 4,33 & 0,19 & a & $(3 / 3)$ & 3,46 & 0,21 & b & $(3 / 3)$ & 2,86 & 0,07 & $\mathrm{~b}$ & $(3 / 3)$ & $-0,84$ & 0,36 & b & $(3 / 3)$ \\
\hline $\begin{array}{l}\text { Sporen van } \\
\text { sulfietreducerende } \\
\text { Clostridia }\end{array}$ & 5,00 & 0,12 & a & $(3 / 3)$ & 3,39 & 0,10 & b & $(3 / 3)$ & 3,72 & 0,23 & $\mathrm{~b}$ & $(3 / 3)$ & $-0,02$ & 0,15 & $\mathrm{~b}$ & $(3 / 3)$ \\
\hline $\begin{array}{l}\text { Sporen van } C \text {. } \\
\text { difficile }\end{array}$ & 1,49 & 0,29 & a & $(3 / 3)$ & 0,88 & 0,54 & $\mathrm{a}$ & $(3 / 3)$ & 0,73 & 0,15 & $\mathrm{a}$ & $(2 / 3)$ & $-2,07$ & 0,33 & $\mathrm{~b}$ & $(3 / 3)$ \\
\hline ESBL E. coli & 1,29 & 0,33 & a & $(1 / 3)$ & 0,40 & 0,20 & $\mathrm{~b}$ & $(2 / 3)$ & $-0,05$ & 0 & $\mathrm{~b}$ & $(1 / 3)$ & $-2,48$ & & & $(0 / 3)$ \\
\hline Bacteriofagen & 4,69 & 0,08 & a & $(2 / 2)$ & 4,89 & 0,06 & a & $(2 / 2)$ & 3,92 & 0,22 & $\mathrm{~b}$ & $(2 / 2)$ & 0,08 & 0,12 & b & $(3 / 3)$ \\
\hline Campylobacter & Aanwezig & & & $(1 / 1)$ & Aanwezig & & & $(2 / 2)$ & Afwezig & & & $(0 / 1)$ & Afwezig & & & $(0 / 1)$ \\
\hline MRSA & Afwezig & & & $(0 / 2)$ & Afwezig & & & $(0 / 2)$ & Afwezig & & & $(0 / 2)$ & Afwezig & & & $(0 / 1)$ \\
\hline Hepatitis E virus & Aanwezig & & & $(1 / 2)$ & Afwezig & & & $(0 / 2)$ & Afwezig & & & $(0 / 2)$ & Afwezig & & & $(0 / 2)$ \\
\hline
\end{tabular}

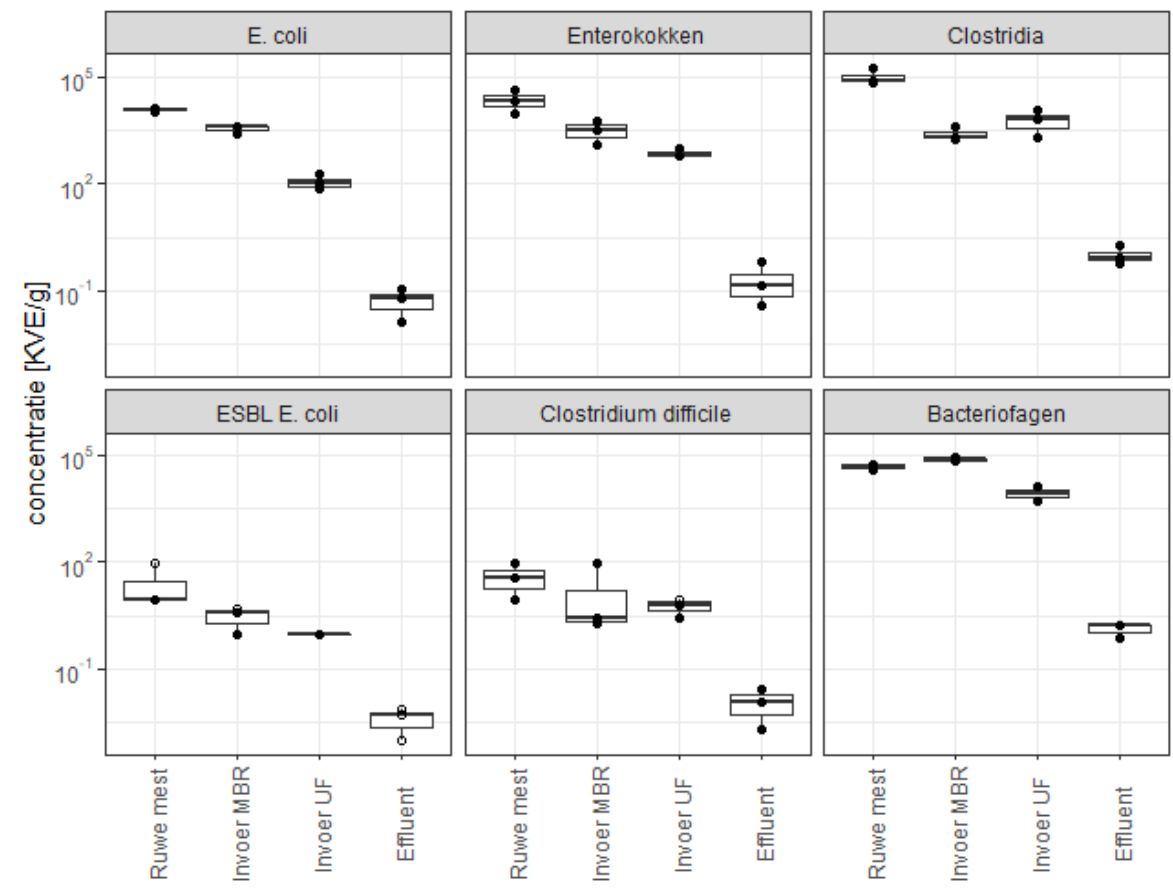

Figuur 3.16 Concentraties en hun variatie (mediaan als horizontale lijn, 25-75 percentiel als box, uitschieters als punten met een verticale verbinding naar de box) van micro-organismen in processtromen van de MBR-UF-installaties. Waarden onder de detectielimiet zijn vervangen door de detectielimiet en met open symbolen aangeduid, waarden boven de detectielimiet zijn door gevulde symbolen aangeduid.

Tabel 18 en Figuur 3.16 tonen dat bij elke behandelingsstap een afname plaatsvindt van de concentraties pathogenen, maar de UF-filtratiestap is bepalend voor het bereiken van de lage concentraties in het effluent.

De verwijdering van bacteriën en virussen is bij MBR-UF minder effectief dan bij OO. 


\subsection{Samenstelling van processtromen Biologische voorzuivering van kalvergier}

Tabel 19 Gemiddelde gehalten van algemene chemische parameters in processtromen van de installaties van biologische voorzuivering van kalvergier. Betekenis van de letters in superscript: verschillende letters per regel betekent dat het verschil in gehalte tussen processtromen significant is $(P<0.05)$. Tussen haakjes staat het aantal waarnemingen $>$ detectiegrens en het totale aantal waarnemingen.

\begin{tabular}{|c|c|c|c|c|c|c|c|}
\hline \multirow[t]{2}{*}{ Parameter } & \multirow{2}{*}{$\begin{array}{l}\text { Eenheid } \\
\text { mg/l }\end{array}$} & \multicolumn{2}{|c|}{ Ruwe mest } & \multicolumn{2}{|c|}{ Invoer Biologie } & \multicolumn{2}{|r|}{ Effluent } \\
\hline & & 12100 & a $(5 / 5)$ & 9792 & a $(9 / 9)$ & 1737 & b $(9 / 9)$ \\
\hline CZV & $\mathrm{mg} / \mathrm{l}$ & 63080 & a $(5 / 5)$ & 25664 & b $(9 / 9)$ & 5299 & c $(9 / 9)$ \\
\hline Onopgeloste stoffen & $\mathrm{mg} / \mathrm{l}$ & NA & $(0 / 0)$ & 1350 & a $(2 / 2)$ & 1311 & a $(9 / 9)$ \\
\hline P-totaal & $\mathrm{mg} / \mathrm{kg}$ & 527 & a $(7 / 7)$ & 194 & b $\quad(9 / 9)$ & 31 & c $(9 / 9)$ \\
\hline $\mathrm{P}-\mathrm{PO}_{4}$ & $\mathrm{mg} / \mathrm{kg}$ & 97 & a $(7 / 7)$ & 73 & b $\quad(9 / 9)$ & 19 & c $(9 / 9)$ \\
\hline $\mathrm{N}$-totaal & $\mathrm{mg} / \mathrm{kg}$ & 3978 & a $(7 / 7)$ & 3330 & b $\quad(9 / 9)$ & 168 & c $(9 / 9)$ \\
\hline $\mathrm{N}-\mathrm{NH}_{4}$ & $\mathrm{mg} / \mathrm{kg}$ & 2431 & a $(7 / 7)$ & 2231 & a $(9 / 9)$ & 48 & b $(9 / 9)$ \\
\hline $\mathrm{NO} 2-\mathrm{N}+\mathrm{NO}_{3}-\mathrm{N}$ & $\mathrm{mg} / \mathrm{kg}$ & 5,0 & a $(7 / 7)$ & 4,7 & a $(9 / 9)$ & 28 & a $(9 / 9)$ \\
\hline $\mathrm{pH}$ & - & 7,5 & a $(7 / 7)$ & 7,7 & b $\quad(9 / 9)$ & 8,3 & c $(9 / 9)$ \\
\hline EC & $\mathrm{mS} / \mathrm{cm}$ & 28 & a $(7 / 7)$ & 27 & a $(9 / 9)$ & 14 & b $(9 / 9)$ \\
\hline $\mathrm{Cl}-$ & $\mathrm{mg} / \mathrm{kg}$ & 2294 & a $(7 / 7)$ & 2050 & b $\quad(9 / 9)$ & 2133 & b $(9 / 9)$ \\
\hline $\mathrm{S}$ & $\mathrm{mg} / \mathrm{kg}$ & 330 & a $(7 / 7)$ & 262 & b $(9 / 9)$ & 200 & b $(9 / 9)$ \\
\hline $\mathrm{K}$ & $\mathrm{mg} / \mathrm{kg}$ & 3075 & a $(7 / 7)$ & 3256 & a $(9 / 9)$ & 3233 & a $(9 / 9)$ \\
\hline
\end{tabular}



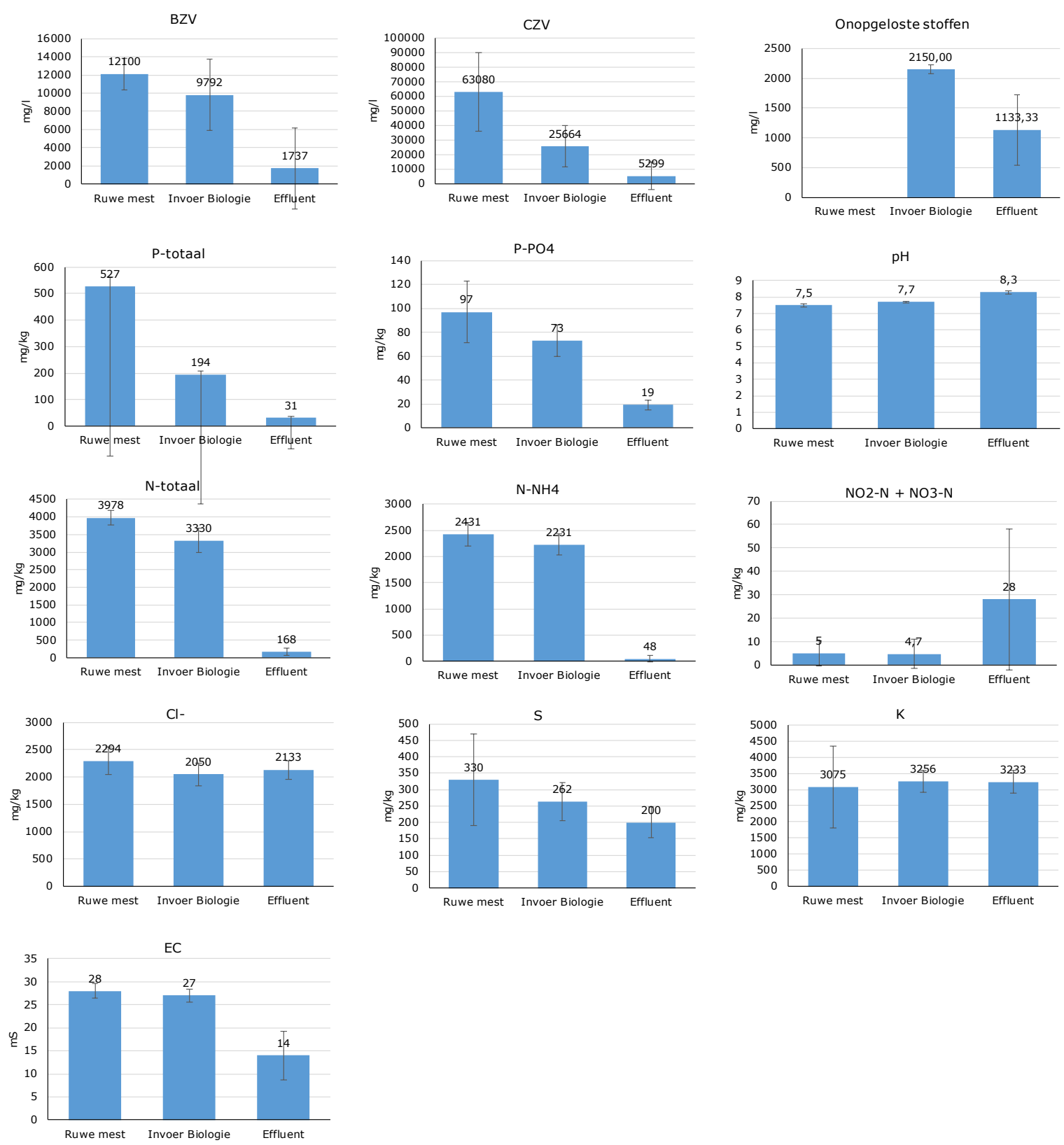

Figur 3.17 Gemiddelde concentraties en variaties (plus en min 1 x standaarddeviatie) van algemene chemische parameters in processtromen van installaties voor biologische voorzuivering.

Tabel 19 en Figuur 3.17 laten zien dat biologische voorzuivering van kalvergier effectief is voor verwijdering van BZV, CZV, P-totaal, $\mathrm{N}$-totaal, $\mathrm{N}-\mathrm{NH}_{4}$, maar niet of minder voor de verwijdering van de andere (opgeloste) componenten. Het effluent vertoont nog relatief hoge concentraties aan algemene chemische parameters waardoor het niet geschikt is om geloosd te worden op het oppervlaktewater. De 4 kalvergierbewerkingsinstallaties die nu operationeel zijn, voeren het effluent af naar een RWZI. 
Tabel 20 Gemiddelde concentraties van zware metalen in processtromen van de installaties voor biologische voorzuivering van kalvergier. Betekenis van de letters in superscript: verschillende letters per regel betekent dat het verschil in concentratie tussen processtromen significant is $(P<0,05)$. Tussen haakjes staat het aantal waarnemingen $>$ detectiegrens en het totale aantal waarnemingen.

\begin{tabular}{|c|c|c|c|c|c|c|c|c|c|}
\hline \multirow{2}{*}{$\begin{array}{l}\text { Parameter } \\
\text { Cd }\end{array}$} & \multirow{2}{*}{$\begin{array}{l}\text { Eenheid } \\
\text { mg/kg }\end{array}$} & \multicolumn{2}{|c|}{ Ruwe mest } & \multicolumn{3}{|c|}{ Invoer Biologie } & \multicolumn{3}{|c|}{ Effluent } \\
\hline & & $<0,03$ & a $\quad(0 / 4)$ & $<0,03$ & a & $(0 / 6)$ & $<0,03$ & a & $(0 / 6)$ \\
\hline $\mathrm{Hg}$ & $\mathrm{mg} / \mathrm{kg}$ & $<0,01$ & a $\quad(0 / 4)$ & $<0,01$ & a & $(0 / 6)$ & $<0,01$ & a & $(0 / 6)$ \\
\hline $\mathrm{Pb}$ & $\mathrm{mg} / \mathrm{kg}$ & 0,02 & a $\quad(3 / 4)$ & 0,01 & a & $(3 / 6)$ & $<0,01$ & a & $(0 / 6)$ \\
\hline As & $\mathrm{mg} / \mathrm{kg}$ & $<0,11$ & a $\quad(0 / 4)$ & $<0,11$ & a & $(0 / 6)$ & $<0,11$ & a & $(0 / 6)$ \\
\hline $\mathrm{Cr}$ & $\mathrm{mg} / \mathrm{kg}$ & 0,05 & a $\quad(2 / 4)$ & 0,01 & a & $(1 / 6)$ & $<0,07$ & a & $(0 / 6)$ \\
\hline $\mathrm{Ni}$ & $\mathrm{mg} / \mathrm{kg}$ & 0,11 & a $\quad(3 / 4)$ & 0,10 & a & $(5 / 6)$ & 0,02 & b & $(1 / 6)$ \\
\hline $\mathrm{Cu}$ & $\mathrm{mg} / \mathrm{kg}$ & 2,2 & a $\quad(3 / 4)$ & 1,9 & a & $(5 / 6)$ & 0,30 & b & $(1 / 6)$ \\
\hline $\mathrm{Zn}$ & $\mathrm{mg} / \mathrm{kg}$ & 24 & a $\quad(4 / 4)$ & 20 & a & $(5 / 6)$ & 4,0 & b & $(3 / 6)$ \\
\hline $\mathrm{Ba}$ & $\mathrm{mg} / \mathrm{kg}$ & 0,47 & a $(3 / 4)$ & 0,30 & a & $(5 / 6)$ & 0,05 & b & $(1 / 6)$ \\
\hline V & $\mathrm{mg} / \mathrm{kg}$ & $<0,28$ & a $\quad(0 / 4)$ & $<0,28$ & a & $(0 / 6)$ & $<0,28$ & a & $(0 / 6)$ \\
\hline U & $\mathrm{mg} / \mathrm{kg}$ & $<0,06$ & a $\quad(0 / 4)$ & $<0,06$ & a & $(0 / 6)$ & $<0,06$ & a & $(0 / 6)$ \\
\hline Co & $\mathrm{mg} / \mathrm{kg}$ & NA & $(0 / 0)$ & NA & & $(0 / 0)$ & NA & & $(0 / 0)$ \\
\hline Se & $\mathrm{mg} / \mathrm{kg}$ & NA & $(0 / 0)$ & NA & & $(0 / 0)$ & NA & & $(0 / 0)$ \\
\hline
\end{tabular}



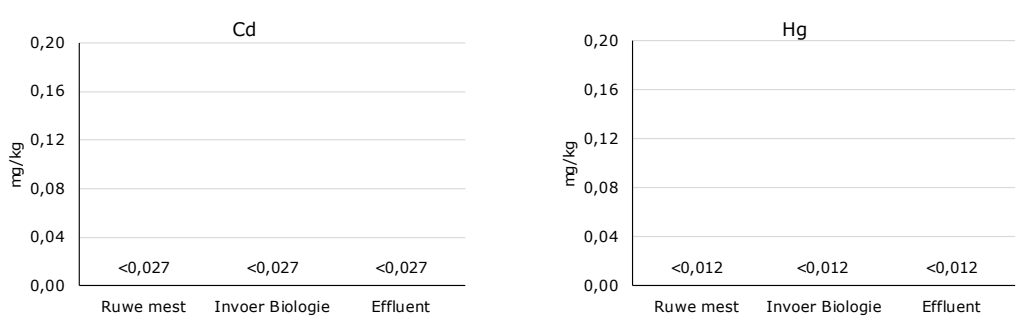

$\mathrm{Pb}$

As

$\mathrm{Cr}$

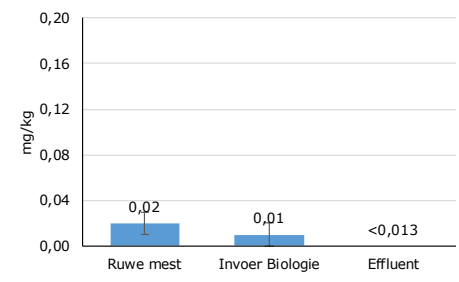

$\mathrm{Ni}$
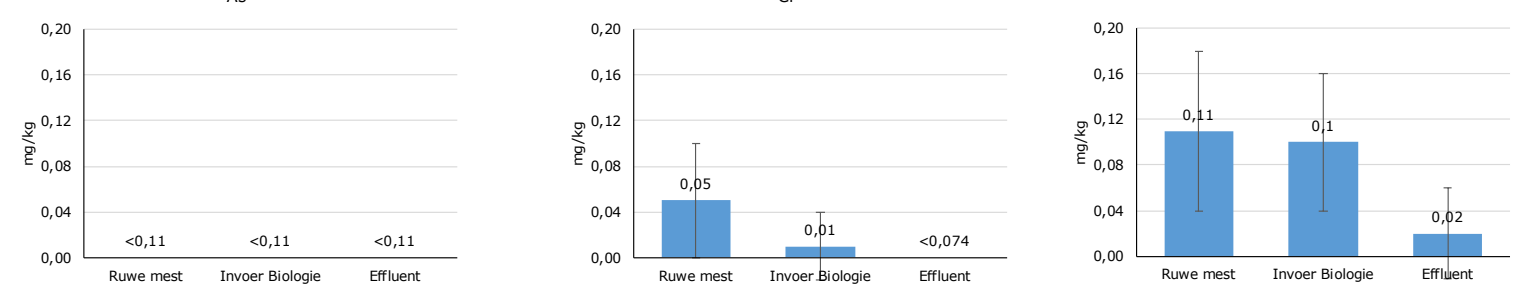

$\mathrm{Cu}$

$\mathrm{Zn}$
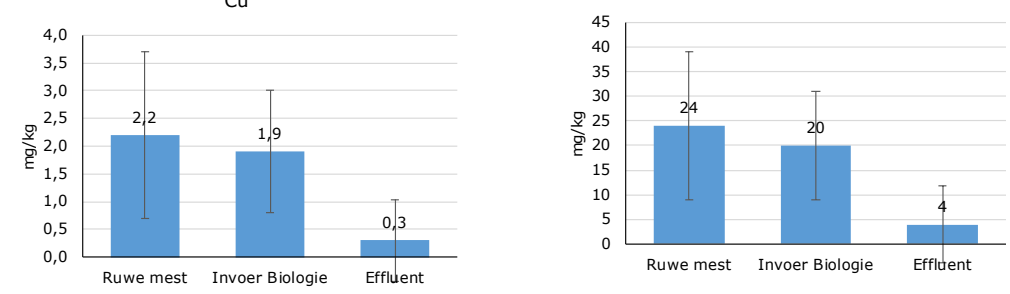

$\mathrm{Ba}$
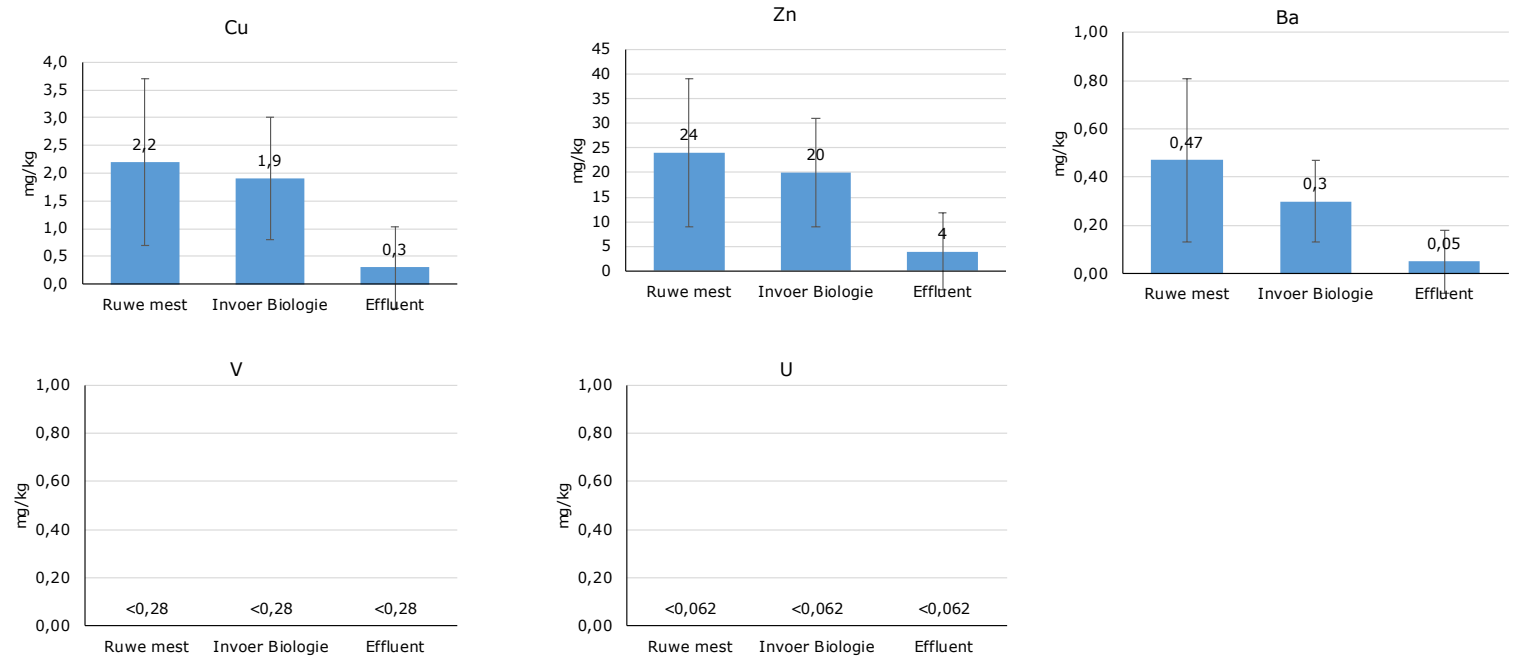

Figuur 3.18 Gemiddelde concentraties en variaties (plus en min 1 x standaarddeviatie) van zware metalen die werden aangetroffen in processtromen van de installaties voor biologische voorzuivering.

Uit Tabel 20 en Figuur 3.18 blijkt dat scheiding van kalvergier met een decanteercentrifuge niet effectief is voor de verwijdering van zware metalen; de gehalten in de invoer biologie verschillen niet significant van die in de ruwe mest. Bezinking heeft wel duidelijk effect op zware metalen gezien het feit dat ze, met uitzondering van zink, niet meer aantoonbaar zijn in het effluent. Dit duidt erop dat ze in het slib achterblijven.

Op basis van deze observaties zou zink als indicator voor zware metalen in het effluent van biologische voorzuivering van kalvergier aangemerkt kunnen worden. 
Gemiddelde concentraties van hormoonstoffen en antibiotica in processtromen van de installaties voor biologische voorzuivering van kalvergier. Waarden boven de detectiegrens zijn vetgedrukt. Betekenis van de letters in superscript: verschillende letters per regel betekent dat het verschil in concentratie tussen processtromen significant is $(P<0,05)$. Tussen haakjes staat het aantal waarnemingen > detectiegrens en het totale aantal waarnemingen.

\begin{tabular}{|c|c|c|c|c|c|c|c|}
\hline \multirow{2}{*}{$\begin{array}{c}\text { Parameter } \\
\text { Hormoonstoffen }\end{array}$} & \multirow[t]{2}{*}{ Eenheid } & \multicolumn{2}{|r|}{ Ruwe mest } & \multicolumn{2}{|c|}{ Invoer Biologie } & \multicolumn{2}{|r|}{ Effluent } \\
\hline & & & & & & & \\
\hline ER-CALUX & ng $17 B \mathrm{EEQ} / \mathrm{g}$ & 0,37 & $(4 / 4)$ & 0,16 & $(4 / 4)$ & 0,00118 & $(3 / 4)$ \\
\hline \multicolumn{8}{|l|}{ Antibiotica } \\
\hline Oxytetracycline & $\mu \mathrm{g} / \mathrm{kg}$ & 1954 & a $(13 / 13)$ & 1463 & a $(15 / 15)$ & 479 & b $\quad(15 / 15)$ \\
\hline Doxycycline & $\mu \mathrm{g} / \mathrm{kg}$ & 1379 & a $(13 / 13)$ & 1703 & a $(15 / 15)$ & 312 & b $\quad(15 / 15)$ \\
\hline Sulfadiazine & $\mu \mathrm{g} / \mathrm{kg}$ & 61 & a $(13 / 13)$ & 81 & a $(14 / 15)$ & 5,3 & $(5 / 15)$ \\
\hline Sulfadimidine & $\mu g / k g$ & 43 & a $(13 / 13)$ & 14 & ab $\quad(14 / 15)$ & 2,8 & $(2 / 15)$ \\
\hline Trimethoprim & $\mu \mathrm{g} / \mathrm{kg}$ & $<1,8$ & a $\quad(0 / 13)$ & $<1,8$ & a $\quad(0 / 15)$ & $<1,0$ & $(0 / 15)$ \\
\hline Ciprofloxacine & $\mu \mathrm{g} / \mathrm{kg}$ & 0,77 & a $\quad(4 / 13)$ & 0,33 & ab $\quad(3 / 15)$ & $<1,1$ & $(0 / 15)$ \\
\hline Enrofloxacine & $\mu g / k g$ & $<5,6$ & a $\quad(0 / 13)$ & $<5,2$ & a $\quad(0 / 15)$ & 0,13 & $(1 / 15)$ \\
\hline Flumequine & $\mu \mathrm{g} / \mathrm{kg}$ & 412 & a $(13 / 13)$ & 284 & ab $(15 / 15)$ & 195 & b $\quad(15 / 15)$ \\
\hline Lincomycine & $\mu \mathrm{g} / \mathrm{kg}$ & $<2,2$ & a $\quad(0 / 13)$ & $<2,2$ & a $\quad(0 / 15)$ & $<1,2$ & $(0 / 15)$ \\
\hline Tilmicosine & $\mu \mathrm{g} / \mathrm{kg}$ & 135 & a $(13 / 13)$ & 102 & b $\quad(15 / 15)$ & 15 & b $\quad(14 / 15)$ \\
\hline Florfenicol & $\mu g / k g$ & $<1,2$ & a $\quad(0 / 13)$ & $<1,1$ & a $\quad(0 / 15)$ & $<1,1$ & $(0 / 15)$ \\
\hline Chloortetracycline & $\mu \mathrm{g} / \mathrm{kg}$ & 24 & $(4 / 9)$ & 3,4 & b $\quad(2 / 10)$ & 1,4 & $(1 / 10)$ \\
\hline Tetracycline & $\mu \mathrm{g} / \mathrm{kg}$ & 16 & $(8 / 9)$ & 12 & ab $\quad(9 / 10)$ & 4,7 & $(2 / 10)$ \\
\hline Minocycline & $\mu g / k g$ & $<23$ & $(0 / 9)$ & $<20$ & a $\quad(0 / 10)$ & $<1,1$ & $(0 / 10)$ \\
\hline Methacycline & $\mu \mathrm{g} / \mathrm{kg}$ & $<10$ & $(0 / 9)$ & $<9,7$ & a $\quad(0 / 10)$ & $<4,2$ & $(0 / 10)$ \\
\hline Sulfathiazol & $\mu \mathrm{g} / \mathrm{kg}$ & $<3,2$ & $(0 / 9)$ & $<2,8$ & a $\quad(0 / 10)$ & $<1,8$ & $(0 / 10)$ \\
\hline Sulfapyridine & $\mu \mathrm{g} / \mathrm{kg}$ & $<2,3$ & $(0 / 9)$ & $<1,9$ & a $\quad(0 / 10)$ & $<1,1$ & $(0 / 10)$ \\
\hline Sulfamerazine & $\mu \mathrm{g} / \mathrm{kg}$ & $<1,0$ & $(0 / 9)$ & $<1,0$ & a $\quad(0 / 10)$ & $<1,0$ & a $\quad(0 / 10)$ \\
\hline Sulfamoxol & $\mu \mathrm{g} / \mathrm{kg}$ & $<1,1$ & $(0 / 9)$ & $<1,1$ & a $\quad(0 / 10)$ & $<1,0$ & $(0 / 10)$ \\
\hline Sulfamethizol & $\mu \mathrm{g} / \mathrm{kg}$ & $<1,2$ & $(0 / 9)$ & $<1,1$ & a $\quad(0 / 10)$ & $<1,1$ & $(0 / 10)$ \\
\hline Sulfamethoxypyridazine & $\mu \mathrm{g} / \mathrm{kg}$ & $<1,0$ & $(0 / 9)$ & $<1,0$ & a $\quad(0 / 10)$ & $<1,0$ & a $\quad(0 / 10)$ \\
\hline Sulfamonomethoxine & $\mu \mathrm{g} / \mathrm{kg}$ & $<1,2$ & $(0 / 9)$ & $<1,2$ & a $\quad(0 / 10)$ & $<1,1$ & a $\quad(0 / 10)$ \\
\hline Sulfachloorpyridazine & $\mu \mathrm{g} / \mathrm{kg}$ & $<2,3$ & $(0 / 9)$ & $<1,7$ & a $\quad(0 / 10)$ & $<1,3$ & $(0 / 10)$ \\
\hline Sulfadoxine & $\mu \mathrm{g} / \mathrm{kg}$ & $<1,0$ & $(0 / 9)$ & $<1,0$ & a $\quad(0 / 10)$ & $<1,0$ & a $\quad(0 / 10)$ \\
\hline Sulfamethoxazol & $\mu g / k g$ & $<1,3$ & $(0 / 9)$ & 0,20 & b $\quad(1 / 10)$ & $<1,1$ & a $\quad(0 / 10)$ \\
\hline Sulfisoxazol & $\mu \mathrm{g} / \mathrm{kg}$ & $<1,7$ & $(0 / 9)$ & $<1,6$ & a $\quad(0 / 10)$ & $<1,1$ & a $\quad(0 / 10)$ \\
\hline Sulfadimethoxine & $\mu \mathrm{g} / \mathrm{kg}$ & $<1,2$ & $(0 / 9)$ & $<1,0$ & a $\quad(0 / 10)$ & $<1,0$ & a $\quad(0 / 10)$ \\
\hline Sulfaquinoxaline & $\mu \mathrm{g} / \mathrm{kg}$ & $<1,4$ & $(0 / 9)$ & $<1,4$ & a $\quad(0 / 10)$ & $<1,1$ & $(0 / 10)$ \\
\hline Sulfacetamide & $\mu \mathrm{g} / \mathrm{kg}$ & $<1,0$ & $(0 / 9)$ & $<1,4$ & a $\quad(0 / 10)$ & $<1,0$ & a $\quad(0 / 10)$ \\
\hline Sulfaphenazol & $\mu \mathrm{g} / \mathrm{kg}$ & $<10$ & $(0 / 9)$ & $<8,5$ & a $\quad(0 / 10)$ & $<3,9$ & a $\quad(0 / 10)$ \\
\hline Dapson & $\mu g / k g$ & $<1,0$ & $(0 / 9)$ & $<1,1$ & ${ }^{a} \quad(0 / 10)$ & $<1,0$ & $(0 / 10)$ \\
\hline Marbofloxacine & $\mu \mathrm{g} / \mathrm{kg}$ & 1,0 & $(2 / 9)$ & $<3,6$ & b $\quad(0 / 10)$ & 0,40 & a $\quad(2 / 10)$ \\
\hline Norfloxacine & $\mu \mathrm{g} / \mathrm{kg}$ & $<12$ & $(0 / 9)$ & $<8,6$ & a $\quad(0 / 10)$ & $<3,8$ & $(0 / 10)$ \\
\hline Danofloxacine & $\mu \mathrm{g} / \mathrm{kg}$ & $<8,8$ & $(0 / 9)$ & $<8,0$ & ${ }^{a} \quad(0 / 10)$ & $<2,0$ & $(0 / 10)$ \\
\hline Sarafloxacine & $\mu \mathrm{g} / \mathrm{kg}$ & $<12$ & $(0 / 9)$ & $<12$ & a $\quad(0 / 10)$ & $<6,3$ & a $\quad(0 / 10)$ \\
\hline Difloxacine & $\mu \mathrm{g} / \mathrm{kg}$ & $<5,3$ & $(0 / 9)$ & $<4,0$ & a $\quad(0 / 10)$ & $<1,9$ & $(0 / 10)$ \\
\hline Oxolinezuur & $\mu \mathrm{g} / \mathrm{kg}$ & $<3,9$ & $(0 / 9)$ & $<3,6$ & a $\quad(0 / 10)$ & $<1,5$ & $(0 / 10)$ \\
\hline Nalidixinezuur & $\mu \mathrm{g} / \mathrm{kg}$ & $<3,8$ & $(0 / 9)$ & $<3,0$ & a $\quad(0 / 10)$ & $<1,2$ & a $\quad(0 / 10)$ \\
\hline Levofloxacin/ofloxacin & $\mu \mathrm{g} / \mathrm{kg}$ & $<4,3$ & $(0 / 9)$ & $<3,9$ & a $\quad(0 / 10)$ & $<3,7$ & $(0 / 10)$ \\
\hline Trovafloxacin & $\mu \mathrm{g} / \mathrm{kg}$ & $<1,8$ & $(0 / 9)$ & $<1,6$ & a $\quad(0 / 10)$ & $<1,1$ & $(0 / 10)$ \\
\hline Erythromycine & $\mu \mathrm{g} / \mathrm{kg}$ & $<17$ & $(0 / 9)$ & $<14$ & a $\quad(0 / 10)$ & $<1,6$ & a $\quad(0 / 10)$ \\
\hline Tylosine & $\mu \mathrm{g} / \mathrm{kg}$ & $<23$ & $(0 / 9)$ & $<14$ & a $\quad(0 / 10)$ & $<11^{\circ}$ & $(0 / 10)$ \\
\hline Josamycine & $\mu \mathrm{g} / \mathrm{kg}$ & $<12$ & $(0 / 9)$ & $<5,7$ & a $\quad(0 / 10)$ & $<4,1$ & $(0 / 10)$ \\
\hline Spiramycine & $\mu g / k g$ & $<9,4$ & $(0 / 9)$ & $<6,7$ & a $\quad(0 / 10)$ & $<2,8$ & $(0 / 10)$ \\
\hline Neospiramycine 1 & $\mu \mathrm{g} / \mathrm{kg}$ & $<6,4$ & $(0 / 9)$ & $<6,7$ & a $\quad(0 / 10)$ & $<6,2$ & $(0 / 10)$ \\
\hline Tiamulin & $\mu \mathrm{g} / \mathrm{kg}$ & $<3,6$ & $(0 / 9)$ & $<3,2$ & a $\quad(0 / 10)$ & $<1,1$ & $(0 / 10)$ \\
\hline Tulathromycine & $\mu g / k g$ & 1,1 & $(6 / 9)$ & 1,1 & a $\quad(5 / 10)$ & 1,7 & $(2 / 10)$ \\
\hline Pirlimycine & $\mu \mathrm{g} / \mathrm{kg}$ & $<2,7$ & $(0 / 9)$ & $<2,2$ & a $\quad(0 / 10)$ & $<1,2$ & $(0 / 10)$ \\
\hline Valnemulin & $\mu \mathrm{g} / \mathrm{kg}$ & $<1,4$ & $(0 / 9)$ & $<1,4$ & b $\quad(0 / 10)$ & 0,20 & a $\quad(1 / 10)$ \\
\hline Tylvalosine & $\mu \mathrm{g} / \mathrm{kg}$ & $<2,8$ & $(0 / 9)$ & $<2,6$ & a $\quad(0 / 10)$ & $<2,1$ & a $\quad(0 / 10)$ \\
\hline
\end{tabular}




\begin{tabular}{|c|c|c|c|c|c|c|c|c|c|c|}
\hline Natamycin & $\mu \mathrm{g} / \mathrm{kg}$ & $<12$ & & $(0 / 9)$ & $<7,3$ & a & $(0 / 10)$ & $<3,4$ & a & $(0 / 10)$ \\
\hline Gamithromycine & $\mu \mathrm{g} / \mathrm{kg}$ & $<2,4$ & a & $(0 / 9)$ & $<2,1$ & a & $(0 / 10)$ & $<2,2$ & a & $(0 / 10)$ \\
\hline Tildipirosine & $\mu g / k g$ & $<1,0$ & a & $(0 / 9)$ & $<1,2$ & a & $(0 / 10)$ & $<4,2$ & a & $(0 / 10)$ \\
\hline Vancomycine & $\mu \mathrm{g} / \mathrm{kg}$ & $<18$ & a & $(0 / 9)$ & $<11$ & a & $(0 / 10)$ & $<4,5$ & a & $(0 / 10)$ \\
\hline Azithromycine & $\mu \mathrm{g} / \mathrm{kg}$ & $<1,3$ & a & $(0 / 9)$ & $<1,4$ & $\mathrm{a}$ & $(0 / 10)$ & $<1,0$ & a & $(0 / 10)$ \\
\hline Clarithromycine & $\mu \mathrm{g} / \mathrm{kg}$ & $<4,1$ & $\mathrm{a}$ & $(0 / 9)$ & $<2,5$ & $\mathrm{a}$ & $(0 / 10)$ & $<1,9$ & a & $(0 / 10)$ \\
\hline
\end{tabular}



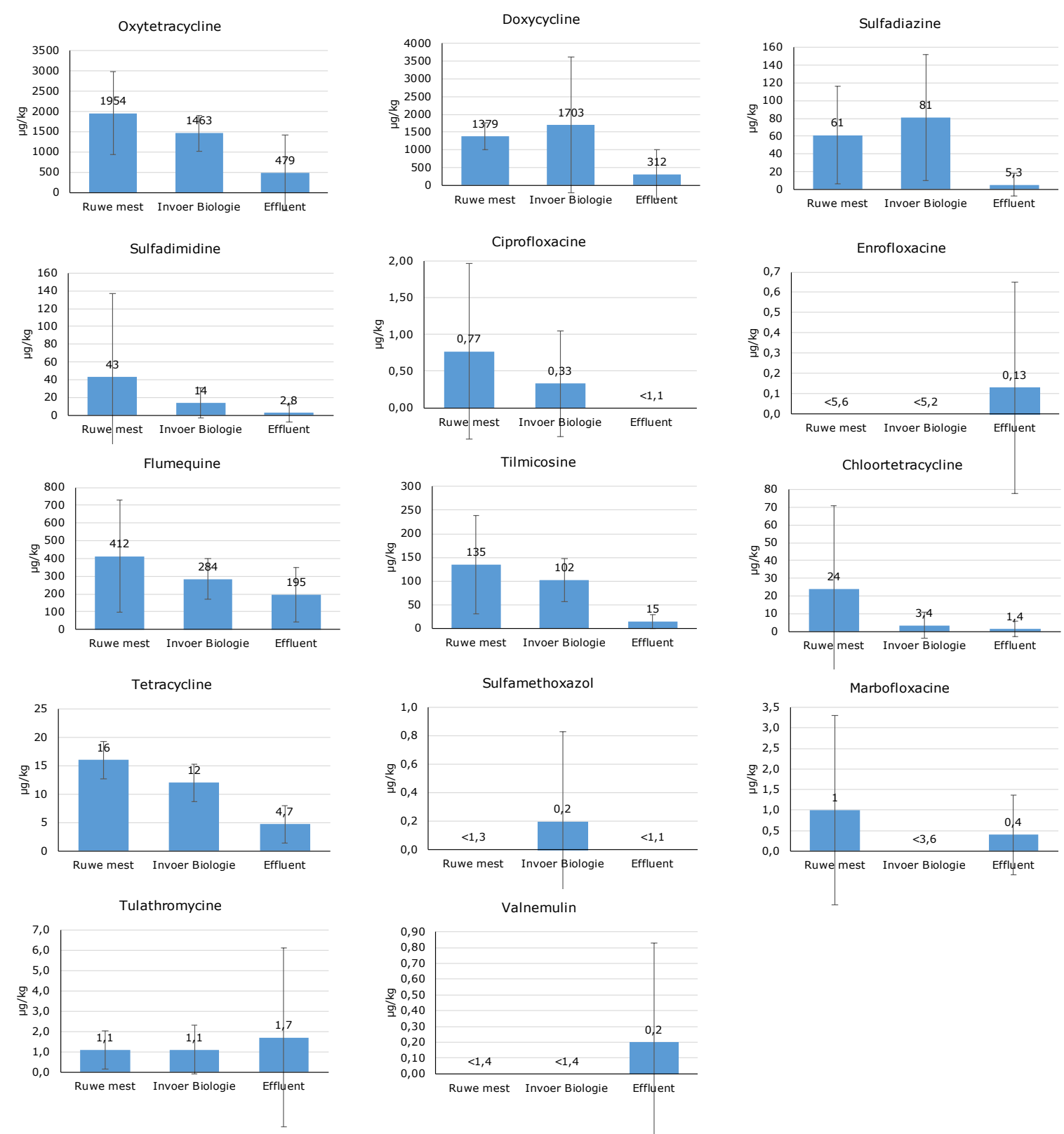

Figuur 3.19 Gemiddelde concentraties en variaties (plus en min 1 x standaarddeviatie) van antibiotica in processtromen van installaties voor biologische voorzuivering. Alleen de parameters met ten minste één reële meetwaarde zijn in de figuur weergegeven.

Tabel 21 en Figuur 3.19 laten zien dat scheiding van kalvergier middels een decanteercentrifuge slechts een gering effect heeft op antibiotica; verschillen tussen ruwe mest en invoer biologie zijn niet significant. Slibbezinking heeft een duidelijk reducerend effect wat resulteert in aanzienlijk lagere concentraties in het effluent. Mogelijk heeft ook biologische afbraak hieraan bijgedragen.

Oxytetracycline, doxycycline, flumequine en in mindere mate tilmicosine worden nog in vrij hoge concentraties in het effluent aangetroffen. De concentraties van oxytetracycline en doxycycline liggen boven de PNEC-waarde.

Ook hormoonstoffen zijn in aantoonbare concentraties in het effluent van biologische voorzuivering aanwezig. 
Tabel 22 Gemiddelde concentraties van micro-organismen in processtromen van biologische voorzuivering van kalvergier. Tussen haakjes staat het aantal positieve waarnemingen en het totale aantal waarnemingen. Voor berekening van de gemiddelde concentratie is voor monsters met waarnemingen onder de limiet van detectie het limiet van detectie aangenomen. De eenheid is de decadische logaritme van de concentratie in KVE/g (log10(KVE/g). Betekenis van de letters in superscript: verschillende letters per regel betekent dat het verschil in concentratie in vergelijking met de ruwe mest significant is $(p<0,05)$.

\begin{tabular}{|c|c|c|c|c|c|c|c|c|c|c|}
\hline \multirow[b]{2}{*}{ E. coli } & \multicolumn{3}{|c|}{ Ruwe mest } & \multicolumn{4}{|c|}{ Invoer biologie } & \multicolumn{3}{|c|}{ Effluent } \\
\hline & 4,79 & 0,21 & a $(4 / 4)$ & 4,72 & 0,08 & a & $(8 / 8)$ & 2,22 & 0,20 & b $\quad(7 / 8)$ \\
\hline Enterokokken & 6,54 & 0,31 & a $(4 / 4)$ & 5,77 & 0,40 & a & $(8 / 8)$ & 2,91 & 0,56 & b $\quad(6 / 8)$ \\
\hline $\begin{array}{l}\text { Sporen van } \\
\text { sulfietreducerende } \\
\text { Clostridia }\end{array}$ & 4,20 & 0,18 & a $(4 / 4)$ & 4,13 & 0,15 & a & $(8 / 8)$ & 3,24 & 0,13 & b $\quad(8 / 8)$ \\
\hline Sporen van C. difficile & 1,48 & 0,16 & a $(4 / 4)$ & 1,51 & 0,15 & 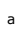 & $(7 / 8)$ & 0,84 & 0,26 & b $\quad(7 / 8)$ \\
\hline ESBL E. coli & 2,31 & 0,09 & a $(4 / 4)$ & 2,63 & 0,10 & a & $(8 / 8)$ & 0,20 & 0,15 & a $\quad(7 / 8)$ \\
\hline Bacteriofagen & NA & & & NA & & & & NA & & \\
\hline Campylobacter & Afwezig & & $(0 / 4)$ & Afwezig & & & $(0 / 4)$ & Aanwezig & & $(2 / 4)$ \\
\hline MRSA & Aanwezig & & $(1 / 4)$ & Aanwezig & & & $(3 / 7)$ & Afwezig & & $(0 / 7)$ \\
\hline
\end{tabular}

Hepatitis E virus NA NA NA

NA niet onderzocht
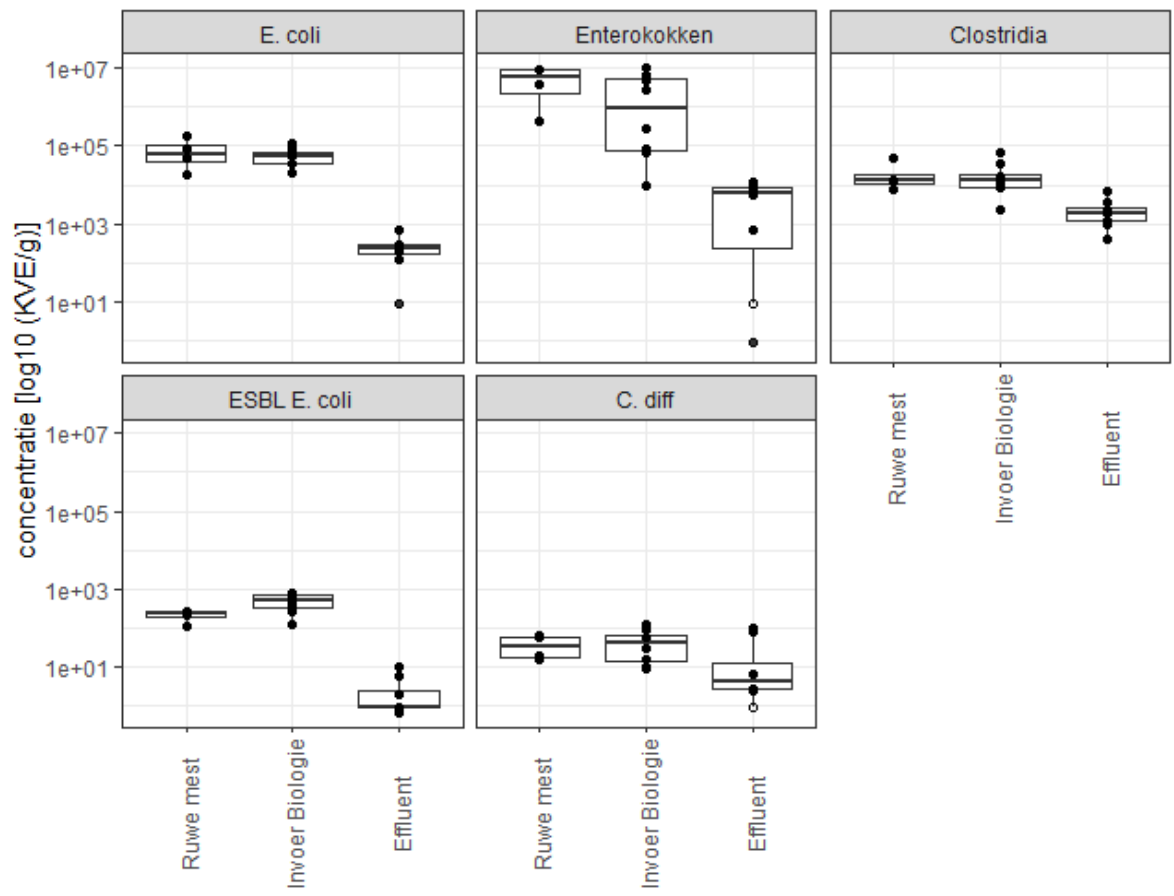

Figuur 3.20 Concentraties en hun variatie (mediaan als horizontale lijn, 25-75 percentiel als box, uitschieters als punten met een verticale verbinding naar de box) van micro-organismen in de ruwe mest in processtromen van de biologische installaties. Waarden onder de detectielimiet zijn vervangen door de detectielimiet en met open symbolen aangeduid, waarden boven de detectielimiet zijn door gevulde symbolen aangeduid. micro-organismen.

Tabel 22 en Figuur 3.20 tonen dat scheiding van kalvergier met een decanteercentrifuge niet leidt tot wezenlijke veranderingen in de concentraties van bacteriën. De biologische zuivering en slibbezinking leidt tot reductie met een factor van ca. $\log 2-\log 3$ van $E$. coli en enterokokken. De verwijdering van sporen van Clostridia blijft hierbij beduidend achter. Ter vergelijking, Schmitt et al (2017) vonden in het effluent van 100 RWZI's een vergelijkbare reductie van resistente en niet-resistente $E$. coli van log 2 tot 3 ten opzichte van het influent. 


\subsection{Samenstelling van processtromen Indampen}

Tabel 23 Gemiddelde gehalten van de algemene chemische parameters in processtromen van de indampinstallatie. Betekenis van de letters in superscript: verschillende letters per regel betekent dat het verschil in gehalte tussen processtromen significant is $(P<0,05)$. Tussen haakjes staat het aantal waarnemingen > detectiegrens en het totale aantal waarnemingen.

\begin{tabular}{|c|c|c|c|c|c|c|c|c|c|}
\hline Parameter & Eenheid & & Higestaat & Invoer & indamper & & fluent-1* & Efflu & ient- $2 * *$ \\
\hline BZV & $\mathrm{mg} / \mathrm{l}$ & NA & a $(0 / 0)$ & 8034 & b $\quad(5 / 5)$ & 20 & a $(2 / 2)$ & 35 & a $(3 / 3)$ \\
\hline $\mathrm{CZV}$ & $\mathrm{mg} / \mathrm{l}$ & NA & a $(0 / 0)$ & 32100 & b $\quad(5 / 5)$ & 37 & a $(2 / 2)$ & 92 & a $(3 / 3)$ \\
\hline Onopgeloste stoffen & $\mathrm{mg} / \mathrm{l}$ & NA & $(0 / 0)$ & NA & $(0 / 0)$ & $<5,0$ & a $(0 / 2)$ & $<6,3$ & a $(0 / 3)$ \\
\hline P-totaal & $\mathrm{mg} / \mathrm{kg}$ & 2637 & a $(2 / 2)$ & 464 & b $\quad(4 / 4)$ & 6,3 & c $(2 / 2)$ & 1,1 & c $(2 / 2)$ \\
\hline $\mathrm{P}-\mathrm{PO}_{4}$ & $\mathrm{mg} / \mathrm{kg}$ & 553 & a $(2 / 2)$ & 350 & b $\quad(4 / 4)$ & 0,12 & c $(2 / 2)$ & 2,1 & c $(2 / 2)$ \\
\hline $\mathrm{N}$-totaal & $\mathrm{mg} / \mathrm{kg}$ & 8599 & a $(2 / 2)$ & 6112 & b $\quad(4 / 4)$ & 53 & c $(2 / 2)$ & 3,3 & c $(2 / 2)$ \\
\hline $\mathrm{N}-\mathrm{NH}_{4}$ & $\mathrm{mg} / \mathrm{kg}$ & 4711 & a $(2 / 2)$ & 4568 & a $(4 / 4)$ & 43 & b $\quad(2 / 2)$ & 6,4 & b $\quad(2 / 2)$ \\
\hline $\mathrm{NO}_{2}-\mathrm{N}+\mathrm{NO}_{3}-\mathrm{N}$ & $\mathrm{mg} / \mathrm{kg}$ & 9,6 & a $(2 / 2)$ & 5,1 & b $\quad(4 / 4)$ & 0,54 & c $(2 / 2)$ & 8,6 & a $(2 / 2)$ \\
\hline $\mathrm{pH}$ & - & 8,1 & a $(2 / 2)$ & 8,6 & a $(4 / 4)$ & 8,2 & a $(2 / 2)$ & 6,0 & a $\quad(2 / 2)$ \\
\hline EC & $\mathrm{mS} / \mathrm{cm}$ & 31 & a $\quad(2 / 2)$ & 38 & b $\quad(4 / 4)$ & 0,09 & c $(2 / 2)$ & 0,07 & c $(2 / 2)$ \\
\hline $\mathrm{Cl}-$ & $\mathrm{mg} / \mathrm{kg}$ & 1903 & a $(2 / 2)$ & 2333 & b $\quad(5 / 5)$ & 0 & c $(2 / 2)$ & 0 & c $(2 / 2)$ \\
\hline $\mathrm{s}$ & $\mathrm{mg} / \mathrm{kg}$ & 885 & a $(2 / 2)$ & 840 & a $\quad(4 / 4)$ & 0 & b $\quad(2 / 2)$ & 5,0 & b $\quad(2 / 2)$ \\
\hline K & $\mathrm{mg} / \mathrm{kg}$ & 4400 & a $\quad(2 / 2)$ & 4325 & a $(4 / 4)$ & 0 & b $\quad(2 / 2)$ & 0 & b $\quad(2 / 2)$ \\
\hline
\end{tabular}



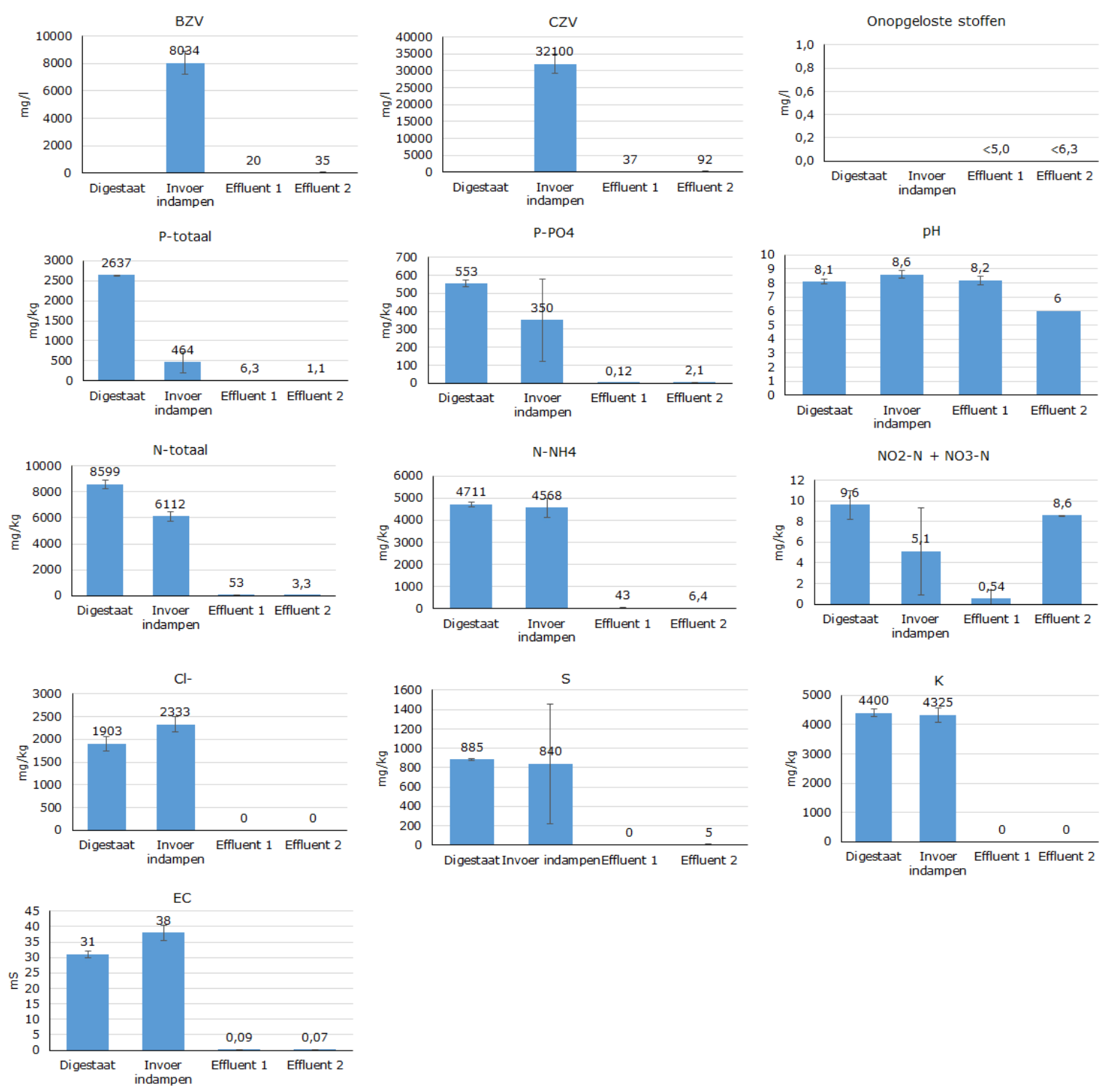

Figuur 3.21 Gemiddelde concentraties en variaties (plus en min 1 x standaarddeviatie) van algemene chemische parameters in processtromen van de indampinstallatie. Indampen-1 is gemeten vóór, indampen-2 ná OO en IW.

Tabel 23 en Figuur 3.21 laten zien dat mechanische scheiding (zeefbandpers) van digestaat resulteert in sterk gereduceerde gehalten van $\mathrm{P}$-totaal en $\mathrm{P}_{-} \mathrm{PO}_{4}$ in de invoer van de indamper, maar het effect op de andere algemene parameters blijkt gering. In het effluent van de indamper werden de meeste parameters in lage gehalten aangetroffen. In effluent-1, vóór $\mathrm{OO}$ en IW, zijn de concentraties van Ntotaal en $\mathrm{N}-\mathrm{NH}_{4}$ nog aanzienlijk. Ná OO en IW vindt een substantiële afname van deze componenten plaats. BZV en CZV laten geen afname zien. 
Tabel 24 Gemiddelde concentraties van zware metalen in processtromen van de indampinstallatie.

Betekenis van de letters in superscript: verschillende letters per regel betekent dat het verschil in concentratie tussen processtromen significant is $(P<0,05)$. Tussen haakjes staat het aantal waarnemingen $>$ detectiegrens en het totale aantal waarnemingen.

\begin{tabular}{|c|c|c|c|c|c|c|c|c|c|c|c|c|c|}
\hline Parameter & Eenheid & & Dig & estaat & Invoer & inc & amper & & flu & nt-1* & & ue & $\mathrm{t}-2 * *$ \\
\hline $\mathrm{Cd}$ & $\mathrm{mg} / \mathrm{kg}$ & 0,03 & $\mathrm{~b}$ & $(1 / 1)$ & $<0,027$ & a & $(0 / 3)$ & $<0,03$ & a & $(0 / 3)$ & $<0,03$ & a & $(0 / 1)$ \\
\hline $\mathrm{Hg}$ & $\mathrm{mg} / \mathrm{kg}$ & $<0,012$ & a & $(0 / 1)$ & $<0,012$ & a & $(0 / 3)$ & 0,02 & a & $(1 / 3)$ & $<0,01$ & A & $(0 / 1)$ \\
\hline $\mathrm{Pb}$ & $\mathrm{mg} / \mathrm{kg}$ & 0,18 & a & $(1 / 1)$ & $<0,013$ & a & $(0 / 3)$ & 0,01 & a & $(1 / 3)$ & $<0,01$ & a & $(0 / 1)$ \\
\hline As & $\mathrm{mg} / \mathrm{kg}$ & $<0,11$ & a & $(0 / 1)$ & $<0,11$ & a & $(0 / 3)$ & $<0,11$ & a & $(0 / 3)$ & $<0,11$ & a & $(0 / 1)$ \\
\hline $\mathrm{Cr}$ & $\mathrm{mg} / \mathrm{kg}$ & 0,68 & a & $(1 / 1)$ & 0,12 & $\mathrm{~b}$ & $(2 / 3)$ & 1,9 & c & $(1 / 3)$ & $<0,07$ & $\mathrm{~b}$ & $(0 / 1)$ \\
\hline $\mathrm{Ni}$ & $\mathrm{mg} / \mathrm{kg}$ & 0,79 & a & $(1 / 1)$ & 0,53 & a & $(3 / 3)$ & 1,6 & a & $(1 / 3)$ & $<0,07$ & $\mathrm{~b}$ & $(0 / 1)$ \\
\hline $\mathrm{Cu}$ & $\mathrm{mg} / \mathrm{kg}$ & 9 & a & $(1 / 1)$ & $<0,57$ & b & $(0 / 3)$ & $<0,57$ & b & $(0 / 3)$ & $<0,57$ & $\mathrm{~b}$ & $(0 / 1)$ \\
\hline $\mathrm{Zn}$ & $\mathrm{mg} / \mathrm{kg}$ & 37 & a & $(1 / 1)$ & 0,43 & a & $(1 / 3)$ & 0,63 & a & $(1 / 3)$ & $<1,1$ & a & $(0 / 1)$ \\
\hline $\mathrm{Ba}$ & $\mathrm{mg} / \mathrm{kg}$ & 2,8 & a & $(1 / 1)$ & $<0,16$ & a & $(0 / 3)$ & $<0,16$ & a & $(0 / 3)$ & $<0,16$ & a & $(0 / 1)$ \\
\hline v & $\mathrm{mg} / \mathrm{kg}$ & $<0,28$ & a & $(0 / 1)$ & $<0,28$ & a & $(0 / 3)$ & $<0,28$ & a & $(0 / 3)$ & $<0,28$ & a & $(0 / 1)$ \\
\hline U & $\mathrm{mg} / \mathrm{kg}$ & $<0,062$ & a & $(0 / 1)$ & $<0,062$ & a & $(0 / 3)$ & $<0,062$ & a & $(0 / 3)$ & $<0,062$ & a & $(0 / 1)$ \\
\hline Co & $\mathrm{mg} / \mathrm{kg}$ & NA & & $(0 / 0)$ & NA & & $(0 / 0)$ & NA & & $(0 / 0)$ & NA & & $(0 / 0)$ \\
\hline $\mathrm{Se}$ & $\mathrm{mg} / \mathrm{kg}$ & NA & & $(0 / 0)$ & NA & & $(0 / 0)$ & NA & & $(0 / 0)$ & NA & & $(0 / 0)$ \\
\hline
\end{tabular}

* Spuiwater, gemeten vóór OO en IW

** Gemeten ná OO en IW

NA niet onderzocht 

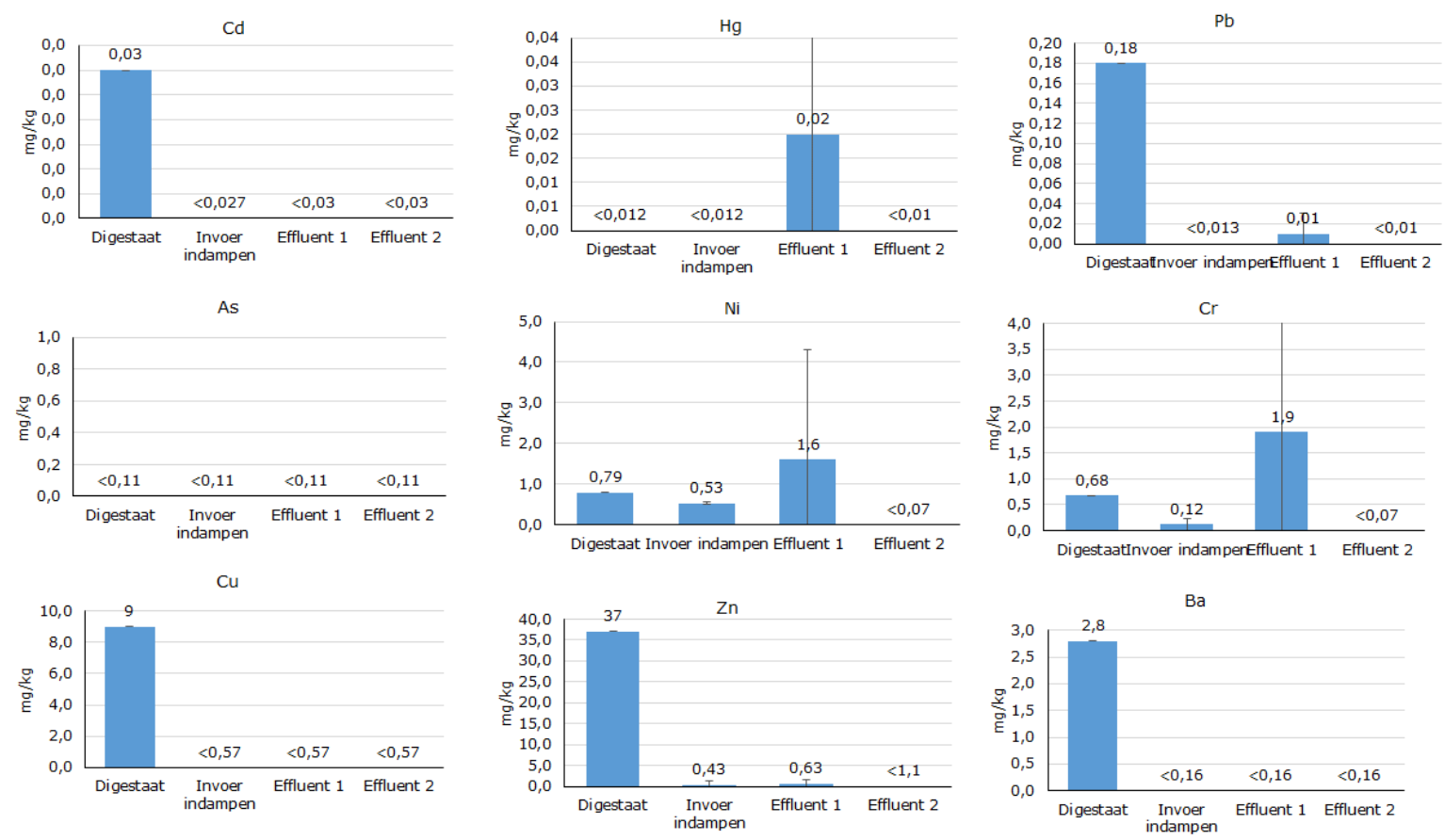

u
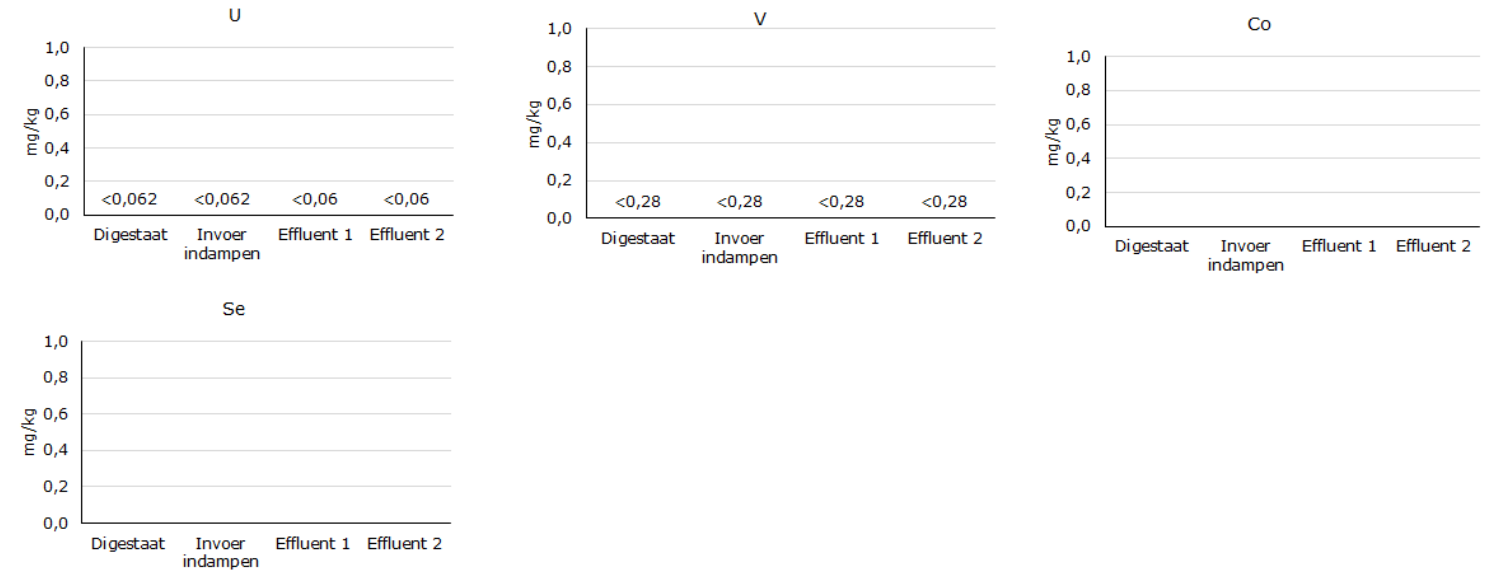

Figuur 3.22 Gemiddelde concentraties en variaties (plus en min 1 x standaarddeviatie) van zware metalen in processtromen van de indampinstallatie. Alleen de parameters met ten minste één reële meetwaarde zijn in de figuur weergegeven. Indampen-1 is gemeten vóór, indampen-2 ná OO en IW.

In digestaat, invoer indamper en effluent-1 werden meerdere zware metalen in lage concentraties gemeten. In effluent-2, ná 00 en IW, werden geen zware metalen gedetecteerd. Net als voor de andere MVI's moet hier opgemerkt worden dat het effect van de processtappen op de verwijdering van zware metalen onvoldoende kon worden aangetoond vanwege de hoge detectiegrenzen van de toegepaste analysemethoden. 
Tabel 25 Gemiddelde concentraties van hormoonstoffen en antibiotica in processtromen van de indampinstallatie. Waarden boven de detectiegrens zijn vetgedrukt. Betekenis van de letters in superscript: verschillende letters per regel betekent dat het verschil in concentratie tussen processtromen significant is $(P<0,05)$. Tussen haakjes staat het aantal waarnemingen $>$ detectiegrens en het totale aantal waarnemingen.

\begin{tabular}{|c|c|c|c|c|c|c|c|c|c|c|c|c|c|}
\hline Parameter & Eenheid & & Dige & estaat & Invoe & ind & amper & & Iuen & $n t-1 *$ & Effl & uent & $\mathrm{t}-2 * *$ \\
\hline Hormoonstoffen & & & & & & & & & & & & & \\
\hline ER-CALUX & ng $17 B \mathrm{EEQ} / \mathrm{g}$ & 1,8 & a & $(2 / 2)$ & 0,36 & a & $(2 / 2)$ & NA & $\mathrm{a}$ & $(0 / 0)$ & 0,02 & a & $(2 / 2)$ \\
\hline Antibiotica & & & & & & & & & & & & & \\
\hline Oxytetracycline & $\mu \mathrm{g} / \mathrm{kg}$ & $<10$ & a & $(0 / 2)$ & $<9,6$ & a & $(0 / 5)$ & 1,3 & a & $(1 / 3)$ & $<8,0$ & a & $(0 / 3)$ \\
\hline Doxycycline & $\mu \mathrm{g} / \mathrm{kg}$ & 75 & a & $(2 / 2)$ & 18 & $\mathrm{~b}$ & $(5 / 5)$ & 1 & c & $(1 / 3)$ & $<4,0$ & d & $(0 / 3)$ \\
\hline Sulfadiazine & $\mu \mathrm{g} / \mathrm{kg}$ & 21 & a & $(2 / 2)$ & 7 & $\mathrm{~b}$ & $(4 / 5)$ & $<1,0$ & c & $(0 / 3)$ & $<1,0$ & c & $(0 / 3)$ \\
\hline Sulfadimidine & $\mu \mathrm{g} / \mathrm{kg}$ & $<1$ & a & $(0 / 2)$ & $<1$ & a & $(0 / 5)$ & $<1,0$ & a & $(0 / 3)$ & $<1,0$ & a & $(0 / 3)$ \\
\hline Trimethoprim & $\mu \mathrm{g} / \mathrm{kg}$ & $<2$ & a & $(0 / 2)$ & $<1$ & $\mathrm{~b}$ & $(0 / 5)$ & $<1,0$ & $\mathrm{~b}$ & $(0 / 3)$ & $<1,0$ & $\mathrm{~b}$ & $(0 / 3)$ \\
\hline Ciprofloxacine & $\mu \mathrm{g} / \mathrm{kg}$ & $<13$ & a & $(0 / 2)$ & $<3,4$ & $\mathrm{a}$ & $(0 / 5)$ & 0,67 & $\mathrm{~b}$ & $(1 / 3)$ & $<1,0$ & a & $(0 / 3)$ \\
\hline Enrofloxacine & $\mu \mathrm{g} / \mathrm{kg}$ & $<30$ & a & $(0 / 2)$ & $<9$ & a & $(0 / 5)$ & 0,67 & $\mathrm{~b}$ & $(1 / 3)$ & $<1,0$ & a & $(0 / 3)$ \\
\hline Flumequine & $\mu \mathrm{g} / \mathrm{kg}$ & 1,5 & a & $(2 / 2)$ & 1 & $\mathrm{a}$ & $(3 / 5)$ & 0,33 & a & $(1 / 3)$ & $<1,0$ & $\mathrm{~b}$ & $(0 / 3)$ \\
\hline Lincomycine & $\mu \mathrm{g} / \mathrm{kg}$ & $<7,5$ & a & $(0 / 2)$ & $<2,6$ & $\mathrm{a}$ & $(0 / 5)$ & $<1,3$ & a & $(0 / 3)$ & $<1,0$ & a & $(0 / 3)$ \\
\hline Tilmicosine & $\mu \mathrm{g} / \mathrm{kg}$ & $<2,5$ & a & $(0 / 2)$ & $<2,2$ & $\mathrm{a}$ & $(0 / 5)$ & 0,67 & $\mathrm{~b}$ & $(1 / 3)$ & 2,5 & b & $(1 / 2)$ \\
\hline Florfenicol & $\mu \mathrm{g} / \mathrm{kg}$ & $<1$ & a & $(0 / 2)$ & $<1$ & $\mathrm{a}$ & $(0 / 5)$ & $<1,0$ & a & $(0 / 3)$ & $<1,0$ & a & $(0 / 3)$ \\
\hline Chloortetracycline & $\mu \mathrm{g} / \mathrm{kg}$ & $<15$ & a & $(0 / 2)$ & $<13$ & a & $(0 / 5)$ & $<5,3$ & a & $(0 / 3)$ & $<6,7$ & a & $(0 / 3)$ \\
\hline Tetracycline & $\mu \mathrm{g} / \mathrm{kg}$ & $<13$ & a & $(0 / 2)$ & $<9$ & $\mathrm{a}$ & $(0 / 5)$ & $<2,0$ & a & $(0 / 3)$ & $<3,3$ & a & $(0 / 3)$ \\
\hline Minocycline & $\mu \mathrm{g} / \mathrm{kg}$ & $<45$ & a & $(0 / 2)$ & $<30$ & a & $(0 / 5)$ & $<4,7$ & a & $(0 / 3)$ & $<12$ & a & $(0 / 3)$ \\
\hline Methacycline & $\mu \mathrm{g} / \mathrm{kg}$ & $<18$ & a & $(0 / 2)$ & $<16$ & $\mathrm{a}$ & $(0 / 5)$ & $<2,7$ & a & $(0 / 3)$ & $<10$ & a & $(0 / 3)$ \\
\hline Sulfathiazol & $\mu \mathrm{g} / \mathrm{kg}$ & $<5$ & a & $(0 / 2)$ & $<2,2$ & $\mathrm{a}$ & $(0 / 5)$ & $<1,0$ & a & $(0 / 3)$ & $<1,3$ & a & $(0 / 3)$ \\
\hline Sulfapyridine & $\mu \mathrm{g} / \mathrm{kg}$ & $<3$ & a & $(0 / 2)$ & $<1,8$ & $\mathrm{a}$ & $(0 / 5)$ & $<1,0$ & a & $(0 / 3)$ & $<1,0$ & a & $(0 / 3)$ \\
\hline Sulfamerazine & $\mu \mathrm{g} / \mathrm{kg}$ & $<1$ & a & $(0 / 2)$ & $<1$ & a & $(0 / 5)$ & $<1,0$ & a & $(0 / 3)$ & $<1,0$ & ${ }^{a}$ & $(0 / 3)$ \\
\hline Sulfamoxol & $\mu \mathrm{g} / \mathrm{kg}$ & $<1,5$ & a & $(0 / 2)$ & $<1,4$ & $\mathrm{a}$ & $(0 / 5)$ & $<1,3$ & a & $(0 / 3)$ & $<1,0$ & a & $(0 / 3)$ \\
\hline Sulfamethizol & $\mu \mathrm{g} / \mathrm{kg}$ & $<1,5$ & a & $(0 / 2)$ & $<1,4$ & a & $(0 / 5)$ & $<1,0$ & a & $(0 / 3)$ & $<1,0$ & a & $(0 / 3)$ \\
\hline Sulfamethoxypyridazine & $\mu \mathrm{g} / \mathrm{kg}$ & $<1$ & a & $(0 / 2)$ & $<1$ & $\mathrm{a}$ & $(0 / 5)$ & $<1,0$ & a & $(0 / 3)$ & $<1,0$ & a & $(0 / 3)$ \\
\hline Sulfamonomethoxine & $\mu \mathrm{g} / \mathrm{kg}$ & $<1,5$ & a & $(0 / 2)$ & $<1,4$ & a & $(0 / 5)$ & $<1,0$ & a & $(0 / 3)$ & $<1,3$ & a & $(0 / 3)$ \\
\hline Sulfachloorpyridazine & $\mu \mathrm{g} / \mathrm{kg}$ & $<3$ & a & $(0 / 2)$ & $<2,2$ & a & $(0 / 5)$ & $<1,0$ & a & $(0 / 3)$ & $<1,0$ & a & $(0 / 3)$ \\
\hline Sulfadoxine & $\mu \mathrm{g} / \mathrm{kg}$ & $<1$ & a & $(0 / 2)$ & $<1$ & a & $(0 / 5)$ & $<1,0$ & a & $(0 / 3)$ & $<1,0$ & a & $(0 / 3)$ \\
\hline Sulfamethoxazol & $\mu \mathrm{g} / \mathrm{kg}$ & $<1,5$ & a & $(0 / 2)$ & $<1,6$ & a & $(0 / 5)$ & $<1,0$ & a & $(0 / 3)$ & $<1,0$ & a & $(0 / 3)$ \\
\hline Sulfisoxazol & $\mu \mathrm{g} / \mathrm{kg}$ & $<2,5$ & a & $(0 / 2)$ & $<1,8$ & a & $(0 / 5)$ & $<1,0$ & a & $(0 / 3)$ & $<1,3$ & a & $(0 / 3)$ \\
\hline Sulfadimethoxine & $\mu \mathrm{g} / \mathrm{kg}$ & $<1$ & a & $(0 / 2)$ & $<1,2$ & a & $(0 / 5)$ & $<1,0$ & a & $(0 / 3)$ & $<1,0$ & $\mathrm{a}$ & $(0 / 3)$ \\
\hline Sulfaquinoxaline & $\mu \mathrm{g} / \mathrm{kg}$ & $<2,5$ & a & $(0 / 2)$ & $<2$ & a & $(0 / 5)$ & $<1,0$ & a & $(0 / 3)$ & $<1,3$ & a & $(0 / 3)$ \\
\hline Sulfacetamide & $\mu \mathrm{g} / \mathrm{kg}$ & $<1$ & a & $(0 / 2)$ & $<1,8$ & $\mathrm{a}$ & $(0 / 5)$ & $<1,0$ & a & $(0 / 3)$ & $<1,0$ & a & $(0 / 3)$ \\
\hline Sulfaphenazol & $\mu \mathrm{g} / \mathrm{kg}$ & $<12,5$ & a & $(0 / 2)$ & $<10$ & a & $(0 / 5)$ & $<4,0$ & a & $(0 / 3)$ & $<4,0$ & a & $(0 / 3)$ \\
\hline Dapson & $\mu \mathrm{g} / \mathrm{kg}$ & $<1$ & a & $(0 / 2)$ & $<1$ & a & $(0 / 5)$ & $<1,0$ & a & $(0 / 3)$ & $<1,0$ & a & $(0 / 3)$ \\
\hline Marbofloxacine & $\mu g / k g$ & $<10$ & a & $(0 / 2)$ & $<3$ & a & $(0 / 5)$ & $<1,0$ & a & $(0 / 3)$ & $<1,0$ & $\mathrm{a}$ & $(0 / 3)$ \\
\hline Norfloxacine & $\mu \mathrm{g} / \mathrm{kg}$ & $<22,5$ & a & $(0 / 2)$ & $<13$ & a & $(0 / 5)$ & $<4,3$ & a & $(0 / 3)$ & $<1,3$ & a & $(0 / 3)$ \\
\hline Danofloxacine & $\mu \mathrm{g} / \mathrm{kg}$ & $<27,5$ & a & $(0 / 2)$ & $<7,6$ & a & $(0 / 5)$ & $<1,0$ & a & $(0 / 3)$ & $<1,0$ & a & $(0 / 3)$ \\
\hline Sarafloxacine & $\mu \mathrm{g} / \mathrm{kg}$ & $<50$ & a & $(0 / 2)$ & $<12$ & $\mathrm{a}$ & $(0 / 5)$ & $<6,3$ & a & $(0 / 3)$ & $<3,7$ & a & $(0 / 3)$ \\
\hline Difloxacine & $\mu \mathrm{g} / \mathrm{kg}$ & $<25$ & a & $(0 / 2)$ & $<6,6$ & a & $(0 / 5)$ & $<1,0$ & a & $(0 / 3)$ & $<1,0$ & a & $(0 / 3)$ \\
\hline Oxolinezuur & $\mu \mathrm{g} / \mathrm{kg}$ & $<10$ & a & $(0 / 2)$ & $<5,2$ & a & $(0 / 5)$ & $<1,0$ & a & $(0 / 3)$ & $<1,3$ & a & $(0 / 3)$ \\
\hline Nalidixinezuur & $\mu \mathrm{g} / \mathrm{kg}$ & $<5$ & a & $(0 / 2)$ & $<2,4$ & a & $(0 / 5)$ & $<1,0$ & a & $(0 / 3)$ & $<1,0$ & a & $(0 / 3)$ \\
\hline Levofloxacin/ofloxacin & $\mu \mathrm{g} / \mathrm{kg}$ & $<10$ & a & $(0 / 2)$ & $<3,8$ & a & $(0 / 5)$ & $<2,3$ & a & $(0 / 3)$ & $<4,0$ & a & $(0 / 3)$ \\
\hline Trovafloxacin & $\mu \mathrm{g} / \mathrm{kg}$ & $<10$ & a & $(0 / 2)$ & $<2$ & a & $(0 / 5)$ & $<1,7$ & a & $(0 / 3)$ & $<1,0$ & $\mathrm{a}$ & $(0 / 3)$ \\
\hline Erythromycine & $\mu \mathrm{g} / \mathrm{kg}$ & $<4$ & a & $(0 / 2)$ & $<14$ & $\mathrm{a}$ & $(0 / 5)$ & $<1,7$ & a & $(0 / 3)$ & $<1,0$ & $\mathrm{a}$ & $(0 / 3)$ \\
\hline
\end{tabular}




\begin{tabular}{|c|c|c|c|c|c|c|c|c|c|c|c|c|c|}
\hline \multirow{2}{*}{$\begin{array}{l}\text { Parameter } \\
\text { Tylosine }\end{array}$} & \multirow{2}{*}{$\begin{array}{l}\text { Eenheid } \\
\mu \mathrm{g} / \mathrm{kg}\end{array}$} & \multicolumn{3}{|c|}{ Digestaat } & \multicolumn{3}{|c|}{ Invoer indamper } & \multicolumn{3}{|c|}{ Effluent-1* } & \multicolumn{3}{|c|}{ Effluent-2** } \\
\hline & & $<2$ & a & $(0 / 2)$ & $<8,4$ & a & $(0 / 5)$ & $<10$ & a & $(0 / 3)$ & $<4,3$ & a & $(0 / 3)$ \\
\hline Josamycine & $\mu \mathrm{g} / \mathrm{kg}$ & $<1$ & $\mathrm{a}$ & $(0 / 2)$ & $<15$ & a & $(0 / 5)$ & $<1,7$ & a & $(0 / 3)$ & $<1,0$ & a & $(0 / 3)$ \\
\hline Spiramycine & $\mu \mathrm{g} / \mathrm{kg}$ & $<10$ & $\mathrm{a}$ & $(0 / 2)$ & $<11$ & a & $(0 / 5)$ & $<35$ & a & $(0 / 3)$ & $<27$ & a & $(0 / 3)$ \\
\hline Neospiramycine 1 & $\mu \mathrm{g} / \mathrm{kg}$ & $<3,5$ & $\mathrm{a}$ & $(0 / 2)$ & $<8,2$ & a & $(0 / 5)$ & $<18$ & a & $(0 / 3)$ & $<4,0$ & a & $(0 / 3)$ \\
\hline Tiamulin & $\mu \mathrm{g} / \mathrm{kg}$ & $<5$ & $\mathrm{a}$ & $(0 / 2)$ & $<1,4$ & a & $(0 / 5)$ & $<1,0$ & a & $(0 / 3)$ & $<1,0$ & a & $(0 / 3)$ \\
\hline Tulathromycine & $\mu \mathrm{g} / \mathrm{kg}$ & $<1$ & $\mathrm{a}$ & $(0 / 2)$ & $<6,4$ & a & $(0 / 5)$ & $<1,0$ & $\mathrm{a}$ & $(0 / 3)$ & $<1,0$ & a & $(0 / 3)$ \\
\hline Pirlimycine & $\mu g / k g$ & $<1$ & $\mathrm{a}$ & $(0 / 2)$ & $<3,4$ & a & $(0 / 5)$ & $<1,3$ & a & $(0 / 3)$ & $<1,0$ & a & $(0 / 3)$ \\
\hline Valnemulin & $\mu \mathrm{g} / \mathrm{kg}$ & $<2$ & $\mathrm{a}$ & $(0 / 2)$ & $<1,2$ & a & $(0 / 5)$ & $<1,0$ & a & $(0 / 3)$ & $<2,3$ & a & $(0 / 3)$ \\
\hline Tylvalosine & $\mu g / k g$ & $<2$ & $\mathrm{a}$ & $(0 / 2)$ & $<1,6$ & a & $(0 / 5)$ & $<3,3$ & a & $(0 / 3)$ & $<1,7$ & a & $(0 / 3)$ \\
\hline Natamycin & $\mu \mathrm{g} / \mathrm{kg}$ & $<1,5$ & $\mathrm{a}$ & $(0 / 2)$ & $<13$ & a & $(0 / 5)$ & $<4,3$ & $\mathrm{a}$ & $(0 / 3)$ & $<1,0$ & a & $(0 / 3)$ \\
\hline Gamithromycine & $\mu \mathrm{g} / \mathrm{kg}$ & $<1,5$ & $\mathrm{a}$ & $(0 / 2)$ & $<2$ & a & $(0 / 5)$ & $<2,0$ & a & $(0 / 3)$ & $<2,0$ & a & $(0 / 3)$ \\
\hline Tildipirosine & $\mu \mathrm{g} / \mathrm{kg}$ & $<3$ & $\mathrm{a}$ & $(0 / 2)$ & $<2,8$ & a & $(0 / 5)$ & $<21$ & $\mathrm{a}$ & $(0 / 3)$ & $<1,5$ & a & $(0 / 3)$ \\
\hline Vancomycine & $\mu \mathrm{g} / \mathrm{kg}$ & $<4$ & $\mathrm{a}$ & $(0 / 2)$ & $<17$ & a & $(0 / 5)$ & $<4,3$ & a & $(0 / 3)$ & $<1,0$ & a & $(0 / 3)$ \\
\hline Azithromycine & $\mu \mathrm{g} / \mathrm{kg}$ & $<1$ & $\mathrm{a}$ & $(0 / 2)$ & $<2$ & a & $(0 / 5)$ & $<2,3$ & a & $(0 / 3)$ & $<1,0$ & a & $(0 / 3)$ \\
\hline Clarithromycine & $\mu g / k g$ & $<1$ & $\mathrm{a}$ & $(0 / 2)$ & $<6$ & a & $(0 / 5)$ & $<1,0$ & a & $(0 / 3)$ & $<1,0$ & a & $(0 / 3)$ \\
\hline
\end{tabular}

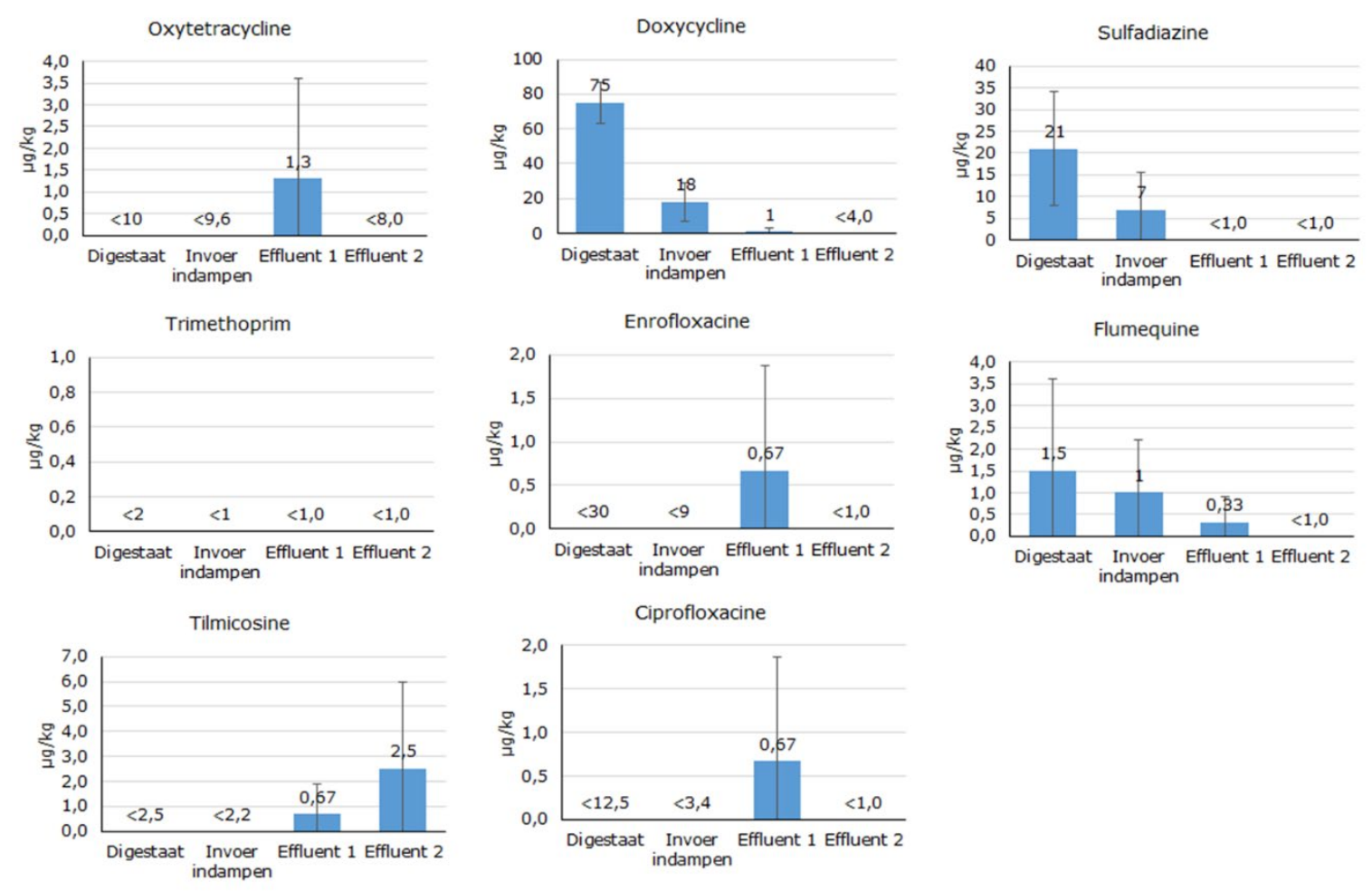

Figuur 3.23 Gemiddelde concentraties en variaties (plus en min 1 x standaarddeviatie) van antibiotica in processtromen van de indampinstallatie. Alleen de parameters met ten minste één reële meetwaarde zijn in de figuur weergegeven. Indampen-1 is gemeten vóór, indampen-2 ná OO en IW.

De antibiotica met effluent-waarden boven de detectiegrens zijn aangetroffen in monsters die werden genomen ten tijde dat nabehandeling met $\mathrm{OO}$ en IW nog niet werd toegepast, met uitzondering van tilmicosine dat ook in een effluentmonster ná behandeling met $\mathrm{OO}$ en IW werd aangetoond. Het effluent na $\mathrm{OO}$ en IW is nagenoeg vrij van antibiotica. In dit effluent werden wel hormoonstoffen aangetroffen. 
Tabel 26 Gemiddelde concentraties van micro-organismen in processtromen van de indampinstallatie. Tussen haakjes staat het aantal positieve waarnemingen en het totale aantal waarnemingen. Voor berekening van de gemiddelde concentratie is voor monsters met waarnemingen onder de detectielimiet deze limiet aangenomen. De eenheid is de decadische logaritme van de concentratie in $\mathrm{KVE} / \mathrm{g}(\log 10(\mathrm{KVE} / \mathrm{g})$. Betekenis van de letters in superscript: verschillende letters per regel betekent dat het verschil in concentratie in vergelijking met de ruwe mest significant is $(p<0,05)$

\begin{tabular}{|c|c|c|c|c|c|c|c|c|c|c|c|c|c|c|}
\hline \multirow[b]{2}{*}{ E. coli } & \multicolumn{3}{|c|}{ Ruwe mest } & \multicolumn{4}{|c|}{ Digestaat } & \multicolumn{3}{|c|}{ Invoer indamper } & \multicolumn{4}{|c|}{ Effluent } \\
\hline & 5,72 & a & $(1 / 1)$ & 2,45 & & & $(0 / 2)$ & $-0,04$ & & $(0 / 4)$ & $-2,66$ & & & $(0 / 3)$ \\
\hline Enterokokken & 4,94 & a & $(1 / 1)$ & 3,12 & 0,34 & $\mathrm{~b}$ & $(2 / 2)$ & 2,30 & 0,14 & b $\quad(4 / 4)$ & $-2,67$ & & & $(0 / 3)$ \\
\hline $\begin{array}{l}\text { Sporen van } \\
\text { sulfietreducerende } \\
\text { Clostridia }\end{array}$ & 4,97 & a & $(1 / 1)$ & 4,75 & 0,26 & a & $(2 / 2)$ & 3,50 & 0,28 & a $\quad(3 / 4)$ & $-1,46$ & 0,80 & $\mathrm{~b}$ & $(3 / 3)$ \\
\hline Sporen van C. difficile & 2,65 & a & $(1 / 1)$ & 0,95 & & a & $(1 / 2)$ & 0,83 & 0,42 & a $\quad(3 / 4)$ & $-2,67$ & & & $(0 / 3)$ \\
\hline ESBL E. coli & 3,68 & a & $(1 / 1)$ & 1,32 & & & $(0 / 2)$ & $-0,04$ & & $(0 / 4)$ & $-2,67$ & & & $(0 / 3)$ \\
\hline Bacteriofagen & NA & & & NA & & & & NA & & & NA & & & \\
\hline Campylobacter & Aanwezig & & $(1 / 1)$ & Afwezig & & & $(0 / 2)$ & Afwezig & & $(0 / 3)$ & Afwezig & & & $(0 / 2)$ \\
\hline MRSA & Aanwezig & & $(1 / 1)$ & Afwezig & & & $(0 / 2)$ & Afwezig & & $(0 / 4)$ & Afwezig & & & $(0 / 3)$ \\
\hline Hepatitis E virus & NA & & & NA & & & & NA & & & NA & & & \\
\hline
\end{tabular}
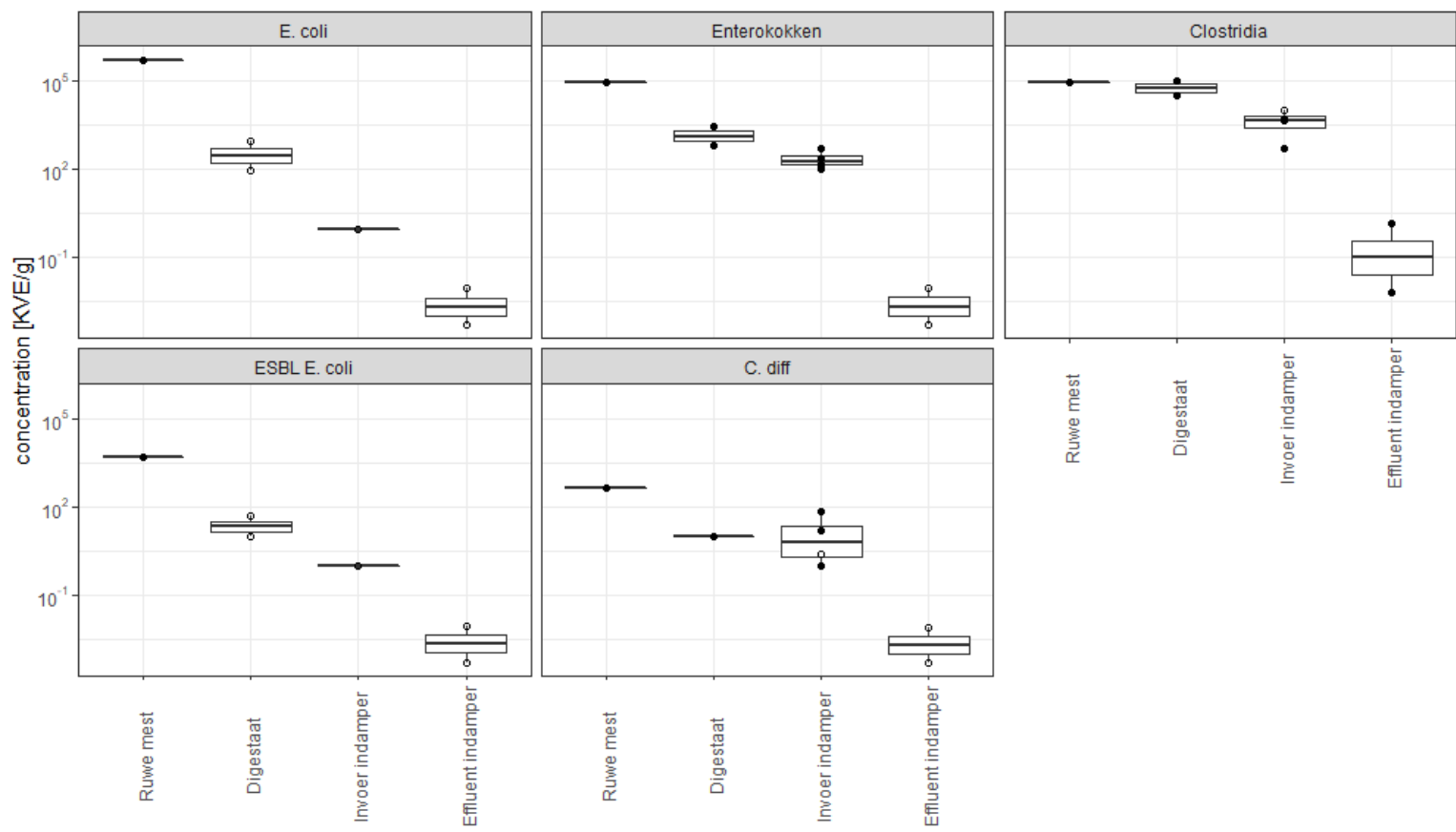

Figuur 3.24 Concentraties en hun variatie (mediaan als horizontale lijn, 25-75 percentiel als box, uitschieters als punten met een verticale verbinding naar de box)) van micro-organismen in processtromen van de indampinstallaties. Waarden onder de detectielimiet zijn vervangen door de detectielimiet en met open symbolen aangeduid, waarden boven de detectielimiet zijn door gevulde symbolen aangeduid.

Tabel 26 en Figuur 3.24 tonen dat vergisting tot reductie van bacteriën leidt. Dit geldt vooral voor $E$. coli en ESBL $E$. coli, en in mindere mate voor sporen van Clostridia en enterokokken. Deze bevinding komt overeen met eerdere bevindingen van Hoeksma et al (2015). In het effluent van de indamper konden bacteriologische parameters, met uitzondering van sporen van Clostridia, niet meer worden aangetoond. 


\subsection{Hormoonstoffen in processtromen}

Figuur 3.25 toont de gemiddelde concentraties en variaties van hormoonstoffen in de processtromen van de 4 MVI's.
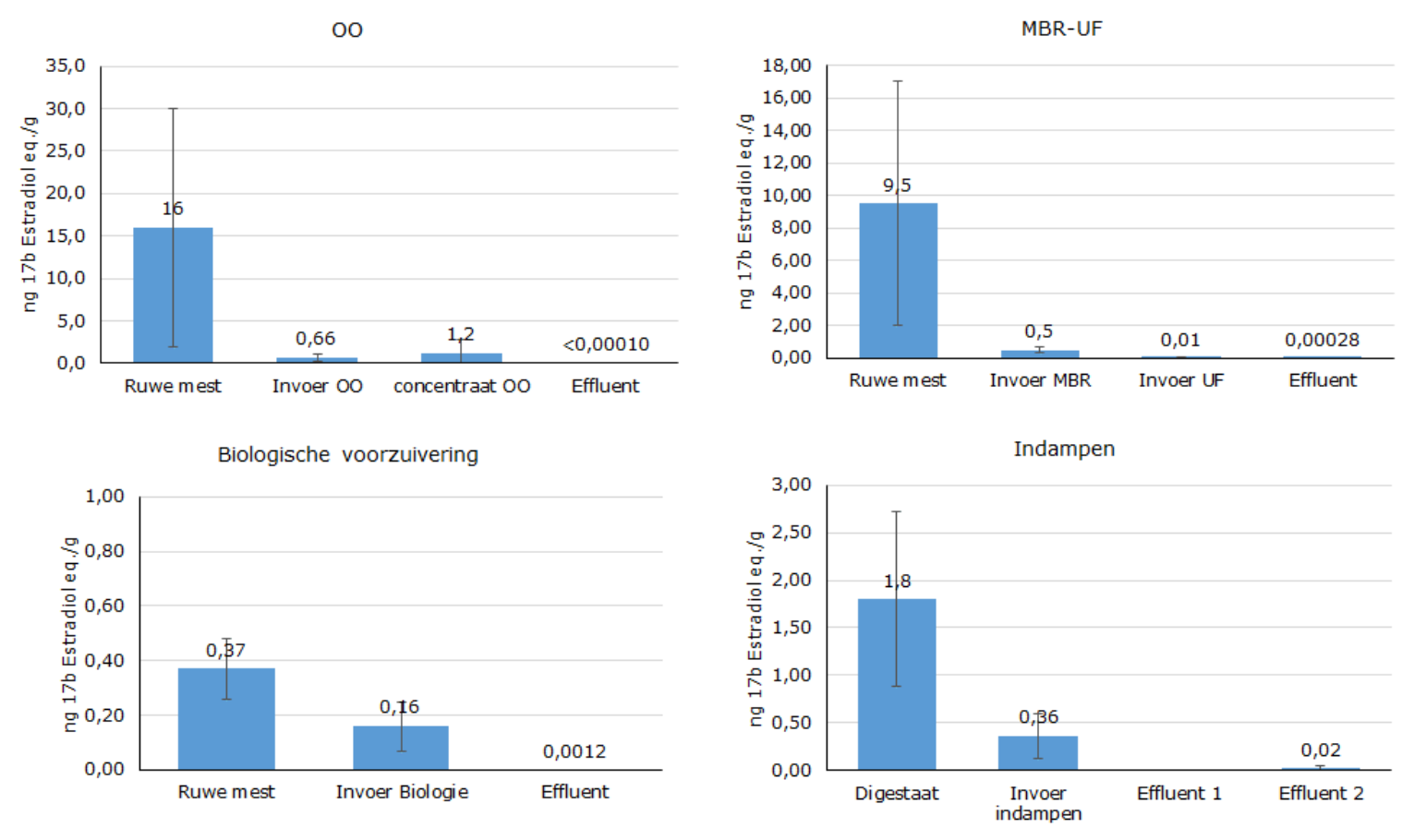

Figuur 3.25 Gemiddelde concentraties en variaties (plus en min 1 x standaarddeviatie) van hormoonstoffen (ER-CALUX) in processtromen van vier typen MVI's.

In de ruwe mest van OO, MBR-UF en biologische voorzuivering en in het digestaat van de indampinstallatie zijn hormoonstoffen in meetbare concentraties gedetecteerd. Hoewel ze in de verwerkingsprocessen grotendeels worden verwijderd zijn in de effluenten van MBR-UF, biologische voorzuivering en indampen-2 hormoonstoffen nog in meetbare concentraties aangetroffen. In het effluent van $\mathrm{OO}$ zijn geen hormoonstoffen aangetoond.

Rouwgoor et al (2016) houden voor oppervlaktewater voor estrogene activiteit als grenswaarde 0,5 ng $\mathrm{EEQ} / \mathrm{I}$ aan. De effluenten van OO, MBR-UF en biologische zuivering voldoen hier aan. In de twee monsters van het effluent van indampen na behandeling met $\mathrm{OO}$ en IW werden hogere concentraties dan deze grenswaarde gemeten, n.I. 2 ng EEQ/l. 


\section{$4 \quad$ Correlatie tussen parameters}

Eén van de kenmerken van indicatoren, die zouden kunnen dienen voor het monitoren van de efficiëntie van de toegepaste zuiveringstechniek en de kwaliteit van het effluent van een MVI, is dat ze een nauwe samenhang moeten hebben met de meest kritische voorzorgparameters. Ter ondersteuning van de keuze van mogelijke indicatoren is de mate van correlatie vastgesteld tussen de gemeten parameters in de effluenten van OO, MBR-UF en indampen. Het effluent van biologische voorzuivering is buiten beschouwing gelaten omdat dit effluent niet bedoeld is om geloosd te worden op oppervlaktewater.

Correlatie tussen algemene chemische parameters, zware metalen en antibiotica

Figuur 4.1 toont de correlatiematrix van de gemeten chemische parameters die in de effluenten van OO, MBR-UF en indampen zijn aangetroffen.

Figuur 4.2 geeft een overzicht van de chemische parameters en het aantal parameters waarmee ze een sterke, een matige en een geringe correlatie hebben.

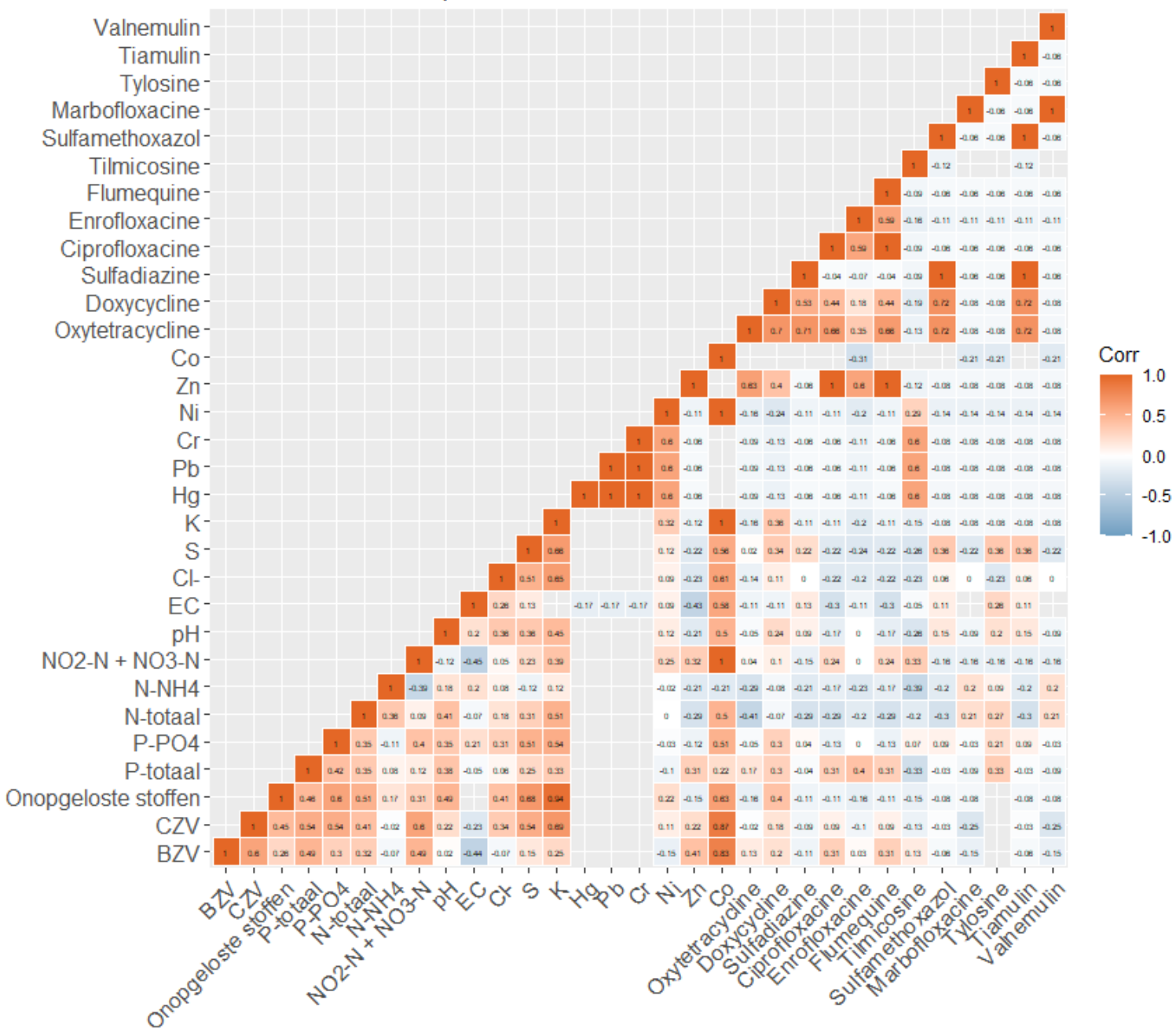

Figuur 4.1 Correlaties tussen de algemene chemische parameters, zware metalen en antibiotica die in de effluenten van OO, MBR-UF en indampen zijn aangetroffen. De getallen geven de Kendall's Tau correlatiecoëfficiënten aan (theoretische range, -1 tot +1 ). 


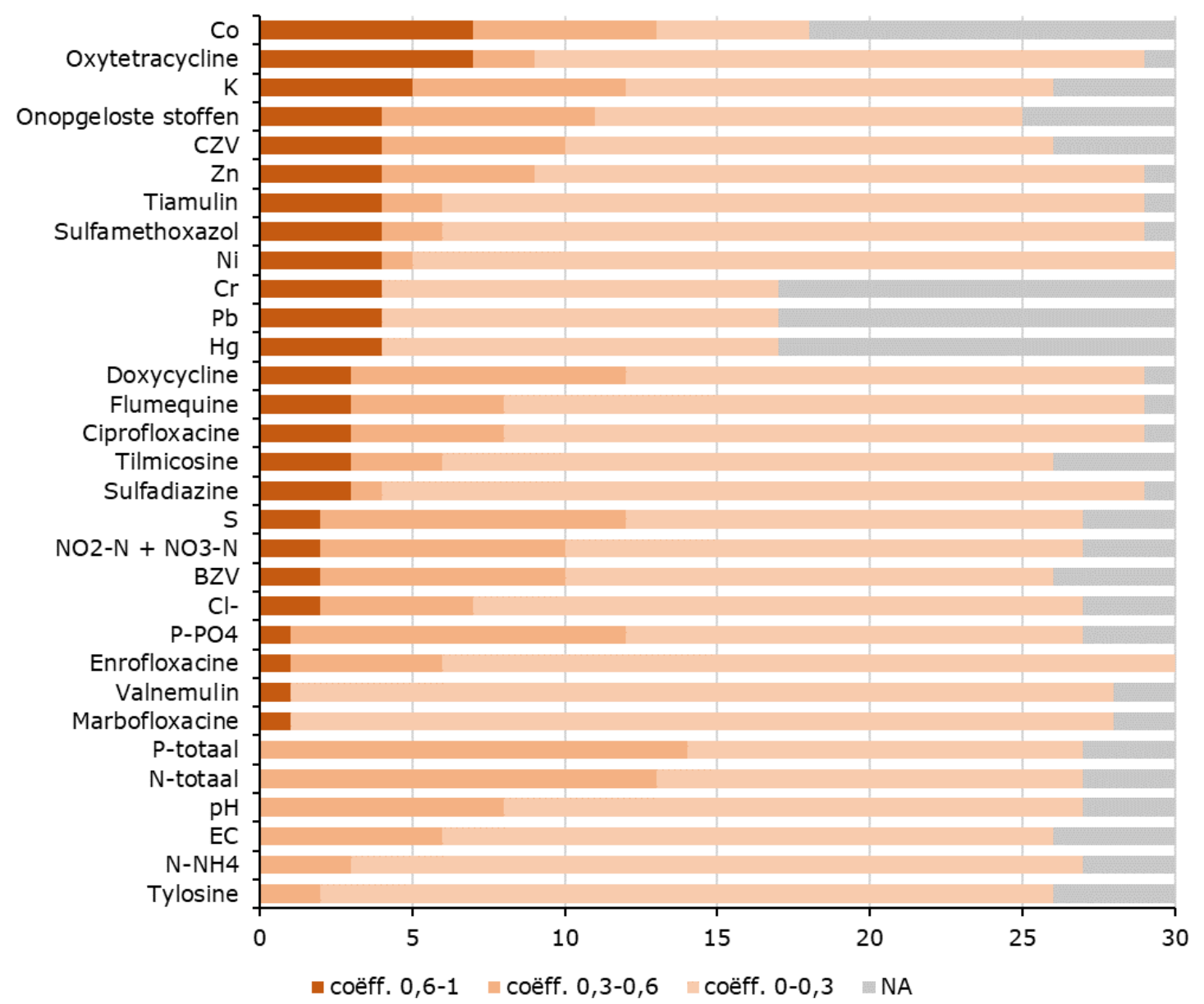

Figuur 4.2 Gemeten chemische parameters en het aantal parameters waarmee ze een sterke (correlatiecoëff. 0,6-1), een matige (correlatiecoëff. 0,3-0,6) en een geringe (correlatiecoëff. 0-0,3) correlatie hebben.

Figuren 4.1 en 4.2 laten zien dat van de algemene chemische parameters kalium, onopgeloste stoffen en CZV de sterkste correlatie vertonen met andere parameters in de effluenten. Opvallend is de geringe correlatie van EC met de andere parameters. Kalium toont vooral een sterke band met een aantal andere algemene chemische parameters, met name CZV, onopgeloste stoffen, chloride en zwavel, en met kobalt. De correlatie tussen $\mathrm{K}$ en andere zware metalen en antibiotica is gering. Hetzelfde kan gezegd worden van onopgeloste stoffen en CZV, die eveneens samenhang vertonen met algemene chemische parameters en veel minder met zware metalen en antibiotica.

Correlatie tussen algemene chemische parameters en micro-organismen

Figuur 4.3 toont de correlatiematrix van de algemene chemische parameters en de micro-organismen in de effluenten van 00, MBR-UF en indampen.

Figuur 4.4 geeft een overzicht van de algemene chemische parameters en de micro-organismen en het aantal parameters waarmee ze een sterke, een matige en een geringe correlatie hebben. 


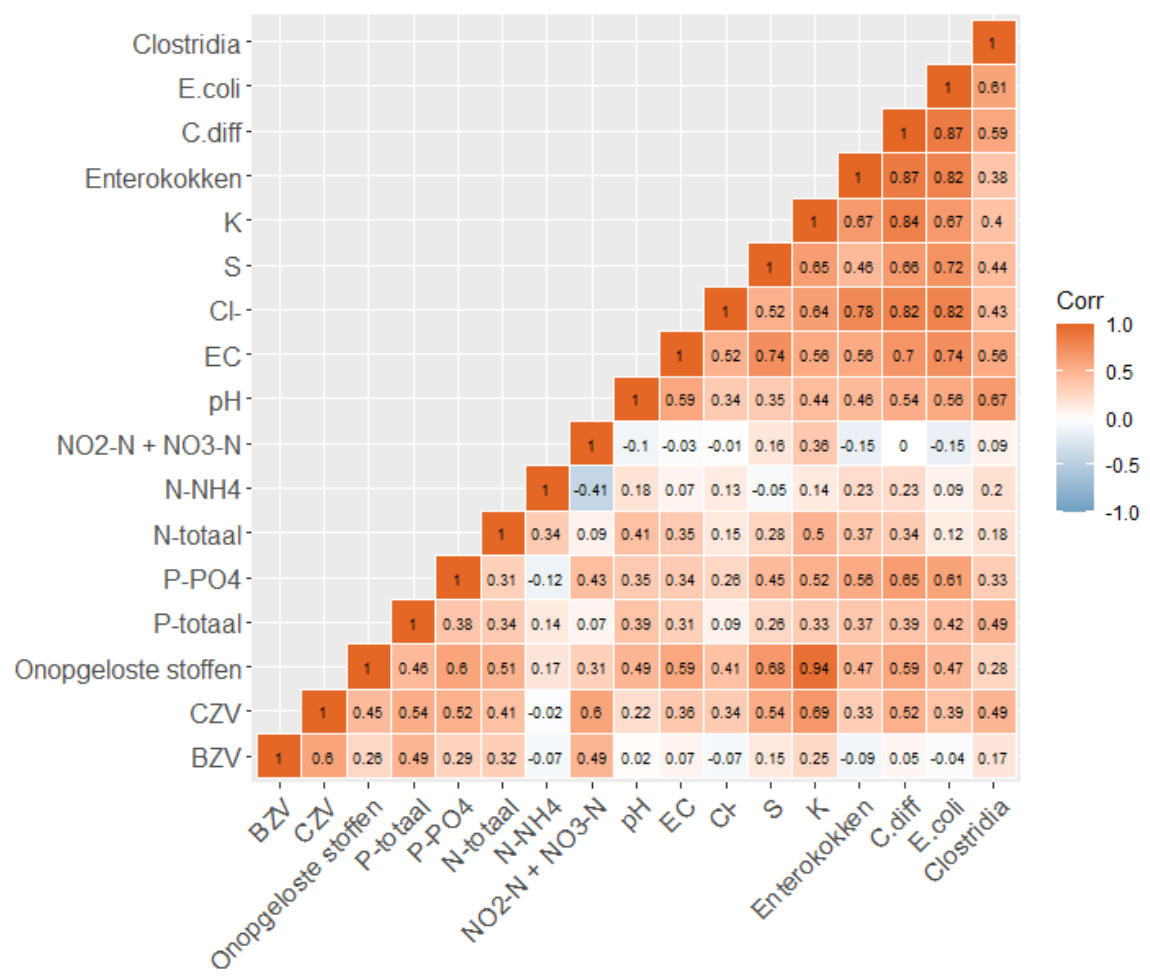

Figuur 4.3 Correlaties tussen de algemene chemische parameters en de biologische parameters in de effluenten van OO, MBR-UF en indampen. De getallen geven de Kendall's Tau correlatiecoëfficiënten aan (theoretische range, -1 tot +1 ).

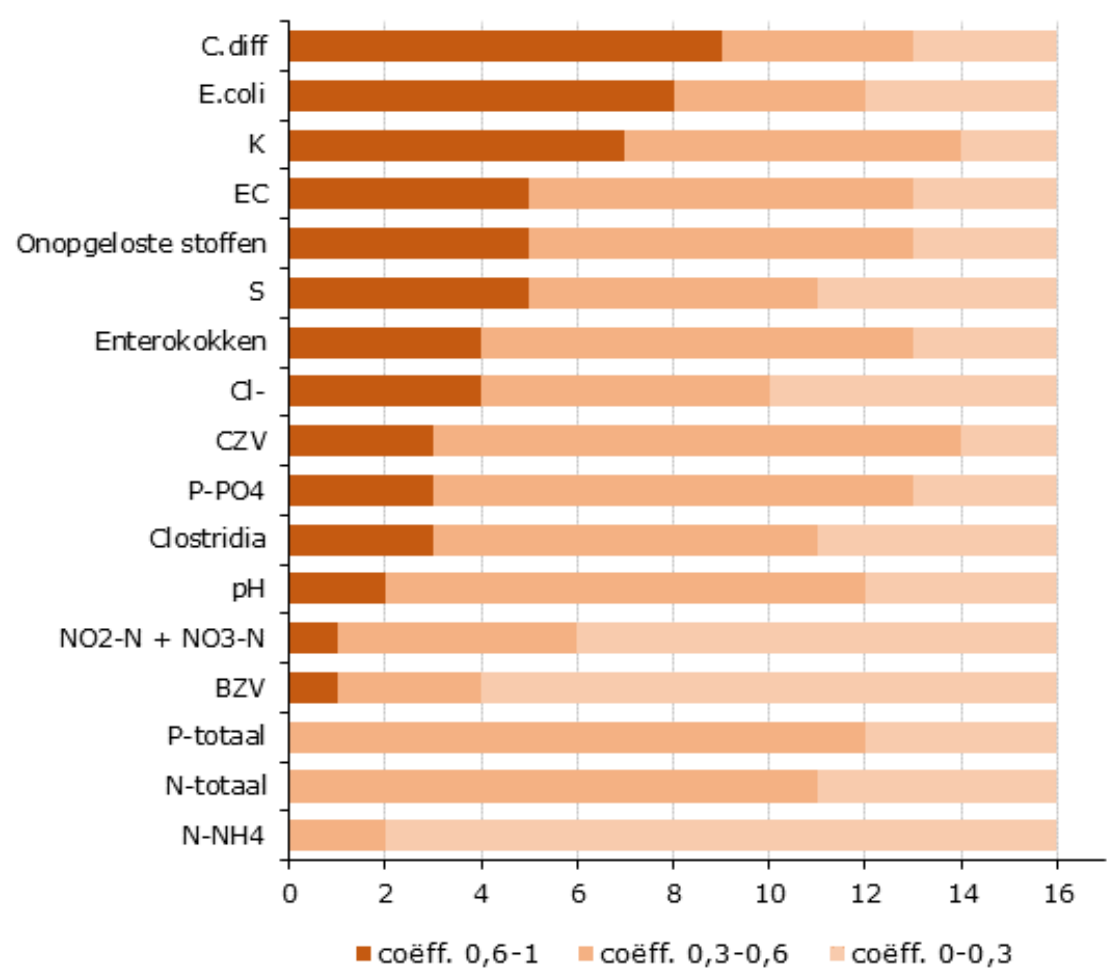

Figuur 4.4 Gemeten algemene chemische parameters en biologische parameters en het aantal parameters waarmee ze een sterke (correlatiecoëff. 0,6-1), een matige (correlatiecoëff. $0,3-0,6$ ) en een geringe (correlatiecoëff. 0-0,3) correlatie hebben. 
Figuren 4.3 en 4.4 laten zien dat de biologische parameters onderling sterk gecorreleerd zijn en dat deze parameters een matige tot sterke correlatie vertonen met de chemische parameters $\mathrm{K}_{1} \mathrm{~S}, \mathrm{Cl}^{-}, \mathrm{EC}$ en $\mathrm{pH}$. Ook bestaat een sterke correlatie tussen $\mathrm{P}_{-} \mathrm{PO}_{4}$ en $\mathrm{C}$. diff. en $E$. coli. De andere chemische stoffen vertonen weinig samenhang met de biologische parameters.

Geconcludeerd kan worden dat het voor de biologische parameters niet veel uitmaakt welke gemeten wordt gezien de onderlinge correlatie. E. coli en enterokokken zouden als indicator ingezet kunnen worden omdat ze algemeen in relatief hoge concentraties in mest voorkomen. Van de algemene chemische parameters lijken $\mathrm{K}$ en EC (wegens eenvoud van meten) het meest in aanmerking te komen als indicator voor de verwijdering van micro-organismen. Hierbij wordt opgemerkt dat $\mathrm{K}$ alleen in de afvoer van MBR-UF is gevonden en niet in de effluenten van OO en indampen (na OO) en $\mathrm{K}$ daarom minder geschikt is als indicator parameter bij het monitoren van deze effluenten. Verder wordt opgemerkt dat de hier vermelde correlaties zijn gebaseerd op een beperkt aantal meetwaarden en daarom met voorzichtigheid moeten worden geïnterpreteerd. 


\section{$5 \quad$ Discussie}

\subsection{Algemeen}

\section{Opzet en uitvoering meetcampagne}

Voor deze meetcampagne werden verschillende typen mestverwerkingsinstallaties geselecteerd waarmee alle technieken waren vertegenwoordigd die heden ten dage in Nederland worden toegepast bij verwerking van varkensdrijfmest met een te lozen effluent als restproduct. Door ook kalvergiervoorbewerkingsinstallaties bij de meetcampagne te betrekken waren de twee belangrijkste (vloeibare) mestsoorten, wat betreft het jaarlijks verwerkte mestvolume, vertegenwoordigd (Hoeksma et al, 2020b). Vaste mestsoorten zoals pluimveemest, die ook een substantieel deel uitmaken van het verwerkte mestvolume, zijn in het kader van dit onderzoek niet relevant omdat bij de verwerking van pluimveemest (vooral verbranding) geen waterig effluent aan de orde is.

Bij de opzet van de meetcampagne werd uitgegaan van twee installaties per type MVI. Voor de installaties met omgekeerde osmose en biologische voorzuivering kon worden geselecteerd uit een aantal installaties die al meerdere jaren in bedrijf zijn. Van de typen MBR-UF en indampen was ten tijde van de selectie voor deze meetcampagne slechts één installatie operationeel. Beide installaties verkeerden tijdens de meetcampagne in een fase waarin hooguit enkele maanden op volle capaciteit werd gedraaid, waarin de bedrijfsvoering varieerde en waarin in het geval van indampen een extra behandelingstechniek aan het zuiveringsproces werd toegevoegd. Dit had tot gevolg dat van deze twee installaties slechts een beperkt aantal betrouwbare meetgegevens kon worden verzameld, terwijl van $\mathrm{OO}$ en biologische voorzuivering een degelijke en meer uitgebreide dataset kon worden verkregen. Op basis van de meetresultaten van MBR-UF en indampen, vóór en ná toevoeging van een omgekeerde osmose unit en een ionenwisselaar, konden daarom slechts indicaties over de zuiveringsprestaties en de kwaliteit van het effluent worden gegeven. Op basis van de meetgegevens die van $\mathrm{OO}$ en biologische voorzuivering werden verkregen konden meer stellige uitspraken worden gedaan.

\section{Ingangsmaterialen van de MVI's}

De ingangsmaterialen van de beschouwde mestverwerkingsinstallaties, te weten varkensdrijfmest en kalvergier, zijn representatief voor de mest die op Nederlandse vleesvarkensbedrijven en vleeskalverbedrijven wordt geproduceerd wat betreft de gehalten aan algemene chemische parameters (KWIN-veehouderij, 2020). Voor het ingangsmateriaal van de indampinstallatie, bestaande uit het digestaat uit een co-vergister met varkensmest en bijproducten als substraat, kan geen referentie met representatieve informatie worden gegeven. De samenstelling van digestaat is sterk afhankelijk van de samenstelling van de bijproducten. Het substraat van de co-vergister ten tijde van de meetcampagne bestond voor $50 \%$ uit varkensmest van het eigen bedrijf en voor $50 \%$ uit een mengsel van snijmais, graanresten, cacaodoppen, rijstslijpmeel en havermout pellets, producten die alle voorkomen op de z.g. positieve lijst (Bijlage Aa onderdeel IV van de Uitvoeringsregeling Meststoffenwet). De samenstelling van digestaat wordt tevens bepaald door de procesvoering van de co-vergister, met als belangrijke variabelen de procestemperatuur, de organische stofbelasting en de hydraulische verblijftijd.

\subsection{Referentieniveaus}

In het kader van deze studie kan onder een referentieniveau worden verstaan, een waarde van algemene parameters en voorzorgparameters (indicatoren) aan de hand waarvan kan worden beoordeeld of een techniek als BBT op de juiste wijze op MVI-afvalwater is toegepast voordat beoordeling van de resulterende lozing op het oppervlaktewater plaats vindt. Benadrukt wordt dat referentieniveaus prestatiekenmerken zijn voor technieken om MVI-afvalwater als BBT te behandelen en dus niet beschouwd moeten worden als richtgetallen voor de op te nemen grenswaarden in een lozingsvergunning. Deze laatste zijn veelal maatwerk en worden bepaald door de lozingssituatie in 
samenspraak tussen bevoegd gezag voor het verstrekken van een lozingsvergunning en de initiatiefnemer van de MVI.

De uitgevoerde meetcampagne heeft voor een uitgebreide selectie van parameters meetgegevens gegenereerd, waarmee een eerste indicatief beeld is verkregen van de prestatiekenmerken van verschillende MVI technieken voor algemene chemische parameters, zware metalen, antibiotica en micro-organismen. Hoe omvangrijk ook, de dataset uit deze meetcampagne alleen is ontoereikend om daadwerkelijk de prestatiekenmerken voor BBT te kunnen vaststellen. Voor het verkrijgen van een uitgebreidere dataset zal gebruik gemaakt moeten worden van meetgegevens uit andere onderzoeken (Hoeksma et al, 2011; Hoeksma \& de Buisonjé, 2015; Hoeksma et al, 2021), die beschikbaar zijn bij het bevoegd gezag over MVI-effluenten en die worden gegenereerd door aanvullend onderzoek. Voor een meer gefundeerde afleiding is dus een groter gegevensbestand nodig.

De met deze meetcampagne verkregen dataset liet voor een aantal parameters wel een verschil in meetwaarden zien tussen de fysische technieken $\mathrm{OO}$ en indampen enerzijds en die van de biologische/fysische zuiveringstechniek MBR-UF anderzijds. Om deze reden worden voor deze beide typen zuiveringstechnieken prestatiekenmerken voor algemene chemische parameters ter indicatie gegeven (Tabel 27). Afleiding van deze prestatiekenmerken per techniek heeft 'door de oogharen' plaatsgevonden en is vanwege de beperkte dataset niet rekenkundig/statistisch afgeleid.

Tabel 27 Indicatieve prestatiekenmerken voor algemene chemische parameters in effluenten van MVI's die gebruik maken van de zuiveringstechniek OO of MBR-UF.

\begin{tabular}{lccc} 
Parameter & Eenheid & 00 & MBR-UF \\
$\mathrm{BZV}$ & $\mathrm{mg} / \mathrm{l}$ & 2 & 15 \\
\hline $\mathrm{CZV}$ & $\mathrm{mg} / \mathrm{l}$ & 5 & 900 \\
\hline Onopgeloste stoffen & $\mathrm{mg} / \mathrm{l}$ & $<5$ & 15 \\
\hline $\mathrm{P}$-totaal & $\mathrm{mg} / \mathrm{l}$ & 5 & 8 \\
\hline $\mathrm{P}-\mathrm{PO}_{4}$ & $\mathrm{mg} / \mathrm{l}$ & 2 & 8 \\
\hline $\mathrm{N}$-totaal & $\mathrm{mg} / \mathrm{l}$ & 15 & 70 \\
\hline $\mathrm{N}-\mathrm{NH}_{4}$ & $\mathrm{mg} / \mathrm{l}$ & 16 & 30 \\
\hline $\mathrm{NO}_{2}-\mathrm{N}+\mathrm{NO}_{3}-\mathrm{N}$ & $\mathrm{mg} / \mathrm{l}$ & 0,5 & 15 \\
\hline $\mathrm{pH}$ & & $5-9$ & $5-9$ \\
\hline $\mathrm{EC} *$ & $\mathrm{mS} / \mathrm{cm}$ & 0,4 & \\
\hline $\mathrm{Cl}$ * & $\mathrm{mg} / \mathrm{l}$ & 50 & \\
\hline $\mathrm{S} *$ & $\mathrm{mg} / \mathrm{l}$ & 15 & \\
\hline $\mathrm{K} *$ & $\mathrm{mg} / \mathrm{l}$ & 0 &
\end{tabular}

Over het algemeen is de kwaliteit van het behandelde water na OO/indampen beter dan na MBR-UF, zowel wat betreft de algemene chemische parameters als de voorzorgparameters. Maar voor beide typen zuiveringstechnieken zal het bevoegd gezag op basis van de lozingssituatie o.a. middels een immissietoets beoordelen of en welke aanvullende behandeling nog vereist is om tot een aanvaardbare kwaliteit van het te lozen water te komen.

Zware metalen

De meetresultaten van zware metalen laten zien dat de detectiegrenzen van de toegepaste analysemethode veelal boven de JG-MKN en MAC-MKN waarden voor zware metalen liggen. De vermelde detectiegrenzen zijn hoog. In de ruwe varkensmest worden vooral $\mathrm{Zn}$ en $\mathrm{Cu}$ in hoge concentraties aangetroffen, gevolgd door de metalen $\mathrm{Cr}$, Ni en Ba. Ook in de waterige invoer naar de $\mathrm{OO}$ en MBR-UF voorzieningen worden deze metalen in meetbare concentraties aangetroffen. Het opstellen van prestatiekenmerken voor beide technieken lijkt dan ook alleen zinvol voor deze metalen. Door de relatief hoge detectiegrenzen van de toegepaste analysemethode voor zware metalen in het effluent zijn er geen bruikbare meetdata beschikbaar om de prestatiekenmerken voor deze metalen af te leiden. Aanbevolen wordt dan ook de analyse van zware metalen in de effluenten te herhalen met 
een analysemethode met een lagere detectiegrens, zodat toetsing van effluenten aan normwaarden voor zware metalen in oppervlaktewater mogelijk wordt. Aan deze aanbeveling is reeds gevolg gegeven (zie Addendum). Uit deze aanvullende analyses blijkt dat de concentraties metalen in het OO-effluent doorgaans onder de normwaarden voor oppervlaktewater liggen en in het effluent van MBR-UF er boven.

Antibiotica

Uit de meetresultaten van OO/indampen en MBR-UF blijkt dat vooral de antibiotica oxytetracycline, doxycycline en sulfadiazine in het effluent kunnen voorkomen. Dit is overeenkomstig de verwachting omdat varkensmest doorgaans de uitgangsmest is en deze antibiotica veel in de varkenshouderij worden gebruikt. Bij kalvergier komen ook andere antibiotica voor, waaronder flumequine. De concentraties van oxytetracycline, doxycycline en sulfadiazine in het effluent lagen doorgaans onder de detectiegrens van de toegepaste analysemethode en enkele meetbare concentraties van oxytetraen doxycycline overschreden de ecotoxicologische grenswaarden (PNEC's). Dit geeft aan dat bij een goede procesvoering van de technieken OO, indampen en MBR-UF geen antibiotica in het effluent aantoonbaar mogen zijn of dat de gemeten concentraties net boven de detectiegrens van de toegepaste analysemethode liggen.

Micro-organismen

Uit de meetresultaten blijkt dat de bacteriologische verontreiniging in het effluent van de verwerkingstechnieken OO, indampen en MBR-UF veelal met meer dan 4 log-eenheden is gedaald ten opzichte van het ingangsmateriaal mest. MBR-UF blijft hierbij achter ten opzichte van de andere twee technieken, vooral wat betreft enterokokken, sporen van sulfietreducerende Clostridia en somatische colifagen. De gemiddelde concentratie in MBR-UF-effluent van E. coli was $4 \mathrm{kve} / 100 \mathrm{ml}$, van enterokokken $15 \mathrm{kve} / 100 \mathrm{ml}$ en van Clostridia en somatische colifagen respectievelijk $100 \mathrm{kve} / 100 \mathrm{ml}$ en $120 \mathrm{kve} / 100 \mathrm{ml}$. De concentraties van E. coli en enterokokken vallen binnen de normen voor zwemwater van uitstekende kwaliteit, de enige bestaande norm voor E. coli en enterokokken in water. Er bestaat geen norm voor Clostridia en somatische colifagen voor zwemwater. Waterkwaliteitsrichtwaarden voor somatische colifagen in zwemwater, gebaseerd op risico voor andere virussen, werden wel in de wetenschappelijke literatuur afgeleid als $60 \mathrm{kve} / 100 \mathrm{ml}$, wat overeenkomt met de gevonden concentraties van bacteriofagen in MBR-UF effluent (Boehm, 2019). Concentraties van somatische colifagen in zwemwater kunnen rond 10-100 kve/100 ml liggen (McMinn et al, 2017). Het is dus niet uit te sluiten dat bij concentraties van bacteriofagen zoals in deze studie gevonden, andere pathogene virussen in concentraties kunnen voorkomen die de geschiktheid van het ontvangende water voor recreatie negatief beïnvloeden. Tabel 28 geeft indicatieve prestatiekenmerken voor de bacteriologische parameters op basis van de data verkregen in deze meetcampagne.

Tabel 28 Indicatieve prestatiekenmerken voor de bacteriologische parameters in effluenten van de MVI's die gebruik maken van de zuiveringstechniek OO of MBR-UF (eenheid log10 kve/g).

\begin{tabular}{lcc} 
Parameter & 00 & MBR-UF \\
E coli & $-2,0(\mathrm{ie}, 0,01 \mathrm{kve} / \mathrm{g})$ & $-1,0(\mathrm{ie}, 0,1 \mathrm{kve} / \mathrm{g})$ \\
\hline Enterokokken & $-2,0$ & $-1,0$ \\
\hline Sporen van sulfietreducerende Clostridia & $-2,0$ & $0,0(\mathrm{ie}, 1 \mathrm{kve} / \mathrm{g})$ \\
\hline C. difficile & $-2,0$ & $-1,0$ \\
\hline ESBL . coli & $-2,0$ & $-2,0$ \\
\hline Bacteriofagen & $-2,0$ & 0,0 \\
\hline
\end{tabular}




\subsection{Indicatieve waarden}

De zuiveringsprestaties van de fysische techniek OO en de biologisch-fysische zuiveringstechniek MBR-UF verschillen van elkaar. Hierdoor is het niet mogelijk om voor beide technieken dezelfde indicatieve waarden voor de voorzorgparameters te benoemen om alternatieve technieken op gelijkwaardigheid te kunnen beoordelen. Deze toetsing dient plaats te vinden per type techniek, waarin de beoogde lozingssituatie leidend zal zijn. Bij verdere uitwerking kunnen de in de vorige paragraaf vermelde indicatieve prestatiekenmerken per techniektype fungeren als indicatieve waarden, waar de alternatieve techniek aan getoetst kan worden.

\subsection{Indicatoren}

Voor het monitoren van de efficiëntie van de toegepaste zuiveringstechniek voor het vrijkomende water van een MVI kunnen de volgende parameters als indicator in aanmerking komen:

- $\quad$ BZV: verstrekt informatie over het functioneren van het biologisch zuiveringsproces en de resulterende zuurstofvraag in ontvangend oppervlaktewater;

- P-totaal: verstrekt informatie over de P-belasting voor ontvangend oppervlaktewater;

- $\quad \mathrm{N}-\mathrm{NH} 4$ : wordt in de huidige praktijk van waterkwaliteitsbeheer veelal gebruikt als sleutelparameter (vanwege de toxiciteit van ongedissocieerd NH3) die bepalend kan zijn voor de beoordeling van de waterkwaliteit voor het ontvangende oppervlaktewater;

- Onopgeloste bestanddelen: verstrekt informatie over de conditie van en het functioneren van membranen;

- $\quad \mathrm{EC}, \mathrm{K}$ en $\mathrm{Cl}-$ : verstrekken informatie over de conditie en het functioneren van OOmembranen;

- $\quad \mathrm{Cu}$ en $\mathrm{Zn}$ : komen algemeen voor in mest en zijn representatief voor verwijdering van overige metalen;

- Oxytetracycline en doxycycline: komen algemeen voor in mest en zijn representatief voor verwijdering van overige antibiotica;

- $\quad$ E. coli en intestinale enterokokken: komen algemeen voor in mest en zijn representatief voor de verwijdering van bacteriën en antibiotica-resistente bacteriën.

- Somatische colifagen: komen algemeen voor in mest en zijn representatief voor de verwijdering van virussen.

Om de zuiveringsprestaties van een zuiveringstechniek goed te kunnen monitoren, is het veelal niet nodig om alle hierboven vermelde indicatoren te meten in het effluent, maar lijkt een selectie hiervan voldoende om een goed beeld te krijgen van het functioneren van het zuiveringsproces. De lozingssituatie is bij deze keuze bepalend.

De correlatie tussen parameters, zoals in hoofdstuk 4 berekend, geeft geen ondersteuning voor de keuze van BZV, P-totaal en N-NH4 als indicatoren. Deze parameters laten juist een geringe samenhang zien met andere algemene parameters. $\mathrm{K}$ en EC lijken geschikt als indicator voor verwijdering van micro-organismen. Het aantal meetdata dat in deze studie is verkregen is echter niet toereikend om duidelijke keuzes voor indicatoren op te kunnen baseren. Het is aan te bevelen de correlatie tussen algemene parameters en voorzorgparameters beter in beeld te brengen op basis van een grotere dataset. Hierbij zou gebruik gemaakt kunnen worden van data verkregen uit meetcampagnes van gerelateerde onderzoeksprojecten, zoals recent onderzoek van Waterschap Aa en Maas en de pilot mineralenconcentraten van LNV.

De geschiktheid van indicatoren hangt echter ook af van de praktische toepasbaarheid; ze moeten relatief makkelijk te meten zijn en tegen zo laag mogelijke kosten. Daarnaast is de meetnauwkeurigheid een kenmerk om rekening mee te houden; deze neemt toe naarmate het concentratieniveau hoger is. Met het oog op deze factoren lijkt ammonium een betere kandidaat om te worden gebruikt als indicator dan BZV of P-totaal.

Zo heeft Waterschap Aa en Maas recent voorgesteld de monitoring van effluenten van OO-installaties te beperken tot ammonium, pH en EC. Metingen van het waterschap hebben aangetoond dat ammonium als indicator kan dienen voor de kwaliteit van effluenten van MVI's met OO omdat 
normoverschrijding bij lozingen van effluenten in de meeste gevallen ammonium betreft en dat aan de normen voor andere stoffen meestal wordt voldaan. 


\section{Literatuur}

Berendsen B.J.A., J. Lahr, C. Nibbeling, L.J.M. Jansen, I.E.A. Bongers, E.L. Wipfler and M.G.M. van de Schans (2018) The persistence of a broad range of antibiotics during calve, pig and broiler manure storage. Chemosphere. 204, p. 267-276.

Bouwknegt M, Rutjes SA, Reusken CB, Stockhofe-Zurwieden N, Frankena K, de Jong MC, de Roda Husman AM (2009) The course of hepatitis $E$ virus infection in pigs after contact-infection and intravenous inoculation. BMC Vet. Res. 2009, 5:7.

Hoeksma P., F.E. de Buisonjé, P.A.I. Ehlert en J.H. Horrevorts (2011) Mineralenconcentraten uit dierlijke mest. Monitoring in het kader van de pilot mineralenconcentraten. Wageningen Livestock Research Rapport 481.

Hoeksma P. en F.E. de Buisonjé (2015) Production of mineral concentrates from animal manure using reverse osmosis. Monitoring of pilot plants in 2012-2014. Wageningen UR Livestock Research, Report 858.

Hoeksma P., A.J.A. Aarnink, F.E. de Buisonjé, S.A. Rutjes en H. Blaak (2015) Effect van processtappen op overleving van micro-organismen bij mestverwerking. Wageningen Livestock Research, Rapport 893, blz. 29.

Hoeksma P., H. Schmitt, F. de Buisonjé, H. Pishgar Komleh and P. Ehlert (2020a) Quality of mineral concentrates. Results of monitoring plants of the Pilot Mineral Concentrate in 2019-2020. Wageningen Livestock Research (in voorbereiding).

Hoeksma P., A. Aarnink, T. de Koeijer, P.W. Blokland, L. Wipfler, N. Rakonjac, C. Moermond en J. Lahr (2020b) Milieurisico van antibiotica in mest voor bodem en grondwater beperkt. Tijdschrift Milieu 2020; juni: 46-52.

Kuiper P., D. Vroon, G. Rijs en S. Plette (2006) Mestverwerking en mogelijke emissies naar oppervlaktewater: uitgangspunten vanuit waterbeheer voor de verwerking van mest uit de landbouwsector. RIZA rapport 2006.031.

Lahr J., T. ter Laak en A. Derksen et al (2014) Screening van hot spots van nieuwe verontreinigingen. Een pilot studie in bodem, grondwater en oppervlaktewater. Wageningen Alterra-rapport 2538.

Lahr et al (2019) Diergeneesmiddelen in het milieu. Een synthese van de huidige kennis. Stowa Rapport 201926.

McMinn B.R, N.J. Ashbolt and A. Korajkic (2017) Bacteriopfages as indicators of feacal pollution and enteric virus removal. Applied Microbiology. Volume 65, Issue 1, July 2017 pages 11-26.

Rouwgoor C., A. Allema, P. Leendertse en J. van Vliet (2016) Diergeneesmiddelen en waterkwaliteit. Stowa Rapport 201626.

RVO.nl (2019) Normen en mestcodes aan en afvoer van (dierlijke) mest. Tabel 11 Mestbeleid 2019/2020 Tabellen.

Schmitt H. et al (2017) Bronnen van antibioticaresistentie in het milieu en mogelijke maatregelen RIVM Rapport 2017-0058.

Spielmeyer A. (2018) Occurrence and fate of antibiotics in manure during manure treatments: A short review. Sustainable Chemistry and Pharmacy Volume 9, September 2018, pages 76-86.

Sukul P. and M. Spiteller (2007) Fluorquinolone antibiotics in the environment. Reviews of environmental contamination and toxicology;191:131-62.

Voorthuizen E. van, C. Overgoor, F. de Buisonje, N. Verdoes, P. Hoeksma, F. van Herpen, J. LeeuwisTolboom (2016) Achtergronddocument vergunningenbeleid voor lozingen van afvalwater uit mestverwerkingsinstallaties. Royal Haskoning DHV. Referentie: WATBE3311R001F01WW. 


\section{Bijlage 1}

\section{Analyseresultaten Omgekeerde Osmose}

\begin{tabular}{|c|c|c|c|c|c|c|c|c|c|c|c|c|c|c|c|c|c|c|}
\hline \multirow[b]{2}{*}{ Parameter } & \multirow[b]{2}{*}{ Eenheid } & \multicolumn{4}{|c|}{ Ruwe mest } & \multicolumn{4}{|c|}{ Invoer RO } & \multicolumn{4}{|c|}{ Concentraat RO } & \multicolumn{5}{|c|}{ Effluent } \\
\hline & & Gem. & SD & Min & $\operatorname{Max}$ & Gem. & SD & Min & $\operatorname{Max}$ & Gem. & SD & Min & $\operatorname{Max}$ & Gem. & SD & Min & - & $\operatorname{Max}$ \\
\hline \multicolumn{19}{|c|}{ Algemene chemische parameters } \\
\hline$B Z V$ & $\mathrm{mg} / \mathrm{l}$ & 10490 & 5105 & 6880 & - 14100 & 3147 & 2335 & 780 & 6610 & 6146 & 3207 & 2000 & - $\quad 11200$ & 0,71 & 0,95 & 0 & - & 2 \\
\hline CZV & $\mathrm{mg} / \mathrm{l}$ & 76800 & 30830 & 55000 & - 98600 & 8507 & 6491 & 2190 & - 17400 & 17596 & 7957 & 7070 & $-\quad 28000$ & 1,1 & 3 & 0 & - & 8 \\
\hline $\begin{array}{l}\text { Onopgeloste } \\
\text { stoffen }\end{array}$ & $\mathrm{mg} / \mathrm{l}$ & NA & NA & 0 & 0 & 1150 & 1061 & 400 & 1900 & 2400 & 141 & 2300 & 2500 & $<5$ & $<0$ & $<5$ & - & $<5$ \\
\hline P-totaal & $\mathrm{mg} / \mathrm{kg}$ & 1556 & 243 & 1231 & 1900 & 52 & 48 & 2,3 & 120 & 90 & 77 & 15 & 200 & 2,4 & 2,5 & 0 & - & 7,1 \\
\hline P-PO4 & $\mathrm{mg} / \mathrm{kg}$ & 238 & 37 & 180 & 314 & 29 & 31 & 0,2 & 73 & 54 & 57 & 0 & 142 & 0,81 & 0,91 & 0 & - & 3 \\
\hline $\mathrm{N}$-totaal & $\mathrm{mg} / \mathrm{kg}$ & 5671 & 947 & 4536 & 7240 & 3124 & 626 & 2297 & 4050 & 7605 & 1341 & 4932 & 9631 & 7,2 & 6,7 & 0 & - & 18 \\
\hline $\mathrm{N}-\mathrm{NH}_{4}$ & $\mathrm{mg} / \mathrm{kg}$ & 3207 & 598 & 2356 & 4136 & 2618 & 460 & 1954 & 3481 & 6332 & 1137 & 4637 & 7775 & 16 & 8,2 & 0 & - & 26 \\
\hline $\mathrm{NO}_{2}-\mathrm{N}+\mathrm{NO}_{3}-\mathrm{N}$ & $\mathrm{mg} / \mathrm{kg}$ & 0,19 & 0,43 & 0 & 1,1 & 0,37 & 0,94 & 0 & 3 & 1,6 & 4 & 0 & 13 & 0,1 & 0,34 & 0 & - & 1,1 \\
\hline $\mathrm{pH}$ & $(-)$ & 7,7 & 0,11 & 7,6 & 8 & 7,8 & 0,27 & 7,3 & 8,1 & 8 & 0,55 & 7,4 & 9,1 & 7,2 & 1,1 & 4,4 & - & 8,1 \\
\hline EC & $\mathrm{mS}$ & 27 & 3,1 & 21 & 32 & 29 & 4,4 & 25 & 40 & 62 & 15 & 44 & 85 & 0,21 & 0,18 & 0,01 & - & 0,5 \\
\hline $\mathrm{Cl}-$ & $\mathrm{mg} / \mathrm{kg}$ & 1816 & 427 & 1068 & 2395 & 1618 & 392 & 1181 & 2552 & 3769 & 805 & 2576 & 4881 & 14 & 26 & 0 & - & 84 \\
\hline S & $\mathrm{mg} / \mathrm{kg}$ & 856 & 157 & 640 & 1120 & 1745 & 1630 & 270 & 5420 & 4816 & 4391 & 370 & - 11900 & 6,4 & 8,1 & 0 & - & 20 \\
\hline K & $\mathrm{mg} / \mathrm{kg}$ & 4245 & 775 & 3100 & 5800 & 3300 & 697 & 2600 & 5000 & 8091 & 1967 & 5000 & - 10700 & 0 & 0 & 0 & - & 0 \\
\hline \multicolumn{19}{|c|}{ Zware metalen } \\
\hline $\mathrm{Cd}$ & $\mathrm{mg} / \mathrm{kg}$ & 0,05 & 0,04 & 0,03 & 0,17 & $<0,027$ & $<0$ & $<0,027$ & $-<0,027$ & $<0,027$ & $<0$ & $<0,027$ & $-<0,027$ & $<0,027$ & $<0$ & $<0,027$ & - & $<0,027$ \\
\hline $\mathrm{Hg}$ & $\mathrm{mg} / \mathrm{kg}$ & $<0,01$ & $<0,006$ & $<0,012$ & $-<0,031$ & $<0,012$ & $<0$ & $<0,012$ & $-<0,012$ & $<0,012$ & $<0$ & $<0,012$ & $-<0,012$ & $<0,012$ & 0 & $<0,012$ & - & $<0,012$ \\
\hline $\mathrm{Pb}$ & $\mathrm{mg} / \mathrm{kg}$ & 0,19 & 0,18 & 0,07 & 0,59 & $<0,013$ & $<0$ & $<0,013$ & $-<0,013$ & $<0,013$ & $<0$ & $<0,013$ & $-<0,013$ & $<0,013$ & $<0$ & $<0,013$ & - & $<0,013$ \\
\hline
\end{tabular}




\begin{tabular}{|c|c|c|c|c|c|c|c|c|c|c|c|c|c|c|c|c|c|c|c|c|c|}
\hline As & $\mathrm{mg} / \mathrm{kg}$ & $<0,13$ & $<0,05$ & $<0,11$ & - & $<0,29$ & $<0,11$ & $<0$ & $<0,11$ & - & $<0,11$ & $<0,11$ & $<0$ & $<0,11$ & - & $<0,11$ & $<0,11$ & $<0$ & $<0,11$ & - & $<0,11$ \\
\hline $\mathrm{Cr}$ & $\mathrm{mg} / \mathrm{kg}$ & 0,93 & 0,6 & 0,59 & - & 2,7 & 0,01 & 0,04 & 0 & - & 0,13 & 0,05 & 0,05 & 0 & - & 0,11 & $<0,074$ & $<0$ & $<0,074$ & - & $<0,074$ \\
\hline $\mathrm{Ni}$ & $\mathrm{mg} / \mathrm{kg}$ & 1 & 0,86 & 0,57 & - & 3,6 & 0,27 & 0,12 & 0,15 & - & 0,6 & 0,46 & 0,18 & 0 & - & 0,69 & 0,01 & 0,04 & 0 & - & 0,14 \\
\hline $\mathrm{Cu}$ & $\mathrm{mg} / \mathrm{kg}$ & 26 & 17 & 16 & - & 75 & $<0,57$ & $<0$ & $<0,57$ & - & $<0,57$ & 0,32 & 0,38 & 0 & - & 0,89 & $<0,57$ & $<0$ & $<0,57$ & - & $<0,57$ \\
\hline $\mathrm{Zn}$ & $\mathrm{mg} / \mathrm{kg}$ & 95 & 72 & 56 & - & 310 & 0,37 & 0,64 & 0 & - & 1,4 & 0,81 & 0,95 & 0 & - & 2,3 & $<1,1$ & $<0$ & $<1,1$ & - & $<1,1$ \\
\hline $\mathrm{Ba}$ & $\mathrm{mg} / \mathrm{kg}$ & 5 & 4,7 & 2,3 & - & 19 & 0,03 & 0,07 & 0 & - & 0,18 & 0,09 & 0,13 & 0 & - & 0,29 & $<0,16$ & $<0$ & $<0,16$ & - & $<0,16$ \\
\hline v & $\mathrm{mg} / \mathrm{kg}$ & 0,35 & 0,57 & 0 & - & 1,8 & $<0,28$ & $<0$ & $<0,28$ & - & $<0,28$ & $<0,28$ & $<0$ & $<0,28$ & - & $<0,28$ & $<0,28$ & $<0$ & $<0,28$ & - & $<0,28$ \\
\hline U & $\mathrm{mg} / \mathrm{kg}$ & 0,04 & 0,08 & 0 & - & 0,23 & $<0,062$ & $<0$ & $<0,062$ & - & $<0,062$ & $<0,062$ & $<0$ & $<0,062$ & - & $<0,062$ & $<0,062$ & $<0$ & $<0,062$ & - & $<0,062$ \\
\hline Co & $\mathrm{mg} / \mathrm{kg}$ & 0,12 & 0,02 & 0,1 & - & 0,14 & NA & NA & 0 & - & 0 & NA & NA & 0 & - & 0 & $<0,016$ & $<0$ & $<0,016$ & - & $<0,016$ \\
\hline $\mathrm{Se}$ & $\mathrm{mg} / \mathrm{kg}$ & 0,26 & 0,04 & 0,19 & - & 0,31 & NA & NA & 0 & - & 0 & NA & NA & 0 & - & 0 & $<0,032$ & $<0$ & $<0,032$ & - & $<0,032$ \\
\hline
\end{tabular}

\section{Hormoonstoffen}

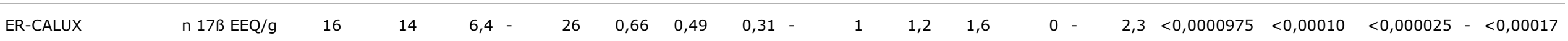

\section{Antibiotica}

\begin{tabular}{|c|c|c|c|c|c|c|c|c|c|c|c|c|c|c|c|c|c|c|c|}
\hline Oxytetracycline & $\mu \mathrm{g} / \mathrm{kg}$ & 217 & 210 & 16 & - & 550 & 67 & 178 & 0 & - & 700 & 41 & 47 & 0 & 166 & 2,9 & 11 & $0-$ & 43 \\
\hline Doxycycline & $\mu \mathrm{g} / \mathrm{kg}$ & 345 & 240 & 57 & - & 870 & 131 & 327 & 0 & - & 1300 & 57 & 56 & 0 & 156 & 4,5 & 17 & $0-$ & 67 \\
\hline Sulfadiazine & $\mu \mathrm{g} / \mathrm{kg}$ & 5,8 & 9,4 & 0 & - & 31 & 3,3 & 3,7 & 0 & - & 11 & 7,2 & 7,4 & 0 & 21 & 0,33 & 1,3 & $0-$ & 5 \\
\hline Sulfadimidine & $\mu \mathrm{g} / \mathrm{kg}$ & $<1$ & $<0$ & $<1$ & - & $<1$ & $<1$ & $<0$ & $<1$ & - & $<1$ & $<1,1$ & $<0,26$ & $<1$ & $<2$ & $<1$ & $<0$ & $<1-$ & $<1$ \\
\hline Trimethoprim & $\mu \mathrm{g} / \mathrm{kg}$ & $<1,5$ & $<0,5$ & $<1$ & - & $<2$ & $<1,4$ & $<0,63$ & $<1$ & - & $<3$ & $<1,7$ & $<1,0$ & $<1$ & $<5$ & $<1,1$ & $<0,2$ & $<1-$ & $<2$ \\
\hline Ciprofloxacine & $\mu \mathrm{g} / \mathrm{kg}$ & $<5,7$ & $<4,0$ & $<2$ & - & $<15$ & $<3,7$ & $<4,6$ & $<2$ & - & $<20$ & $<4,3$ & $<3,1$ & $<2$ & $<10$ & $<21$ & $<1,6$ & $<1-$ & $<5$ \\
\hline Enrofloxacine & $\mu \mathrm{g} / \mathrm{kg}$ & $<8,4$ & $<7,8$ & $<2$ & - & $<30$ & $<5,9$ & $<9,7$ & $<1$ & - & $<40$ & $<6,1$ & $<4,0$ & $<2$ & $<15$ & 0,13 & 0,35 & $0-$ & 1 \\
\hline Flumequine & $\mu \mathrm{g} / \mathrm{kg}$ & 6,3 & 21 & 0 & - & 72 & 0,13 & 0,52 & 0 & - & 2 & 0,13 & 0,52 & 0 & 2 & $<1$ & $<0$ & $<1-$ & $<1$ \\
\hline Lincomycine & $\mu \mathrm{g} / \mathrm{kg}$ & $<1,75$ & $<1,1$ & $<1$ & - & $<5$ & 0,13 & 0,52 & 0 & - & 2 & 0,13 & 0,52 & 0 & 2 & $<1,3$ & $<0,6$ & $<1-$ & $<3$ \\
\hline Tilmicosine & $\mu \mathrm{g} / \mathrm{kg}$ & 1,3 & 2,3 & 0 & - & 6 & 0,4 & 1,1 & 0 & - & 4 & 0,6 & 1,3 & 0 & 4 & $<26,5$ & $<32$ & $<2-$ & $<100$ \\
\hline Florfenicol & $\mu \mathrm{g} / \mathrm{kg}$ & $<1,7$ & $<1,5$ & $<1$ & - & $<5$ & $<1,4$ & $<1,1$ & $<1$ & - & $<5$ & $<1,9$ & $<2,5$ & $<1$ & $<10$ & $<1$ & $<0$ & $<1-$ & $<1$ \\
\hline Chloortetracycline & $\mu \mathrm{g} / \mathrm{kg}$ & 3,7 & 9 & 0 & - & 22 & $<10,2$ & $<6,8$ & $<2$ & - & $<25$ & $<15$ & $<11$ & $<5$ & $<40$ & $<7,5$ & $<4,6$ & $<2-$ & $<15$ \\
\hline Tetracycline & $\mu \mathrm{g} / \mathrm{kg}$ & 1 & 2,6 & 0 & - & 7 & $<5,4$ & $<4,1$ & $<2$ & - & $<15$ & $<9,1$ & $<4,9$ & $<3$ & $<15$ & $<3,1$ & $<2,5$ & $<2-$ & $<10$ \\
\hline Minocycline & $\mu \mathrm{g} / \mathrm{kg}$ & $<30$ & $<9,0$ & $<20$ & - & $<40$ & $<17$ & $<10$ & $<5$ & - & $<40$ & $<25,5$ & $<14$ & $<10$ & $<50$ & $<12,4$ & $<11$ & $<1$ & $<40$ \\
\hline Methacycline & $\mu \mathrm{g} / \mathrm{kg}$ & $<22$ & $<13$ & $<10$ & - & $<40$ & $<11,8$ & $<8,1$ & $<3$ & - & $<30$ & $<19$ & $<15$ & $<5$ & $<50$ & $<5,9$ & $<4,3$ & $<2$ & $<15$ \\
\hline Sulfathiazol & $\mu \mathrm{g} / \mathrm{kg}$ & $<4$ & $<1,3$ & $<2$ & - & $<5$ & $<3,1$ & $<2,8$ & $<1$ & - & $<10$ & $<4$ & $<2,67$ & $<1$ & $<10$ & $<1,4$ & $<1,3$ & & $<5$ \\
\hline
\end{tabular}




\begin{tabular}{|c|c|c|c|c|c|c|c|c|c|c|c|c|c|c|c|c|c|c|c|c|}
\hline Sulfapyridine & $\mu \mathrm{g} / \mathrm{kg}$ & $<1,4$ & $<0,79$ & $<1$ & - & $<3$ & $<1,7$ & $<1,2$ & $<1-$ & $<5$ & $<1,6$ & $<0,70$ & $<1$ & - & $<3$ & $<1,2$ & $<0,63$ & $<1$ & - & $<3$ \\
\hline Sulfamerazine & $\mu \mathrm{g} / \mathrm{kg}$ & $<1,1$ & $<0,38$ & $<1$ & - & $<2$ & $<1$ & $<0$ & $<1-$ & $<1$ & $<1,4$ & $<1,3$ & $<1$ & - & $<5$ & $<1$ & $<0$ & $<1$ & - & $<1$ \\
\hline Sulfamoxol & $\mu \mathrm{g} / \mathrm{kg}$ & $<1,4$ & $<0,53$ & $<1$ & - & $<2$ & $<1,5$ & $<0,71$ & $<1-$ & $<3$ & $<1,4$ & $<0,70$ & $<1$ & - & $<3$ & $<1,2$ & $<0,42$ & $<1$ & - & $<2$ \\
\hline Sulfamethizol & $\mu \mathrm{g} / \mathrm{kg}$ & $<2$ & $<1,53$ & $<1$ & - & $<5$ & $<1,4$ & $<0,52$ & $<1-$ & $<2$ & $<2,3$ & $<2,8$ & $<1$ & - & $<10$ & $<1$ & $<0$ & $<1$ & - & $<1$ \\
\hline $\begin{array}{l}\text { Sulfamethoxypyri } \\
\text { dazine }\end{array}$ & $\mu \mathrm{g} / \mathrm{kg}$ & $<1$ & $<0$ & $<1$ & - & $<1$ & $<1$ & $<0$ & $<1-$ & $<1$ & $<1,2$ & $<0,63$ & $<1$ & - & $<3$ & $<1$ & $<0$ & $<1$ & - & $<1$ \\
\hline $\begin{array}{l}\text { Sulfamonomethox } \\
\text { ine }\end{array}$ & $\mu \mathrm{g} / \mathrm{kg}$ & $<2,3$ & $<1,5$ & $<1$ & - & $<5$ & $<1,4$ & $<0,52$ & $<1-$ & $<2$ & $<2,1$ & $<1,2$ & $<1$ & - & $<5$ & $<1,1$ & $<0,32$ & $<1$ & - & $<2$ \\
\hline $\begin{array}{l}\text { Sulfachloorpyrida } \\
\text { zine }\end{array}$ & $\mu \mathrm{g} / \mathrm{kg}$ & $<2,7$ & $<1,6$ & $<1$ & - & $<5$ & $<2,4$ & $<1,17$ & $<1-$ & $<5$ & $<3,5$ & $<2,5$ & $<1$ & - & $<10$ & $<1,2$ & $<0,63$ & $<1$ & - & $<3$ \\
\hline Sulfadoxine & $\mu \mathrm{g} / \mathrm{kg}$ & $<1,1$ & $<0,38$ & $<1$ & - & $<2$ & $<1$ & $<0$ & $<1-$ & $<1$ & $<1,1$ & $<0,32$ & $<1$ & - & $<2$ & $<1$ & $<0$ & $<1$ & - & $<1$ \\
\hline Sulfamethoxazol & $\mu \mathrm{g} / \mathrm{kg}$ & $<1,4$ & $<0,53$ & $<1$ & - & $<2$ & 0,8 & 2,5 & $0-$ & 8 & 2,3 & 4,1 & 0 & - & 11 & 0,1 & 0,32 & 0 & - & 1 \\
\hline Sulfisoxazol & $\mu \mathrm{g} / \mathrm{kg}$ & $<2,4$ & $<1,4$ & $<1$ & - & $<5$ & $<1,6$ & $<0,70$ & $<1-$ & $<3$ & $<2$ & $<1,3$ & $<1$ & - & $<5$ & $<1,1$ & $<0,32$ & $<1$ & - & $<2$ \\
\hline Sulfadimethoxine & $\mu \mathrm{g} / \mathrm{kg}$ & $<1,3$ & $<0,49$ & $<1$ & - & $<2$ & $<1$ & $<0$ & $<1-$ & $<1$ & $<1,4$ & $<0,7$ & $<1$ & - & $<3$ & $<1$ & $<0$ & $<1$ & - & $<1$ \\
\hline Sulfaquinoxaline & $\mu \mathrm{g} / \mathrm{kg}$ & $<3,6$ & $<3,1$ & $<1$ & - & $<10$ & $<2,1$ & $<1,2$ & $<1-$ & $<5$ & $<3,7$ & $<4,1$ & $<1$ & - & $<15$ & $<1,2$ & $<0,42$ & $<1$ & - & $<2$ \\
\hline Sulfacetamide & $\mu \mathrm{g} / \mathrm{kg}$ & $<1,1$ & $<0,38$ & $<1$ & - & $<2$ & $<1,4$ & $<1,3$ & $<1-$ & $<5$ & $<1,9$ & $<2,8$ & $<1$ & - & $<10$ & $<1$ & $<0$ & $<1$ & - & $<1$ \\
\hline Sulfaphenazol & $\mu \mathrm{g} / \mathrm{kg}$ & $<12$ & $<6,36$ & $<5$ & - & $<25$ & $<8,3$ & $<3,6$ & $<3-$ & $<15$ & $<13$ & $<9,8$ & $<5$ & - & $<40$ & $<4,6$ & $<4,6$ & $<1$ & - & $<10$ \\
\hline Dapson & $\mu \mathrm{g} / \mathrm{kg}$ & $<1,1$ & $<0,38$ & $<1$ & - & $<2$ & $<1$ & $<0$ & $<1-$ & $<1$ & $<1,6$ & $<1,3$ & $<1$ & - & $<5$ & $<1$ & $<0$ & $<1$ & - & $<1$ \\
\hline Marbofloxacine & $\mu \mathrm{g} / \mathrm{kg}$ & $<7,8$ & $<6,2$ & $<2$ & - & $<20$ & $<4,4$ & $<5,7$ & $<1-$ & $<20$ & $<4,7$ & $<3,0$ & $<2$ & - & $<10$ & 0,1 & 0,32 & 0 & - & 1 \\
\hline Norfloxacine & $\mu \mathrm{g} / \mathrm{kg}$ & $<21$ & $<11$ & $<10$ & - & $<40$ & $<12,5$ & $<10$ & $<2-$ & $<40$ & $<16$ & $<11$ & $<5$ & - & $<40$ & $<3,2$ & $<4,2$ & $<1$ & - & $<15$ \\
\hline Danofloxacine & $\mu \mathrm{g} / \mathrm{kg}$ & $<16$ & $<12$ & $<5$ & - & $<40$ & $<10,8$ & $<17$ & $<1-$ & $<60$ & $<11,7$ & $<7,5$ & $<2$ & - & $<25$ & $<2,4$ & $<4,4$ & $<1$ & - & $<15$ \\
\hline Sarafloxacine & $\mu \mathrm{g} / \mathrm{kg}$ & $<20$ & $<10$ & $<10$ & - & $<40$ & $<9,9$ & $<11$ & $<3-$ & $<40$ & $<15,8$ & $<8,1$ & $<3$ & - & $<30$ & $<5,9$ & $<6,0$ & $<1$ & - & $<20$ \\
\hline Difloxacine & $\mu \mathrm{g} / \mathrm{kg}$ & $<11$ & $<8,5$ & $<5$ & - & $<25$ & $<7,3$ & $<11$ & $<2-$ & $<40$ & $<11,5$ & $<7,7$ & $<2$ & - & $<30$ & $<1,9$ & $<2,8$ & $<1$ & - & $<10$ \\
\hline Oxolinezuur & $\mu \mathrm{g} / \mathrm{kg}$ & $<7$ & $<4,7$ & $<3$ & - & $<15$ & $<3,7$ & $<2,5$ & $<2-$ & $<10$ & $<5,1$ & $<2,8$ & $<2$ & - & $<10$ & $<1,5$ & $<1,3$ & $<1$ & - & $<5$ \\
\hline Nalidixinezuur & $\mu \mathrm{g} / \mathrm{kg}$ & $<8$ & $<4,7$ & $<2$ & - & $<15$ & $<4,9$ & $<3,7$ & $<1-$ & $<10$ & $<5,7$ & $<5,0$ & $<1$ & - & $<15$ & $<1,1$ & $<0,32$ & $<1$ & - & $<2$ \\
\hline $\begin{array}{l}\text { Levofloxacin/oflox } \\
\text { acin }\end{array}$ & $\mu \mathrm{g} / \mathrm{kg}$ & $<8$ & $<4,7$ & $<5$ & - & $<15$ & $<5,3$ & $<3,6$ & $<2-$ & $<15$ & $<6,3$ & $<4,1$ & $<2$ & - & $<15$ & $<3,9$ & $<1,8$ & $<1$ & - & $<5$ \\
\hline Trovafloxacin & $\mu \mathrm{g} / \mathrm{kg}$ & $<4,8$ & $<2,7$ & $<2$ & - & $<10$ & $<2,8$ & $<4,3$ & $<1-$ & $<15$ & $<3,6$ & $<2,8$ & $<1$ & - & $<10$ & $<1,5$ & $<0,71$ & $<1$ & - & $<3$ \\
\hline Erythromycine & $\mu \mathrm{g} / \mathrm{kg}$ & $<24$ & $<16$ & $<3$ & - & $<50$ & $<17,1$ & $<11$ & $<3-$ & $<40$ & $<28$ & $<21$ & $<5$ & - & $<70$ & $<2,9$ & $<3,0$ & $<1$ & - & $<10$ \\
\hline Tylosine & $\mu \mathrm{g} / \mathrm{kg}$ & 4,7 & 2,5 & 0 & - & 8 & 1,7 & 5,4 & $0-$ & 17 & 0,7 & 1,5 & 0 & - & 4 & 0,3 & 0,95 & 0 & - & 3 \\
\hline Josamycine & $\mu \mathrm{g} / \mathrm{kg}$ & $<2,4$ & $<3,3$ & $<1$ & - & $<10$ & $<5,5$ & $<12$ & $<1-$ & $<40$ & $<7,1$ & $<15$ & $<1$ & - & $<50$ & $<1,1$ & $<0,32$ & $<1$ & - & $<2$ \\
\hline Spiramycine & $\mu \mathrm{g} / \mathrm{kg}$ & $<9,3$ & $<5,3$ & $<5$ & - & $<20$ & $<7,1$ & $<3$ & $<3-$ & $<10$ & $<11$ & $<4,6$ & $<5$ & - & $<20$ & $<39,8$ & $<51$ & $<1$ & - & $<150$ \\
\hline
\end{tabular}




\begin{tabular}{|c|c|c|c|c|c|c|c|c|c|c|c|c|c|c|c|c|c|c|c|c|}
\hline Neospiramycine 1 & $\mu \mathrm{g} / \mathrm{kg}$ & $<8$ & $<9,7$ & $<3$ & & $<30$ & $<5,8$ & $<3,1$ & $<2$ & - & $<10$ & $<7,6$ & $<5,7$ & $<2$ & - & $<20$ & $<11,4$ & $<9,0$ & $<3-$ & $<25$ \\
\hline Tiamulin & $\mu \mathrm{g} / \mathrm{kg}$ & 12 & 27 & 0 & - & 73 & 19 & 58 & 0 & - & 183 & 1,1 & 1,9 & 0 & - & 5 & 0,8 & 2,5 & $0-$ & 8 \\
\hline Tulathromycine & $\mu \mathrm{g} / \mathrm{kg}$ & $<11$ & $<26$ & $<1$ & - & $<70$ & $<4,1$ & $<4,2$ & $<1$ & - & $<10$ & $<4$ & $<4,8$ & $<1$ & - & $<15$ & $<1$ & $<0$ & $<1-$ & $<1$ \\
\hline Pirlimycine & $\mu \mathrm{g} / \mathrm{kg}$ & $<2$ & $<0,56$ & $<1$ & - & $<3$ & $<1,9$ & $<1,2$ & $<1$ & - & $<5$ & $<2,7$ & $<1,1$ & $<1$ & - & $<5$ & $<4,5$ & $<7,4$ & $<1-$ & $<25$ \\
\hline Valnemulin & $\mu \mathrm{g} / \mathrm{kg}$ & $<2,4$ & $<1,8$ & $<1$ & - & $<5$ & $<2$ & $<1,7$ & $<1$ & - & $<5$ & $<2,1$ & $<1,7$ & $<1$ & - & $<5$ & 0,2 & 0,63 & $0-$ & 2 \\
\hline Tylvalosine & $\mu \mathrm{g} / \mathrm{kg}$ & $<2,7$ & $<1,7$ & $<1$ & - & $<5$ & $<1,5$ & $<0,85$ & $<1$ & - & $<3$ & $<3,6$ & $<3,6$ & $<1$ & - & $<10$ & $<3$ & $<2,7$ & $<1-$ & $<10$ \\
\hline Natamycin & $\mu \mathrm{g} / \mathrm{kg}$ & $<12$ & $<13$ & $<1$ & - & $<40$ & $<8,8$ & $<7,0$ & $<1$ & - & $<20$ & $<12$ & $<11$ & $<2$ & - & $<40$ & $<4,8$ & $<4,5$ & $<1 \quad-$ & $<10$ \\
\hline Gamithromycine & $\mu \mathrm{g} / \mathrm{kg}$ & $<2,1$ & $<1,6$ & $<1$ & - & $<5$ & $<2,1$ & $<1,4$ & $<1$ & - & $<5$ & $<2,8$ & $<2,8$ & $<1$ & - & $<10$ & $<16$ & $<36$ & $<1-$ & $<90$ \\
\hline Tildipirosine & $\mu \mathrm{g} / \mathrm{kg}$ & $<7,3$ & $<8,3$ & $<1$ & - & $<25$ & $<5,3$ & $<12$ & $<1$ & - & $<40$ & $<1,8$ & $<1,3$ & $<1$ & - & $<5$ & $<7$ & $<12$ & $<1-$ & $<25$ \\
\hline Vancomycine & $\mu \mathrm{g} / \mathrm{kg}$ & $<14$ & $<8,3$ & $<3$ & - & $<25$ & $<14,3$ & $<11$ & $<2$ & - & $<30$ & $<25,8$ & $<23$ & $<3$ & - & $<80$ & $<4,6$ & $<4$ & $<1-$ & $<10$ \\
\hline Azithromycine & $\mu \mathrm{g} / \mathrm{kg}$ & $<2,6$ & $<1,8$ & $<1$ & - & $<5$ & $<2,1$ & $<1,67$ & $<1$ & - & $<5$ & $<2,7$ & $<2,0$ & $<1$ & - & $<5$ & $<1,8$ & $<1,7$ & $<1-$ & $<5$ \\
\hline Clarithromycine & $\mu \mathrm{g} / \mathrm{kg}$ & $<2,6$ & $<3,3$ & $<1$ & - & $<10$ & $<2,7$ & $<2,9$ & $<1$ & - & $<10$ & $<3,6$ & $<3,6$ & $<1$ & - & $<10$ & $<1$ & $<0$ & $<1-$ & $<1$ \\
\hline
\end{tabular}




\section{Analyseresultaten MBR-UF}

\begin{tabular}{|c|c|c|c|c|c|c|c|c|c|c|c|c|c|c|c|c|c|c|c|c|}
\hline \multirow[b]{2}{*}{ Parameter } & \multirow[b]{2}{*}{ Eenheid } & \multicolumn{4}{|c|}{ Ruwe mest } & \multicolumn{5}{|c|}{ Invoer MBR } & \multicolumn{5}{|c|}{ Invoer UF } & \multicolumn{5}{|c|}{ Effluent } \\
\hline & & Gem. & SD & Min & $\operatorname{Max}$ & Gem. & SD & Min & - & $\operatorname{Max}$ & Gem. & SD & Min & - & Max & Gem. & SD & Min & - & $\operatorname{Max}$ \\
\hline \multicolumn{21}{|c|}{ Algemene chemische parameters } \\
\hline BZV & $\mathrm{mg} / \mathrm{l}$ & 8424 & 2199 & 6240 & - 10800 & 4218 & 1556 & 2410 & - & 6570 & 1818 & 240 & 1590 & - & 2160 & 8 & 7,3 & 3 & - & 21 \\
\hline CZV & $\mathrm{mg} / \mathrm{l}$ & 65140 & 12328 & 54400 & - 85400 & 11290 & 2626 & 9530 & - & 15800 & 18560 & 1905 & 17100 & - & 21900 & 744 & 174 & 480 & - & 920 \\
\hline Onopgeloste stoffen & $\mathrm{mg} / \mathrm{l}$ & NA & NA & 0 & 0 & 1500 & NA & 1500 & - & 1500 & 19000 & NA & 19000 & - & 19000 & 7,7 & 9,8 & 0 & - & 24 \\
\hline P-totaal & $\mathrm{mg} / \mathrm{kg}$ & 1255 & 86 & 1157 & 1315 & 133 & 17 & 122 & - & 153 & 493 & 40 & 454 & - & 534 & 5,3 & 3,5 & 2,2 & - & 9,2 \\
\hline P-PO4 & $\mathrm{mg} / \mathrm{kg}$ & 238 & 26 & 208 & 254 & 101 & 14 & 92 & - & 117 & 51 & 23 & 26 & - & 72 & 8,3 & 5 & 3,8 & - & 14 \\
\hline $\mathrm{N}$-totaal & $\mathrm{mg} / \mathrm{kg}$ & 5027 & 736 & 4180 & 5518 & 3222 & 345 & 2954 & - & 3612 & 1271 & 89 & 1172 & - & 1344 & 51 & 27 & 29 & - & 82 \\
\hline $\mathrm{N}-\mathrm{NH} 4$ & $\mathrm{mg} / \mathrm{kg}$ & 3040 & 326 & 2674 & 3297 & 2766 & 324 & 2499 & - & 3126 & 91 & 82 & 14 & - & 176 & 21 & 10 & 14 & - & 32 \\
\hline $\mathrm{NO} 2-\mathrm{N}+\mathrm{NO} 3-\mathrm{N}$ & $\mathrm{mg} / \mathrm{kg}$ & 2,6 & 4,4 & 0 & 7,7 & 2,1 & 2,7 & 0 & - & 5,2 & 29 & 42 & 2,3 & - & 78 & 10 & 14 & 0 & - & 26 \\
\hline $\mathrm{pH}$ & & 7,8 & 0,17 & 7,6 & 8 & 8 & 0,2 & 7,8 & - & 8,2 & 7,9 & 0,23 & 7,7 & - & 8,1 & 8,6 & 0,16 & 8,4 & - & 8,7 \\
\hline EC & $\mathrm{mS}$ & 23 & 3,4 & 20 & 26 & 28 & 2 & 26 & - & 30 & 11 & 0,35 & 11 & - & 12 & 8,4 & 3 & 6 & - & 12 \\
\hline $\mathrm{Cl}-$ & $\mathrm{mg} / \mathrm{kg}$ & 1970 & 896 & 1186 & 3500 & 1617 & 141 & 1500 & - & 1829 & 1862 & 151 & 1734 & - & 2100 & 1588 & 606 & 862 & - & 2100 \\
\hline S & $\mathrm{mg} / \mathrm{kg}$ & 777 & 104 & 660 & 860 & 250 & 46 & 210 & - & 300 & 430 & 82 & 340 & - & 500 & 103 & 5,8 & 100 & - & 110 \\
\hline K & $\mathrm{mg} / \mathrm{kg}$ & 3600 & 700 & 2900 & 4300 & 3367 & 231 & 3100 & - & 3500 & 3267 & 208 & 3100 & - & 3500 & 2033 & 850 & 1400 & - & 3000 \\
\hline \multicolumn{21}{|l|}{ Zware metalen } \\
\hline $\mathrm{Cd}$ & $\mathrm{mg} / \mathrm{kg}$ & 0,03 & 0 & 0,03 & 0,03 & $<0,027$ & $<0$ & $<0,027$ & - & $<0,027$ & $<0,027$ & $<0$ & $<0,027$ & - & $<0,027$ & $<0,027$ & $<0$ & $<0,027$ & - & $<0,027$ \\
\hline $\mathrm{Hg}$ & $\mathrm{mg} / \mathrm{kg}$ & $<0,012$ & $<0,00$ & $<0,012$ & $-<0,012$ & $<0,012$ & $<0,00$ & $<0,012$ & - & $<0,012$ & $<0,012$ & $<0,00$ & $<0,012$ & - & $<0,012$ & $<0,012$ & $<0$ & $<0,012$ & - & $<0,012$ \\
\hline $\mathrm{Pb}$ & $\mathrm{mg} / \mathrm{kg}$ & 0,08 & 0,02 & 0,07 & 0,1 & $<0,013$ & $<0$ & $<0,013$ & - & $<0,013$ & $<0,013$ & $<0$ & $<0,013$ & - & $<0,013$ & $<0,013$ & $<0$ & $<0,013$ & - & $<0,013$ \\
\hline As & $\mathrm{mg} / \mathrm{kg}$ & $<0,11$ & $<0$ & $<0,11$ & $-\quad<0,11$ & $<0,11$ & $<0$ & $<0,11$ & - & $<0,11$ & $<0,11$ & $<0$ & $<0,11$ & - & $<0,11$ & $<0,11$ & $<0$ & $<0,11$ & - & $<0,11$ \\
\hline $\mathrm{Cr}$ & $\mathrm{mg} / \mathrm{kg}$ & 0,58 & 0,1 & 0,46 & 0,65 & 0,03 & 0,04 & 0 & - & 0,08 & 0,41 & 0,09 & 0,32 & - & 0,49 & $<0,074$ & $<0$ & $<0,074$ & - & $<0,074$ \\
\hline $\mathrm{Ni}$ & $\mathrm{mg} / \mathrm{kg}$ & 0,64 & 0,06 & 0,59 & 0,7 & 0,25 & 0,04 & 0,21 & - & 0,28 & 0,61 & 0,06 & 0,58 & - & 0,68 & 0,04 & 0,06 & 0 & - & 0,11 \\
\hline $\mathrm{Cu}$ & $\mathrm{mg} / \mathrm{kg}$ & 12 & 0,58 & 12 & 13 & $<0,57$ & $<0$ & $<0,57$ & - & $<0,57$ & 1 & 0,28 & 0,71 & - & 1,2 & $<0,57$ & $<0$ & $<0,57$ & - & $<0,57$ \\
\hline $\mathrm{Zn}$ & $\mathrm{mg} / \mathrm{kg}$ & 46 & 2,6 & 44 & 49 & 1,2 & 1,2 & 0 & - & 2,3 & 3,8 & 1,4 & 2,2 & - & 4,9 & $<1,1$ & $<0$ & $<1,1$ & - & $<1,1$ \\
\hline $\mathrm{Ba}$ & $\mathrm{mg} / \mathrm{kg}$ & 2,4 & 0,21 & 2,2 & 2,6 & 0,07 & 0,12 & 0 & - & 0,21 & 0,53 & 0,24 & 0,26 & - & 0,7 & $<0,16$ & $<0$ & $<0,16$ & - & $<0,16$ \\
\hline
\end{tabular}




\begin{tabular}{|c|c|c|c|c|c|c|c|c|c|c|c|c|c|c|c|c|c|c|c|}
\hline V & $\mathrm{mg} / \mathrm{kg}$ & 0,32 & NA & 0,32 & 0,32 & $<0,28$ & NA & $<0,28$ & - & $<0,28$ & 0,54 & NA & 0,54 & - & 0,54 & $<0,28$ & NA & $<0,28$ & $<0,28$ \\
\hline U & $\mathrm{mg} / \mathrm{kg}$ & $<0,062$ & NA & $<0,062$ & $-<0,062$ & $<0,062$ & NA & $<0,062$ & - & $<0,062$ & $<0,062$ & NA & $<0,062$ & - & $<0,062$ & $<0,062$ & NA & $<0,062$ & $-\quad<0,062$ \\
\hline Co & $\mathrm{mg} / \mathrm{kg}$ & 0,15 & 0,02 & 0,13 & 0,16 & NA & NA & 0 & - & 0 & NA & NA & 0 & 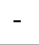 & 0 & 0,02 & 0 & 0,02 & 0,03 \\
\hline $\mathrm{Se}$ & $\mathrm{mg} / \mathrm{kg}$ & 0,3 & 0,02 & 0,28 & 0,32 & NA & NA & 0 & - & 0 & NA & NA & 0 & - & 0 & $<0,032$ & $<0$ & $<0,032$ & $-\quad<0,032$ \\
\hline
\end{tabular}

\section{Hormoonstoffen}

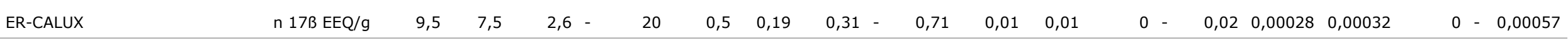

\section{Antibiotica}

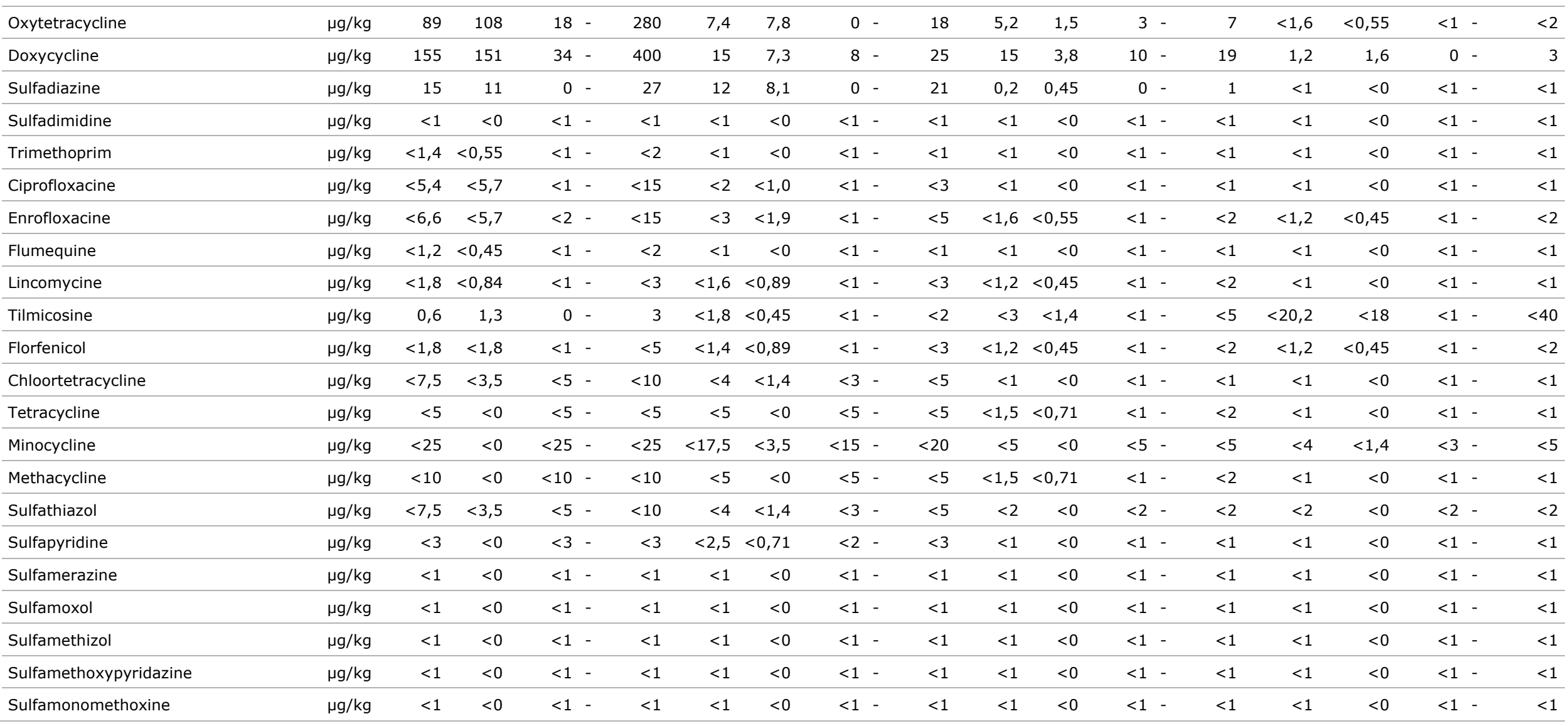




\begin{tabular}{|c|c|c|c|c|c|c|c|c|c|c|c|c|c|c|c|c|c|c|c|c|}
\hline Sulfachloorpyridazine & $\mu \mathrm{g} / \mathrm{kg}$ & $<2$ & $<0$ & $<2-$ & $<2$ & $<2$ & $<0$ & $<2$ & - & $<2$ & $<1$ & $<0$ & $<1$ & - & $<1$ & $<1$ & $<0$ & $<1$ & - & $<1$ \\
\hline Sulfadoxine & $\mu \mathrm{g} / \mathrm{kg}$ & $<1$ & $<0$ & $<1-$ & $<1$ & $<1$ & $<0$ & $<1$ & - & $<1$ & $<1$ & $<0$ & $<1$ & - & $<1$ & $<1$ & $<0$ & $<1$ & - & $<1$ \\
\hline Sulfamethoxazol & $\mu \mathrm{g} / \mathrm{kg}$ & $<1$ & $<0$ & $<1-$ & $<1$ & $<1$ & $<0$ & $<1$ & - & $<1$ & $<1$ & $<0$ & $<1$ & - & $<1$ & $<1$ & $<0$ & $<1$ & - & $<1$ \\
\hline Sulfisoxazol & $\mu g / \mathrm{kg}$ & $<2$ & $<0$ & $<2-$ & $<2$ & $<2$ & $<0$ & $<2$ & - & $<2$ & $<1$ & $<0$ & $<1$ & - & $<1$ & $<1$ & $<0$ & $<1$ & - & $<1$ \\
\hline Sulfadimethoxine & $\mu \mathrm{g} / \mathrm{kg}$ & $<1$ & $<0$ & $<1-$ & $<1$ & $<1$ & $<0$ & $<1$ & - & $<1$ & $<1$ & $<0$ & $<1$ & - & $<1$ & $<1$ & $<0$ & $<1$ & - & $<1$ \\
\hline Sulfaquinoxaline & $\mu \mathrm{g} / \mathrm{kg}$ & $<2$ & $<0$ & $<2-$ & $<2$ & $<1$ & $<0$ & $<1$ & - & $<1$ & $<1$ & $<0$ & $<1$ & - & $<1$ & $<1$ & $<0$ & $<1$ & - & $<1$ \\
\hline Sulfacetamide & $\mu \mathrm{g} / \mathrm{kg}$ & $<1$ & $<0$ & $<1-$ & $<1$ & $<1$ & $<0$ & $<1$ & - & $<1$ & $<1$ & $<0$ & $<1$ & - & $<1$ & $<1$ & $<0$ & $<1$ & - & $<1$ \\
\hline Sulfaphenazol & $\mu \mathrm{g} / \mathrm{kg}$ & $<10$ & $<0$ & $<10-$ & $<10$ & $<7,5$ & $<3,5$ & $<5$ & - & $<10$ & $<2$ & $<0$ & $<2$ & - & $<2$ & $<2$ & $<0$ & $<2$ & - & $<2$ \\
\hline Dapson & $\mu g / \mathrm{kg}$ & $<1$ & $<0$ & $<1 \quad-$ & $<1$ & $<1$ & $<0$ & $<1$ & - & $<1$ & $<1$ & $<0$ & $<1$ & - & $<1$ & $<1$ & $<0$ & $<1$ & - & $<1$ \\
\hline Marbofloxacine & $\mu \mathrm{g} / \mathrm{kg}$ & $<7,5$ & $<3,5$ & $<5-$ & $<10$ & $<4$ & $<1,4$ & $<3$ & - & $<5$ & $<1,5$ & $<0,71$ & $<1$ & - & $<2$ & $<1$ & $<0$ & $<1$ & - & $<1$ \\
\hline Norfloxacine & $\mu g / \mathrm{kg}$ & $<12,5$ & $<3,5$ & $<10-$ & $<15$ & $<7,5$ & $<3,5$ & $<5$ & - & $<10$ & $<2$ & $<0$ & $<2$ & - & $<2$ & $<1,5$ & $<0,71$ & $<1$ & - & $<2$ \\
\hline Danofloxacine & $\mu \mathrm{g} / \mathrm{kg}$ & $<12,5$ & $<3,5$ & $<10 \quad-$ & $<15$ & $<5$ & $<0$ & $<5$ & - & $<5$ & $<2$ & $<0$ & $<2$ & - & $<2$ & $<1,5$ & $<0,71$ & $<1$ & - & $<2$ \\
\hline Sarafloxacine & $\mu \mathrm{g} / \mathrm{kg}$ & $<25$ & $<7,1$ & $<20-$ & $<30$ & $<10$ & $<0$ & $<10$ & - & $<10$ & $<5$ & $<0$ & $<5$ & - & $<5$ & $<5$ & $<0$ & & - & $<5$ \\
\hline Difloxacine & $\mu \mathrm{g} / \mathrm{kg}$ & $<10$ & $<0$ & $<10-$ & $<10$ & $<3$ & $<0$ & $<3$ & - & $<3$ & $<1,5$ & $<0,71$ & $<1$ & - & $<2$ & $<1$ & $<0$ & $<1$ & - & $<1$ \\
\hline Oxolinezuur & $\mu \mathrm{g} / \mathrm{kg}$ & $<4$ & $<1,4$ & $<3-$ & $<5$ & $<3$ & $<0$ & $<3$ & - & $<3$ & $<1$ & $<0$ & $<1$ & - & $<1$ & $<1$ & $<0$ & $<1$ & - & $<1$ \\
\hline Nalidixinezuur & $\mu g / \mathrm{kg}$ & $<2$ & $<0$ & $<2-$ & $<2$ & $<2$ & $<0$ & $<2$ & - & $<2$ & $<1$ & $<0$ & $<1$ & - & $<1$ & $<1$ & $<0$ & $<1$ & - & $<1$ \\
\hline Levofloxacin/ofloxacin & $\mu g / \mathrm{kg}$ & $<5$ & $<0$ & $<5-$ & $<5$ & $<5$ & $<0$ & $<5$ & - & $<5$ & $<5$ & $<0$ & $<5$ & - & $<5$ & $<5$ & $<0$ & $<5$ & - & $<5$ \\
\hline Trovafloxacin & $\mu g / k g$ & $<4$ & $<1,4$ & $<3-$ & $<5$ & $<1,5$ & $<0,71$ & $<1$ & - & $<2$ & $<1$ & $<0$ & $<1$ & - & $<1$ & $<1$ & $<0$ & $<1$ & - & $<1$ \\
\hline Erythromycine & $\mu \mathrm{g} / \mathrm{kg}$ & $<5$ & $<0$ & $<5-$ & $<5$ & $<5$ & $<0$ & $<5$ & - & $<5$ & $<1$ & $<0$ & $<1$ & - & $<1$ & $<1$ & $<0$ & $<1$ & - & $<1$ \\
\hline Tylosine & $\mu \mathrm{g} / \mathrm{kg}$ & 5,5 & 0,71 & $5-$ & 6 & $<2,5$ & $<0,71$ & $<2$ & - & $<3$ & $<1,5$ & $<0,71$ & $<1$ & - & $<2$ & $<2$ & $<0$ & $<2$ & - & $<2$ \\
\hline Josamycine & $\mu g / \mathrm{kg}$ & $<1$ & $<0$ & $<1 \quad-$ & $<1$ & $<1$ & $<0$ & $<1$ & - & $<1$ & $<1$ & $<0$ & $<1$ & - & $<1$ & $<1$ & $<0$ & $<1$ & - & $<1$ \\
\hline Spiramycine & $\mu g / \mathrm{kg}$ & $<5$ & $<0$ & $<5-$ & $<5$ & $<5$ & $<0$ & $<5$ & - & $<5$ & $<1,5$ & $<0,71$ & $<1$ & - & $<2$ & $<2$ & $<0$ & $<2$ & - & $<2$ \\
\hline Neospiramycine 1 & $\mu g / \mathrm{kg}$ & $<2,5$ & $<0,71$ & $<2 \quad-$ & $<3$ & $<2,5$ & $<0,71$ & $<2$ & - & $<3$ & $<2,5$ & $<0,71$ & $<2$ & - & $<3$ & $<3,5$ & $<0,71$ & $<3$ & - & $<4$ \\
\hline Tiamulin & $\mu \mathrm{g} / \mathrm{kg}$ & $<2$ & $<0$ & $<2 \quad-$ & $<2$ & $<2$ & $<0$ & $<2$ & - & $<2$ & $<1$ & $<0$ & $<1$ & - & $<1$ & $<1$ & $<0$ & $<1$ & - & $<1$ \\
\hline Tulathromycine & $\mu \mathrm{g} / \mathrm{kg}$ & $<1$ & $<0$ & $<1-$ & $<1$ & $<1$ & $<0$ & $<1$ & - & $<1$ & $<1$ & $<0$ & $<1$ & - & $<1$ & $<2$ & $<1,4$ & $<1$ & - & $<3$ \\
\hline Pirlimycine & $\mu g / \mathrm{kg}$ & $<1$ & $<0$ & $<1 \quad-$ & $<1$ & $<1$ & $<0$ & $<1$ & - & $<1$ & $<1$ & $<0$ & $<1$ & - & $<1$ & $<1$ & $<0$ & $<1$ & - & $<1$ \\
\hline Valnemulin & $\mu g / k g$ & $<1$ & $<0$ & $<1 \quad-$ & $<1$ & $<1$ & $<0$ & $<1$ & - & $<1$ & $<1$ & $<0$ & $<1$ & - & $<1$ & $<1$ & $<0$ & $<1$ & - & $<1$ \\
\hline Tylvalosine & $\mu \mathrm{g} / \mathrm{kg}$ & $<1$ & $<0$ & $<1 \quad-$ & $<1$ & $<1$ & $<0$ & $<1$ & - & $<1$ & $<1$ & $<0$ & $<1$ & - & $<1$ & $<1,5$ & $<0,71$ & $<1$ & - & $<2$ \\
\hline Natamycin & $\mu \mathrm{g} / \mathrm{kg}$ & $<2$ & $<0$ & $<2-$ & $<2$ & $<2$ & $<0$ & $<2$ & - & $<2$ & $<1$ & $<0$ & $<1$ & - & $<1$ & $<1$ & $<0$ & $<1$ & - & $<1$ \\
\hline
\end{tabular}




\begin{tabular}{|c|c|c|c|c|c|c|c|c|c|c|c|c|c|c|c|c|c|c|c|}
\hline Gamithromycine & $\mu \mathrm{g} / \mathrm{kg}$ & $<1$ & $<0$ & $<1-$ & $<1$ & $<1$ & $<0$ & $<1$ & & $<1$ & $<1$ & $<0$ & $<1$ & & $<1$ & $<2$ & $<0$ & $<2-$ & $<2$ \\
\hline Tildipirosine & $\mu g / \mathrm{kg}$ & $<5$ & $<0$ & $<5-$ & $<5$ & $<1$ & $<0$ & $<1$ & - & $<1$ & $<1,5$ & $<0,71$ & $<1$ & - & $<2$ & $<3,5$ & $<2,1$ & $<2-$ & $<5$ \\
\hline Vancomycine & $\mu \mathrm{g} / \mathrm{kg}$ & $<4$ & $<1,4$ & $<3-$ & $<5$ & $<3$ & $<0$ & $<3$ & - & $<3$ & $<1$ & $<0$ & $<1$ & - & $<1$ & $<1$ & $<0$ & $<1 \quad-$ & $<1$ \\
\hline Azithromycine & $\mu g / \mathrm{kg}$ & $<1$ & $<0$ & $<1-$ & $<1$ & $<1$ & $<0$ & $<1$ & - & $<1$ & $<1$ & $<0$ & $<1$ & - & $<1$ & $<1$ & $<0$ & $<1 \quad-$ & $<1$ \\
\hline Clarithromycine & $\mu \mathrm{g} / \mathrm{kg}$ & $<1$ & $<0$ & $<1-$ & $<1$ & $<1$ & $<0$ & $<1$ & - & $<1$ & $<1$ & $<0$ & $<1$ & - & $<1$ & $<1$ & $<0$ & $<1-$ & $<1$ \\
\hline
\end{tabular}




\section{Analyseresultaten Biologische voorzuivering}

\begin{tabular}{|c|c|c|c|c|c|c|c|c|c|c|c|c|c|c|c|c|}
\hline & \multirow[b]{2}{*}{ Eenheid } & \multicolumn{5}{|c|}{ Ruwe mest } & \multicolumn{6}{|c|}{ Invoer Biologie } & \multicolumn{3}{|c|}{ Effluent } & \multirow[b]{2}{*}{$\operatorname{Max}$} \\
\hline & & Mean & SD & Min & & $\operatorname{Max}$ & Mean & SD & Min & & Max & Mean & SD & Min & & \\
\hline \multicolumn{17}{|c|}{ Algemene chemische parameters } \\
\hline BZV & $\mathrm{mg} / \mathrm{l}$ & 12100 & 1707 & 10300 & - & 14800 & 9792 & 3905 & 190 & - & 13300 & 1737 & 4450 & 140 & - & 13600 \\
\hline CZV & $\mathrm{mg} / \mathrm{l}$ & 63080 & 26922 & 41800 & - & 107600 & 25664 & 14284 & 1510 & - & 43100 & 5299 & 9285 & 1570 & - & 30000 \\
\hline Onopgeloste stoffen & $\mathrm{mg} / \mathrm{l}$ & NA & NA & 0 & - & 0 & 1350 & 1061 & 600 & - & 2100 & 1311 & 650 & 670 & - & 2500 \\
\hline P-totaal & $\mathrm{mg} / \mathrm{kg}$ & 527 & 37 & 474 & - & 568 & 194 & 15 & 170 & - & 211 & 31 & 6,1 & 23 & - & 41 \\
\hline P-PO4 & $\mathrm{mg} / \mathrm{kg}$ & 97 & 26 & 61 & - & 124 & 73 & 13 & 54 & - & 90 & 19 & 3,9 & 14 & - & 24 \\
\hline $\mathrm{N}$-totaal & $\mathrm{mg} / \mathrm{kg}$ & 3978 & 214 & 3740 & - & 4399 & 3330 & 343 & 2958 & - & 4057 & 168 & 101 & 82 & - & 413 \\
\hline $\mathrm{N}-\mathrm{NH}_{4}$ & $\mathrm{mg} / \mathrm{kg}$ & 2431 & 222 & 2156 & - & 2770 & 2231 & 199 & 1983 & - & 2626 & 48 & 63 & 16 & - & 215 \\
\hline $\mathrm{NO}_{2}-\mathrm{N}+\mathrm{NO}_{3}-\mathrm{N}$ & $\mathrm{mg} / \mathrm{kg}$ & 5 & 5,4 & 0 & - & 14 & 4,7 & 6,3 & 0 & - & 17 & 28 & 30 & 0 & - & 80 \\
\hline $\mathrm{pH}$ & - & 7,5 & 0,11 & 7,3 & - & 7,7 & 7,7 & 0,05 & 7,6 & - & 7,8 & 8,3 & 0,09 & 8,2 & - & 8,5 \\
\hline EC & $\mathrm{mS}$ & 28 & 1,6 & 26 & - & 31 & 27 & 1,4 & 26 & - & 30 & 14 & 5,3 & 0,16 & - & 18 \\
\hline $\mathrm{Cl}-$ & $\mathrm{mg} / \mathrm{kg}$ & 2294 & 256 & 2020 & - & 2680 & 2050 & 207 & 1837 & - & 2492 & 2133 & 170 & 1949 & - & 2505 \\
\hline $\mathrm{S}$ & $\mathrm{mg} / \mathrm{kg}$ & 330 & 139 & 0 & - & 430 & 262 & 58 & 210 & - & 370 & 200 & 48 & 150 & - & 280 \\
\hline $\mathrm{K}$ & $\mathrm{mg} / \mathrm{kg}$ & 3075 & 1266 & 0 & - & 4000 & 3256 & 332 & 2900 & - & 4000 & 3233 & 346 & 2900 & - & 3900 \\
\hline \multicolumn{17}{|l|}{ Zware metalen } \\
\hline $\mathrm{Cd}$ & $\mathrm{mg} / \mathrm{kg}$ & $<0,03$ & $<0$ & $<0,03$ & - & $<0,03$ & $<0,03$ & $<0$ & $<0,027$ & - & $<0,027$ & $<0,03$ & $<0$ & $<0,027$ & - & $<0,027$ \\
\hline $\mathrm{Hg}$ & $\mathrm{mg} / \mathrm{kg}$ & $<0,01$ & $<0$ & $<0,01$ & - & $<0,01$ & $<0,01$ & $<0,00$ & $<0,012$ & - & $<0,012$ & $<0,01$ & $<0,00$ & $<0,012$ & - & $<0,012$ \\
\hline $\mathrm{Pb}$ & $\mathrm{mg} / \mathrm{kg}$ & 0,02 & 0,01 & 0 & - & 0,03 & 0,01 & 0,01 & 0 & - & 0,03 & $<0,01$ & $<0$ & $<0,013$ & - & $<0,013$ \\
\hline As & $\mathrm{mg} / \mathrm{kg}$ & $<0,11$ & $<0$ & $<0,11$ & - & $<0,11$ & $<0,11$ & $<0$ & $<0,11$ & - & $<0,11$ & $<0,11$ & $<0$ & $<0,11$ & - & $<0,11$ \\
\hline $\mathrm{Cr}$ & $\mathrm{mg} / \mathrm{kg}$ & 0,05 & 0,05 & 0 & - & 0,09 & 0,01 & 0,03 & 0 & - & 0,08 & $<0,07$ & $<0$ & $<0,074$ & - & $<0,074$ \\
\hline $\mathrm{Ni}$ & $\mathrm{mg} / \mathrm{kg}$ & 0,11 & 0,07 & 0 & - & 0,16 & 0,1 & 0,06 & 0 & - & 0,16 & 0,02 & 0,04 & 0 & - & 0,1 \\
\hline $\mathrm{Cu}$ & $\mathrm{mg} / \mathrm{kg}$ & 2,2 & 1,5 & 0 & - & 3,1 & 1,9 & 1,1 & 0 & - & 3,1 & 0,3 & 0,73 & 0 & - & 1,8 \\
\hline $\mathrm{Zn}$ & $\mathrm{mg} / \mathrm{kg}$ & 24 & 15 & 1,2 & - & 33 & 20 & 11 & 0 & - & 32 & 4 & 7,9 & 0 & - & 20 \\
\hline $\mathrm{Ba}$ & $\mathrm{mg} / \mathrm{kg}$ & 0,47 & 0,34 & 0 & - & 0,81 & 0,3 & 0,17 & 0 & - & 0,44 & 0,05 & 0,13 & 0 & - & 0,32 \\
\hline
\end{tabular}




\begin{tabular}{|c|c|c|c|c|c|c|c|c|c|c|c|c|c|c|c|c|}
\hline v & $\mathrm{mg} / \mathrm{kg}$ & $<0,28$ & $<0$ & $<0,28$ & - & $<0,28$ & $<0,28$ & $<0$ & $<0,28$ & - & $<0,28$ & $<0,28$ & $<0$ & $<0,28$ & - & $<0,28$ \\
\hline u & $\mathrm{mg} / \mathrm{kg}$ & $<0,06$ & $<0$ & $<0,06$ & - & $<0,06$ & $<0,06$ & $<0$ & $<0,062$ & - & $<0,062$ & $<0,06$ & $<0$ & $<0,062$ & - & $<0,062$ \\
\hline Co & $\mathrm{mg} / \mathrm{kg}$ & NA & NA & 0 & - & 0 & NA & NA & 0 & - & 0 & NA & NA & 0 & - & 0 \\
\hline $\mathrm{Se}$ & $\mathrm{mg} / \mathrm{kg}$ & NA & NA & 0 & - & 0 & NA & NA & 0 & - & 0 & NA & NA & 0 & - & 0 \\
\hline \multicolumn{17}{|l|}{ Hormoonstoffen } \\
\hline ER-CALUX & $\mathrm{n} E E Q / g$ & 0,37 & 0,11 & 0,2 & - & 0,44 & 0,16 & 0,09 & 0,09 & - & 0,28 & 0,00118 & 0 & 0 & - & 0 \\
\hline \multicolumn{17}{|l|}{ Antibiotica } \\
\hline Oxytetracycline & $\mu \mathrm{g} / \mathrm{kg}$ & 1954 & 1019 & 1000 & - & 5000 & 1463 & 438 & 148 & - & 2000 & 479 & 928 & 44 & - & 3200 \\
\hline Doxycycline & $\mu \mathrm{g} / \mathrm{kg}$ & 1379 & 378 & 810 & - & 2100 & 1703 & 1906 & 67 & - & 8370 & 312 & 696 & 19 & - & 2300 \\
\hline Sulfadiazine & $\mu \mathrm{g} / \mathrm{kg}$ & 61 & 55 & 7 & - & 200 & 81 & 71 & 0 & - & 230 & 5,3 & 13 & 0 & - & 41 \\
\hline Sulfadimidine & $\mu \mathrm{g} / \mathrm{kg}$ & 43 & 94 & 2 & - & 340 & 14 & 17 & 0 & - & 60 & 2,8 & 10 & 0 & - & 39 \\
\hline Trimethoprim & $\mu \mathrm{g} / \mathrm{kg}$ & $<1,8$ & $<0,44$ & $<1,0$ & - & $<2,0$ & $<1,8$ & $<0,56$ & $<1$ & - & $<3$ & $<1,0$ & $<0$ & $<1$ & - & $<1$ \\
\hline Ciprofloxacine & $\mu \mathrm{g} / \mathrm{kg}$ & 0,77 & 1,2 & 0 & - & 3 & 0,33 & 0,72 & 0 & - & 2 & $<1,1$ & $<0,35$ & $<1$ & - & $<2$ \\
\hline Enrofloxacine & $\mu \mathrm{g} / \mathrm{kg}$ & $<5,6$ & $<2,7$ & $<2,0$ & - & $<10$ & $<5,2$ & $<3,5$ & $<2$ & - & $<10$ & 0,13 & 0,52 & 0 & - & 2 \\
\hline Flumequine & $\mu \mathrm{g} / \mathrm{kg}$ & 412 & 317 & 147 & - & 1200 & 284 & 115 & 148 & - & 590 & 195 & 155 & 65 & - & 650 \\
\hline Lincomycine & $\mu \mathrm{g} / \mathrm{kg}$ & $<2,2$ & $<1,2$ & $<1,0$ & - & $<5,0$ & $<2,2$ & $<1,4$ & $<1$ & - & $<5$ & $<1,2$ & $<0,41$ & $<1$ & - & $<2$ \\
\hline Tilmicosine & $\mu \mathrm{g} / \mathrm{kg}$ & 135 & 104 & 47 & - & 440 & 102 & 46 & 2 & - & 174 & 15 & 15 & 0 & - & 55 \\
\hline Florfenicol & $\mu \mathrm{g} / \mathrm{kg}$ & $<1,2$ & $<0,55$ & $<1,0$ & - & $<3,0$ & $<1,1$ & $<0,52$ & $<1$ & - & $<3$ & $<1,1$ & $<0,26$ & $<1$ & - & $<2$ \\
\hline Chloortetracycline & $\mu \mathrm{g} / \mathrm{kg}$ & 24 & 47 & 0 & - & 146 & 3,4 & 7,3 & 0 & - & 20 & 1,4 & 4,4 & 0 & - & 14 \\
\hline Tetracycline & $\mu \mathrm{g} / \mathrm{kg}$ & 16 & 11 & 0 & - & 39 & 12 & 5,2 & 0 & - & 19 & 4,7 & 11 & 0 & - & 31 \\
\hline Minocycline & $\mu \mathrm{g} / \mathrm{kg}$ & $<23$ & $<6,2$ & $<10$ & - & $<30$ & $<20$ & $<8,3$ & $<5$ & - & $<30$ & $<11$ & $<8,6$ & $<1$ & - & $<30$ \\
\hline Methacycline & $\mu \mathrm{g} / \mathrm{kg}$ & $<10$ & $<2,5$ & $<5,0$ & - & $<15$ & $<9,7$ & $<3,9$ & $<2$ & - & $<15$ & $<4,2$ & $<2,4$ & $<2$ & - & $<10$ \\
\hline Sulfathiazol & $\mu \mathrm{g} / \mathrm{kg}$ & $<3,2$ & $<1,9$ & $<1,0$ & - & $<5,0$ & $<2,8$ & $<1,8$ & $<1$ & - & $<5$ & $<1,8$ & $<1,2$ & $<1$ & - & $<5$ \\
\hline Sulfapyridine & $\mu \mathrm{g} / \mathrm{kg}$ & $<2,3$ & $<1,4$ & $<1,0$ & - & $<5,0$ & $<1,9$ & $<1,3$ & $<1$ & - & $<5$ & $<1,1$ & $<0,32$ & $<1$ & - & $<2$ \\
\hline Sulfamerazine & $\mu \mathrm{g} / \mathrm{kg}$ & $<1,0$ & $<0$ & $<1,0$ & - & $<1,0$ & $<1,0$ & $<0$ & $<1$ & - & $<1$ & $<1,0$ & $<0$ & $<1$ & - & $<1$ \\
\hline Sulfamoxol & $\mu \mathrm{g} / \mathrm{kg}$ & $<1,1$ & $<0,33$ & $<1,0$ & - & $<2,0$ & $<1,1$ & $<0,32$ & $<1$ & - & $<2$ & $<1,0$ & $<0$ & $<1$ & - & $<1$ \\
\hline Sulfamethizol & $\mu \mathrm{g} / \mathrm{kg}$ & $<1,2$ & $<0,44$ & $<1,0$ & - & $<2,0$ & $<1,1$ & $<0,32$ & $<1$ & - & $<2$ & $<1,1$ & $<0,32$ & $<1$ & - & $<2$ \\
\hline Sulfamethoxypyridazine & $\mu \mathrm{g} / \mathrm{kg}$ & $<1,0$ & $<0$ & $<1,0$ & - & $<1,0$ & $<1,0$ & $<0$ & $<1$ & - & $<1$ & $<1,0$ & $<0$ & $<1$ & - & $<1$ \\
\hline Sulfamonomethoxine & $\mu \mathrm{g} / \mathrm{kg}$ & $<1,2$ & $<0,44$ & $<1,0$ & - & $<2,0$ & $<1,2$ & $<0,42$ & $<1$ & - & $<2$ & $<1,1$ & $<0,32$ & $<1$ & - & $<2$ \\
\hline
\end{tabular}




\begin{tabular}{|c|c|c|c|c|c|c|c|c|c|c|c|c|c|c|c|c|}
\hline Sulfachloorpyridazine & $\mu \mathrm{g} / \mathrm{kg}$ & $<2,3$ & $<0,71$ & $<1,0$ & - & $<3,0$ & $<1,7$ & $<0,48$ & $<1$ & - & $<2$ & $<1,3$ & $<0,67$ & $<1$ & - & $<3$ \\
\hline Sulfadoxine & $\mu \mathrm{g} / \mathrm{kg}$ & $<1,0$ & $<0$ & $<1,0$ & - & $<1,0$ & $<1,0$ & $<0$ & $<1$ & - & $<1$ & $<1,0$ & $<0$ & $<1$ & - & $<1$ \\
\hline Sulfamethoxazol & $\mu \mathrm{g} / \mathrm{kg}$ & $<1,3$ & $<0,50$ & $<1,0$ & - & $<2,0$ & 0,2 & 0,63 & 0 & - & 2 & $<1,1$ & $<0,32$ & $<1$ & - & $<2$ \\
\hline Sulfisoxazol & $\mu \mathrm{g} / \mathrm{kg}$ & $<1,7$ & $<0,50$ & $<1,0$ & - & $<2,0$ & $<1,6$ & $<0,52$ & $<1$ & - & $<2$ & $<1,1$ & $<0,32$ & $<1$ & - & $<2$ \\
\hline Sulfadimethoxine & $\mu \mathrm{g} / \mathrm{kg}$ & $<1,2$ & $<0,44$ & $<1,0$ & - & $<2,0$ & $<1,0$ & $<0$ & $<1$ & - & $<1$ & $<1,0$ & $<0$ & $<1$ & - & $<1$ \\
\hline Sulfaquinoxaline & $\mu \mathrm{g} / \mathrm{kg}$ & $<1,4$ & $<0,53$ & $<1,0$ & - & $<2,0$ & $<1,4$ & $<0,52$ & $<1$ & - & $<2$ & $<1,1$ & $<0,32$ & $<1$ & - & $<2$ \\
\hline Sulfacetamide & $\mu \mathrm{g} / \mathrm{kg}$ & $<1,0$ & $<0$ & $<1,0$ & - & $<1,0$ & $<1,4$ & $<1,3$ & $<1$ & - & $<5$ & $<1,0$ & $<0$ & $<1$ & - & $<1$ \\
\hline Sulfaphenazol & $\mu \mathrm{g} / \mathrm{kg}$ & $<10$ & $<0$ & $<10$ & - & $<10$ & $<8,5$ & $<3,2$ & $<2$ & - & $<10$ & $<3,9$ & $<3,4$ & $<1$ & - & $<10$ \\
\hline Dapson & $\mu \mathrm{g} / \mathrm{kg}$ & $<1,0$ & $<0$ & $<1,0$ & - & $<1,0$ & $<1,1$ & $<0,32$ & $<1$ & - & $<2$ & $<1,0$ & $<0$ & $<1$ & - & $<1$ \\
\hline Marbofloxacine & $\mu \mathrm{g} / \mathrm{kg}$ & 1 & 2,3 & 0 & - & 7 & $<3,6$ & $<2,6$ & $<1$ & - & $<10$ & 0,4 & 0,97 & 0 & - & 3 \\
\hline Norfloxacine & $\mu \mathrm{g} / \mathrm{kg}$ & $<12$ & $<5,1$ & $<5,0$ & - & $<20$ & $<8,6$ & $<4,5$ & $<3$ & - & $<15$ & $<3,8$ & $<4,2$ & $<1$ & - & $<15$ \\
\hline Danofloxacine & $\mu \mathrm{g} / \mathrm{kg}$ & $<8,8$ & $<6,0$ & $<2,0$ & - & $<20$ & $<8,0$ & $<4,7$ & $<1$ & - & $<15$ & $<2,0$ & $<1,2$ & $<1$ & - & $<5$ \\
\hline Sarafloxacine & $\mu \mathrm{g} / \mathrm{kg}$ & $<12$ & $<4,8$ & $<3,0$ & - & $<20$ & $<12$ & $<4,6$ & $<3$ & - & $<20$ & $<6,3$ & $<3,3$ & $<2$ & - & $<10$ \\
\hline Difloxacine & $\mu \mathrm{g} / \mathrm{kg}$ & $<5,3$ & $<2,9$ & $<2,0$ & - & $<10$ & $<4,0$ & $<1,3$ & $<2$ & - & $<5$ & $<1,9$ & $<1,3$ & $<1$ & - & $<5$ \\
\hline Oxolinezuur & $\mu \mathrm{g} / \mathrm{kg}$ & $<3,9$ & $<1,1$ & $<3,0$ & - & $<5,0$ & $<3,6$ & $<1,3$ & $<1$ & - & $<5$ & $<1,5$ & $<0,85$ & $<1$ & - & $<3$ \\
\hline Nalidixinezuur & $\mu \mathrm{g} / \mathrm{kg}$ & $<3,8$ & $<4,2$ & $<2,0$ & - & $<15$ & $<3,0$ & $<2,5$ & $<1$ & - & $<10$ & $<1,2$ & $<0,42$ & $<1$ & - & $<2$ \\
\hline Levofloxacin/ofloxacin & $\mu \mathrm{g} / \mathrm{kg}$ & $<4,3$ & $<1,0$ & $<3,0$ & - & $<5,0$ & $<3,9$ & $<1,5$ & $<1$ & - & $<5$ & $<3,7$ & $<1,8$ & $<1$ & - & $<5$ \\
\hline Trovafloxacin & $\mu \mathrm{g} / \mathrm{kg}$ & $<1,8$ & $<1,3$ & $<1,0$ & - & $<5,0$ & $<1,6$ & $<0,70$ & $<1$ & - & $<3$ & $<1,1$ & $<0,32$ & $<1$ & - & $<2$ \\
\hline Erythromycine & $\mu \mathrm{g} / \mathrm{kg}$ & $<17$ & $<13$ & $<5,0$ & - & $<40$ & $<14$ & $<11$ & $<1$ & - & $<40$ & $<1,6$ & $<1,3$ & $<1$ & - & $<5$ \\
\hline Tylosine & $\mu \mathrm{g} / \mathrm{kg}$ & $<23$ & $<34$ & $<3,0$ & - & $<100$ & $<14$ & $<17$ & $<3$ & - & $<50$ & $<11$ & $<21$ & $<2$ & - & $<70$ \\
\hline Josamycine & $\mu \mathrm{g} / \mathrm{kg}$ & $<12$ & $<19$ & $<1,0$ & - & $<50$ & $<5,7$ & $<12$ & $<1$ & - & $<40$ & $<4,1$ & $<9,1$ & $<1$ & - & $<30$ \\
\hline Spiramycine & $\mu \mathrm{g} / \mathrm{kg}$ & $<9,4$ & $<3,0$ & $<5,0$ & - & $<15$ & $<6,7$ & $<3,8$ & $<2$ & - & $<15$ & $<2,8$ & $<2,6$ & $<1$ & - & $<10$ \\
\hline Neospiramycine 1 & $\mu \mathrm{g} / \mathrm{kg}$ & $<6,4$ & $<5,5$ & $<3,0$ & - & $<20$ & $<6,7$ & $<4,8$ & $<3$ & - & $<15$ & $<6,2$ & $<4,1$ & $<3$ & - & $<15$ \\
\hline Tiamulin & $\mu \mathrm{g} / \mathrm{kg}$ & $<3,6$ & $<3,0$ & $<1,0$ & - & $<10$ & $<3,2$ & $<2,0$ & $<1$ & - & $<5$ & $<1,1$ & $<0,32$ & $<1$ & - & $<2$ \\
\hline Tulathromycine & $\mu \mathrm{g} / \mathrm{kg}$ & 1,1 & 0,93 & 0 & - & 2 & 1,1 & 1,2 & 0 & - & 3 & 1,7 & 4,4 & 0 & - & 14 \\
\hline Pirlimycine & $\mu \mathrm{g} / \mathrm{kg}$ & $<2,7$ & $<1,4$ & $<1,0$ & - & $<5,0$ & $<2,2$ & $<1,1$ & $<1$ & - & $<5$ & $<1,2$ & $<0,63$ & $<1$ & - & $<3$ \\
\hline Valnemulin & $\mu \mathrm{g} / \mathrm{kg}$ & $<1,4$ & $<1,3$ & $<1,0$ & - & $<5,0$ & $<1,4$ & $<1,3$ & $<1$ & - & $<5$ & 0,2 & 0,63 & 0 & - & 2 \\
\hline Tylvalosine & $\mu \mathrm{g} / \mathrm{kg}$ & $<2,8$ & $<2,8$ & $<1,0$ & - & $<10$ & $<2,6$ & $<2,7$ & $<1$ & - & $<10$ & $<2,1$ & $<1,1$ & $<1$ & - & $<5$ \\
\hline Natamycin & $\mu \mathrm{g} / \mathrm{kg}$ & $<12$ & $<11$ & $<2,0$ & - & $<30$ & $<7,3$ & $<8,5$ & $<2$ & - & $<25$ & $<3,4$ & $<4,9$ & $<1$ & - & $<15$ \\
\hline
\end{tabular}




\begin{tabular}{|c|c|c|c|c|c|c|c|c|c|c|c|c|c|c|c|c|}
\hline Gamithromycine & $\mu \mathrm{g} / \mathrm{kg}$ & $<2,4$ & $<1,1$ & $<1,0$ & - & $<5,0$ & $<2,1$ & $<1,2$ & $<1$ & - & $<5$ & $<2,2$ & $<1,5$ & $<1$ & - & $<5$ \\
\hline Tildipirosine & $\mu \mathrm{g} / \mathrm{kg}$ & $<1,0$ & $<0$ & $<1,0$ & - & $<1,0$ & $<1,2$ & $<0,67$ & $<1$ & - & $<3$ & $<4,2$ & $<4,0$ & $<1$ & - & $<10$ \\
\hline Vancomycine & $\mu \mathrm{g} / \mathrm{kg}$ & $<18$ & $<17$ & $<5,0$ & - & $<40$ & $<11$ & $<8,8$ & $<3$ & - & $<30$ & $<4,5$ & $<9,1$ & $<1$ & - & $<30$ \\
\hline Azithromycine & $\mu \mathrm{g} / \mathrm{kg}$ & $<1,3$ & $<0,71$ & $<1,0$ & - & $<3,0$ & $<1,4$ & $<0,70$ & $<1$ & - & $<3$ & $<1,0$ & $<0$ & $<1$ & - & $<1$ \\
\hline Clarithromycine & $\mu \mathrm{g} / \mathrm{kg}$ & $<4,1$ & $<4,4$ & $<1,0$ & - & $<10$ & $<2,5$ & $<2,9$ & $<1$ & - & $<10$ & $<1,9$ & $<2,8$ & $<1$ & - & $<10$ \\
\hline
\end{tabular}




\section{Analyseresultaten Indampen}

\begin{tabular}{|c|c|c|c|c|c|c|c|c|c|c|c|c|c|c|c|c|}
\hline \multirow[b]{2}{*}{ Parameter } & \multirow[b]{2}{*}{ Eenheid } & \multirow[b]{2}{*}{ Gem. } & \multicolumn{4}{|c|}{ Ruwe mest } & \multicolumn{5}{|c|}{ Invoer droger } & \multicolumn{5}{|c|}{ Effluent } \\
\hline & & & SD & Min & - & $\operatorname{Max}$ & Gem. & SD & Min & - & $\operatorname{Max}$ & Gem. & SD & Min & - & Max \\
\hline \multicolumn{17}{|c|}{ Algemene chemische parameters } \\
\hline BZV & $\mathrm{mg} / \mathrm{l}$ & 10200 & NA & 10200 & - & 10200 & 8034 & 849 & 7180 & - & 9420 & 29 & 36 & 3 & - & 92 \\
\hline CZV & $\mathrm{mg} / \mathrm{l}$ & 73000 & NA & 73000 & - & 73000 & 32100 & 2798 & 29700 & - & 36600 & 70 & 102 & 12 & - & 250 \\
\hline Onopgeloste stoffen & $\mathrm{mg} / \mathrm{l}$ & NA & NA & 0 & - & 0 & NA & NA & 0 & - & 0 & $<5,8$ & $<1,8$ & $<5$ & - & $<9$ \\
\hline P-totaal & $\mathrm{mg} / \mathrm{kg}$ & NA & NA & 0 & - & 0 & 464 & 259 & 212 & - & 718 & 3,7 & 3,8 & 0 & - & 9 \\
\hline P-PO4 & $\mathrm{mg} / \mathrm{kg}$ & NA & NA & 0 & - & 0 & 350 & 228 & 130 & - & 569 & 1,1 & 1,4 & 0 & - & 3,1 \\
\hline $\mathrm{N}$-totaal & $\mathrm{mg} / \mathrm{kg}$ & NA & NA & 0 & - & 0 & 6112 & 399 & 5526 & - & 6368 & 28 & 52 & 0 & - & 106 \\
\hline $\mathrm{N}-\mathrm{NH}_{4}$ & $\mathrm{mg} / \mathrm{kg}$ & NA & NA & 0 & - & 0 & 4568 & 440 & 3968 & - & 5026 & 25 & 34 & 2,1 & - & 75 \\
\hline $\mathrm{NO}_{2}-\mathrm{N}+\mathrm{NO}_{3}-\mathrm{N}$ & $\mathrm{mg} / \mathrm{kg}$ & NA & NA & 0 & - & 0 & 5,1 & 4,2 & 1,1 & - & 9,2 & 4,6 & 4,7 & 0 & - & 8,6 \\
\hline $\mathrm{pH}$ & $(-)$ & NA & NA & 0 & - & 0 & 8,6 & 0,27 & 8,4 & - & 8,9 & 7,1 & 1,9 & 5,8 & - & 10 \\
\hline EC & $\mathrm{mS}$ & NA & NA & 0 & - & 0 & 38 & 2,4 & 36 & - & 41 & 0,08 & 0,07 & 0,02 & - & 0,16 \\
\hline $\mathrm{Cl}-$ & $\mathrm{mg} / \mathrm{kg}$ & 1700 & NA & 1700 & - & 1700 & 2333 & 173 & 2100 & - & 2546 & 0 & 0 & 0 & - & 0 \\
\hline $\mathrm{S}$ & $\mathrm{mg} / \mathrm{kg}$ & NA & NA & 0 & - & 0 & 840 & 615 & 290 & - & 1490 & 2,5 & 5 & 0 & - & 10 \\
\hline K & $\mathrm{mg} / \mathrm{kg}$ & NA & NA & 0 & - & 0 & 4325 & 250 & 4000 & - & 4600 & 0 & 0 & 0 & - & 0 \\
\hline \multicolumn{17}{|l|}{ Zware metalen } \\
\hline $\mathrm{Cd}$ & $\mathrm{mg} / \mathrm{kg}$ & NA & NA & 0 & - & 0 & $<0,027$ & $<0$ & $<0,027$ & - & $<0,027$ & $<0,03$ & $<0$ & $<0,027$ & - & $<0,027$ \\
\hline $\mathrm{Hg}$ & $\mathrm{mg} / \mathrm{kg}$ & NA & NA & 0 & - & 0 & $<0,012$ & $<0,00$ & $<0,012$ & - & $<0,012$ & 0,02 & 0,03 & 0 & - & 0,06 \\
\hline $\mathrm{Pb}$ & $\mathrm{mg} / \mathrm{kg}$ & NA & NA & 0 & - & 0 & $<0,013$ & $<0$ & $<0,013$ & - & $<0,013$ & 0,01 & 0,02 & 0 & - & 0,04 \\
\hline As & $\mathrm{mg} / \mathrm{kg}$ & NA & NA & 0 & - & 0 & $<0,11$ & $<0$ & $<0,11$ & - & $<0,11$ & $<0,11$ & $<0$ & $<0,11$ & - & $<0,11$ \\
\hline $\mathrm{Cr}$ & $\mathrm{mg} / \mathrm{kg}$ & NA & NA & 0 & - & 0 & 0,12 & 0,11 & 0 & - & 0,21 & 1,4 & 2,8 & 0 & - & 5,6 \\
\hline $\mathrm{Ni}$ & $\mathrm{mg} / \mathrm{kg}$ & NA & NA & 0 & - & 0 & 0,53 & 0,02 & 0,5 & - & 0,54 & 1,2 & 2,4 & 0 & - & 4,7 \\
\hline $\mathrm{Cu}$ & $\mathrm{mg} / \mathrm{kg}$ & NA & NA & 0 & - & 0 & $<0,57$ & $<0$ & $<0,57$ & - & $<0,57$ & $<0,57$ & $<0$ & $<0,57$ & - & $<0,57$ \\
\hline$Z n$ & $\mathrm{mg} / \mathrm{kg}$ & NA & NA & 0 & - & 0 & 0,43 & 0,75 & 0 & - & 1,3 & 0,48 & 0,95 & 0 & - & 1,9 \\
\hline $\mathrm{Ba}$ & $\mathrm{mg} / \mathrm{kg}$ & NA & NA & 0 & - & 0 & $<0,16$ & $<0$ & $<0,16$ & - & $<0,16$ & $<0,16$ & $<0$ & $<0,16$ & - & $<0,16$ \\
\hline
\end{tabular}




\begin{tabular}{|c|c|c|c|c|c|c|c|c|c|c|c|c|c|c|c|c|}
\hline v & $\mathrm{mg} / \mathrm{kg}$ & NA & NA & 0 & - & 0 & $<0,28$ & $<0$ & $<0,28$ & - & $<0,28$ & $<0,28$ & $<0$ & $<0,28$ & - & $<0,28$ \\
\hline U & $\mathrm{mg} / \mathrm{kg}$ & NA & NA & 0 & - & 0 & $<0,062$ & $<0$ & $<0,062$ & - & $<0,062$ & $<0,06$ & $<0$ & $<0,062$ & - & $<0,062$ \\
\hline Co & $\mathrm{mg} / \mathrm{kg}$ & NA & NA & 0 & - & 0 & NA & NA & 0 & - & 0 & NA & NA & 0 & - & 0 \\
\hline Se & $\mathrm{mg} / \mathrm{kg}$ & NA & NA & 0 & - & 0 & NA & NA & 0 & - & 0 & NA & NA & 0 & - & 0 \\
\hline \multicolumn{17}{|l|}{ Hormoonstoffen } \\
\hline ER-CALUX & n EEQ/g & NA & NA & 0 & - & 0 & 0,36 & 0,24 & 0,19 & - & 0,53 & 0,02 & 0,03 & 0 & - & 0,05 \\
\hline Antibiotica & & & & & & & & & & & & & & & - & \\
\hline Oxytetracycline & $\mu \mathrm{g} / \mathrm{kg}$ & $<5$ & NA & $<5$ & - & $<5$ & $<9,6$ & $<6,6$ & $<3$ & - & $<20$ & 0,67 & 1,6 & 0 & - & 4 \\
\hline Doxycycline & $\mu \mathrm{g} / \mathrm{kg}$ & 60 & NA & 60 & - & 60 & 18 & 11 & 6 & - & 30 & 0,5 & 1,2 & 0 & - & 3 \\
\hline Sulfadiazine & $\mu \mathrm{g} / \mathrm{kg}$ & 580 & NA & 580 & - & 580 & 7 & 8,7 & 0 & - & 21 & $<1,0$ & $<0$ & $<1$ & - & $<1$ \\
\hline Sulfadimidine & $\mu \mathrm{g} / \mathrm{kg}$ & $<1$ & NA & $<1$ & - & $<1$ & $<1$ & $<0$ & $<1$ & - & $<1$ & $<1,0$ & $<0$ & $<1$ & - & $<1$ \\
\hline Trimethoprim & $\mu \mathrm{g} / \mathrm{kg}$ & 13 & NA & 13 & - & 13 & $<1$ & $<0$ & $<1$ & - & $<1$ & $<1,0$ & $<0$ & $<1$ & - & $<1$ \\
\hline Ciprofloxacine & $\mu \mathrm{g} / \mathrm{kg}$ & $<2$ & NA & $<2$ & - & $<2$ & $<3,4$ & $<0,89$ & $<3$ & - & $<5$ & 0,33 & 0,82 & 0 & - & 2 \\
\hline Enrofloxacine & $\mu \mathrm{g} / \mathrm{kg}$ & $<5$ & NA & $<5$ & - & $<5$ & $<9$ & $<2,2$ & $<5$ & - & $<10$ & 0,33 & 0,82 & 0 & - & 2 \\
\hline Flumequine & $\mu \mathrm{g} / \mathrm{kg}$ & $<3$ & NA & $<3$ & - & $<3$ & 1 & 1,2 & 0 & - & 3 & 0,17 & 0,41 & 0 & - & 1 \\
\hline Lincomycine & $\mu \mathrm{g} / \mathrm{kg}$ & $<1$ & NA & $<1$ & - & $<1$ & $<2,6$ & $<1,5$ & $<1$ & - & $<5$ & $<1,2$ & $<0,41$ & $<1$ & - & $<2$ \\
\hline Tilmicosine & $\mu \mathrm{g} / \mathrm{kg}$ & $<1$ & NA & $<1$ & - & $<1$ & $<2,2$ & $<1,6$ & $<1$ & - & $<5$ & 1,4 & 2,2 & 0 & - & 5 \\
\hline Florfenicol & $\mu \mathrm{g} / \mathrm{kg}$ & $<1$ & NA & $<1$ & - & $<1$ & $<1$ & $<0$ & $<1$ & - & $<1$ & $<1,0$ & $<0$ & $<1$ & - & $<1$ \\
\hline Chloortetracycline & $\mu \mathrm{g} / \mathrm{kg}$ & $<10$ & NA & $<10$ & - & $<10$ & $<13$ & $<5,7$ & $<5$ & - & $<20$ & $<6,0$ & $<5,3$ & $<2$ & - & $<15$ \\
\hline Tetracycline & $\mu \mathrm{g} / \mathrm{kg}$ & $<10$ & NA & $<10$ & - & $<10$ & $<9$ & $<2,2$ & $<5$ & - & $<10$ & $<2,7$ & $<1,2$ & $<2$ & - & $<5$ \\
\hline Minocycline & $\mu \mathrm{g} / \mathrm{kg}$ & $<10$ & NA & $<10$ & - & $<10$ & $<30$ & $<21$ & $<5$ & - & $<60$ & $<8,2$ & $<5,2$ & $<1$ & - & $<15$ \\
\hline Methacycline & $\mu \mathrm{g} / \mathrm{kg}$ & $<15$ & NA & $<15$ & - & $<15$ & $<16$ & $<6,5$ & $<10$ & - & $<25$ & $<6,5$ & $<9,1$ & $<2$ & - & $<25$ \\
\hline Sulfathiazol & $\mu \mathrm{g} / \mathrm{kg}$ & $<1$ & NA & $<1$ & - & $<1$ & $<2,2$ & $<1,8$ & $<1$ & - & $<5$ & $<1,2$ & $<0,41$ & $<1$ & - & $<2$ \\
\hline Sulfapyridine & $\mu \mathrm{g} / \mathrm{kg}$ & $<1$ & NA & $<1$ & - & $<1$ & $<1,8$ & $<0,84$ & $<1$ & - & $<3$ & $<1,0$ & $<0$ & $<1$ & - & $<1$ \\
\hline Sulfamerazine & $\mu \mathrm{g} / \mathrm{kg}$ & $<1$ & NA & $<1$ & - & $<1$ & $<1$ & $<0$ & $<1$ & - & $<1$ & $<1,0$ & $<0$ & $<1$ & - & $<1$ \\
\hline Sulfamoxol & $\mu \mathrm{g} / \mathrm{kg}$ & $<2$ & NA & $<2$ & - & $<2$ & $<1,4$ & $<0,89$ & $<1$ & - & $<3$ & $<1,2$ & $<0,41$ & $<1$ & - & $<2$ \\
\hline Sulfamethizol & $\mu \mathrm{g} / \mathrm{kg}$ & $<2$ & NA & $<2$ & - & $<2$ & $<1,4$ & $<0,55$ & $<1$ & - & $<2$ & $<1,0$ & $<0$ & $<1$ & - & $<1$ \\
\hline Sulfamethoxypyridazine & $\mu \mathrm{g} / \mathrm{kg}$ & $<1$ & NA & $<1$ & - & $<1$ & $<1$ & $<0$ & $<1$ & - & $<1$ & $<1,0$ & $<0$ & $<1$ & - & $<1$ \\
\hline Sulfamonomethoxine & $\mu \mathrm{g} / \mathrm{kg}$ & $<2$ & NA & $<2$ & - & $<2$ & $<1,4$ & $<0,55$ & $<1$ & - & $<2$ & $<1,2$ & $<0,41$ & $<1$ & - & $<2$ \\
\hline
\end{tabular}




\begin{tabular}{|c|c|c|c|c|c|c|c|c|c|c|c|c|c|c|c|c|}
\hline Sulfachloorpyridazine & $\mu \mathrm{g} / \mathrm{kg}$ & $<1$ & NA & $<1$ & - & $<1$ & $<2,2$ & $<1,6$ & $<1$ & - & $<5$ & $<1,0$ & $<0$ & $<1$ & - & $<1$ \\
\hline Sulfadoxine & $\mu \mathrm{g} / \mathrm{kg}$ & $<1$ & NA & $<1$ & - & $<1$ & $<1$ & $<0$ & $<1$ & - & $<1$ & $<1,0$ & $<0$ & $<1$ & - & $<1$ \\
\hline Sulfamethoxazol & $\mu \mathrm{g} / \mathrm{kg}$ & $<1$ & NA & $<1$ & - & $<1$ & $<1,6$ & $<0,89$ & $<1$ & - & $<3$ & $<1,0$ & $<0$ & $<1$ & - & $<1$ \\
\hline Sulfisoxazol & $\mu \mathrm{g} / \mathrm{kg}$ & $<2$ & NA & $<2$ & - & $<2$ & $<1,8$ & $<0,45$ & $<1$ & - & $<2$ & $<1,2$ & $<0,41$ & $<1$ & - & $<2$ \\
\hline Sulfadimethoxine & $\mu \mathrm{g} / \mathrm{kg}$ & $<1$ & NA & $<1$ & - & $<1$ & $<1,2$ & $<0,45$ & $<1$ & - & $<2$ & $<1,0$ & $<0$ & $<1$ & - & $<1$ \\
\hline Sulfaquinoxaline & $\mu \mathrm{g} / \mathrm{kg}$ & $<2$ & NA & $<2$ & - & $<2$ & $<2$ & $<0,71$ & $<1$ & - & $<3$ & $<1,2$ & $<0,41$ & $<1$ & - & $<2$ \\
\hline Sulfacetamide & $\mu \mathrm{g} / \mathrm{kg}$ & $<1$ & NA & $<1$ & - & $<1$ & $<1,8$ & $<1,8$ & $<1$ & - & $<5$ & $<1,0$ & $<0$ & $<1$ & - & $<1$ \\
\hline Sulfaphenazol & $\mu \mathrm{g} / \mathrm{kg}$ & $<10$ & NA & $<10$ & - & $<10$ & $<10$ & $<3,5$ & $<5$ & - & $<15$ & $<4,0$ & $<4,6$ & $<1$ & - & $<10$ \\
\hline Dapson & $\mu g / k g$ & $<1$ & NA & $<1$ & - & $<1$ & $<1$ & $<0$ & $<1$ & - & $<1$ & $<1,0$ & $<0$ & $<1$ & - & $<1$ \\
\hline Marbofloxacine & $\mu \mathrm{g} / \mathrm{kg}$ & $<2$ & NA & $<2$ & - & $<2$ & $<3$ & $<1,2$ & $<2$ & - & $<5$ & $<1,0$ & $<0$ & $<1$ & - & $<1$ \\
\hline Norfloxacine & $\mu \mathrm{g} / \mathrm{kg}$ & $<10$ & NA & $<10$ & - & $<10$ & $<12,6$ & $<11$ & $<3$ & - & $<30$ & $<2,8$ & $<3,5$ & $<1$ & - & $<10$ \\
\hline Danofloxacine & $\mu g / k g$ & $<3$ & NA & $<3$ & - & $<3$ & $<7,6$ & $<3,4$ & $<3$ & - & $<10$ & $<1,0$ & $<0$ & $<1$ & - & $<1$ \\
\hline Sarafloxacine & $\mu \mathrm{g} / \mathrm{kg}$ & $<3$ & NA & $<3$ & - & $<3$ & $<12$ & $<5,7$ & $<5$ & - & $<20$ & $<5,0$ & $<5,2$ & $<1$ & - & $<15$ \\
\hline Difloxacine & $\mu \mathrm{g} / \mathrm{kg}$ & $<2$ & NA & $<2$ & - & $<2$ & $<6,6$ & $<3,2$ & $<3$ & - & $<10$ & $<1,0$ & $<0$ & $<1$ & - & $<1$ \\
\hline Oxolinezuur & $\mu g / k g$ & $<3$ & NA & $<3$ & - & $<3$ & $<5,2$ & $<2,9$ & $<3$ & - & $<10$ & $<1,2$ & $<0,41$ & $<1$ & - & $<2$ \\
\hline Nalidixinezuur & $\mu \mathrm{g} / \mathrm{kg}$ & $<2$ & NA & $<2$ & - & $<2$ & $<2,4$ & $<0,55$ & $<2$ & - & $<3$ & $<1,0$ & $<0$ & $<1$ & - & $<1$ \\
\hline Levofloxacin/ofloxacin & $\mu \mathrm{g} / \mathrm{kg}$ & $<3$ & NA & $<3$ & - & $<3$ & $<3,8$ & $<1,1$ & $<3$ & - & $<5$ & $<3,2$ & $<2,0$ & $<1$ & - & $<5$ \\
\hline Trovafloxacin & $\mu \mathrm{g} / \mathrm{kg}$ & $<1$ & NA & $<1$ & - & $<1$ & $<2$ & $<0,71$ & $<1$ & - & $<3$ & $<1,3$ & $<0,82$ & $<1$ & - & $<3$ \\
\hline Erythromycine & $\mu \mathrm{g} / \mathrm{kg}$ & $<30$ & NA & $<30$ & - & $<30$ & $<14$ & $<15$ & $<5$ & - & $<40$ & $<1,3$ & $<0,82$ & $<1$ & - & $<3$ \\
\hline Tylosine & $\mu \mathrm{g} / \mathrm{kg}$ & $<15$ & NA & $<15$ & - & $<15$ & $<8,4$ & $<8,5$ & $<2$ & - & $<20$ & $<7,2$ & $<5,4$ & $<1$ & - & $<15$ \\
\hline Josamycine & $\mu \mathrm{g} / \mathrm{kg}$ & $<5$ & NA & $<5$ & - & $<5$ & $<15$ & $<25$ & $<1$ & - & $<60$ & $<1,3$ & $<0,82$ & $<1$ & - & $<3$ \\
\hline Spiramycine & $\mu \mathrm{g} / \mathrm{kg}$ & $<15$ & NA & $<15$ & - & $<15$ & $<11$ & $<5,5$ & $<5$ & - & $<20$ & $<31$ & $<46$ & $<1$ & - & $<100$ \\
\hline Neospiramycine 1 & $\mu \mathrm{g} / \mathrm{kg}$ & $<15$ & NA & $<15$ & - & $<15$ & $<8,2$ & $<6,3$ & $<3$ & - & $<15$ & $<11$ & $<13$ & $<4$ & - & $<30$ \\
\hline Tiamulin & $\mu \mathrm{g} / \mathrm{kg}$ & $<1$ & NA & $<1$ & - & $<1$ & $<1,4$ & $<0,55$ & $<1$ & - & $<2$ & $<1,0$ & $<0$ & $<1$ & - & $<1$ \\
\hline Tulathromycine & $\mu \mathrm{g} / \mathrm{kg}$ & $<10$ & NA & $<10$ & - & $<10$ & $<6,4$ & $<4,9$ & $<1$ & - & $<10$ & $<1,0$ & $<0$ & $<1$ & - & $<1$ \\
\hline Pirlimycine & $\mu \mathrm{g} / \mathrm{kg}$ & $<2$ & NA & $<2$ & - & $<2$ & $<3,4$ & $<3,8$ & $<1$ & - & $<10$ & $<1,2$ & $<0,41$ & $<1$ & - & $<2$ \\
\hline Valnemulin & $\mu \mathrm{g} / \mathrm{kg}$ & $<1$ & NA & $<1$ & - & $<1$ & $<1,2$ & $<0,45$ & $<1$ & - & $<2$ & $<1,7$ & $<1,6$ & $<1$ & - & $<5$ \\
\hline Tylvalosine & $\mu \mathrm{g} / \mathrm{kg}$ & $<1$ & NA & $<1$ & - & $<1$ & $<1,6$ & $<0,89$ & $<1$ & - & $<3$ & $<2,5$ & $<1,4$ & $<1$ & - & $<5$ \\
\hline Natamycin & $\mu \mathrm{g} / \mathrm{kg}$ & $<25$ & NA & $<25$ & - & $<25$ & $<13,8$ & $<15$ & $<2$ & - & $<30$ & $<2,7$ & $<3,6$ & $<1$ & - & $<10$ \\
\hline
\end{tabular}




\begin{tabular}{|c|c|c|c|c|c|c|c|c|c|c|c|c|c|c|c|c|}
\hline Gamithromycine & $\mu \mathrm{g} / \mathrm{kg}$ & $<5$ & NA & $<5$ & - & $<5$ & $<2$ & $<1,7$ & $<1$ & - & $<5$ & $<2,0$ & $<0,82$ & $<1$ & - & $<3$ \\
\hline Tildipirosine & $\mu \mathrm{g} / \mathrm{kg}$ & $<2$ & NA & $<2$ & - & $<2$ & $<2,8$ & $<4,0$ & $<1$ & - & $<10$ & $<11$ & $<19$ & $<1$ & - & $<40$ \\
\hline Vancomycine & $\mu \mathrm{g} / \mathrm{kg}$ & $<3$ & NA & $<3$ & - & $<3$ & $<17$ & $<24$ & $<5$ & - & $<60$ & $<2,7$ & $<3,6$ & $<1$ & - & $<10$ \\
\hline Azithromycine & $\mu \mathrm{g} / \mathrm{kg}$ & $<2$ & NA & $<2$ & - & $<2$ & $<2$ & $<1,7$ & $<1$ & - & $<5$ & $<1,7$ & $<1,6$ & $<1$ & - & $<5$ \\
\hline Clarithromycine & $\mu \mathrm{g} / \mathrm{kg}$ & $<5$ & NA & $<5$ & - & $<5$ & $<6$ & $<6,2$ & $<1$ & - & $<15$ & $<1,0$ & $<0$ & $<1$ & - & $<1$ \\
\hline
\end{tabular}




\title{
Addendum
}

\section{Her-analyse van zware metalen in effluenten van MVI's}

\author{
Aanleiding \\ Deze notitie betreft aanvullende metingen op de meetcampagne die werd uitgevoerd bij een \\ aantal mestverwerkingsinstallaties (MVI's) om beter zicht te krijgen op de aanwezigheid van \\ algemene klassieke parameters, zware metalen en voorzorgparameters (antibiotica, (resistente) \\ bacteriën, virussen en hormoonstoffen) in de te lozen effluenten en op de zuiveringsefficiëntie \\ van technieken die als Best Beschikbare Technieken (BBT) of gelijkwaardig beschouwd kunnen \\ worden. De gehalten aan zware metalen en voorzorgparameters in de effluenten van de MVI's \\ werden onder andere getoetst aan de grenswaarden die gelden voor risico's voor het aquatisch \\ leven in oppervlaktewater. \\ Doordat de rapportagegrenzen van de toegepaste analysemethode voor de meeste zware \\ metalen hoger waren dan de normwaarden (JG-MKN = jaargemiddelde concentratie voor \\ langdurige blootstelling) voor oppervlaktewater was toetsing van de effluenten aan deze \\ normwaarden echter niet goed mogelijk. Aanbevolen werd de analyse van zware metalen in de \\ effluent monsters nogmaals uit te voeren en wel met een analysemethode waarvoor lagere \\ rapportagegrenzen gelden zodat toetsing van de effluenten aan normwaarden voor zware \\ metalen in oppervlaktewater mogelijk wordt. \\ Het verzoek voor deze her-analyse werd gedaan tijdens de bespreking van het conceptrapport \\ van de eerdere meetcampagne met de werkgroep 'Harmonisatie lozingenbeleid \\ mestverwerkingsinstallaties' d.d. 5 nov 2020. \\ Doel \\ Deze her-analyse heeft als doel de gehalten aan zware metalen in reeds geanalyseerde monsters \\ van effluenten van 4 typen MVI's met een voldoend lage detectie- en rapportagegrens vast te \\ stellen, zodat deze getoetst kunnen worden aan de normwaarden voor zware metalen in \\ oppervlaktewater.
}

\section{Materiaal en methoden}

MVI's en geanalyseerde effluent monsters

In het eerder uitgevoerde meetprogramma werden de effluenten van 4 typen MVI's geanalyseerd op zware metalen. Van de totaal 24 effluent monsters kon van 21 monsters het resterende monstermateriaal worden teruggevonden. Eén monster afkomstig van een 00 installatie die betrokken was bij de monitoring van de pilot mineralenconcentraten is hieraan toegevoegd. Tabel A1 geeft de typen MVI's en het aantal effluentmonsters per type. De monsters van $\mathrm{OO}$ zijn afkomstig van 3 installaties, van biologische voorzuivering van 2 installaties en van MBR-UF en indampen van één installatie. 
Tabel A1 Typen MVI's en het aantal te analyseren effluentmonsters per type

\begin{tabular}{lcc} 
Type MVI & Mestsoort & Aantal monsters \\
\hline Omgekeerde osmose (OO) & Varkensdrijfmest & 12 \\
\hline Membraanbioreactor + UF (MBR-UF) & Varkensdrijfmest & 3 \\
\hline Indampen met en zonder OO/IW * & Varkensdrijfmest & 2 \\
\hline Biologische voorzuivering & Kalvergier & 5 \\
\hline
\end{tabular}

* IW = ionenwisselaar

Gemeten zware metalen en rapportagegrenzen

De meting van zware metalen werd uitgevoerd door Aqualysis in Zwolle, volgens NEN 6953

(ontsluiting conform NEN 6961 en NEN-EN-ISO 15587-1; meting conform NEN-EN-ISO 17294-2).

Tabel A2 vermeldt de gemeten metalen en de bijbehorende rapportagegrenzen.

Tabel A2 Gemeten metalen en rapportagegrenzen

\begin{tabular}{lc} 
Parameter & Rapportagegrens \\
& $(\mu g / I)$ \\
As & 0,3 \\
\hline $\mathrm{Ba}$ & 1 \\
\hline $\mathrm{Cd}$ & 0,03 \\
\hline $\mathrm{Co}$ & 0,2 \\
\hline $\mathrm{Cr}$ & 0,5 \\
\hline $\mathrm{Cu}$ & 0,5 \\
\hline $\mathrm{Hg}$ & 0,01 \\
\hline $\mathrm{Ni}$ & 0,5 \\
\hline $\mathrm{Pb}$ & 0,3 \\
\hline $\mathrm{U}$ & 0,05 \\
\hline $\mathrm{V}$ & 1 \\
\hline $\mathrm{Zn}$ & 3 \\
\hline $\mathrm{As}$ & 0,05 \\
\hline
\end{tabular}




\section{Resultaten}

Tabel A3 vermeldt de analyseresultaten. Per type MVI zijn gemiddelden, standaarddeviaties, maximum- en minimumwaarden gegeven. Eveneens is het aantal monsters aangegeven waarin het betreffende metaal is aangetroffen (en waarover het gemiddelde is berekend) en het totale aantal onderzochte monsters. Wanneer het metaal niet kon worden aangetoond tijdens de analyse is de detectiegrens vermeld.

Tabel A3 toont dat in alle effluenten één of meer metalen zijn aangetroffen. Van de enkele metalen, die in het effluent van OO (Ba en $\mathrm{Cu}$ ), indampen-1 ( $\mathrm{Cu}, \mathrm{V}$ en $\mathrm{Zn}$ ) en indampen-2 (V) zijn aangetroffen, liggen de gemeten concentraties onder de normwaarden voor oppervlaktewater. De 4 effluentmonsters van OO waarin metalen zijn gedetecteerd zijn van één MVI afkomstig. De effluenten van MBR-UF en biologische voorzuivering bevatten meerdere metalen in concentraties boven de normwaarden voor oppervlaktewater, t.w. As, Co, Cr, $\mathrm{Cu}, \mathrm{Ni}$, $\mathrm{V}$ en $\mathrm{Zn}$.

Het beeld dat deze metingen opleveren komt goed overeen met het algemene beeld zoals bijvoorbeeld bij de algemene parameters en de pathogenen, dat het effluent van MBR-UF hogere gehalten aan zware metalen bevat dan het effluent van OO. Dit was ook de verwachting gelet op het verschil in poriegrootte tussen UF- en OO-membranen. De eerdere vaststellingen (blz. 49/50 van het hoofdrapport) dat de concentraties van de aangetroffen zware metalen in de effluenten van de 4 MVI's alle boven de normwaarden voor oppervlaktewater liggen en dat die in het effluent van MBR-UF en OO met elkaar vergelijkbaar zijn, komt niet overeen met deze meetresultaten uit de her-analyse. De concentraties aan zware metalen liggen bij effluenten van 00 (en indampen) doorgaans onder de rapportagegrenzen van de analysemethoden en de normwaarden voor oppervlaktewater; voor effluenten MBR-UF (en biologische voorzuivering) veelal er boven.

Normwaarden voor zware metalen voor oppervlaktewater (jaargemiddelde concentratie voor langdurige blootstelling zijn gegeven in onderstaande tabel $^{3}$ :

\begin{tabular}{|c|c|c|}
\hline Parameter & $\begin{array}{l}\text { JG-MKN } \\
(\mu g / I)\end{array}$ & Opmerking \\
\hline As & 0,5 & \\
\hline $\mathrm{Ba}$ & 73 & \\
\hline $\mathrm{Cd}$ & 3,4 & \\
\hline Co & 0,2 & \\
\hline $\mathrm{Cr}$ & 3,4 & \\
\hline $\mathrm{Cu}$ & 2,4 & \\
\hline $\mathrm{Hg}$ & $0,08-0,25$ & Afhankelijk van waterhardheidsklasse \\
\hline $\mathrm{Ni}$ & 4 & \\
\hline $\mathrm{Pb}$ & 1,2 & \\
\hline Se & 0,052 & \\
\hline $\mathrm{U}$ & 0,17 & \\
\hline V & 3,5 & \\
\hline $\mathrm{Zn}$ & 7,8 & \\
\hline
\end{tabular}

\footnotetext{
${ }^{3}$ https://rvs.rivm.nI
} 
Tabel A3 Gemiddelden, standaarddeviaties, minimum- en maximumwaarden van zware metalen in effluentmonsters van 4 typen mestverwerkingsinstallaties (in $\mu g / l$ ).

\begin{tabular}{|c|c|c|c|c|c|c|c|c|c|c|c|c|c|c|c|c|c|c|c|c|c|c|c|c|c|}
\hline \multirow[t]{2}{*}{ Parameter } & \multicolumn{5}{|c|}{00} & \multicolumn{5}{|c|}{ MBR-UF } & \multicolumn{5}{|c|}{ Biologische voorzuivering } & \multicolumn{5}{|c|}{ Indampen-1* } & \multicolumn{5}{|c|}{ Indampen $-2 * *$} \\
\hline & Gem. & SD & Min & $\operatorname{Max}$ & $n * * *$ & Gem. & SD & Min & $\operatorname{Max}$ & $\mathrm{n}$ & Gem. & SD & Min & Max & $\mathrm{n}$ & Gem. & SD & Min & $\operatorname{Max}$ & $\mathrm{n}$ & Gem. & SD & Min & Max & $\bar{n}$ \\
\hline As & $<1$ & & & & $0 / 12$ & 4,1 & 1,2 & 2,7 & 4,9 & $3 / 3$ & 7,6 & 3,9 & 1,3 & 11 & $5 / 5$ & $<1$ & & & & $0 / 1$ & $<1$ & & & & $0 / 1$ \\
\hline $\mathrm{Ba}$ & 31 & 8 & 23 & 39 & $4 / 12$ & 18 & 5,5 & 12 & 22 & $3 / 3$ & 12 & 8,9 & 4,2 & 24 & $5 / 5$ & $<2$ & & & & $0 / 1$ & $<2$ & & & & $0 / 1$ \\
\hline $\mathrm{Cd}$ & $<0,1$ & & & & $0 / 12$ & $<0,1$ & & & & $0 / 3$ & 0,20 & 0,08 & 0,12 & 0,3 & $5 / 5$ & $<0,1$ & & & & $0 / 1$ & $<0,1$ & & & & $0 / 1$ \\
\hline Co & $<1$ & & & & $0 / 12$ & 16 & 6,2 & 11 & 23 & $3 / 3$ & 38 & 8,6 & 32 & 53 & $5 / 5$ & $<1$ & & & & $0 / 1$ & $<1$ & & & & $0 / 1$ \\
\hline $\mathrm{Cr}$ & $<2$ & & & & $0 / 12$ & 6,8 & 4,5 & 3,6 & 12 & $3 / 3$ & 4,9 & 0,96 & 4,2 & 6,0 & $3 / 5$ & $<2$ & & & & $0 / 1$ & $<2$ & & & & $0 / 1$ \\
\hline $\mathrm{Cu}$ & 2,0 & 1,0 & 1,1 & 3,7 & $4 / 12$ & 18 & 3,5 & 16 & 22 & $3 / 3$ & 122 & 56 & 52 & 180 & $5 / 5$ & 1,1 & - & - & - & $1 / 1$ & $<1$ & & & & $0 / 1$ \\
\hline $\mathrm{Hg}$ & $<0,05$ & & & & $0 / 12$ & $<0,05$ & & & & $0 / 3$ & $<0,05$ & & & & $0 / 5$ & $<0,05$ & & & & $0 / 1$ & $<0,05$ & & & & $0 / 1$ \\
\hline $\mathrm{Pb}$ & $<1$ & & & & $0 / 12$ & $<1$ & & & & $0 / 3$ & 1,1 & 0,21 & 1,0 & 1,3 & $2 / 5$ & $<1$ & & & & $0 / 1$ & $<1$ & & & & $0 / 1$ \\
\hline $\mathrm{Ni}$ & $<1$ & & & & $0 / 12$ & 64 & 29 & 41 & 96 & $3 / 3$ & 22 & 5,2 & 17 & 30 & $5 / 5$ & $<1$ & & & & $0 / 1$ & $<1$ & & & & $0 / 1$ \\
\hline $\mathrm{V}$ & $<1$ & & & & $0 / 12$ & 23 & 13 & 13 & 37 & $3 / 3$ & 12 & 5,4 & 5,4 & 18 & $4 / 5$ & 1,3 & - & - & - & $1 / 1$ & 1,3 & - & - & - & $1 / 1$ \\
\hline $\mathrm{Zn}$ & $<5$ & & & & $0 / 12$ & 44 & 10 & 36 & 55 & $3 / 3$ & 890 & 535 & 410 & 1600 & $5 / 5$ & 7,2 & - & - & - & $1 / 1$ & $<5$ & & & & $0 / 1$ \\
\hline
\end{tabular}

* betreft spuiwater vóór OO/IW

** betreft spuiwater ná OO/IW

*** aantal monsters waarin metaal is aangetroffen/aantal onderzochte monsters

Wanneer het metaal niet kon worden aangetoond is de detectiegrens vermeld $(<x, x)$ 


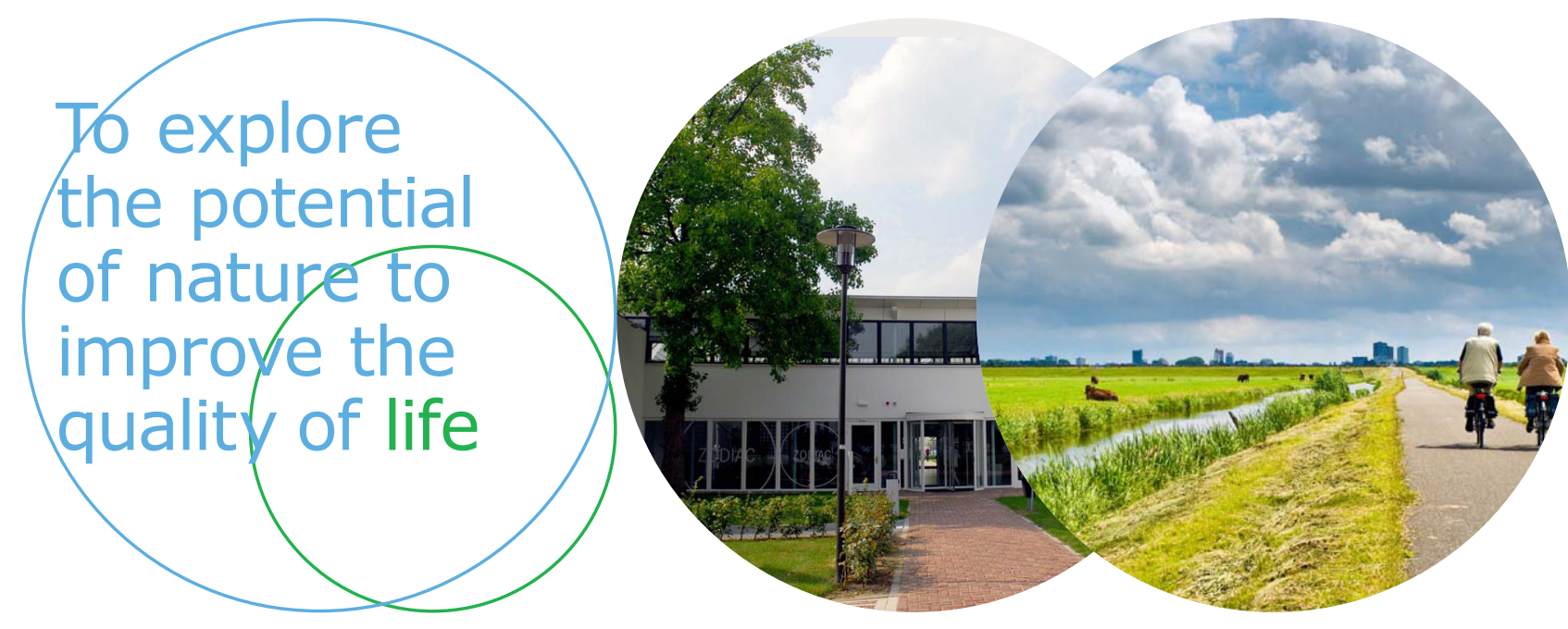

Wageningen Livestock Research Postbus 338

$6700 \mathrm{AH}$ Wageningen

T 0317483953

E info.livestockresearch@wur.nl www.wur.nl/livestock-research
Wageningen Livestock Research ontwikkelt kennis voor een zorgvuldige en renderende veehouderij, vertaalt deze naar praktijkgerichte oplossingen en innovaties, en zorgt voor doorstroming van deze kennis. Onze wetenschappelijke kennis op het gebied van veehouderijsystemen en van voeding, genetica, welzijn en milieu-impact van landbouwhuisdieren integreren we, samen met onze klanten, tot veehouderijconcepten voor de $21 \mathrm{e}$ eeuw.

De missie van Wageningen University \& Research is 'To explore the potential of nature to improve the quality of life'. Binnen Wageningen University \& Research bundelen 9 gespecialiseerde onderzoeksinstituten van Stichting Wageningen Research en Wageningen University hun krachten om bij te dragen aan de oplossing van belangrijke vragen in het domein van gezonde voeding en leefomgeving. Met ongeveer 30 vestigingen, 6.500 medewerkers en 10.000 studenten behoort Wageningen University \& Research wereldwijd tot de aansprekende kennisinstellingen binnen haar domein. De integrale benadering van de vraagstukken en de samenwerking tussen verschillende disciplines vormen het hart van de unieke Wageningen aanpak. 